POTENCIAL DOS COGUMELOS Lentinula edodes (SHIITAKE) E Agaricus blazei (COGUMELO-DO-SOL) NO CONTROLE DE DOENÇAS EM PLANTAS DE PEPINO, MARACUJÁ E TOMATE, E A PURIFICAÇÃO PARCIAL DE COMPOSTOS BIOLOGICAMENTE ATIVOS

\author{
ROBSON MARCELO DI PIERO
}

Tese apresentada à Escola Superior de Agricultura "Luiz de Queiroz", Universidade de São Paulo, para obtenção do título de Doutor em Agronomia, Área de Concentração: Fitopatologia.

PIRACICABA

Estado de São Paulo - Brasil

Julho - 2003 
POTENCIAL DOS COGUMELOS Lentinula edodes (SHITAKE) E Agaricus blazei (COGUMELO-DO-SOL) NO CONTROLE DE DOENÇAS EM PLANTAS DE PEPINO, MARACUJÁ E TOMATE, E A PURIFICAÇÃO PARCIAL DE COMPOSTOS BIOLOGICAMENTE ATIVOS

\section{ROBSON MARCELO DI PIERO}

Engenheiro Agrônomo

Orientador: Prof. Dr. SÉRGIO FLORENTINO PASCHOLATI

\footnotetext{
Tese apresentada à Escola Superior de Agricultura "Luiz de Queiroz”, Universidade de São Paulo, para obtenção do título de Doutor em Agronomia, Área de Concentração: Fitopatologia.
}

PIRACICABA

Estado de São Paulo - Brasil

Julho - 2003 


\section{Dados Internacionais de Catalogação na Publicação (CIP) DIVISÃO DE BIBLIOTECA E DOCUMENTAÇÃO - ESALQ/USP}

\section{Di Piero, Robson Marcelo}

Potencial dos cogumelosLentinula edodes (shiitake) e Agaric us blazei (cogume- lo-do-sol) no controle de doençasem plantas de pepino, maracujá e tomate, e a purific ação parcial de compostos biologicamente ativos/ Robson Marcelo Di Piero. - - Piracicaba, 2003.

157 p. : il.

Tese (doutorado) - Escola Superior de Agricultura Luiz de Queiroz, 2003. Bibliografia.

1. Antracnose 2. Cogumelos 3. Controle biológico 4. Endurecimentodos-frutos- -do-maracujazeiro 5. Mancha bacteriana 6. Pepino 7. Resistência induzida 8. Tomate I. Título 


\section{AGRADECIMENTOS}

Agradeço ao Prof. Dr. Sérgio Florentino Pascholati, pelas oportunidades, pela orientação e pelo convívio agradável estabelecido ao longo dos anos.

Aos amigos Dr. Nelson Arno Wulff e Dr. Quelmo Silva de Novaes, pela amizade e pelas sugestões na elaboração final da tese.

À amiga Nívea Maria Tonucci, pelo companheirismo, incentivo e auxílio durante a realização deste trabalho.

Ao Prof. Dr. Augusto Ferreira da Eira, pelo acolhimento junto ao grupo de pesquisa por ele liderado e pelo fornecimento dos cogumelos utilizados nesta tese.

A Zayame Vegette Pinto, pela ajuda nos experimentos de transmissão de vírus com vetores.

Obrigado também aos professores e demais colegas do Setor de Fitopatologia, pelos ensinamentos, pelos momentos agradáveis proporcionados e pelas informações úteis compartilhadas.

Aos funcionários Fernanda e Rodolfo, Heloísa, Sílvia, Marina, Jeferson, Edivaldo, Pedro Arthuso, Carmen e Sandra pela amizade e atenção dispensadas.

À Fundação de Amparo à Pesquisa do Estado de São Paulo (FAPESP) pelo apoio financeiro. 
A árvore tem esperança,

pois cortada poderá renascer,

e seus ramos continuam a crescer.

Ainda que envelheçam suas raízes na terra,

e seu tronco esteja amortecido no solo,

ao cheiro da água reverdece

e produz folhagem, como planta tenra.

(Jó, 14: 7-9)

Aos meu pais, Lídio e Maria de Lourdes,

E àminha irmã, Renata

Dedico 


\section{SUMÁRIO}

Página

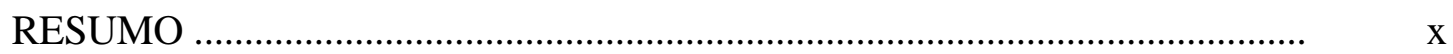

SUMMARY .............................................................................................. xii

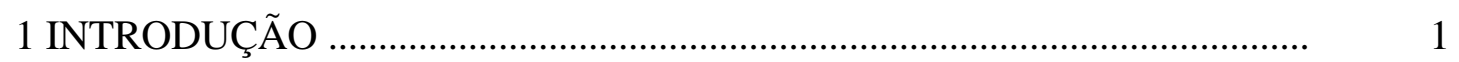

2 REVISÃO DE LITERATURA …............................................................ 4

$2.1 \mathrm{O}$ cogumelo shiitake (Lentinula edodes) ........................................................

2.1.1 Lentinula edodes: propriedades medicinais e compostos biologicamente ativos

2.1.2 Propriedades antibióticas do cogumelo shiitake

2.1.3 Efeito de L. edodes na proteção de plantas .................................................... 10

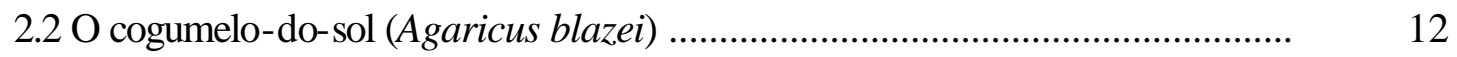

2.3 Isolados de L.edodes e de A. blazei utilizados nos experimentos ................... 14

2.4 Resistência sistêmica adquirida (RSA) e resistência sistêmica induzida (RSI)

2.4.1 Sinais para a indução de resistência ........................................................... 17

2.4.2 Mecanismos envolvidos na indução de resistência ........................................ 20

2.4.2.1 Lignificação e outras barreiras estruturais ............................................... 20

2.4.2.2 Proteínas relacionadas à patogênese (proteínas-RP) ................................ 22

2.4.3 Resistência induzida por microrganismos ................................................... 24

2.4.4 $\mathrm{O}$ ativador de plantas ASM ...................................................................... 26

2.5 Patossistemas estudados ....................................................................... 28

2.5.1 A antracnose do pepineiro causada por Colletotrichum lagenarium ............ 28

2.5.2 O endurecimento dos frutos do maracujazeiro provocado pelo PWV ......... 29

2.5.3 A mancha bacteriana do tomateiro provocada por Xanthomonas 
campestris pv. vesicatoria

3 INDUÇÃO DE RESISTÊNCIA EM PLANTAS DE PEPINO CONTRA Colletotrichum lagenarium PELA APLICAÇÃO DE EXTRATOS DE BASIDIOCARPOS DE Lentinula edodes (cogumelo shiitake) E DE Agaricus blazei (cogumelo-do-sol) .............................................................................

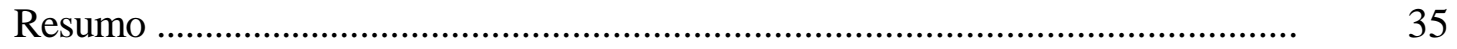

Summary …................................................................................................... 36

3.1 Introdução ............................................................................................... 37

3.2 Material e Métodos ............................................................................... 40

3.2.1 Obtenção dos preparados de Lentinula edodes e de Agaricus blazei ..... $\quad 40$

3.2.2 Planta e patógeno ................................................................................ 40

3.2.3 Proteção de plantas de pepino em casa de vegetação utilizando extratos dos basidiocarpos de A. blazei e de L. edodes ............................................. 41

3.2.4 Efeito in vitro dos extratos de basidiocarpos dos cogumelos sobre o crescimento micelial e a germinação de esporos de C. lagenarium .............. 41

3.2.5 Determinação da atividade de proteínas relacionadas à patogênese em

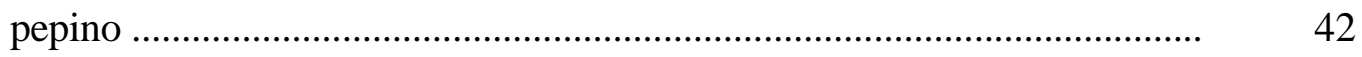

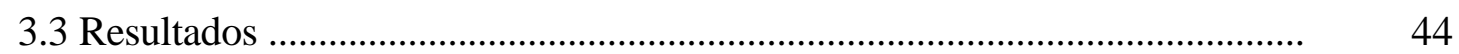

3.3.1 Proteção de plantas de pepino em casa de vegetação utilizando extratos aquosos de basidiocarpos de A. blazei e de L. edodes ................................. 44

3.3.2 Efeito in vitro dos extratos de basidiocarpos sobre $C$. lagenarium .............. 51

3.3.3 Determinação da atividade de proteínas relacionadas à patogênese em plantas de pepino

3.3.4 Efeito dos extratos aquosos de basidiocarpos de A. blazei e L. edodes no desenvolvimento das plantas de pepino ....................................................... 58

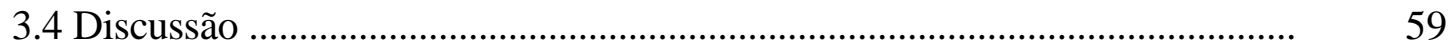

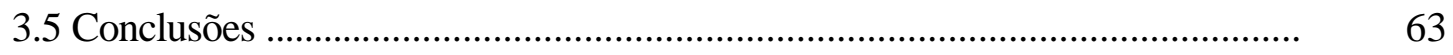


4 PURIFICAÇÃO PARCIAL DE ELICITORES DE PEROXIDASES EM

PLÂNTULAS DE PEPINO, ISOLADOS A PARTIR DE Lentinula edodes, COM ATIVIDADE PROTETORA CONTRA Colletotrichum lagenarium ...... $\quad 64$

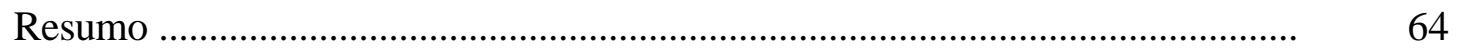

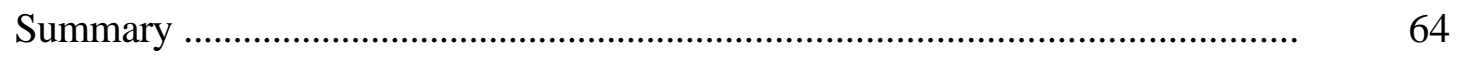

4.1 Introdução .............................................................................................. $\quad 65$

4.2 Material e Métodos ............................................................................................ 68

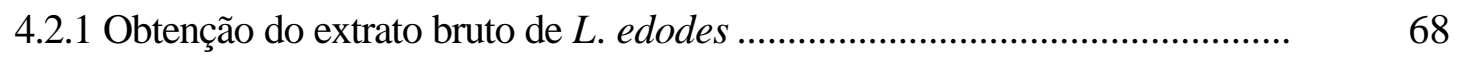

4.2.2 Precipitação fracionada do extrato aquoso de basidiocarpos de L.edodes .. $\quad 69$

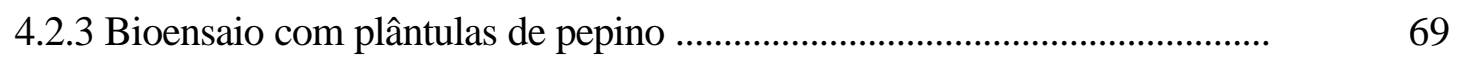

4.2.4 Separação do precipitado relativo à saturação de 40-80\% (p40-80)

utilizando-se cromatografia .................................................................. $\quad 70$

4.2.5 Determinação da atividade de peroxidases em cotilédones de pepino .......... 71

4.2.6 Análise das frações biologicamente ativas através de eletroforese desnaturante (SDS-PAGE) ............................................................... 72

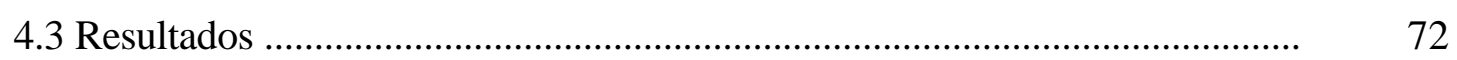

4.3.1 Atividade protetora dos precipitados, obtidos a partir do extrato aquoso de basidiocarpos de L.edodes, em plântulas de pepino contra C. lagenarium $\quad 72$

4.3.2 Separação das frações por cromatografias de troca iônica ............................ 75

4.3.3 Determinação da atividade de peroxidases em cotilédones de pepino ......... $\quad 80$

4.3.4 Análise das frações biologicamente ativas através de eletroforese desnaturante (SDS-PAGE) ……............................................................ 80

4.4 Discussão ............................................................................................... 81

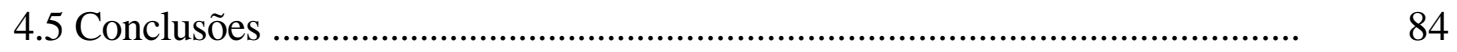

5 EFEITO DOS COGUMELOS Lentinula edodes E Agaricus blazei NA PROTEÇÃO DE PLANTAS DE MARACUJÁ CONTRA O Passion fruit woodiness virus (PWV) ........................................................................... 85

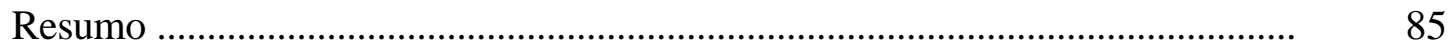

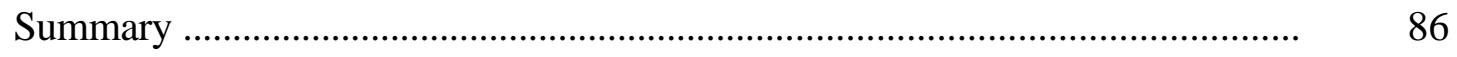

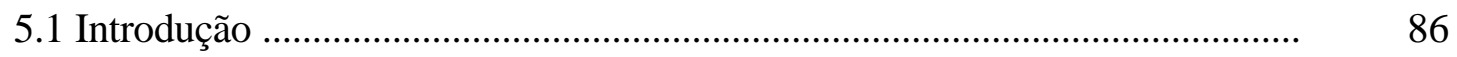


5.2 Material e Métodos

5.2.1 Obtenção dos preparados de Lentinula edodes (shiitake) e de Agaricus blazei (cogumelo-do-sol)

5.2.2 Planta e patógeno

5.2.3 Proteção de plantas de maracujá inoculadas mecanicamente com o PWV ..

5.2.4 Realização do teste serológico DAS-ELISA indireto

5.2.5 Efeito do ambiente e do intervalo de tempo entre tratamento-inoculação sobre a proteção de plantas de maracujá contra o PWV

5.2.6 Transmissão do PWV para plantas de maracujá, utilizando-se o vetor Myzus persicae

5.2.7 Efeito dos extratos dos cogumelos na infectividade do PWV

5.2.8 Proteção sistêmica de C. quinoa contra o PWV

5.3 Resultados

5.3.1 Proteção de plantas de maracujá inoculadas mecanicamente com o PWV ..

5.3.2 Confirmação da ausência de efeito sistêmico dos extratos dos cogumelos contra o PWV em maracujazeiro

5.3.3 Efeito do nitrogênio, do ambiente e do intervalo de tempo entre tratamento-inoculação sobre a proteção de plantas de maracujá contra o PWV

5.3.4 Transmissão do PWV por M. persicae

5.3.5 Efeito dos extratos dos cogumelos na infectividade do PWV e na proteção sistêmica de C. quinoa

5.4 Discussão

5.5 Conclusões

6 PROTEÇÃO DE PLANTAS DE TOMATE CONTRA Xanthomonas vesicatoria UTILIZANDO EXTRATOS DOS COGUMELOS Lentinula edodes e Agaricus blazei

Resumo

Summary

6.1 Introdução 
6.2 Material e Métodos

6.2.1 Obtenção dos preparados de Lentinula edodes (shiitake) e de Agaricus blazei (cogumelo-do-sol)

6.2.2 Planta e patógeno

6.2.3 Proteção de plantas de tomate em casa de vegetação

6.2.4 Efeito in vitro de L. edodes e A. blazei sobre $X$. vesicatoria

6.2.5 Determinação da atividade de proteínas relacionadas à patogênese em plantas de tomate

6.3 Resultados

6.3.1 Proteção de plantas de tomate contra Xanthomonas vesicatoria

6.3.2 Efeito in vitro de L. edodes e A. blazei sobre X. vesicatoria

6.3.3 Determinação da atividade de proteínas relacionadas à patogênese em plantas de tomate

6.4 Discussão

6.5 Conclusões 


\title{
POTENCIAL DOS COGUMELOS Lentinula edodes (SHIITAKE) E Agaricus blazei (COGUMELO-DO-SOL) NO CONTROLE DE DOENÇAS EM PLANTAS DE PEPINO, MARACUJÁ E TOMATE, E A PURIFICAÇÃO PARCIAL DE COMPOSTOS BIOLOGICAMENTE ATIVOS
}

\author{
Autor: ROBSON MARCELO DI PIERO \\ Orientador: Prof. Dr. SÉRGIO FLORENTINO PASCHOLATI
}

\section{RESUMO}

Os cogumelos Lentinula edodes (shiitake) e Agaricus blazei (cogumelo-do-sol) apresentam substâncias no corpo de frutificação (basidiocarpo) e no micélio com atividades antibióticas e imuno-regulatórias, havendo uma série de relatos sobre a atuação das mesmas no controle de doenças em animais. Em vegetais, não há informações sobre o efeito protetor do cogumelo-do-sol contra fitopatógenos. No caso de shiitake, embora pouco numerosos, os estudos mostraram o potencial do cogumelo para o controle de doenças de plantas, tais como a murcha bacteriana do tomateiro, a murcha de feijão-lima, além de doenças fúngicas em sorgo e da bacteriose do maracujazeiro. Os objetivos do presente trabalho foram o de avaliar o efeito de diferentes preparações obtidas a partir de L. edodes e de A. blazei em patossistemas agrícolas, visando o controle de moléstias de interesse econômico como a antracnose do pepineiro, a mancha bacteriana do tomateiro e o endurecimento dos frutos do maracujazeiro. Obtida a proteção, os estudos buscaram elucidar o modo de ação das preparações de interesse, bem como purificá-las parcialmente, na tentativa de se 
concentrar o princípio ativo. Em plantas de pepino, extratos aquosos de basidiocarpos, obtidos a partir de diferentes isolados dos cogumelos, reduziram a severidade da antracnose, na dependência da concentração do extrato. Os extratos não afetaram adversamente o agente causal da doença, Colletotrichum lagenarium, mas provocaram o acúmulo de peroxidases e quitinases nas folhas tratadas e sistemicamente. Utilizando-se precipitação fracionada do extrato aquoso bruto de basidiocarpos de shiitake com sulfato de amônio e cromatografia de troca aniônica, obteve-se uma fração de proteínas, apresentando massa molecular de 29 a $35 \mathrm{kDa}$, com atividade elicitora de peroxidases em cotilédones de pepino. Em plantas de tomate, o isolado ABL 99/28 de A. blazei foi quem, em média, conferiu maior proteção contra Xanthomonas vesicatoria, a qual foi dependente das concentrações de extrato do cogumelo e de células bacterianas empregadas nos testes. Novamente, o extrato aquoso de basidiocarpos do isolado efetivo não atuou diretamente sobre o patógeno, mas desencadeou o aumento na atividade de $\beta$ 1,3-glucanases nas folhas tratadas, sugerindo que o mecanismo de ação em pepineiro e tomateiro envolveu a indução de resistência. Já no caso do maracujazeiro, os extratos de basidiocarpos, obtidos a partir de diferentes isolados de ambos os cogumelos, protegeram localmente plantas inoculadas mecanicamente com o Passion fruit woodiness vírus (PWV), por reduzirem a infectividade viral, o que foi comprovado em testes conduzidos com Chenopodium quinoa, hospedeiro de lesão local do vírus. Entretanto, não houve proteção sistêmica em plantas de maracujá, nos experimentos de inoculação mecânica, reduzindo as possibilidades do uso dos cogumelos para o controle dessa virose no campo. De forma geral, os resultados mostraram que os cogumelos $L$. edodes e A. blazei apresentam compostos que ativam as respostas de defesa em plantas e podem auxiliar no controle de doenças vegetais, dependendo da natureza do agente causal. 


\title{
POTENTIAL OF THE MUSHROOMS Lentinula edodes (SHIITAKE) AND Agaricus blazei (ROYAL MUSHROOM) IN THE CONTROL OF DISEASES IN CUCUMBER, PASSION FRUIT AND TOMATO PLANTS, AND THE PARTIAL PURIFICATION OF BIOLOGICALLY ACTIVE COMPOUNDS
}

\author{
Author: ROBSON MARCELO DI PIERO \\ Adviser: Prof. Dr. SÉRGIO FLORENTINO PASCHOLATI
}

\section{SUMMARY}

The mushrooms Lentinula edodes and Agaricus blazei have substances in the fruiting body and in the mycelia exhibiting antibiotic activity and others able to stimulate the immune system in animals. There are many reports about the performance of these substances in the control of animal diseases. In vegetables, there are no information about the protecting effect of the royal mushroom against plant pathogens. In the case of shiitake, although few in number, the studies showed the potential of the mushroom for the control of plant diseases, such as tomato bacterial wilt, sorghum leave spots and bacterial disease of the passion fruit plant. The objectives of the present work were to evaluate the effect of different preparations from L. edodes and A. blazei to control the diseases cucumber anthracnose, tomato bacterial spot and passion fruit woodiness. As the protection of the plants was obtained, the studies tried to elucidate the way of action of the preparations, as well as partially purify them, in an attempt to concentrate the active compound. In cucumber plants, fruiting body aqueous extracts, from different mushroom isolates, reduced anthracnose severity, depending upon the 
extract concentration. The extracts did not affect adversely the disease causal agent, Colletotrichum lagenarium, but induced the peroxidase and quitinase accumulation in the treated leaves and systemically. By using fractional precipitation of the shiitake fruiting body aqueous extracts with ammonium sulfate, and anion exchange chromatography, a protein fraction exhibiting molecular mass around 29 to $35 \mathrm{kDa}$ and peroxidase elicitor activity in cucumber cotyledons was obtained. In tomato plants, the isolate ABL 99/28 of A. blazei was the one that, on average, gave higher protection against Xanthomonas vesicatoria, which was dependent upon the extract and bacterial cell concentrations. Again, the fruiting body aqueous extract of ABL 99/28 did not act directly onto the pathogen, but it caused an increase in $\beta$-1,3-glucanase activity in the treated leaves, suggesting that the mushroom action in cucumber and tomato plants involved the induced resistance. On the other hand, the fruiting body extracts, obtained from different isolates of both mushrooms, protected locally passion fruit plants inoculated mechanically with the Passion fruit woodiness virus (PWV) by reducing viral infectivity, what was proven through tests carried out with Chenopodium quinoa, a PWV local lesion host. However, there was no systemic protection in passion fruit plants against the virus in the experiments involving mechanical inoculation, reducing the possibilities of the mushroom use for the PWV control in the field. In a general way, the results showed that the mushrooms L. edodes and A. blazei have substances that activate the plant defense mechanisms and they show some potential in the control of vegetable diseases, depending upon the nature of the pathogen. 


\section{INTRODUÇÃO}

A atividade agrícola é governada por aspectos de ordem técnica, econômica, política e social. Do ponto de vista técnico, o objetivo maior é o aumento na produtividade, o que somente pode ser alcançado mediante o manejo adequado dos fatores de produção: clima, variedade, adubação, tratos culturais e fitossanitários.

Existe uma demanda crescente de alimentos no mundo e para atender a essa demanda, a agricultura moderna conta com uma série de avanços nos diferentes setores, tais como mecanização, melhoramento de cultivares, síntese de moléculas químicas mais eficientes para o controle de pragas e doenças, entre outros.

Considerando-se os cuidados fitossanitários, o controle das doenças bióticas pode representar o fator decisivo na produção agrícola, dependendo da espécie vegetal em questão, do ano agrícola e do manejo cultural, e por isso se reveste de extrema importância.

O grande avanço no controle de doenças de plantas ocorreu com a descoberta de produtos com ação sistêmica, que, graças às suas propriedades, apresentam alta eficiência em sua tarefa. Por outro lado, o uso indiscriminado desses produtos trouxe uma série de problemas para os agricultores, consumidores e para o meio ambiente. Além do controle químico, outra estratégia de manejo muito utilizada para controlar doenças em plantas é o uso de um ou poucos genes para resistência a raças específicas de fitopatógenos. No entanto, há ampla evidência da falta de durabilidade nessa estratégia, pois mudanças rápidas nas raças são comuns nos campos, conduzindo a uma pesquisa sem fim para novos genes. Por estas razões, o fenômeno da indução de resistência tem atraído a atenção de cientistas e da iniciativa privada.

Resistência induzida é um termo geral que define o processo ativo de resistência dependente de barreiras físicas e/ou químicas da planta hospedeira, ativado por agentes 
bióticos ou abióticos, os chamados agentes indutores. Entre os indutores bióticos, podemos citar patógenos ativos ou inativados, linhagens não patogênicas e metabólitos microbianos. A resistência induzida opera através dos mesmos mecanismos que normalmente funcionam para restringir o crescimento e a disseminação do patógeno.

Atualmente, há indutores de resistência disponíveis comercialmente. Estes não irão substituir os fungicidas tradicionais, mas o uso em conjunto ou alternado pode conduzir a uma redução no número de aplicações dos agrotóxicos. Adicionalmente, a ativação simultânea de diversos mecanismos de defesa, durante a expressão da resistência sistêmica adquirida (RSA), diminui o risco da seleção de linhagens insensíveis à RSA, outro sério problema com respeito a muitos fungicidas que apresentam um único sítio de atuação contra os fitopatógenos. Mais um aspecto positivo da resistência induzida é que ela se vale do potencial genético da planta para que sejam ativados os mecanismos de defesa, sem alterações no genoma, permitindo que materiais de interesse agronômico suscetíveis continuem a ser plantados no campo.

Entre os candidatos a atuarem como indutores bióticos de resistência estão os cogumelos Lentinula edodes (Berk.) Pegler (cogumelo shiitake) e Agaricus blazei (Murril) ss. Heinem (cogumelo-do-sol). Muitos estudos dentro da área médica mostraram resultados positivos da utilização desses cogumelos no combate a patógenos humanos, e também na ativação do sistema imunológico e na melhora de problemas de saúde como o colesterol, a asma e a úlcera. Uma das substâncias caracterizadas, isolada do basidiocarpo de shiitake por extração aquosa, é a lentinana, a qual mostra-se capaz de recuperar ou aumentar a resposta das células hospedeiras a substâncias biologicamente ativas, por estimular a maturação, diferenciação ou proliferação de células envolvidas nos mecanismos de defesa, aumentando a resistência do hospedeiro contra vários tipos de câncer e doenças infecciosas (Chihara, 1993).

Os poucos trabalhos que foram realizados na área agrícola envolveram o uso do cogumelo shiitake, e mostraram que o mesmo apresenta potencial para o controle de doenças de plantas, através da utilização dos lixiviados do micélio, extratos do basidiocarpo e da própria lentinana purificada (Pacumbaba et al., 1999; Piccinin, 2000), sem esclarecimentos sobre o modo de ação do cogumelo. Dessa forma, o objetivo desse 
trabalho foi avaliar o efeito de diferentes preparações obtidas a partir de L. edodes e de A. blazei em patossistemas agrícolas, visando o controle de moléstias de interesse econômico como a mancha bacteriana do tomateiro, o endurecimento dos frutos do maracujazeiro, e a antracnose do pepineiro. Obtida a proteção, os estudos buscaram elucidar o modo de ação das preparações de interesse, bem como purificá-las parcialmente, na tentativa de se concentrar o princípio ativo, o qual pode servir de base para a obtenção de moléculas de interesse fitopatológico. 


\section{REVISÃO DE LITERATURA}

\subsection{O cogumelo shiitake (Lentinula edodes)}

\subsubsection{L.edodes: propriedades medicinais e compostos biologicamente ativos}

Os basidiomicetos são fungos de micélio septado, que se reproduzem por esporos exógenos (basidiosporos) formados sobre uma hifa especial denominada basídia. Geralmente, grampos de conexão são formados no micélio vegetativo para manter a sua condição binucleada (Moore-Landecker, 1982).

L. edodes, conhecido como cogumelo shiitake, é um basidiomiceto cujo corpo de frutificação é amplamente utilizado na culinária asiática e cujo consumo vem sendo difundido atualmente a nível mundial, incluindo o Brasil. O shiitake é a segunda mais importante espécie de cogumelo comestível cultivada no mundo (Przybylowicz \& Donoghue, 1990). Atualmente, o shiitake é produzido no Japão, Taiwan, República Popular da China, Tailândia, Coréia e Malásia, além dos países ocidentais (Leatham, 1985), inclusive o Brasil (Eira \& Montini, 1997). A produção mundial de shiitake em 1997 foi aproximadamente 144.000 toneladas, em termos de cogumelo seco, sendo a China responsável por 70\% dessa produção (Van Nieuwenhuijzen, 1998).

O padrão de restrição do DNA ribossomal confirma que o shiitake faz parte da Ordem Agaricales e do gênero Lentinula, e suporta a separação de Lentinula edodes a partir de Lentinus, gênero ao qual o cogumelo shiitake era incluído (Molina et al., 1992). O fungo pode ser cultivado em troncos de árvores como o eucalipto, carvalho, mangueira e abacateiro, ou em cultivo axênico, e tem atraído a atenção de pesquisadores por apresentar qualidades nutricionais, medicinais e terapêuticas comprovadas cientificamente. 
O cogumelo shiitake é fonte de proteínas de boa qualidade (10-17\% da matéria seca), carboidratos (a maior parte consistindo de fibras dietéticas), vitaminas e minerais. Além disso, é pobre em lipídios e os ácidos graxos são predominantemente insaturados. Apesar de conter todos os aminoácidos essenciais, L. edodes apresenta baixos níveis de metionina e cistina (Breene, 1990).

Várias propriedades fisiológicas têm sido influenciadas por cogumelos, tais como a imunoproteção, a manutenção de homeostase, a regulação do bioritmo, a prevenção de doenças coronárias e cancerígenas. Confirma-se também que cogumelos produzem substâncias efetivas para a redução do colesterol e da pressão sanguiíneos, além de substâncias com ação antitrombótica e hipoglicêmica (Wasser \& Weis, 1999).

Estudos conduzidos sob condições controladas mostraram que os princípios ativos presentes no cogumelo shiitake podem exercer efeitos totalmente diferentes dependendo da dose, da rota de administração e da condição do hospedeiro. É também aparente que tipos similares de efeitos podem ser elicitados por moléculas estruturalmente diferentes. A seguir, os principais componentes de L. edodes já caracterizados são descritos.

Dentre os compostos ativadores do sistema imunológico encontrados em $L$. edodes, destaca-se a lentinana. Trata-se de uma $\beta$-D-glucana com alta massa molecular (aproximadamente $5 \times 10^{5} \mathrm{Da}$ ) e configuração helicoidal, isolada a partir do extrato aquoso do corpo de frutificação do fungo (Chihara et al., 1969). A fórmula molecular da lentinana é $\left(\mathrm{C}_{6} \mathrm{H}_{10} \mathrm{O}_{5}\right)$ n.

O composto lentinana apresentou proeminente atividade contra tumores alogênicos, tais como sarcoma 180, sinérgicos e autóctones, e preveniu oncogêneses química e viral. $\mathrm{O}$ polissacarídeo não é tóxico às células tumorais, mas inibe $\mathrm{o}$ crescimento do tumor pela ativação do sistema imune, ou seja, a $\beta$-D-glucana se liga à superfície de linfócitos ou a proteínas específicas do soro, que ativarão células efetoras tais como macrófagos, células T-helper, células natural killer, proporcionando o aumento na produção de anticorpos, interleucinas e interferon (Mizuno, 1995a). De forma semelhante, o efeito protetor de lentinana em animais contra infecções causadas pelas bactérias Escherichia coli, Pseudomonas aureaginosa e Klebsiella pneumonia 
ocorreu devido ao aumento da imunoproteção e não pela ação direta do composto sobre esses microrganismos (Jong \& Birmingham, 1993).

Miyakoshi et al. (1984) relataram que lentinana pode inibir câncer em humanos. A ativação das células T-killer por uma cultura de linfócitos foi acelerada somente quando células responsivas foram misturadas com um número sub-ótimo de células estimuladoras e lentinana. O nível de interferon na circulação sanguínea de pacientes com câncer foi aumentado seguindo-se a administração de lentinana.

O valor da DL50 de lentinana em ratos é superior a $250 \mathrm{mg} / \mathrm{Kg}$ (administração intra-venosa) e acima de $2.500 \mathrm{mg} / \mathrm{Kg}$ (administração oral). Doses superiores produziram cianose, convulsões e até morte (Jong \& Birmingham, 1993).

Além de lentinana, vários compostos ativadores do sistema imunológico têm sido isolados de cogumelos medicinais. A partir do micélio de L. edodes é obtido um $\alpha$ mananapeptídeo denominado KS-2, após extração com água quente e precipitação etanólica. KS-2 contém os aminoácidos serina, treonina, alanina e prolina e também apresenta atividade antitumoral relacionada à ativação de macrófagos. Quando administrado oral ou intra-peritonealmente para ratos infectados com o vírus da influenza, KS-2 apresentou efeitos preventivo e curativo através de sua atividade indutora de interferon (Suzuki et al., 1979).

Uma glicoproteína contendo galactose, xilose, arabinose, vitaminas do complexo B e ergosterol, conhecida como LEM ("Lentinula edodes mycelia"), é obtida após a maceração do micélio de shiitake junto com o meio sólido no qual o fungo cresceu vegetativamente por 3 a 4 meses, a $22{ }^{\circ} \mathrm{C}$. Posteriormente, o macerado é incubado por 60 h a $50{ }^{\circ} \mathrm{C}$, na presença de enzimas de ocorrência natural no micélio do shiitake, e o resíduo passa por extração aquosa a $60{ }^{\circ} \mathrm{C}$ e é liofilizado, resultando num pó castanho denominado LEM. Alguns dos compostos de LEM modularam respostas imunológicas em animais, por ativação de macrófagos, enquanto outros apresentaram caráter antibiótico (Sugano et al., 1982).

Trabalhando com LEM, pesquisadores têm caracterizado outras substâncias imunoprotetoras, tais como LAP e EP3. LAP é um precipitado obtido a partir de uma solução aquosa de LEM pela adição de quatro volumes de etanol, enquanto EP3 trata-se 
de um complexo composto por $80 \%$ de lignina, $10 \%$ de carboidratos e $10 \%$ de proteínas, obtido pelo fracionamento de LEM, e que apresenta uma lignina solúvel em água contendo grupos carboxil como substância ativa (Suzuki et al., 1990). O rendimento de LEM é 6-7 g/Kg de meio sólido cultivado e o de LAP, 30g/100g de LEM.

Um composto denominado eritadenina, obtido a partir de extrato etanólico (80\%) de basidiocarpos, apresenta ação hipocolesterolêmica, provavelmente por alterar $\mathrm{o}$ metabolismo fosfolipídico hepático. A dosagem de $50 \mathrm{mg}$ desse composto por quilo de massa corpórea é suficiente para diminuir a concentração de colesterol plasmático em ratos (Sugiyama et al., 1995). Estudos sobre o modo de ação mostraram que eritadenina não inibe a biossíntese do colesterol, mas acelera a excreção do colesterol ingerido e a decomposição dos seus metabólitos (Mizuno, 1995a). Em testes conduzidos com humanos, Suzuki \& Ohshima (1974) reportaram diminuição na pressão sanguiínea e no colesterol do soro em mulheres alimentadas com shiitake fresco ou seco.

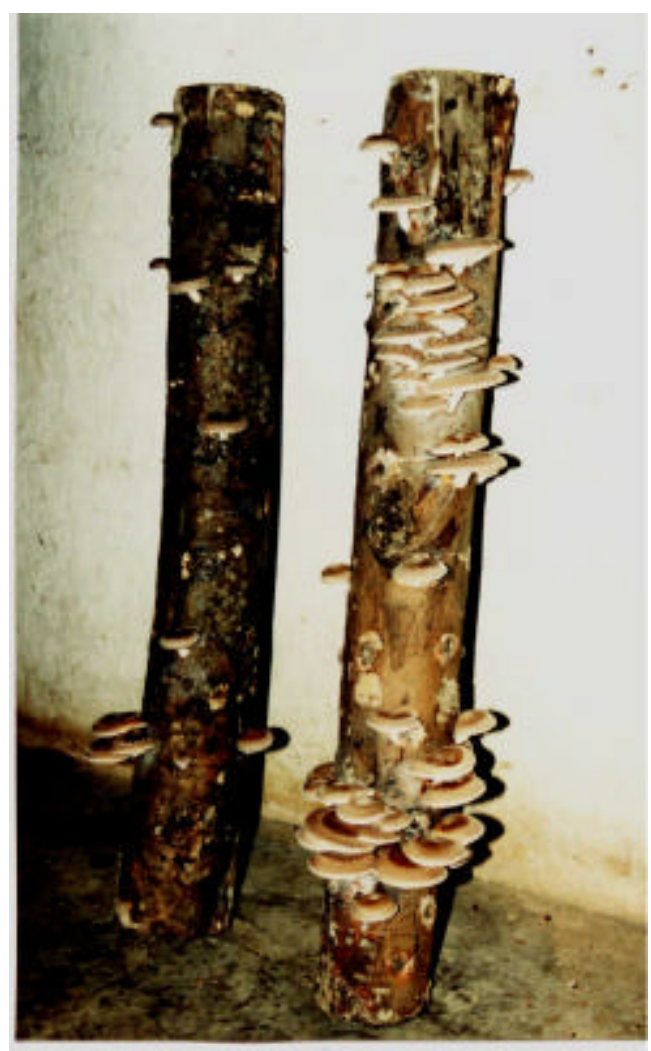

Figura 1 - Basidiocarpos de Lentinula edodes (cogumelo shiitake) produzid os em toras de eucalipto. Escala $1: 10$ 


\subsubsection{Propriedades antibióticas do cogumelo shiitake}

São inúmeros os trabalhos que relacionam compostos de ação antiviral produzidos pelo fungo. O complexo lignina-proteína-carboidratos, EP3, apresentou atividade contra o vírus da imunodeficiência humana Human immunodeficiency vírus HIV), sendo a lignina solubilizada em água o princípio ativo presente no composto (Suzuki et al., 1990).

Lentinana usada em combinação com azidotimidina (AZT) suprimiram a expressão superficial do HIV sobre células-T em maior intensidade do que o AZT sozinho. LEM também é útil no tratamento da AIDS, inibindo a infecção do HIV em células-T humanas cultivadas e potencializando o efeito do AZT contra replicação viral in vitro (Tochikura et al., 1988).

Em adição, lentinana mostrou atividade antiviral em camundongos contra vírus como o VSV (Vesicular stomatitis virus), o vírus da encefalite, o Abelson vírus e estimulou resistência não-específica contra infecções virais respiratórias. Eritadenina, o composto que afeta o metabolismo do colesterol, também apresenta propriedades antivirais (Wasser \& Weis, 1999).

Compostos inibidores de infecção de vírus de planta ocorrem ainda nos extratos de corpos de frutificação de fungos basidiomicetos. Kobayashi et al. (1987) encontraram uma nova substância em corpos de frutificação de $L$. edodes que apresentou atividade inibitória à infecção do vírus do mosaico do fumo (Tobacco mosaic virus - TMV). O novo inibidor foi purificado por fracionamento com DEAE-celulose, filtração em gel com Sephadex G-75 e cromatografia de coluna com CM-Toyopearl 650M, e mostrou ser uma proteína simples denominada de proteína do corpo de frutificação (PCF). Quase $1 \mathrm{mg}$ de PCF foi obtida a partir de $1.000 \mathrm{~g}$ de corpos de frutificação. Estudos realizados posteriormente por Hiramatsu et al. (1987) mostraram que a PCF foi estável entre pH 4 e 9, e a temperaturas inferiores a $60{ }^{\circ} \mathrm{C}$, mas foi inativada por diálise contra água deionizada. A concentração de PCF para uma inibição de 50\% da infectividade do TMV em fumo Nicotiana tabacum var. xanthi foi de 6,3 ppm, enquanto que 16,3 ppm inibiu $50 \%$ da infectividade do ácido nucléico do TMV, sugerindo que a inibição não ocorreu no processo de desnudamento viral. Análise da mistura PCF+TMV em microscopia 
eletrônica mostrou que não houve agregação de partículas virais. PCF também não mostrou atividade para hidrólise de RNA e o mecanismo de ação da proteína (PCF) permanece não esclarecido.

A produção de substâncias por L. edodes que atuam contra bactérias por antibiose tem sido explorada. Bianco (1981) obteve atividade antibiótica contra Staphylococcus aureus e Bacillus subtilis utilizando cortinelina, um composto isolado de L. edodes. Um outro composto antibacteriano formado por um álcool $\beta$-fenetil e lentinamicina foi isolado a partir de cultura líquida de micélio (Komemushi et al., 1996).

Extratos clorofórmicos do basidiocarpo de shiitake apresentaram atividade bactericida contra células vegetativas e células de resistência de Streptococcus mutans, o principal agente causal de cáries dentárias e contra Prevotella intermedia, provocador de doença periodontal em adultos. Por sua vez, substâncias solúveis em água ou em acetato de etila mostraram-se bacteriostáticas. Os principais componentes dos extratos clorofórmico e aquoso podem ser lentionina e lentinana, respectivamente (Hirasawa et al., 1999). Lentionina é um composto sulfatado, detectado tanto no basidiocarpo como na biomassa micelial produzida em cultura submersa e apresenta forte atividade antibacteriana e antifúngica (Lelik et al., 1997; Hatvani, 2001).

O lixiviado micelial de L. edodes inibiu significativamente o crescimento de todas as espécies de bactérias fitopatogênicas testadas por Pacumbaba et al. (1999), incluindo Pseudomonas syringae pv. glycinea, P. syringae pv. tabaci, Xanthomonas campestris pv. glycines, Erwinia amylovora, X. campestris pv. campestris, Ralstonia solanacearum e Curtobacterium flaccumfaciens pv. flaccumfaciens, bem como demonstrou-se a inibição do crescimento de bactérias que afetam alimentos ou animais: B. cereus, Escherichia coli, Listeria monocytogenes, Salmonella typhimurium e Staphylococcus aureus. A zona de inibição causada pelo exsudado micelial variou de 14 a 17 mm de diâmetro para as bactérias fitopatogênicas e de 20 a 30 mm de diâmetro para as demais.

O extrato do píleo (EP) de L. edodes mostrourse bacteriostático, enquanto que o extrato da estipe (EE) e o filtrado do crescimento micelial (FCM) foram bactericidas sobre Xanthomonas campestris pv. passiflorae, quando incorporados em água e não 
aquecidos. O aquecimento prévio do EP provocou uma perda total na sua atividade, enquanto o EE tornou-se bacteriostático após o aquecimento (Piccinin, 2000).

O cogumelo shiitake também produz compostos que atuam contra fungos. Extratos obtidos a partir do crescimento micelial de L. edodes, utilizados a 100, 200 e $300 \mu \mathrm{L} / \mathrm{mL}$ BDA, inibiram o desenvolvimento in vitro dos fungos filamentosos Helminthosporium sp. e Fusarium solani, agentes causais da helmintosporiose do trigo e da síndrome da morte súbita em soja, respectivamente. Não houve diferenças significativas entre as dosagens utilizadas. Por sua vez, o agente causal da seca das hastes e das vagens em soja, Phomopsis sojae, teve o seu crescimento micelial inibido apenas pela maior dosagem utilizada (Sasaki, 1997).

Maki (1999) reportou que a liberação de substâncias inibitórias a Candida albicans para o substrato de crescimento de L. edodes é um caráter amplamente difundido a nível intraespecífico, e está relacionado às condições de cultivo do cogumelo. A maioria das linhagens de L. edodes teve melhor crescimento micelial a 25$28{ }^{\circ} \mathrm{C}$, mas foi $16{ }^{\circ} \mathrm{C}$ a temperatura de crescimento que proporcionou maior atividade fungistática contra a levedura. A atividade antibiótica do cogumelo desidratado e transformado em pó sobre a levedura C. albicans não foi reduzida comparado ao cogumelo fresco, o que é vantajoso, pois cogumelos desidratados constituem uma alternativa bastante adequada para a preservação a longo prazo dos mesmos em condições ideais para consumo (Paccola, 1997).

Piccinin (2000) mostrou que o filtrado obtido a partir do crescimento vegetativo de L. edodes, bem como os extratos obtidos a partir do píleo e da estipe do cogumelo, reduziram significativamente o crescimento micelial de Exserohilum turcicum e Colletotrichum sublineolum a partir da concentração de $1 \%$ (v/v) no meio de cultivo. A $2 \%$, as preparações reduziram a esporulação dos patógenos. A atividade dos filtrados sobre o desenvolvimento micelial foi fungistática e termolábil.

\subsubsection{Efeito de L.edodes na proteção de plantas}

Alguns estudos já foram conduzidos com L. edodes dentro da Fitopatologia. A infecção foliar provocada pelo TMV em plantas de fumo foi fortemente inibida (acima 
de $90 \%$ de inibição) quando a proteína do corpo de frutificação de L. edodes (PCF) foi aplicada 1 dia antes do vírus. Porém, a aplicação da proteína $6 \mathrm{~h}$ ou mais após a inoculação das folhas com o TMV não apresentou redução na infectividade viral, mostrando que a PCF teve um efeito apenas protetor e não curativo sobre a virose (Hiramatsu et al., 1987).

A redução da infectividade do TMV também foi demonstrada por Piccinin (2000), pela aplicação de lentinana ou do extrato de basidiocarpo de shiitake, numa concentração de $2 \%(\mathrm{v} / \mathrm{v}), 2$ dias antes da inoculação da cultivar TNN de fumo (hospedeiro de lesão local) com o vírus. Por outro lado, essas preparações não protegeram a cultivar Turkish, que apresenta infecção viral sistêmica. Esse autor ainda mostrou que o extrato da estipe e o filtrado do crescimento micelial de L. edodes protegeram maracujá contra X. passiflorae, e que o extrato de basidiocarpo protegeu sorgo contra $C$. sublineolum.

O lixiviado micelial de $L$. edodes preveniu a murcha bacteriana do tomateiro provocada por R. solanacearum e murcha de feijão-lima provocada por $C$. flaccumfaciens pv. flaccumfaciens, quando aplicado em vasos contendo uma mistura de vermiculita e pro-mix (1:1), previamente infestados com a bactéria patogênica à cultura em questão (Pacumbaba et al., 1999).

Os resultados obtidos contra o TMV e contra as bactérias causadoras de murcha podem refletir a ação de substâncias produzidas pelo shiitake atuando diretamente sobre os fitopatógenos, mais do que na planta. Por outro lado, lentinana (obtida a partir do extrato aquoso do corpo de frutificação de L. edodes) não apresentou atividade direta contra E. turcicum, C. sublineolum e contra X. campestris pv. passiflorae em testes realizados in vitro, mas protegeu plantas de sorgo contra os fungos fitopatogênicos considerados e maracujá contra a fitobactéria (Piccinin, 2000), demonstrando que além de produzir substâncias antibióticas, o cogumelo shiitake pode sintetizar compostos ativadores do sistema de defesa vegetal. 


\subsection{O cogumelo-do-sol (Agaricus blazei)}

A. blazei, um cogumelo nativo do Brasil, tem sido amplamente consumido em diferentes partes do mundo devido às suas propriedades medicinais. $\mathrm{O}$ cogumelo vem sendo cultivado comercialmente no Brasil desde o início da década de 90 e a maior produção encontra-se no estado de São Paulo, onde o cultivo principal é feito nas épocas de primavera e verão (Braga et al., 1998). No Japão, a produção anual varia de 100 a 300 toneladas de basidiocarpo seco (Takaku et al., 2001).

Segundo Mizuno et al. (1990), o basidiocarpo de A. blazei apresenta 40-45\% de proteínas, 38-45\% de carboidratos, 6-8\% de fibras, 5-7\% de minerais e 3-5\% de gordura, valores baseados em relação à matéria-seca. Contém ainda as vitaminas B1, B2 e niacina e teores elevados de potássio e cálcio. Além das propriedades nutricionais, A. blazei é utilizado por aproximadamente 500.000 pessoas para prevenção do câncer ou como um adjuvante no tratamento com drogas quimioterápicas, após a remoção de um tumor maligno (Takaku et al., 2001). Segundo Eguchi et al. (1999), o extrato aquoso de basidiocarpo de A. blazei pode ser um alimento útil para o tratamento preventivo e curativo de disfunções renais.

Vários compostos de interesse medicinal já foram caracterizados (Mizuno, 1995b). Compostos antitumorais incluem polissacarídeos, complexos proteínapolissacarídeos, esteróides, presentes tanto no basidiocarpo como no micélio. Kawagishi et al. (1990) obtiveram um complexo gluco-protéico, com um alto conteúdo dos aminoácidos alanina e leucina, apresentando atividade antitumoral. $\mathrm{O}$ efeito, caracterizado pela inibição do crescimento de sarcoma-180 implantado em camundongos, ocorreu provavelmente devido às propriedades imuno-regulatórias do complexo. Mizuno et al. (1990) demostraram efeito similar a partir de polissacarídeos obtidos a partir do extrato aquoso do basidiocarpo, destancando-se o complexo 1,6- e 1,4- $\alpha$-glucana e o complexo 1,6- e 1,3- $\beta$-glucana como os componentes principais de diferentes polissacarídeos. Por sua vez, os polissacarídeos isolados a partir de extrato aquoso do micélio de A. blazei, que apresentaram atividade antitumoral, foram diferentes dos polissacarídeos antitumorais isolados do basidiocarpo do cogumelo (Mizuno et al., 1999). 
O complexo 1,6- e 1,4- $\alpha$-glucana também estimulou a síntese de linfócitos quando administrado em camundongos normais, sugerindo que polissacarídeos de $A$. blazei podem ser importantes para o tratamento preventivo contra o câncer (Mizuno et al., 1998). Outro indicativo de que o efeito antitumoral de A. blazei ocorre por estimular o sistema imunológico do hospedeiro veio com o trabalho de Nakajima et al. (2002), onde a expressão de RNA mensageiro de interleucinas foi aumentada pelo extrato de $A$. blazei, tanto nos macrófagos peritoneais como nas células do baço. Isto sugere que o extrato pode estimular macrófagos e células- $\mathrm{T}$ a liberarem interleucinas, resultando no aumento da produção de anticorpos.

Ergosterol, purificado a partir da fração lipídica do cogumelo, é outra substância com atividade antitumoral. A inibição direta da angiogênese provavelmente seja a responsável pelo modo de ação do ergosterol (Takaku et al., 2001).

Atividade antimutagênica em Salmonella foi encontrada em extratos hexânicos do basidiocarpo e atribuída ao ácido linoléico (Osaki et al., 1994). Por sua vez, os extratos aquosos mostraram-se antimutagênicos quando testados em células V79 de hamster chinês (Menoli et al., 2001).

Em termos do efeito antibiótico por parte de A. blazei, poucos relatos foram feitos. Investigando a atividade antiviral do cogumelo-do-sol, Sorimachi et al. (2001) mostraram que frações, obtidas pela precipitação etanólica a 44 e a $50 \%$ do extrato aquoso micelial, inibiram completamente a ocorrência de alterações morfológicas induzidas pelo Western equine encephalitis virus (WEEV) em células VER0-317 derivadas do rim de macaco, enquanto que as frações correspondentes, obtidas do basidiocarpo, foram pouco efetivas. Osaki et al. (1994) encontraram atividade antibacteriana nos extratos clorofórmicos e metanólicos do basidiocarpo de A. blazei. A substância isolada foi ativa contra Salmonella typhimurium e foi identificada como ácido octadecadienóico. 


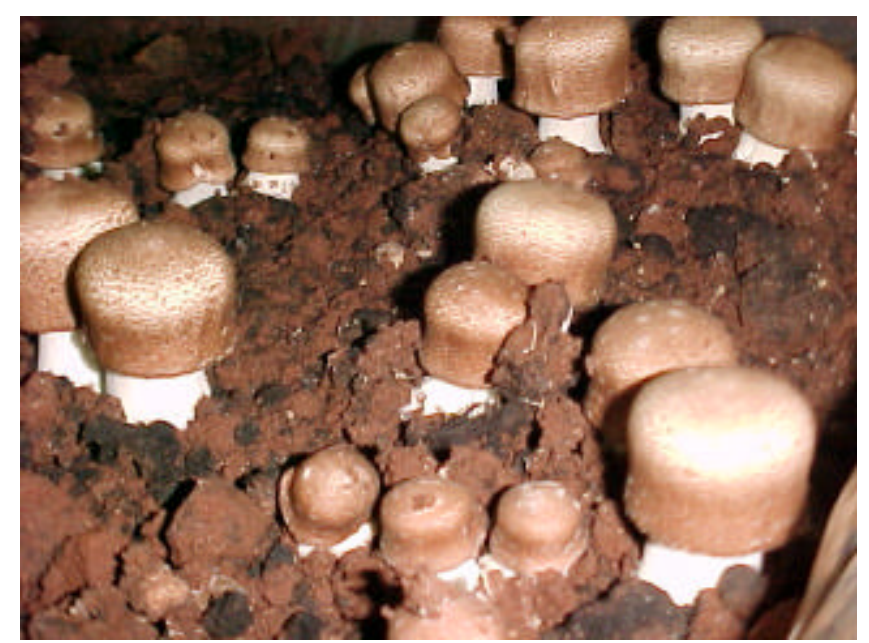

Figura 2 - Basidiocarpos de Agaricus blazei produzidos a partir de substrato axênico. Escala $1: 2$

\subsection{Isolados de L. edodes e de A. blazei utilizados nos experime ntos}

Os cogumelos foram produzidos no Departamento de Produção Vegetal (Módulo de Cogumelos), da Faculdade de Ciências Agrárias/UNESP/Botucatu, sob responsabilidade do Prof. Dr. Augusto Ferreira da Eira.

Os basidiocarpos dos isolados de shiitake utilizados para a elaboração dessa tese foram obtidos após o cultivo do cogumelo em toras de eucalipto das espécies Eucaliptus grandis e E. saligna, em local sombreado, no campo. As principais etapas desse cultivo envolveram: i) produção de "inóculo" (crescimento vegetativo) em meio sintético; ii) "inoculação" das toras de eucalipto; iii) incubação; iv) choque térmico e hídrico para induzir os primórdios de basidiocarpo; v) colheita e processamento dos basidiocarpos.

Já os basidiocarpos dos isolados de A. blazei foram provenientes de cultivos axênicos, realizados em substratos mantidos no interior de câmaras de produção, onde os fatores ambientais são totalmente controlados. As etapas de cultivo envolveram: i) preparo do substrato de cultivo (bagaço de cana, capim de gramíneas, farelo de soja, enriquecido com sais minerais) através da compostagem e da pasteurização; ii) adição de micélio do cogumelo junto ao substrato; iii) colonização do substrato; iv) cobertura do substrato com turfa Santa Catarina, para induzir a formação dos primórdios de basidiocarpo; v) colheita e processamento dos basidiocarpos. 
Análises de isoenzimas e de DNA revelaram que todos os isolados de L. edodes utilizados são diferentes entre si, confirmando-se também a hipótese de que o reisolamento de LE 95/01, ou seja o isolado LE 96/22, sofreu hibridações no campo ou outras variações genéticas (Teixeira, 2000). As principais características dos isolados de L. edodes são apresentadas na Tabela 1.

Tabela 1. Características dos isolados de Lentinula edodes utilizados nos experimentos

Característica Isolados

LE 95/01* LE 96/17 LE 96/22** LE JAB-K

Procedência Londrina/PR Israel Botucatu/SP Jaboticabal/SP

Clima ideal

$\begin{array}{llll}\mathrm{p} / \text { cultivo } & \text { Inverno } & \text { Verão } & \text { Inverno }\end{array}$

Tamanho do

basidiocarpo $\quad 5 \mathrm{a} 7 \mathrm{~cm} \quad 5 \mathrm{a} 7 \mathrm{~cm} \quad>9 \mathrm{~cm}$

Estipe $\quad$ Espessa e longa Espessa Espessa e curta

*O número antes da barra trata-se do ano de isolamento (no caso, 1995)

**O isolado LE 96/22 é um reisolamento, realizado em Botucatu/SP, de LE 95/01

No caso de A. blazei, , baseando-se em dados de RAPD, os isolados empregados nessa tese apresentam pouca variabilidade genética entre si (Colauto et al., 2002).

\subsection{Resistência sistêmica adquirida (RSA) e resistência sistêmica induzida (RSI)}

As plantas apresentam um potencial para reagir a um invasor ou a indutores e desencadear respostas de defesa locais e sistêmicas. Após o reconhecimento do patógeno ou de um indutor pela planta, é desencadeada uma cascata de eventos iniciais, associados com a transdução de sinais intracelulares, que incluem mudanças em fluxos iônicos ao longo da membrana plasmática, eventos de fosforilação de várias proteínas, 
geração de espécies ativas de oxigênio, com posterior ativação dos mecanismos de defesa (Métraux, 2001).

Um aspecto comum da maior parte dos tratamentos indutores parece ser o desenvolvimento local de necrose (Sticher et al., 1997). A produção de um sinal liberado a partir da folha infectada por um patógeno que provoca necrose e a translocação deste sinal para outras partes da planta, induzindo reações de defesa, é o que explica a chamada resistência sistêmica adquirida (RSA). Mecanismos induzidos de defesa incluem modificações da parede celular, produção de fitoalexinas, síntese de proteínas relacionadas à patogênese (proteínas-RP) e a ativação da reação de hipersensibilidade (Van Loon, 1997; Hammerschmidt, 1999).

RSA tem sido descrita em várias espécies de plantas e apresenta características como a expressão contra um amplo espectro de microrganismos, necessidade de um tempo após o tratamento indutor para que ocorra o estabelecimento do fenômeno, duração da proteção por um longo período e atuação através de um processo multicomponente. Em algumas espécies, RSA foi demonstrada ser transmissível via enxertia e ser dependente das condições ambientais.

Um interessante caso de resistência adquirida foi descrito utilizando-se rizobactérias promotoras de crescimento vegetal (RPCV) colonizando a rizosfera. RPCV aplicadas ao solo, permanecem localizadas na superfície radicular e podem induzir resistência nas folhas ou caule. Esta forma de resistência onde o indutor não provoca sintomas como necrose no local de tratamento, mas que protege sistemicamente as plantas, é comumente denominada resistência sistêmica induzida - RSI (Pieterse et al., 1996).

Em Arabidopsis, RSI por Pseudomonas fluorescens foi ativa contra o patógeno fúngico radicular Fusarium oxysporum f. sp. raphani, contra o patógeno foliar Peronospora parasitica (um oomiceto), e contra as bactérias causadoras de manchas foliares Xanthomonas campestris pv. campestris e Pseudomonas syringae pv. tomato, indicando que a exemplo do que ocorre com RSA, RSI também apresenta um amplo espectro de atuação (Van Wees et al., 1997). As principais diferenças entre RSA e RSI serão descritas no próximo ítem. 
O conhecimento da indução de resistência promete ser útil na elaboração de novas estratégias para a proteção das culturas. Novos indutores químicos de resistência já foram desenvolvidos comercialmente com potencial aplicação no mercado de cereais, hortaliças e frutíferas.

\subsubsection{Sinais para a indução de resistência}

Os níveis endógenos de ácido salicílico (AS) aumentaram local e sistemicamente em plantas de fumo inoculadas com o TMV e no floema de plantas de pepino infectadas antes da expressão da RSA e foram correlacionados com a indução de proteínas relacionadas à patogênese (proteínas-RP). Além disso, aplicação exógena de AS em várias plantas ativou os mesmos genes RSA que são expressos seguindo a indução biológica da RSA (Ward et al., 1991). Essas observações têm conduzido à idéia que o AS poderia ser um sinal endógeno responsável pelo desencadeamento da resistência.

A importância do AS no caminho de transdução de sinal da RSA foi posteriormente documentada usando plantas de fumo e Arabidopsis engenheiradas para superexpressar salicilato-hidroxilase, uma enzima de Pseudomonas putida, codificada pelo gene $N a h G$ e envolvida na conversão de AS em catecol, um composto não indutor de RSA. Em plantas de fumo transformadas com o gene $N a h G$ e inoculadas com o TMV, os níveis de AS são baixos e a RSA é bloqueada, indicando que o AS é requerido para a ocorrência da RSA (Gaffney et al., 1993).

Experimentos de enxertia com plantas de fumo selvagem ou expressando o gene $N a h G$ revelaram que o AS não é o sinal sistêmico para RSA. Vernooij et al. (1994) encontraram que a inoculação com o TMV de porta-enxerto expressando $N a h G$ (incapaz de acumular AS) induziu RSA na copa de maneira semelhante a que ocorre quando o porta-enxerto selvagem é induzido. Por outro lado, copas que expressam NahG perderam a habilidade de serem induzidas à resistência, independente do tipo de portaenxerto utilizado, fortalecendo o conceito que o AS tem que estar presente para o sinal sistêmico ser traduzido junto à expressão gênica e àresistência.

O modo de ação do AS na RSA não é totalmente esclarecido. Diversos trabalhos têm mostrado que o AS em altas concentrações $(1 \mathrm{mM})$ pode se ligar a enzimas 
contendo ferro, como catalase, ascorbato peroxidase ou asconitase em virtude de sua afinidade pelo elemento. Essa ligação conduziria à inibição das enzimas e ao conseqüente acúmulo de peróxido de hidrogênio $\left(\mathrm{H}_{2} \mathrm{O}_{2}\right)$, o qual reforçaria o pico oxidativo gerado após a infecção e desencadearia respostas de defesa (Baker \& Orlandi, 1995). Relatam-se, também, efeito antimicrobiano e inibição da síntese de ácido jasmônico por parte do AS, ações cuja relevância para a RSA ainda são questionadas.

O AS ainda pode ativar a expressão de um gene que é dependente de NIM1/NIP1, uma proteína com regiões similares aos domínios ankirina (envolvidas em interações proteína-proteína) e com outros motivos que sugerem que NIM1/NIP1 se trata de um fator de transcrição. NIM1/NIP1 já foi mostrada ser requerida para indução de resistência e postula-se que o AS seja o seu ativador (Maleck \& Lawton, 1998). NPR1 é uma outra proteína, que sob ação do AS, pode atuar como fator de transcrição, levando à ativação de genes relacionados à resistência (Zhang et al., 1999).

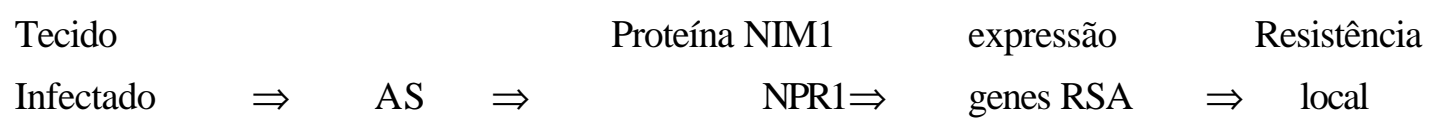

Sinal sistêmico

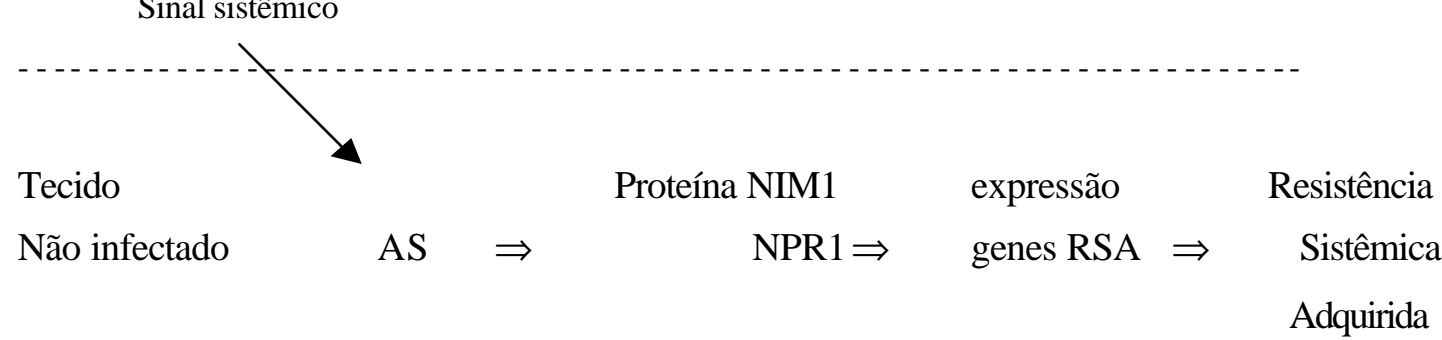

Figura 3 - Transdução de sinal na RSA. AS = ácido salicílico, NIM e NPR1 = prováveis fatores de transcrição, RSA = resistência sistêmica adquirida (Adaptado de Ryals et al., 1996)

Portanto, normalmente, o AS é colocado como um intermediário no caminho de transdução de sinais que leva a aumento na resistência vegetal. Por outro lado, a resistência sistêmica pode ser induzida por um caminho independente de AS. 
Outras moléculas envolvidas nas interações plantas-patógenos são os jasmonatos e seus ésteres. Baixas concentrações de ácido jasmônico (AJ) induzem inibidores de proteinases, tionina, osmotina, proteínas de parede celular ricas em hidroxiprolina, e enzimas envolvidas nas reações de defesa, como chalcona sintase e fenilalanina amônialiase. Uma indicação adicional suportando o envolvimento do AJ na resistência vem a partir das observações que o ferimento de plantas ou o tratamento de culturas celulares com elicitores fúngicos conduzem a aumentos na biossíntese de AJ (Gundlach et al., 1992).

O tratamento de plantas de Arabidopsis thaliana com metil jasmonato induziu resistência e levou ao acúmulo de uma defensina antifúngica, mas não da proteína RP-1, enquanto a aplicação de AS provocou o acúmulo de RP-1, mas não de defensina. Estes resultados, bem como os de experimentos usando mutantes de Arabidopsis afetados em diferentes passos do caminho de transdução de sinais, sugerem a presença de dois caminhos diferentes, ambos induzíveis por patógenos, mas um ocorrendo via AS e expressão de proteínas-RP, o outro via jasmonatos e acúmulo de defensinas (Penninckx et al., 1996).

A exemplo dos jasmonatos, etileno, um hormônio vegetal volátil derivado a partir da metionina, está envolvido em vários processos fisiológicos. Etileno é produzido após ferimento ou infecção com patógenos, bem como por tratamento com elicitores, além da sua aplicação desencadear mecanismos de defesa nas plantas, o que sugere a ligação do etileno com RSA (Boller, 1990). Embora alguns estudos tenham apontado a síntese vegetal de etileno mais como sintoma do que como causa de reações de defesa (Mauch et al., 1984), outros mostraram que o etileno é um intermediário necessário, junto com o AJ, para regular a expressão de genes de defesa (O’Donnel et al., 1996).

AJ e etileno são sinais para resistência em um caminho que é independente do AS e do acúmulo de proteínas-RP, e onde os indutores típicos são as rizobactérias promotoras de crescimento vegetal. Esse caminho, conhecido como Resistência Sistêmica Induzida (RSI), a exemplo de RSA, é dependente da proteína NPR1, mostrando que o AS não é o único ativador dessa proteína. Evidentemente, NPR1 regula 
de forma diferencial a expressão de genes relacionados à RSI ou à RSA, dependendo de como o caminho foi previamente ativado (Pieterse et al., 2001).

Parece também haver alguma interação entre os caminhos dependente de AS e o dependente de AJ, desde que o AS inibe a biossíntese de jasmonatos nas plantas (Doares et al., 1995), e o AJ, por sua vez, também pode inibir a ação de salicilatos. Mas nem sempre ocorre antagonismos entre os caminhos, pois já foi demonstrado em A thaliana que a ativação simultânea de ambos os caminhos resultou em um efeito aditivo no nível de proteção induzida contra Psudomonas syringae pv. tomato (Pst) (Van Wess đal., 2000).

Se por um lado, ácido salicílico, ácido jasmônico e etileno são sinais envolvidos nos diferentes caminhos de transdução que levam à resistência, por outro, a natureza química do sinal sistêmico permanece incerta (Métraux, 2001).

Tabela 2. Comparação da Resistência Sistêmica Adquirida (RSA) com a Resistência Sistêmica Induzida (RSI)

RSA Patógenos necrotizantes

Compostos químicos

Molécula(s)- sinal

Genes marcadores*
Ácido salicílico

Genes RSA (proteínas-RP)

\section{RSI}

Rizobactérias, ferimentos

Ácido jasmônico, etileno

Ácido jasmônico/etileno

Defensinas, tioninas

Inibidores de proteases

*Genes marcadores são genes cuja expressão é altamente correlacionada com a manutenção de resistência (adaptado de Maleck \& Lawton, 1998)

\subsubsection{Mecanismos envolvidos na indução de resistência}

\subsubsection{Lignificação e outras barreiras estruturais}

Lignificação tem sido observada em muitas espécies vegetais após a infecção com um organismo patogênico e é apontada como um importante mecanismo para a resistência induzida. Lignina é formada pela polimerização de precursores produzidos no 
caminho dos fenilpropanóides (Vance et al., 1980). A enzima fenilalanina amônia-liase (FAL) atua no primeiro passo desse caminho, convertendo fenilalanina para ácido cinâmico, e fornece precursores para a lignina e para vários metabólitos secundários derivados dos fenilpropanóides envolvidos na resistência. FAL é induzida em muitas reações de resistência e após o tratamento com vários indutores/elicitores de defesa (Davis \& Ausubel, 1989).

A contribuição da lignificação para a resistência pode ocorrer de diferentes maneiras. Em primeiro lugar, a incorporação de lignina junto à parede celular vegetal torna-a mais resistente à degradação por enzimas secretadas pelo patógeno invasor. Paredes celulares lignificadas poderiam também constituir uma barreira, evitando o movimento de nutrientes até o patógeno. Os próprios precursores de lignina podem exercer um efeito tóxico sobre o patógeno ou conduzir à lignificação de estruturas do patógeno (Hammerschmidt \& Kuc, 1982).

O fortalecimento da parede celular vegetal sob infecção pode ocorrer ainda pela deposição de materiais, como calose, silício e outros materiais fluorescentes, como também pelo entrecruzamento de glicoproteínas ricas em hidroxiprolina, catalizado por peroxidases (Bradley et al., 1992). Todas essas alterações na estrutura da parede celular vegetal após infecção podem contribuir para resistência, seja por bloquear diretamente o ingresso do patógeno ou por atrasar o processo de penetração, permitindo à planta ativar outros mecanismos de defesa.

Alguns exemplos ilustram a participação das barreiras estruturais na resistência induzida. Em fumo, indução de resistência sistêmica contra Peronospora tabacina por inoculação prévia com o TMV está associada a uma série de mudanças sistêmicas nas paredes celulares de plantas de fumo imunizadas, tais como a ativação de duas peroxidases aniônicas localizadas nos espaços intercelulares, o acúmulo de glicoproteínas ricas em hidroxiprolina, e o acúmulo de quatro proteínas solúveis em sais nas paredes celulares, não relacionadas a proteínas-RP (Ye et al., 1992).

Plantas de tomate susceptíveis a Fusarium oxysporum f. sp. radicids-lycopersici, tratadas com o indutor químico acibenzolar S-metil (ASM), reagiram mais rapidamente ao patógeno, através da formação de barreiras estruturais no sítio de infecção. A 
colonização pelo patógeno, restrita à epiderme e ao córtex externo das raízes, foi associada ao fortalecimento da parede celular pela rápida deposição de calose e de compostos fenólicos nas aposições de parede formadas nas plantas tratadas com ASM, fornecendo forte proteção contra a invasão vascular e contra toxinas e enzimas líticas produzidas por Fusarium (Benhamou \& Bélanger, 1998).

\subsubsection{Proteínas relacionadas à patogênese (proteínas-RP)}

Proteínas-RP têm sido definidas como proteínas vegetais que se acumulam após o ataque por um patógeno ou situações relacionadas, como o tratamento com certos químicos e outros tipos de estresses (Van Loon et al., 1994).

Essas proteínas foram descritas primeiramente em folhas de fumo infectadas com o TMV, na década de 70 (Van Loon \& Van Kammen, 1970). A maioria delas se acumula no espaço extracelular, entrando em contato direto com o patógeno invasor, ou dentro do vacúolo, necessitando portanto de uma descompartimentalização celular para exercerem um efeito nas reações de defesa.

Proteínas-RP têm sido identificadas em, ao menos, nove famílias de plantas, sendo melhor caracterizadas as que ocorrem em fumo e tomate. Sabe-se que elas compreendem quatro famílias de quitinases (RP-3, -4, -8, e -11), uma de $\beta-1,3-$ glucanases (RP-2), uma de inibidores de proteinases (RP-6), uma de peroxidase (RP-9), a família RP-1 com propriedades bioquímicas desconhecidas, a família RP-5 semelhante à taumatina, e a família RP-10, relacionada ao alérgeno presente em vidoeiro Betv-1. Nem todas as famílias são representadas em qualquer espécie vegetal, mas cada família pode compreender diversos membros (Van Loon, 1997).

Algumas das proteínas-RP possuem atividade antipatogênica, pela ação nas paredes celulares do patógeno invasor. Quitinases e glucanases hidrolizam respectivamente quitina e glucana, polímeros que são componentes principais da parede celular de muitos fungos. Bactérias podem ser inibidas pela família RP-8 de quitinases, que também possui atividade de lisozima (Linthorst, 1991). As proteínas-RP, atuando em componentes dos fitopatógenos, ainda liberam moléculas que podem atuar como elicitores de outras respostas de defesa (Keen \& Yoshikawa, 1983). 
A importância das proteínas-RP na defesa pode ser estudada utilizando-se plantas transgênicas expressando os genes correspondentes. A maioria desses estudos foi realizado em plantas de fumo, onde demonstrou-se, em experimentos independentes, que a superexpressão de RP-1, de uma $\beta$-1,3-glucanase de soja ou de uma quitinase de feijão aumentou a resistência contra Peronospora tabacina e Phytophthora parasitica var nicotianae (Alexander et al., 1993), contra Phytophthora megasperma e Alternaria alternata (Yoshikawa et al., 1993), e contra Rhizoctonia solani (Broglie et al., 1991), respectivamente.

A indução de proteínas-RP tem sido ligada a infecções necrotizantes conduzindo à RSA, e tem sido tomada como um marcador do estado induzido (Ward et al., 1991). Os termos encontrados na literatura "proteínas RSA" ou "genes RSA" referem-se a muitas das proteínas-RP ou aos seus genes, pelo fato dessas proteínas serem induzidas sistemicamente em uma série de espécies vegetais, onde se demonstrou algum envolvimento das mesmas com a resistência adquirida. Um estudo com tomate, por exemplo, mostrou um aumento de duas vezes na atividade de quitinases, glucanases e outras proteínas-RP nas folhas superiores após infecção das inferiores com Phytophthora infestans. O aumento sistêmico nas proteínas foi correlacionado com indução sistêmica de resistência contra o fitopatógeno (Binder et al., 1989).

A identidade e os níveis de expressão relativos dos genes RSA variam entre as diferentes espécies de plantas. Por exemplo, em pepino, RP-1 acídica é fracamente expressa, enquanto em fumo e em Arabidopsis, RP-1 acídica é a proteína predominantemente relacionada à RSA. Tais diferenças específicas podem refletir evoluções diferentes ou limitações do melhoramento vegetal, que selecionaram para a resposta RSA mais efetiva contra o conjunto particular de patógenos para os quais uma espécie individual está sujeita (Kessmann et al., 1994).

Um tratamento biótico ou abiótico de uma planta pode induzir ao acúmulo sistêmico de proteínas-RP mesmo antes do contato da planta com o patógeno desafiador. Em contraste, a lignificação da parede celular só é detectada após a inoculação com o patógeno. No caso da lignificação, o sinal sistêmico gerado após o tratamento indutor tem condicionado os tecidos da planta (mesmo os que não receberam diretamente o 
indutor) a responderem mais rapidamente à infecção em relação aos tecidos das plantas não induzidas (Sticher et al., 1997).

Muitas vezes, a ndução de uma mesma proteína-RP ocorre a partir de diferentes situações, como o ataque por um patógeno ou um estresse salino (Kadder, 1997). Isto reforça a importância das proteínas-RP como proteínas de estresse, com funções que excedem o seu envolvimento nas interações planta-patógeno. Por outro lado, existem indutores de resistência que não ativam as proteínas-RP, como algumas rizobactérias, podendo-se dizer, definitivamente, que o acúmulo de proteínas-RP não é um prérequisito para a indução de resistência. Entretanto, dada a ação antipatogênica de algumas dessas proteínas, elas provavelmente contribuam para o estado de proteção contra patógenos (Van Loon, 1997).

\subsubsection{Resistência induzida por microrganismos}

Microrganismos patogênicos podem induzir resistência nas plantas contra si próprios. O desenvolvimento de resistência em plantas seguindo uma infecção já é conhecido há muito tempo. Para que a proteção tenha sucesso, as plantas devem se recuperar a partir da infecção inicial ou devem ser infectadas em um sítio/tecido que normalmente não desenvolve a doença.

O tratamento de plantas de fumo pela injeção de uma suspensão de esporos de Peronospora tabacina no tecido caulinar externo ao xilema (o caule não é um sítio de infecção para esse patógeno) protegeu as plantas contra infecções foliares. A proteção foi obtida sob várias condições de campo e foi comparável com a obtida no tratamento com metalaxyl (fungicida-padrão para a doença). Mesmo na ausência da doença, plantas imunizadas cresceram mais vigorosamente e produziram $20 \%$ a mais que as plantascontrole. A resistência induzida por P. tabacina foi demonstrada ocorrer naturalmente na costa do golfo do México, em campos comerciais de fumo altamente infectados (Tuzun et al., 1992).

De modo similar, proteção pode ser conseguida em variedades de fumo contendo o gene $\mathrm{N}$, que confere resistência ao TMV, nas quais o vírus não se torna sistêmico, pela inoculação prévia de duas folhas da parte inferior com o próprio TMV (Ye et al., 1989). 
Estudos mais refinados, utilizando componentes de patógenos como indutores bióticos de resistência, têm sido realizados. A partir de micélio de $P$. infestans, agente causal da requeima em plantas de batata e de tomate, dois tipos de elicitores já foram isolados. Um deles é uma $\beta$-1,3- $\beta$-1,6-glucana encontrada na parede celular do patógeno e o outro, um complexo de lipoglicoproteína (LGP), mais ativo que a glucana na indução de fitoalexinas em tubérculos de batata. Lipídios são o componente-ativo do complexoLGP, com destaque para os ácidos aracdônico e eicosapentaenóico. LPG, em alta concentração $(100 \mu \mathrm{g} / \mathrm{mL})$, foi efetivo em induzir resistência de curta duração, associada ao acúmulo de fitoalexinas, ocorrendo apenas no local de aplicação e somente quando a inoculação desafio se deu $48 \mathrm{~h}$ ou mais após o tratamento elicitor. Por outro lado, concentrações de 5-10 $\mu \mathrm{g} / \mathrm{mL}$ LGP não provocaram o acúmulo de fitoalexinas em tubérculos de batata, mas induziram resistência sistêmica e de maior tempo de duração (Ozeretskovskaya, 1995).

Existem também muitos exemplos onde microrganismos não patogênicos a uma espécie vegetal desencadeiam respostas de resistência nas plantas. $\mathrm{O}$ tratamento de plantas de tomate com várias linhagens de Pseudomonas syringae pv. phaseolicola (patógeno de feijão) induziu resistência localizada contra a bacteriose provocada por Corynebacterium michiganense. Somente células vivas de Pseudomonas induziram resistência, mas não aquelas mortas por aquecimento ou tratamento com ultrasom (Sule, 1988).

Finalmente, a resistência pode ser induzida por microrganismos que não são patogênicos a espécie vegetal alguma, tais como bactérias saprofíticas e fungos formadores de micorrizas. O desenvolvimento da murcha causada por Fusarium oxysporum f. sp. lycopersici foi limitado em plantas de tomate colonizadas pelo fungo formador de micorriza Glomus mosseae, onde foram notadas mudanças envolvidas com o metabolismo de fenóis e deposição acentuada de lignina nas paredes celulares do hospedeiro induzido (Dehne \& Schönbeck, 1975).

Conforme já mencionado, as rizobactérias promotoras de crescimento vegetal são apontadas como uma interessante classe de agentes indutores de resistência, sendo capazes de proteger as plantas contra doenças foliares quando utilizadas como 
tratamento de sementes ou por infestação natural/artificial do solo. Uma das vantagens das rizobactérias em relação a outros indutores bióticos da parte aérea é a menor suscetibilidade a condições de estresse, tais como radiação ultra-violeta, lavagem por chuva, e flutuações na temperatura. A resistência sistêmica induzida (RSI) mediada por rizobactérias tem sido demonstrada contra fungos, bactérias e vírus, em Arabidopsis, feijão, cravo, pepino, rabanete, fumo e tomate, sob condições nas quais a bactéria indutora e o patógeno permanecem espacialmente separados (Van Loon et al., 1998).

A RSI por rizobactérias é um processo complexo que pode envolver diversas características bacterianas, tais como o tipo de lipopolissacarídeo da parede celular, a síntese de sideróforos, e até o tipo de flagelo da rizobactéria (De Meyer \& Hofte, 1997; Pieterse et al., 2001; Van Peer \& Schippers, 1992). Os mecanismos de defesa ativados por rizobactérias incluem a síntese de fitoalexinas (Van Peer et al., 1991), aumentos na atividade de peroxidases e lignificação (Albert \& Anderson, 1987), e o acúmulo de calose e de compostos fenólicos junto à parede celular (Benhamou et al., 1996).

\subsubsection{O ativador de plantas ASM}

Certos compostos químicos naturais ou sintéticos podem desencadear respostas nas plantas similares às da RSA resultante da infecção com um patógeno necrogênico.

O éster-S-metil do ácido benzo(1,2,3) tiadiazol-7-carbotióico (acibenzolar-Smetil, ASM) é um benzotiadiazole análogo ao ácido salićlico. Da mesma forma que o ácido salicílico (AS), o ASM é um đivador químico de resistência, fornecendo proteção contra o mesmo espectro de patógenos e ativando a expressão dos mesmos genes, quando comparado com a indução biológica da RSA (Friedrich et al., 1996). No entanto, o ASM não apresenta a grande desvantagem do AS, que é a de ser fitotóxico às culturas em uma dose muito próxima à necessária para induzir resistência. Por isso, o ASM se constituiu no primeiro ativador vegetal ("plant activator") sintético de RSA disponível, tendo sido liberado para comercialização na Europa com o nome comercial de BION e nos Estados Unidos como ACTIGARD. No Brasil, com o nome de BION, o produto está registrado para as culturas do cacau, tomate e citros. 
Dentre outras culturas, existem relatos do ASM induzindo resistência em trigo contra patógenos fúngicos, em feijão contra fungos e bactérias, em fumo e em Arabidopsis contra fungos, bactérias e vírus.

ASM tem mostrado induzir resistência contra algumas doenças onde medidas eficazes de controle são raras ou mesmo ausentes. Em tomate, por exemplo, o tratamento com o ASM protegeu as plantas contra a podridão radicular causada por Fusarium oxysporum f. sp. radicis-lycopersici (Benhamou \& Belanger, 1998).

Uma única aplicação de ASM a $0,1 \mathrm{mM}$ junto às raízes de plantas de tomate jovens, 7 dias antes da transmissão de vírus através do pulgão Aphis gossypii, induziu resistência nas folhas superiores contra uma das mais agressivas linhagens do Cucumber mosaic virus (CMV), sabida de causar severa necrose e perda de produção em diferentes países. A redução na incidência da virose nas plantas previamente tratadas com o ASM foi de aproximadamente 9 vezes e a explicação mais provável para o resultado é a de que o produto foi translocado até as folhas superiores, ativando genes RSA envolvidos na redução da replicação viral (Anfoka, 2000).

Romero et al. (2001) mostraram que o ASM foi efetivo no controle da mancha bacteriana do pimentão em campo, induzindo RSA em cultivares com nenhum gene de resistência, bem como naqueles com genes maiores de resistência. A resistência induzida foi expressa tão cedo quanto 3 dias após o tratamento com ASM e durou pelo menos duas semanas. Em geral, as produções das plantas tratadas com o ASM foram significativamente maiores do que as das plantas não tratadas, mas menores que as do tratamento-padrão, que envolve o uso de cobre e maneb. Houve efeito negativo na produção, em consequiência da redução do número de gemas florais e do atraso na maturação de frutos, quando o ASM foi aplicado intensivamente (uma vez por semana, num total de oito aplicações durante o ciclo da cultura).

Portanto, deve-se ter cautela na recomendação do tratamento com um ativador de defesa vegetal. Os dados de Romero et al. (2001) no patossistema pimentão x Xanthomonas vesicatoria suportam a hipótese de que pode haver um custo quando a resistência induzida é expressa constitutivamente. Em outras interações planta-patógeno onde os mecanismos de defesa foram induzidos, houve balanço favorável à produção 
quando os fitopatógenos estavam presentes, mas perda de produção na ausência dos patógenos, sugerindo que a resistência induzida tem um custo inerente (Balwin, 1998). E o problema na alocação de recursos da planta pode ser agravado se os indutores forem utilizados sob condições de estresse para as culturas.

\subsection{Patossistemas estudados}

\subsubsection{A antracnose do pepineiro causada por Colletotrichum lagenarium}

A antracnose é uma doença muito importante não só pela frequiência com que incide como também pelos danos que causa às culturas de pepino e de outras cucurbitáceas. As plantas podem ser afetadas em qualquer estádio de desenvolvimento e todos os órgãos aéreos são suscetíveis.

Colletotrichum lagenarium (Pass.) Ellis \& Halsted provoca lesões foliares encharcadas, circulares, de cor parda e centro claro, as quais podem coalescer, resultando em extensas áreas necrosadas. Nas hastes, pecíolos e em frutos, as lesões são elípticas e deprimidas, podendo apresentarem-se recobertas de massa rosada, constituída de esporos do fungo (Kurozawa \& Pavan, 1997).

$\mathrm{O}$ fungo sobrevive em sementes e em restos culturais por vários anos. As sementes contaminadas são as responsáveis pela disseminação do patógeno a longas distâncias, enquanto que a disseminação dentro da área de plantio é realizada principalmente por gotas da água de irrigação ou da chuva, as quais carregam os conídios produzidos em acérvulos para as plantas vizinhas (Blancard et al., 1996). $C$. lagenarium apresenta uma grande variabilidade patogênica, representada pelo extensivo número de raças fisiológicas já detectado, dificultando a obtenção de novas variedades e/ou híbridos resistentes (Kurozawa \& Pavan, 1997).

A doença é muito favorecida por ambiente de alta umidade relativa e temperaturas entre 19 e $24{ }^{\circ} \mathrm{C}$. Nessas condições, o período de incubação é inferior a 7 dias (Blancard et al., 1996).

Entre as medidas recomendadas para o controle da antracnose, destacam-se: a utilização de sementes sadias, o emprego de materiais resistentes, a rotação de culturas, 
o manejo adequado da irrigação e a utilização de fungicidas. Em ambiente protegido, é importante ainda a ventilação diária no interior das estufas, de modo a evitar a condensação noturna do vapor de água, que favorece a esporulação e infecção pelo fitopatógeno.

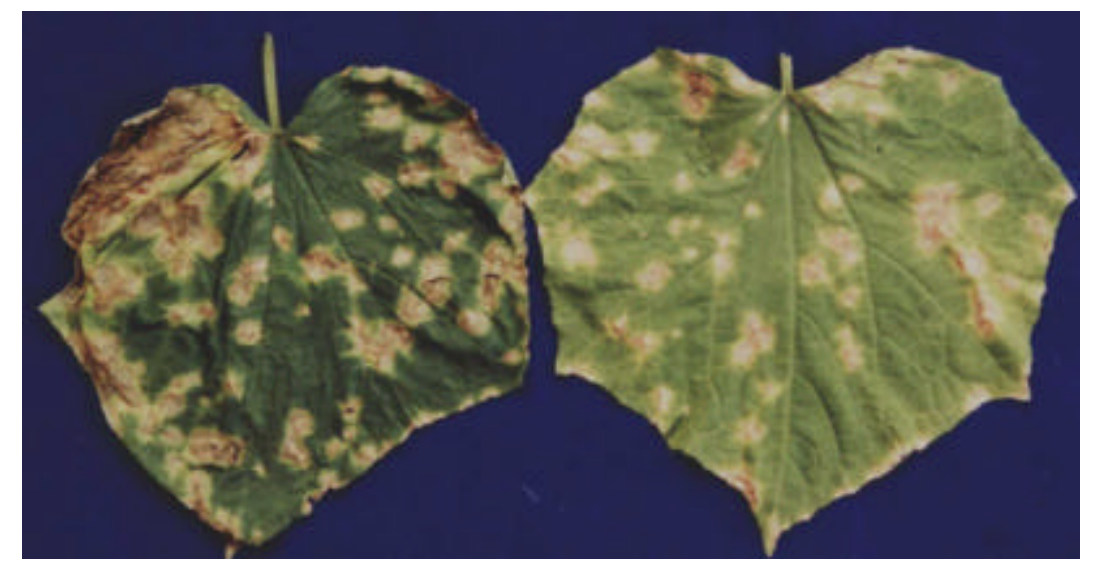

Figura 4 - Folhas de pepino com sintomas da antracnose provocada por Colletotrichum lagenarium, 10 dias após a inoculação. Escala $1: 2,4$

\subsubsection{O endurecimento dos frutos do maracujazeiro provocado pelo PWV}

Nativo da América tropical, o maracujazeiro encontra no Brasil condições ideais para o seu cultivo. Existem cerca de 580 espécies de maracujazeiro, com destaque para Passiflora edulis f. flavicarpa (maracujá amarelo) e P. alata (maracujá doce). Possuindo uma área plantada de aproximadamente 40.000 ha, o Brasil se destaca como o principal produtor mundial de maracujá. Em 1995, as principais regiões produtoras eram o Nordeste e o Norte e os principais estados produtores eram Pará e Bahia. No entanto, esse panorama mudou recentemente em virtude de problemas fitossanitários.

A produção da região Norte caiu aproximadamente $80 \%$ nos últimos anos, enquanto a da região Sudeste cresceu de forma acentuada, passando de 57 mil toneladas em 1988 para 125 mil toneladas em 1996 e para 116 mil toneladas em 1999 (FNP, 2002). O crescimento da área colhida foi ainda mais acentuado, passando de 3,6 mil ha em 1988 para 10,2 mil ha em 1996 em todo o Sudeste, o que representa um aumento da ordem de $179 \%$. A produtividade média do maracujá azedo na região Sudeste, na década 
de 90, oscilou entre 11 e 15 t/ha. Fatores como qualidade das mudas, clima, fertilidade do solo, tratos culturais e doenças afetam decisivamente esse parâmetro (Piza Júnior, 1998).

Um dos problemas limitantes à cultura em muitos locais é a doença provocada pelo Passion fruit woodiness virus (PWV - vírus do endurecimento dos frutos). Descrito primeiramente por McKnigth (1953), o PWV pertence ao gênero Potyvirus e apresenta partículas flexuosas de 750 × $12 \mathrm{~nm}$. O genoma do PWV consiste de RNA de fita simples, com polaridade positiva (Hollings \& Brunt, 1981). O vírus tem uma capa proteica com 30-36 kDa e produz, no citoplasma das células infectadas, uma proteína de inclusão cilíndrica de $66 \mathrm{kDa}$ e uma proteína de inclusão amorfa de $51 \mathrm{kDa}$ (Jan \& Yeh, 1995). O PWV encontrado no Brasil apresenta características semelhantes às do descrito na Austrália, local de primeiro relato do vírus (McKnight, 1953).

O vírus infecta plantas de 44 espécies em 21 gêneros de seis famílias. No Brasil, há relatos da ocorrência de PWV em espécies cultivadas ou silvestres de Passiflora e em Phaseolus vulgaris (Inoue et al., 1995). PWV já foi demonstrado infectar sistemicamente outras culturas, como amendoim, centrosema, crotalaria, soja, fumo (Taylor \& Greber, 1973; Chang, 1992). Em Chenopodium quinoa, o PWV causa apenas lesões locais nas folhas inoculadas (Rezende, 1994).

A transmissão do PWV é realizada por afídeos de maneira não-persistente (através da picada de prova), destacando-se as espécies-vetoras Myzus persicae e Aphis gossypii. O vírus não passa pelas sementes de maracujá ou de feijoeiro (Chang, 1992; Inoue et al., 1995).

A doença provocada pelo PWV em plantas de maracujá trata-se de uma virose encontrada em várias regiões do mundo e do Brasil, sendo considerada uma das mais importantes da cultura. Caracteriza-se por apresentar sintomas de mosaico foliar, com intensidade variada, induzindo embolhamento e deformações nas folhas (nos casos mais severos). Frutos de plantas afetadas são deformados e podem apresentar a casca bastante endurecida e sem valor comercial (Taylor \& Greber, 1973). Plantas infectadas apresentam nanismo acentuado. $O$ endurecimento dos frutos não é específico da infecção com o PWV, o que torna esse sintoma de valor reduzido para o diagnóstico. Ao 
nível microscópico, células do parênquima foliar de plantas infectadas apresentam cloroplastos com diferentes graus de desorganização. Em secções ultra-finas, inclusões lamelares e do tipo cata-vento podem ser abundantemente vistas no citoplasma de tecidos doentes (Inoue et al., 1995).

A longevidade e a produtividade das plantas atacadas é reduzida, além do que, os frutos produzidos em plantas infectadas pelo PWV podem ficar pequenos, deformados e endurecidos, tornando-se inviáveis para o comércio. A abundância de hospedeiros alternativos do vírus e a alta população de vetores na área de cultivo são condições favoráveis à ocorrência de epidemias, as quais se tornam tanto mais importantes economicamente quanto mais jovens forem as plantas no início da infecção (Rezende, 1994).

A quantificação de danos provocados pelo PWV no estado de São Paulo foi avaliada por Gioria et al. (2000). Na região da Alta Paulista, PWV é o vírus predominante, infectando $71,8 \%$ das 991 plantas inspecionadas, presentes em 45 pomares investigados. Experimentos conduzidos pelos mesmos autores em casa de vegetação revelaram diminuição da ordem de 30 a $45 \%$ no índice de área foliar, enquanto que, em telado, plantas de maracujá infectadas aos 2 meses tiveram perdas de produção superiores a $80 \%$ em relação a plantas infectadas tardiamente (após 7 meses do plantio).

Entre as medidas recomendadas para o controle, destacam-se aquelas de caráter preventivo: a eliminação de pomares abandonados, a implantação do pomar com mudas sabidamente sadias (indexação), o controle de daninhas e outros hospedeiros intermediários, a realização de inspeções periódicas para eliminar as plantas doentes (Pio-Ribeiro \& Mariano, 1997).

Uma vez detectada a doença em local que apresente vetores em abundância, poucas alternativas restam ao produtor e, muitas vezes, o prejuízo é total. Materiais de interesse agronômico resistentes ou tolerantes ao PWV ainda não são disponíveis no Brasil, e o controle químico do vetor é ineficiente, dadas as relações vírus-vetor encontradas nesse patossistema. 
A premunização de mudas de material tolerante à doença (híbridos entre maracujá-roxo e amarelo) com estirpes fracas é uma medida adotada com êxito na Austrália (Taylor \& Greber, 1973). No Brasil, as estirpes fracas de PWV selecionadas não asseguraram proteção duradoura contra a estirpe forte (Novaes, 2002).

Outra linha de pesquisa envolve a obtenção de plantas resistentes geneticamente engenheiradas. Proteção mediada pela capa proteica viral é uma estratégia de sucesso contra Potyvirus, incluindo o Potato virus Y (Farinelli \& Malnoe, 1993), o Papaya ringspot virus (Ling et al., 1991), e o Lettuce mosaic virus (Dinant et al., 1993). Yeh \& Chu (1996) transformaram plantas de fumo com o gene da capa proteica do PWV e mostraram que o vírus foi incapaz de se replicar em quatro das sete linhagens transgênicas obtidas, quando estas foram desafiadas mecanicamente com diferentes concentrações do vírus. Essa resistência completa ao PWV em fumo transgênico poderia ser utilizada como modelo na tentativa de se obter o controle da virose no maracujazeiro (Yeh \& Chu,1996).
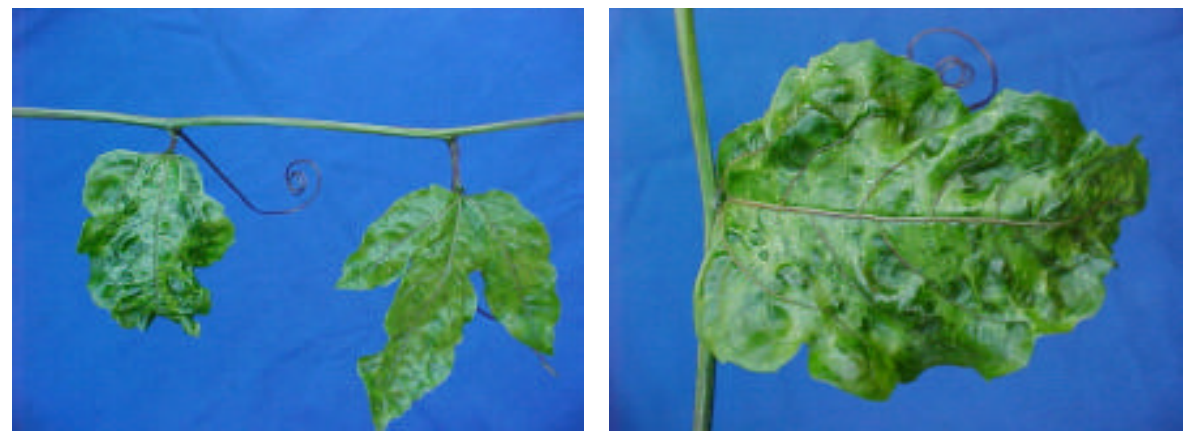

Figura 5 - Planta de maracujá com folhas exibindo sintomas da virose provocada por Passion fruit woodiness vírus, 30 dias após a inoculação

\subsubsection{A mancha bacteriana do tomateiro provocada por Xanthomonas campestris pv. vesicatoria}

A mancha bacteriana do tomateiro (Lycopersicon esculentum Mill) é causada por Xanthomonas campestris pv. vesicatoria, que também ataca outras solanáceas como pimentão (Capsicum annuum L.), podendo provocar significativas perdas, principalmente em ambientes quentes e úmidos. A doença encontra-se espalhada pelo 
mundo (Goode \& Sasser, 1980). No Brasil, é uma das doenças mais importantes do tomateiro, em especial nas regiões Centro-Oeste, Norte e Nordeste, onde ocorrem temperaturas elevadas aliadas à alta umidade relativa proporcionada por chuvas ou irrigação por aspersão (Mello et al., 1996).

A bactéria pode atacar todos os tecidos da parte aérea da planta, reduzindo a produtividade pela destruição de tecido foliar, e pela derrubada de flores e frutos em formação, além de comprometer a qualidade dos frutos para o comércio. A bactéria penetra na planta através dos estômatos e de ferimentos provocados por equipamentos ou pela abrasão de partículas de solo movimentadas pelo vento. A disseminação ocorre por respingos de água, a curtas distâncias, ou por material de plantio infectado, a longas distâncias (Lopes \& Santos, 1994).

A sobrevivência da bactéria ocorre em sementes infectadas, em restos culturais no solo e epifiticamente em plantas daninhas da família solanáceae, as quais podem servir de fonte de inóculo bacteriano. Além de introduzir a doença em uma área isenta da mesma, a presença de $X$. campestris vesicatoria nas sementes provoca inibição na germinação, tanto maior quanto mais elevado for o inóculo presente (Bashan, 1986).

As estratégias utilizadas no manejo integrado da doença envolvem o uso de sementes e mudas livres do patógeno, medidas de sanitização, práticas culturais como a rotação de culturas e o manejo adequado da irrigação, controle químico, utilização de materiais resistentes, entre outras.

Pulverizações de bactericidas cúpricos, em conjunto com maneb, zineb e mancozeb ou estreptomicina são freqüentemente usados para o controle da mancha bacteriana. Os níveis de controle desses produtos químicos variam e, por terem sido utilizados repetidas vezes na mesma área, linhagens da bactéria resistentes a cobre, zinco e estreptomicina já foram selecionadas no passado (Adaskaveg \& Hine, 1985).

Sem dúvida, a utilização de materiais resistentes ao patógeno é uma importante medida dentro do manejo da doença. Fontes genéticas de resistência existem tanto em tomate quanto em pimentão. Entretanto, a ampla diversidade genética da bactéria tem dificultado o desenvolvimento de uma resistência durável (Bouzar et al., 1999). A variação patogênica nas populações da bactéria é geralmente expressa em termos da 
existência de raças fisiológicas, que são distintas com base na virulência sobre genótipos específicos de tomate e pimentão (O'Garro, 1998).

Homologia de DNA entre as Inhagens de $X$. campestris pv. vesicatoria foi usada como base para propor a existência de dois grupos geneticamente distintos, os grupos A e B. Análises fenotípicas e bioquímicas mostraram que as linhagens do grupo A são caracterizadas pela incapacidade de hidrolizar amido e pectato, pela expressão de uma proteína com $32 \mathrm{kDa}$, pela reação com anticorpos monoclonais 1 e 21 e ainda por apresentar quantidade relativa de ácidos graxos maior que a encontrada nas linhagens do grupo B. Essas, por sua vez, caracterizam-se por serem amilolíticas e pectolíticas, expressarem uma proteína de $27 \mathrm{kDa}$ e reagirem com os anticopros monoclonais 8 e 15 . As linhagens dos grupos A e B também diferem em termos de patogenicidade. Linhagens que infectam tomate podem pertencer aos grupos $\mathrm{A}$ ou $\mathrm{B}$, enquanto que todas as linhagens que infectam pimentão pertencem ao grupo A (Bouzar et al., 1994).

Os grupos A e B compartilham menos de 50\% de homologia no DNA, indicando que eles provavelmente representam duas espécies distintas. Dessa forma, Vauterin et al. (1995), reclassificando o gênero Xanthomonas, subdividiram a espécie X. campestris pv. vesicatoria em duas espécies distintas. As linhagens do grupo $\mathrm{B}$, que infectam apenas tomateiro, estão atualmente classificadas como a espécie Xanthomonas vesicatoria, enquanto as do grupo $\mathrm{A}$, que podem infectar tanto plantas de tomate quanto de pimentão, estão classificadas como $X$. axonopodis pv. vesicatoria.
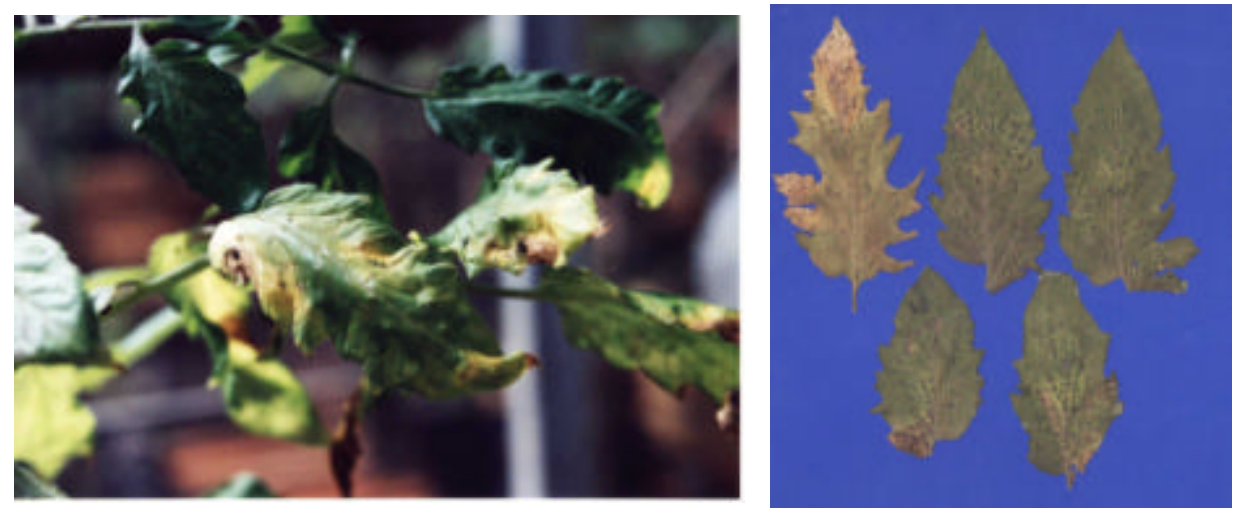

Figura 6 - Folíolos de tomateiro mostrando sintomas da bacteriose provocada por Xanthomonas vesicatoria, 25 dias após a inoculação. Escala $1: 3$ 


\section{INDUÇÃo de RESISTÊNCIA EM PLANTAS DE PEPINO CONTRA}

Colletotrichum lagenarium PELA APLICAÇÃO DE EXTRATOS DE BASIDIOCARPOS DE Lentinula edodes (cogumelo shiitake) E DE Agaricus blazei (cogumelo-do-sol)

\section{Resumo}

A aplicação de microrganismos (células ou metabólitos) e de agentes abióticos (soluções salinas, hormônios vegetais, produtos sintéticos), entre outros, pode desencadear a ativação de mecanismos de defesa nas plantas. O fenômeno da indução de resistência já foi demonstrado em diferentes patossistemas, sendo a interação pepineiro $\mathrm{x}$ Colletotrichum lagenarium muito utilizada para a descoberta e o estudo do modo de ação de novos indutores. Os cogumelos Lentinula edodes (shiitake) e Agaricus blazei (cogumelo-do-sol) sintetizam antibióticos, substâncias ativadoras do sistema imunológico e outros compostos de interesse medicinal, alguns dos quais poderiam proteger espécies vegetais contra patógenos de importância agronômica. Com o objetivo de avaliar o potencial desses cogumelos para a indução de resistência, plantas de pepino foram tratadas com extratos aquosos do basidiocarpo de diferentes isolados dos cogumelos e, após um intervalo de tempo, inoculadas com o agente causal da antracnose. Os testes foram conduzidos sob condições de casa de vegetação, em delineamento inteiramente casualizado, e os tratamentos realizados quando as plantas se encontravam no estádio de três folhas verdadeiras. A redução parcial na severidade da doença foi obtida nas folhas pré-tratadas com os extratos (proteção local), bem como sistemicamente. O efeito protetor foi dependente da concentração do extrato de cogumelo utilizada e, em menor grau, do intervalo de tempo entre indução-inoculação e do ambiente. De modo geral, os isolados de L. edodes foram um pouco mais eficientes 
que os de A. blazei. Estudando o modo de ação dos cogumelos, os extratos aquosos de basidiocarpo dos diferentes isolados não inibiram o crescimento micelial e a germinação de esporos in vitro de $C$. lagenarium. Por outro lado, o extrato de shiitake (mistura dos isolados LE 96/17 e LE 96/22) provocou um aumento nas atividades de quitinases e principalmente de peroxidases nas plantas tratadas, enzimas que, muitas vezes, apresentam participação na resistência vegetal contra fungos fitopatogênicos. Com base nos resultados, conclui-se que os cogumelos L. edodes e A. blazei apresentam potencial para induzir resistência em plantas de pepino contra C. lagenarium.

\section{Summary}

The application of microorganisms or abiotic agents can activate defense mechanisms in plants against pathogens. The induced resistance phenomenon was demonstrated to occur in different host-parasite interactions. The interaction between cucumber and Colletotrichum lagenarium is commonly used to discover new inducers and their mode of action. The mushrooms Lentinula edodes and Agaricus blazei synthesize, among other biologically active compounds, antibiotics, substances that activate the immune system in animals and others of medicinal interest. Thus, some of these compounds might protect plants against important diseases. With the aim of evaluating the potential of these mushrooms to induce resistance in plants, cucumber leaves were treated with fruiting body aqueous extracts from different isolates of $L$. edodes and A. blazei and latter inoculated with the anthracnose causal agent. The experiments were carried out under greenhouse conditions, in a random entirely design, and the treatments were done when the plants exhibited three true leaves. The partial reduction on disease severity was obtained local as well as systemically. The protecting effect was dependent upon the mushroom extract concentration used and, in a lower degree, the time interval between induction-inoculation and the environment. In general, the isolates of $L$. edodes were more efficient than the A. blazei ones. The aqueous extracts from fruiting body of the different isolates did not inhibit in vitro mycelial growth and spore germination of $C$. lagenarium. On the other hand, the shitake mushroom (a mixture of the isolates LE 96/17 and LE 96/22) increased peroxidase and 
quitinase activities in the treated plants. Based upon the results, the L. edodes and A. blazei mushrooms exhibit a potential to induce resistance in cucumber plants against $C$. lagenarium.

\subsection{Introdução}

A antracnose do pepino (Cucumis sativus L.), provocada por Colletotrichum lagenarium (Pass.) Ellis \& Halsted, é uma doença importante dentro da cultura, principalmente em ambientes úmidos. Nessas condições, práticas agrícolas preventivas e materiais resistentes podem não ser suficientes para evitar epidemias severas, e a utilização de fungicidas protetores ou curativos deverá se fazer necessária, onerando o custo de produção (Thompson \& Jenkins, 1985).

Além da importância econômica para os produtores de cucurbitáceas, a interação pepino x $C$. lagenarium destaca-se no meio científico em função de ser um patossistema clássico para o estudo da resistência induzida, com o qual muitas das características do fenômeno foram descobertas ou confirmadas.

O trabalho de Kuc et al. (1975) pode ser considerado um marco no estudo da indução de resistência em plantas. Os autores demonstraram que a inoculação prévia de uma folha de pepino com $C$. lagenarium resultou, dentro de uma semana, na proteção sistêmica da planta inteira contra subseqüiente desafio pelo mesmo fitopatogéno. Essa resistência foi caracterizada por um decréscimo no tamanho e número de lesões desenvolvidos (Kuc \& Richmond, 1977). A proteção sistêmica desencadeada pela inoculação da primeira folha com $C$. lagenarium não foi superada por uma alta pressão de inóculo $\left(10^{7}\right.$ esporos $\left./ \mathrm{mL}\right)$ aplicada tempos depois na segunda folha (Dean \& Kuc, 1986). Uma única infecção indutora protegeu plantas de pepino por várias semanas, enquanto uma inoculação booster, duas a três semanas após a primeira infecção, conduziu a uma ampla resistência de longa duração (Guedes et al., 1980).

Utilizando $C$. lagenarium como indutor, evidencia-se que a resistência sistêmica adquirida opera contra vários patógenos. Staub \& Kuc (1980) relataram que a infecção de uma folha de pepino por $C$. lagenarium protegeu sistemicamente contra Cladosporium cucumerinum, agente causal da sarna. Nesse estudo, foram utilizados 
cultivares resistentes e suscetíveis à antracnose, sugerindo que o desenvolvimento de uma lesão necrótica não é um pré-requisito para a indução de resistência. Inoculação prévia com o patógeno $C$. lagenarium, nas primeiras duas folhas de pepino induziu resistência à virose provocada pelo Cucumber mosaic virus (CMV), evidenciada como um atraso no aparecimento de sintomas de mosaico pela planta (Bergstrom et al., 1982). Até mesmo a infecção de cotilédones de pepino com $C$. lagenarium induziu resistência contra os patógenos radiculares Rhizoctonia solani e Fusarium oxysporum f. sp. cucumerina (Gessler \& Kuc, 1982; Kubota \& Abiko, 2001), demonstrando, dessa forma, que o sinal para a ativação dos mecanismos de defesa pode se mover para abaixo da folha induzida e que o sistema radicular também responde à indução.

Se por um lado, C. lagenarium induz resistência a muitos patógenos, por outro, existem também vários indutores bióticos e mesmo abióticos de resistência contra a antracnose. Plantas de pepino cujas sementes foram tratadas com rizobactérias promotoras de crescimento mostraram significativa redução na mancha foliar causada por Pseudomonas syringae pv. lacrymans e na antracnose causada por C. lagenarium, além de maior número de folhas e peso de frutos por planta, em três experimentos de campo conduzidos durante 2 anos (Wei et al., 1996).

Ácido oxálico, isolado a partir de folhas de espinafre ou ruibarbo, também induziu resistência à antracnose, assim como fosfatos de potássio di ou tri-básico. As soluções de sais de potássio que induziram resistência sistêmica contra a doença provocaram pontuações cloróticas nas folhas tratadas, que evoluíram junto à necrose restrita. Por outro lado, os compostos que provocaram danos severos, com rápida morte celular, não protegeram as plantas de pepino (Gottstein \& Kuc, 1989). A partir desses resultados, esses autores sugeriram que a resistência sistêmica desencadeada por infecções não ocorre em função de um componente específico de um patógeno, mas pela persistência de um baixo nível de perturbação metabólica na planta.

Estudando o mecanismo de ação de indutores sobre plantas de pepino, Dean \& Kuc (1987) mostraram que a resposta de lignificação é significativamente mais rápida em plantas exibindo resistência sistêmica, o que pode ser correlacionado com um aumento na atividade de peroxidases. Plantas de pepino contêm três peroxidases acídicas 
que aumentaram sistemicamente após infecção e foram prontamente extraídas a partir dos espaços intercelulares. De forma semelhante, resistência sistêmica a Sphaerotheca fuliginea, agente causal do oídio, foi relacionada com redução na penetração pelo patógeno, devido à lignificação dos tecidos induzidos (Conti et al., 1990).

Kováts et al. (1991) encontraram papilas contendo glucana (calose) sob apressórios de $C$. lagenarium em pepino com resistência induzida, enquanto Stein et al. (1993), utilizando micro-análises de raio-X, relataram a presença de silício sob apressórios cujas hifas não penetraram. Dessa maneira, parece que plantas de pepino usam pelo menos três barreiras para fortalecer a parede celular contra uma infecção fúngica: lignina, calose e silício.

Além das peroxidases, envolvidas na lignificação, outras enzimas têm sido ativadas durante a indução da resistência. Métraux \& Boller (1986) mostraram que a inoculação de uma folha de pepino com $C$. lagenarium, $P$. syringae pv. lacrhymans ou Tobacco necrosis virus (TNV) resultou em expressão local e sistêmica da atividade de quitinases. Injeção de ácido salicílico, um indutor abiótico, junto às folhas ou pecíolos de pepino também desencadeou a expressão gênica dessas enzimas.

Em nosso caso, a atenção está voltada para se avaliar a capacidade dos cogumelos L. edodes e A. blazei em induzir resistência em plantas, tentando também elucidar o modo de ação dos mesmos. Esses cogumelos têm sido utilizados na área médica, prevenindo doenças em animais pela ação direta contra patógenos e, indiretamente, por ativar o sistema imunológico. O cogumelo shiitake já demonstrou potencial para proteger plantas contra doenças fúngicas e bacterianas (Piccinin, 2000; Pacumbaba et al., 1999), porém, os mecanismos de ação envolvidos na proteção não foram investigados. Dessa forma, adotou-se o patossistema pepino x C. lagenarium para a concretização dos objetivos propostos. 


\subsection{Material e Métodos}

\subsubsection{Obtenção dos preparados de L.edodes e de A. blazei}

Para a obtenção do extrato aquoso de cada isolado, o pó seco de basidiocarpo recebeu água destilada (14 $\mathrm{mL}$ para cada grama), e após $24 \mathrm{~h}$ de incubação a $4{ }^{\circ} \mathrm{C}$, a suspensão foi filtrada em filtro comum (gramatura: $8 \mathrm{~g} / \mathrm{cm}^{2}$ ) e centrifugada a 20.000 g/25 min, sendo o sobrenadante filtrado em membrana tipo Millipore (diâmetro do poro $=0,2 \mu \mathrm{m}$ ), sob condições assépticas. Os filtrados esterilizados (extratos aquosos concentrados) foram armazenados em geladeira a $4{ }^{\circ} \mathrm{C}$ e tilizados, após diluições, na maioria dos testes de proteção de plantas. O extrato aquoso a $10 \%$ v/v $(10 \mathrm{~mL}$ de extrato concentrado $+90 \mathrm{~mL}$ de água destilada) contém o equivalente a 7,15 mg pó seco de basidiocarpo em cada $\mathrm{mL}$. Quando não especificado nas tabelas e figuras, os isolados de L. edodes utilizados representam uma mistura de basidiocarpos produzidos em Eucaliptus grandis e em E. saligna. Os basidiocarpos dos isolados de A. blazei são provenientes de cultivo axênico.

\subsubsection{Planta e patógeno}

Utilizou-se a cultivar de pepino denominada Caipira Verde, cujas sementes foram adquiridas em estabelecimentos agropecuários em Piracicaba, SP.

O fitopatógeno, Colletotrichum lagenarium, foi mantido em folhas de pepino infectadas e herbarizadas, durante todo o período de realização dos experimentos. Para o isolamento fúngico, procedeu-se a desinfestação de pedaços foliares, obtidos a partir da região de transição entre tecido sadio e tecido doente, com hipoclorito de sódio comercial (1\%) e disposição dos mesmos em meio de cultivo ágar-água (AA) 2\%. Após a obtenção de culturas puras, o fungo foi repicado para meio de batata-dextrose-ágar (BDA), a $25{ }^{\circ} \mathrm{C}$, sob luz fluorescente constante, visando estimular o crescimento micelial. Para induzir o fungo à esporulação, pedaços de meio AA contendo micélio do fitopatógeno foram repicados para o meio de cultivo aveia-ágar, com incubação das placas a $23{ }^{\circ} \mathrm{C}$, sob luz negra (faixa de comprimento de onda em torno de $320 \mathrm{~nm}$ ). 


\subsubsection{Proteção de plantas de pepino em casa de vegetação utilizando extratos dos basidiocarpos de A. blazei e de L. edodes}

Os extratos aquosos dos basidiocarpos, em diferentes concentrações, foram aplicados, separadamente, por aspersão em plantas de pepino apresentando duas folhas verdadeiras. Após um determinado intervalo de tempo, a segunda e a terceira folhas foram inoculadas com $C$. lagenarium (aspersão de uma suspensão contendo de 3 a 5 x $10^{4}$ esporos $/ \mathrm{mL}$ ) e mantidas em câmara úmida durante $24 \mathrm{~h}$, para verificação de proteção local e sistêmica, respectivamente. Foram realizadas cinco repetições por tratamento, sendo cada repetição representada por um vaso contendo duas plantas. A avaliação da severidade da doença foi realizada de 7 a 10 dias após a inoculação das plantas.

Em outro experimento com pepino, nos moldes do descrito anteriormente, testouse o efeito dos extratos dos cogumelos no desenvolvimento das plantas. Foram avaliados a altura e também a área foliar total, utilizando-se do medidor de área foliar LI-3000, LICOR $^{\circledR}$.

\subsubsection{Efeito in vitro dos extratos de basidiocarpos dos cogumelos sobre o crescimento micelial e a germinação de esporos de $C$. lagenarium}

Para testar o efeito dos cogumelos sobre o crescimento micelial de $C$. lagenarium, os extratos aquosos de basidiocarpos dos diferentes isolados foram incorporados em BDA a $45{ }^{\circ} \mathrm{C}$, nas proporções de 5 ou $10 \%$ e vertidos em placas de Petri. Após solidificação do meio de cultivo, cada placa recebeu um disco de $0,5 \mathrm{~cm}$ de diâmetro contendo micélio de $C$. lagenarium, na parte central. As placas, em número de cinco para cada tratamento, foram mantidas a $26 \pm 1{ }^{\circ} \mathrm{C}$, sob condições de escuro. $\mathrm{O}$ crescimento diametral $(\mathrm{em} \mathrm{cm})$ das colônias fúngicas foi registrado aos 4 e aos 8 dias após a repicagem do fitopatógeno.

A influência dos extratos sobre a germinação dos esporos e a formação de apressórios por $C$. lagenarium foi determinada através do uso de placas de ELISA. Cada pocinho de uma placa recebeu $40 \mu \mathrm{l}$ de um dos tratamentos e $40 \mu \mathrm{l}$ da suspensão de esporos do fungo, de tal forma que a concentração final dos extratos de basidiocarpos fosse 10 e $20 \%$ (v/v) e a concentração final de C. lagenarium fosse $5 \times 10^{4}$ esporos $/ \mathrm{mL}$. 
O controle consistiu de água destilada e foram realizadas cinco repetições (cinco pocinhos) para cada tratamento. A placa de ELISA foi mantida dentro de uma câmara de crescimento a $25 \pm 1^{\circ} \mathrm{C}$, com fotoperíodo (10 h de escuro seguida por $10 \mathrm{~h}$ de luz). A porcentagem de germinação de esporos e da formação de apressórios foi avaliada $20 \mathrm{~h}$ após o início do experimento, através do emprego de azul de algodão com lactofenol e observação em microscópio ótico.

\subsubsection{Determinação da atividade de proteínas relacionadas à patogênese em pepino}

As amostras vegetais consistiram de 10 discos foliares $(1,3 \mathrm{~cm}$ de diâmetro cada), obtidos da segunda e terceira folhas verdadeiras de plantas de pepino, coletados a partir de quatro tipos de tratamentos em cada experimento: I) plantas tratadas somente com água na segunda folha verdadeira; II) plantas tratadas com água na segunda folha verdadeira e posteriormente (6 dias depois) inoculadas com C. lagenarium $\left(5 \times 10^{4}\right.$ esporos $/ \mathrm{mL}$ ) nas segundas e terceiras folhas verdadeiras; III) plantas tratadas somente com extrato de basidiocarpo na segunda folha verdadeira; IV) plantas tratadas com extrato de basidiocarpo na segunda folha verdadeira e posteriormente (6 dias depois) inoculadas com $C$. lagenarium $\left(5 \times 10^{4}\right.$ conídios $/ \mathrm{mL}$ ) nas segundas e terceiras folhas verdadeiras. Os tempos de amostragem foram 0, 3, 6, 9 e 12 dias após o tratamento com água ou com os extratos. Portanto, as coletas do $3^{\circ}$ e do $6^{\circ}$ dias continham apenas os tratamentos I e III, enquanto que no $9^{\circ}$ e $12^{\circ}$ dias, os quatro tratamentos estavam presentes.

As amostras foram maceradas na presença de nitrogênio líquido, homogeneizadas em 4,0 mL de tampão acetato de sódio $100 \mathrm{mM}(\mathrm{pH}$ 5,0) (tampão de extração) e centrifugadas a $20.000 \mathrm{~g} / 30 \mathrm{~min}$, a $4{ }^{\circ} \mathrm{C}$. Os sobrenadantes foram utilizados para se avaliar as atividades de quitinases e $\beta$-1,3-glucanases, bem como o teor de proteínas totais.

A atividade de quitinases foi avaliada através da liberação de fragmentos solúveis de quitina carboximetilada marcada com remazol brilhante violeta ("CM-Chitin-RBV"), de acordo com a metodologia de Wirth \& Wolf (1990). Para tanto, $200 \mu$ l do extrato 
protéico (sobrenadante) foram misturados com $600 \mu \mathrm{l}$ do tampão de extração e $200 \mu \mathrm{l}$ do substrato "CM-Chitin-RBV" $(2,0 \mathrm{mg} / \mathrm{mL})$. Após incubação por $60 \mathrm{~min}$ a $40{ }^{\circ} \mathrm{C}$, a reação foi paralisada com a adição de $200 \mu \mathrm{l}$ de solução de $\mathrm{HCl}$ 1,0 M. As amostras foram mantidas na geladeira por $15 \mathrm{~min}$ e centrifugadas por $5 \mathrm{~min}$ a $5.000 \mathrm{~g}$. A absorbância a $550 \mathrm{~nm}$ do sobrenadante foi então determinada tendo-se na cubeta de referência: $800 \mu \mathrm{l}$ de tampão de extração + $200 \mu \mathrm{l}$ de "CM-Chitin-RBV" + $200 \mu \mathrm{l} \mathrm{HCl} \mathrm{1,0} \mathrm{M} \mathrm{(após}$ incubação e centrifugação). Os resultados foram expressos em Unidades de Absorbância a $550 \mathrm{~nm} / \mathrm{mg}$ proteína/ $\mathrm{min}(\mathrm{UA} / \mathrm{mg}$ prot/min).

A atividade de $\beta-1,3$ glucanases nas amostras foi determinada de modo semelhante, utilizando-se o substrato "Curdlan" (4 mg/mL) ao invés de "CM-ChitinRBV”. O tempo de incubação foi de 100 min e a absorbância determinada a $600 \mathrm{~nm}$, sendo os resultados expressos em Unidades de Absorbância a $600 \mathrm{~nm} / \mathrm{mg}$ proteína/ min (UA/mg prot/min).

Outros experimentos foram conduzidos para se determinar a atividade de peroxidases nas folhas de pepino. Os tratamentos e tempos de amostragem foram similares aos realizados para quitinases e glucanases. No caso das peroxidases, no entanto, foi utilizado o tampão fosfato de sódio $0,01 \mathrm{M}(\mathrm{pH}$ 6,0) para a extração protéica. A atividade de peroxidases nas amostras foi determinada espectrofotometricamente a $470 \mathrm{~nm}$ em uma mistura de reação que consistiu de $0,1 \mathrm{~mL}$ de extrato protéico e 2,9 mL de tampão de extração, este contendo guaiacol 0,25\% (v/v) e peróxido de hidrogênio $0,1 \mathrm{M}$. A reação foi permitida de proceder por $4 \mathrm{~min}$, com as medidas de densidade óptica tomadas a cada $20 \mathrm{~s}$, iniciando-se 1 min após a adição do extrato ao substrato. Os resultados foram expressos em unidades de Densidade Óptica a $470 \mathrm{~nm} / \mathrm{mg}$ proteína/ $\mathrm{min}(\mathrm{DO} / \mathrm{mg}$ prot/min).

Conforme mencionado, as atividades de enzimas relacionadas à patogênese foram expressas em relação ao conteúdo total de proteínas das amostras, o qual foi determinado empregando-se o método de Bradford (1976). Para tal, adicionaram-se 200 $\mu \mathrm{l}$ de reagente concentrado de Bradford a $800 \mu \mathrm{l}$ do extrato proteico. Após $10 \mathrm{~min}$, realizou-se a leitura de absorbância a 595 nm. A concentração de proteínas de cada 
amostra foi expressa em $\mu \mathrm{g}$ equivalentes de albumina de soro bovino (ASB), utilizandose de curva-padrão de concentrações de ASB variando de 0 a $20 \mu \mathrm{g} / \mathrm{mL}$.

\subsection{Resultados}

\subsubsection{Proteção de plantas de pepino em casa de vegetação utilizando extratos aquosos de basidiocarpos de $A$. blazei e de L.edodes}

Houve um efeito de doses do cogumelo shiitake na severidade da antracnose em pepineiro. Extratos aquosos de basidiocarpos de shiitake a 5\%, utilizados em um intervalo de 7 dias entre aplicação dos mesmos e a inoculação das plantas com $C$. lagenarium, não provocaram redução significativa na severidade da doença. No entanto, a partir da concentração de $10 \%$, os extratos reduziram significativamente a severidade da doença tanto nas folhas que haviam recebido diretamente esses extratos (efeito local) como em folhas não-tratadas de plantas tratadas (efeito sistêmico dos extratos). $\mathrm{O}$ efeito foi semelhante para os extratos obtidos a partir de isolados cultivados em Eucalyptus grandis e em E. saligna (Figura 1).

Com relação ao experimento apresentado na Figura 1, os extratos dos isolados LE 96/17, LE 96/22 e LE JAB-K foram misturados em partes iguais para serem aplicados. No teste seguinte, a aplicação foi de extratos individuais de cada isolado, bem como da mistura dos extratos. Os resultados mostraram que os extratos de basidiocarpos reduziram significativamente a severidade da antracnose, quando aplicados a 10 ou 20\%, 6 dias antes da inoculação. A proteção local e sistêmica de pepino contra $C$. lagenarium foi semelhante para todos os isolados de shiitake testados, não havendo efeito sinergístico quando da mistura dos mesmos (Figura 2). 
○
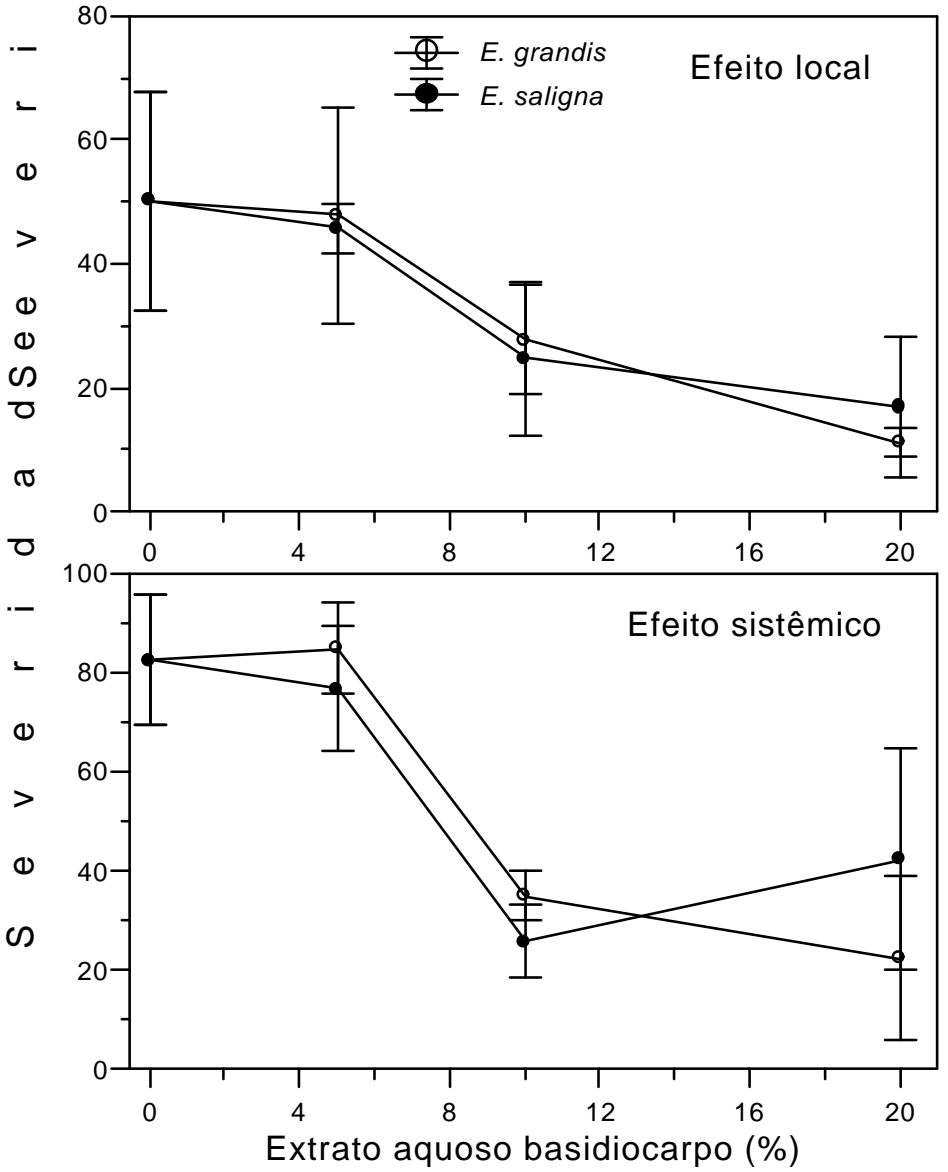

Figura 1 - Efeitos local e sistêmico dos extratos de basidiocarpos de Lentinula edodes (mistura dos isolados LE 96/17, LE 96/22 e LE JAB-K) na severidade da antracnose provocada por Colletotrichum lagenarium $\left(3 \times 10^{4}\right.$ conídios $\left./ \mathrm{mL}\right)$ em plantas de pepino. Os extratos foram aplicados 7 dias antes da inoculação das plantas. As barras representam a média \pm desvio-padrão 


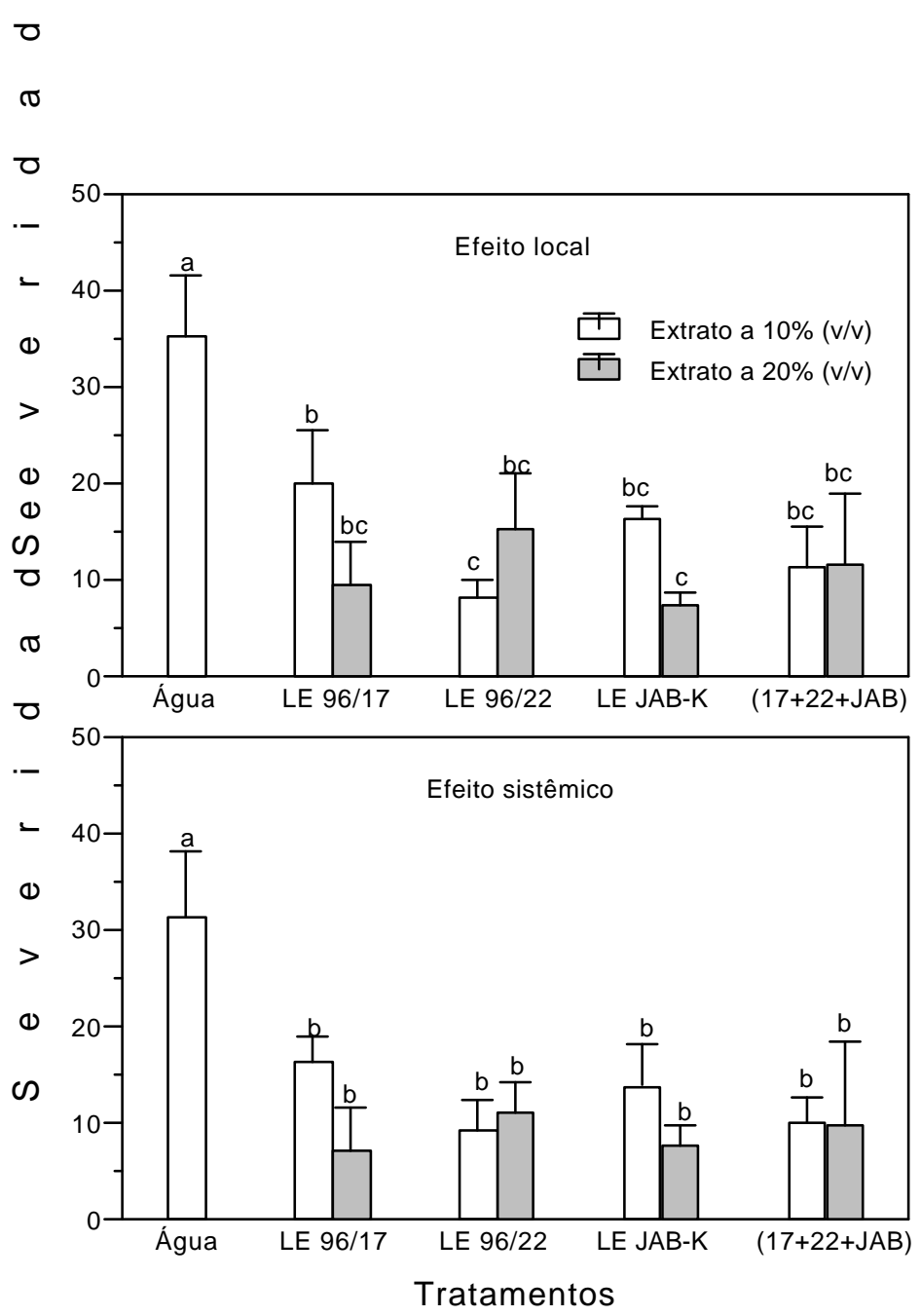

Figura 2 - Efeitos local e sistêmico dos extratos de basidiocarpos dos isolados LE 96/17, LE 96/22 e LE JAB-K de Lentinula edodes, bem como da mistura de isolados, na severidade da antracnose provocada por Colletotrichum lagenarium $\left(3 \times 10^{4}\right.$ conídios $/ \mathrm{mL}$ ) em plantas de pepino. Os extratos foram aplicados a 10 e $20 \%$ (v/v), 6 dias antes da inoculação das plantas. As barras representam a média \pm desvio-padrão. Médias seguidas pelas mesmas letras não diferem entre si pelo teste de Tukey a $5 \%$

Em outro experimento, utilizaram-se extratos do isolado ABL 97/11 de A. blazei, em diferentes concentrações, com um intervalo aplicação-inoculação de 4 dias. $\mathrm{O}$ teste $\mathrm{F}$ a 5\% de significância mostrou que houve um efeito local de concentrações dos extratos 
do isolado ABL097/11, com redução na severidade da antracnose em pepino. Já o efeito sistêmico de dosહ de ABL 97/11 não foi estatisticamente significativo (Figura 3).

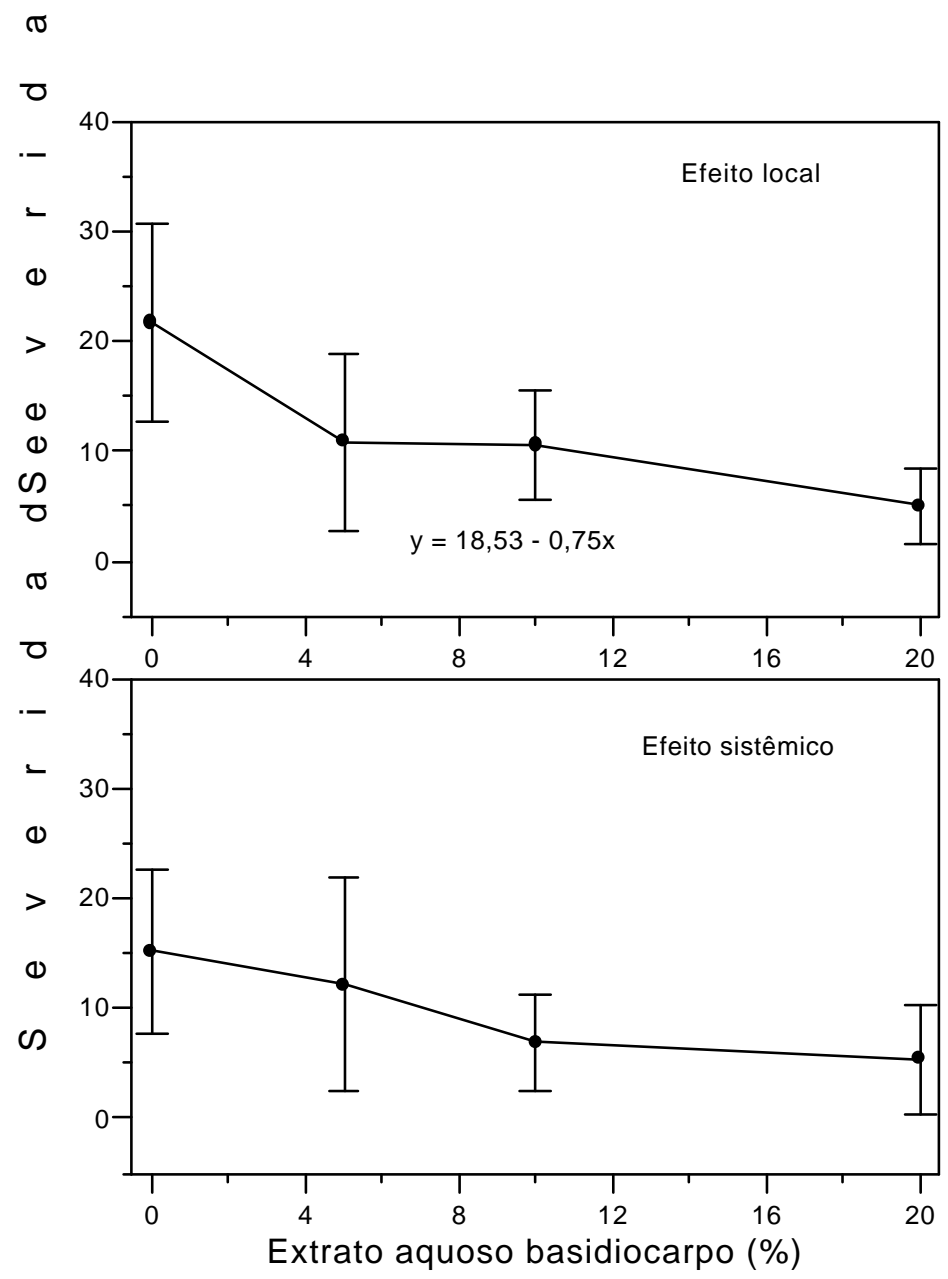

Figura 3 - Efeitos local e sistêmico dos extratos de basidiocarpos do isolado ABL 97/11 de Agaricus blazei na severidade da antracnose provocada por Colletotrichum lagenarium $\left(5 \times 10^{4}\right.$ conídios $\left./ \mathrm{mL}\right)$ em plantas de pepino. Os extratos foram aplicados 4 dias antes da inoculação das plantas. As barras representam a média \pm desvio-padrão

Comparando o efeito protetor de L. edodes e A. blazei em plantas de pepino no mesmo experimento, todos os isolados testados foram utilizados a $20 \%$ (v/v) e 
reduziram significativamente a severidade da antracnose, local e sistemicamente, não havendo diferença estatística entre os isolados. Efeito sinergístico entre LE 96/22 e ABL 97/11 não foi verificado (Figura 4). O ativador de plantas, acibenzolar-S-metil (ASM), foi quem propiciou as maiores reduções na severidade da antracnose.

O nível de proteção conferido pelo isolado LE 97/11 de L. edodes não foi dependente do intervalo de tempo entre o tratamento e a inoculação com o patógeno para os intervalos testados (2, 4 e 6 dias). Já o isolado ABL 99/29 de A. blazei, nesse mesmo teste, somente protegeu as folhas previamente tratadas quando o intervalo aplicação-inoculação foi de 2 dias (Figura 5 - efeito local). Quanto ao efeito sistêmico do isolado, o melhor resultado foi com o intervalo de 6 dias, sugerindo que haveria a necessidade de um tempo maior para a geração de um sinal sistêmico e ativação a longa distância dos mecanismos de defesa do pepino pelo isolado de A. blazei. Entretanto, no intervalo de 2 dias (mas não no de 4 dias) também houve uma pequena proteção sistêmica, o que acaba levando ao questionamento da hipótese anterior (Figura 5 - efeito sistêmico). 
ర
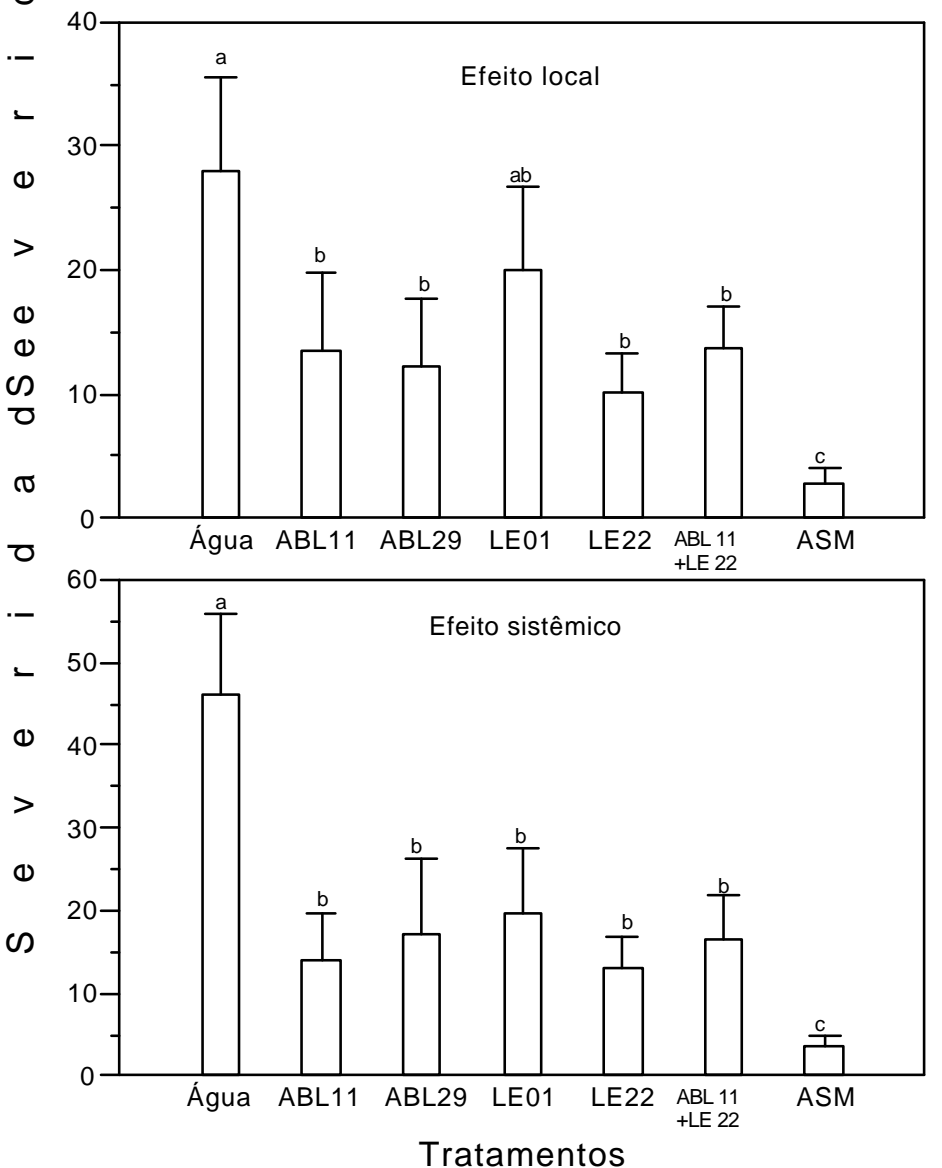

Figura 4 - Efeitos local e sistêmico dos extratos de basidiocarpos dos isolados ABL 97/11 e ABL 99/29 de Agaricus blazei e LE 95/01 e LE 96/22 de Lentinula edodes na severidade da antracnose provocada por Colletotrichum lagenarium $\left(5 \times 10^{4}\right.$ conídios $\left./ \mathrm{mL}\right)$ em plantas de pepino. Os extratos foram aplicados a $20 \%(\mathrm{v} / \mathrm{v}), 4$ dias antes da inoculação das plantas. ASM = Acibenzolar-S-metil, utilizado a $50 \mathrm{ppm}$. As barras representam a média \pm desvio-padrão. Médias seguidas pelas mesmas letras não diferem entre si pelo teste de Tukey a 5\% 


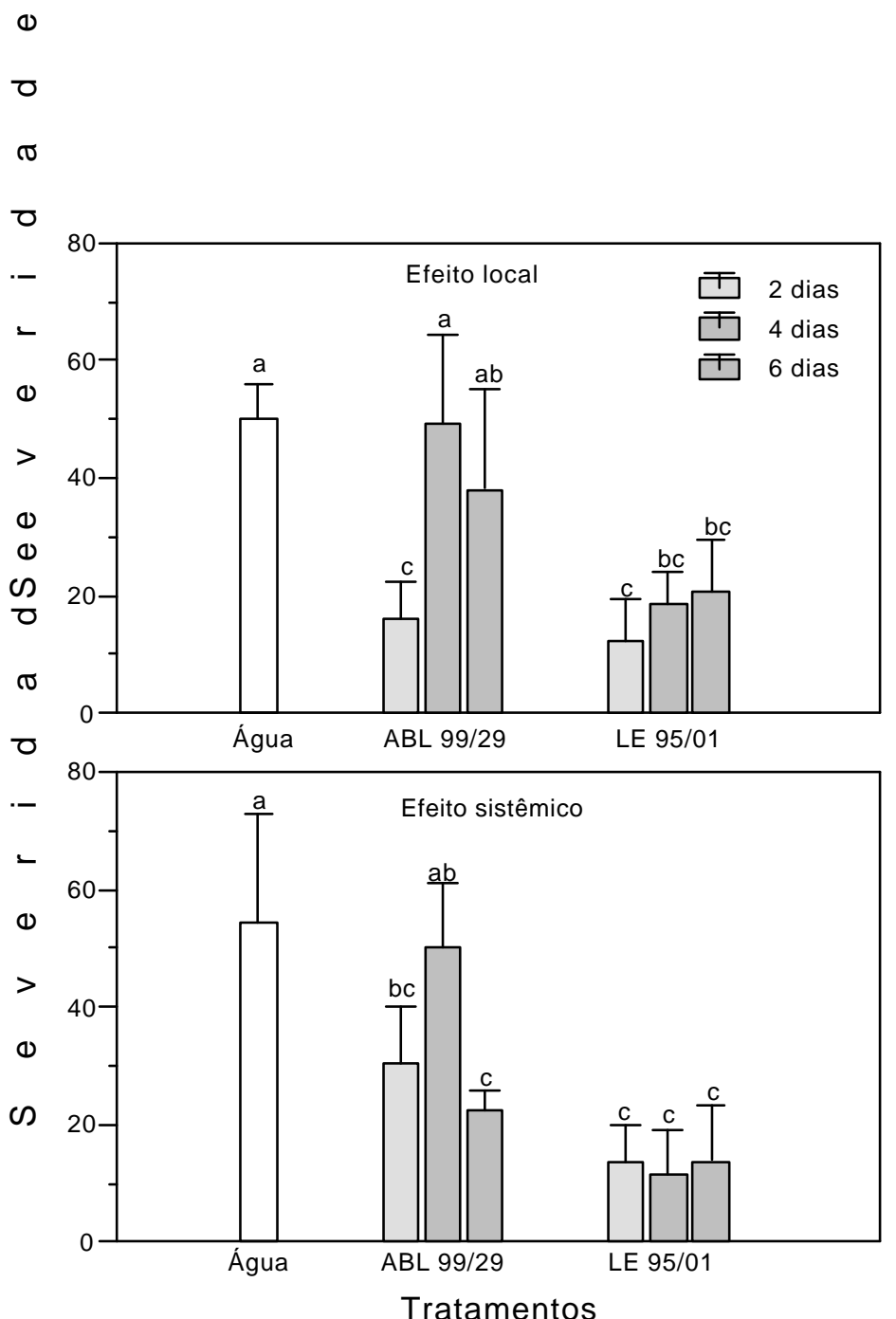

Figura 5 - Influência do intervalo de tempo entre o tratamento das plantas de pepino com extratos de basidiocarpos dos isolados ABL 99/29 de A. blazei e LE 95/01 de L. edodes e a inoculação com Colletotrichum lagenarium $\left(5 \times 10^{4}\right.$ esporos $\left./ \mathrm{mL}\right)$. Extratos aplicados a $20 \%(\mathrm{v} / \mathrm{v})$. As barras representam a média \pm desviopadrão. Médias seguidas pelas mesmas letras não diferem entre si pelo teste de Tukey a $5 \%$ 


\section{$\underset{\widetilde{\sigma}}{\varepsilon}$}

\subsubsection{Efeito in vitro dos extratos de basidiocarpos sobre $C$. lagenarium}

Alguns extratos de shiitake, incorporados em BDA a 5\%, reduziram o crescimento micelial do patógeno (Figura 6). Os isolados cujos extratos mostraram tal efeito foram o LE 96/17 (cultivado em E. saligna) e o LE 96/22. No entanto, o efeito, apesar de significativo estatisticamente, foi pouco pronunciado. A $10 \%$, não houve efeito dos extratos de L. edodes, bem como de A. blazei sobre o crescimento micelial do fitopatógeno (Figura 7).

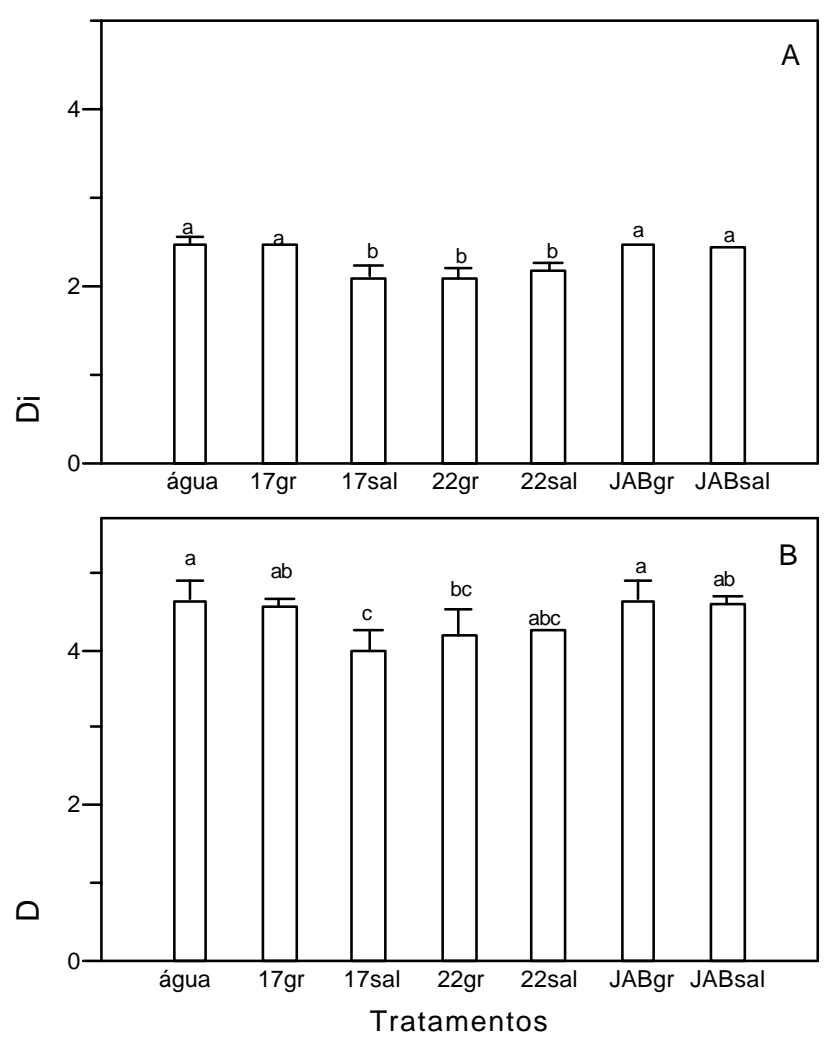

Figura 6 - Efeito dos extratos aquosos de basidiocarpos dos isolados LE 96/17, LE 96/22 e LE JAB-K, incorporados a $5 \%$ em BDA, no crescimento micelial de Colletotrichum lagenarium. Avaliações realizadas aos 4 dias (A) e aos 8 dias (B) após a repicagem do patógeno. gr = basidiocarpos obtidos em Eucalyptus grandis; sal = obtidos em E. saligna. As barras representam a média \pm desviopadrão. Médias seguidas pelas mesmas letras não diferem entre si pelo teste de Tukey a $5 \%$ 

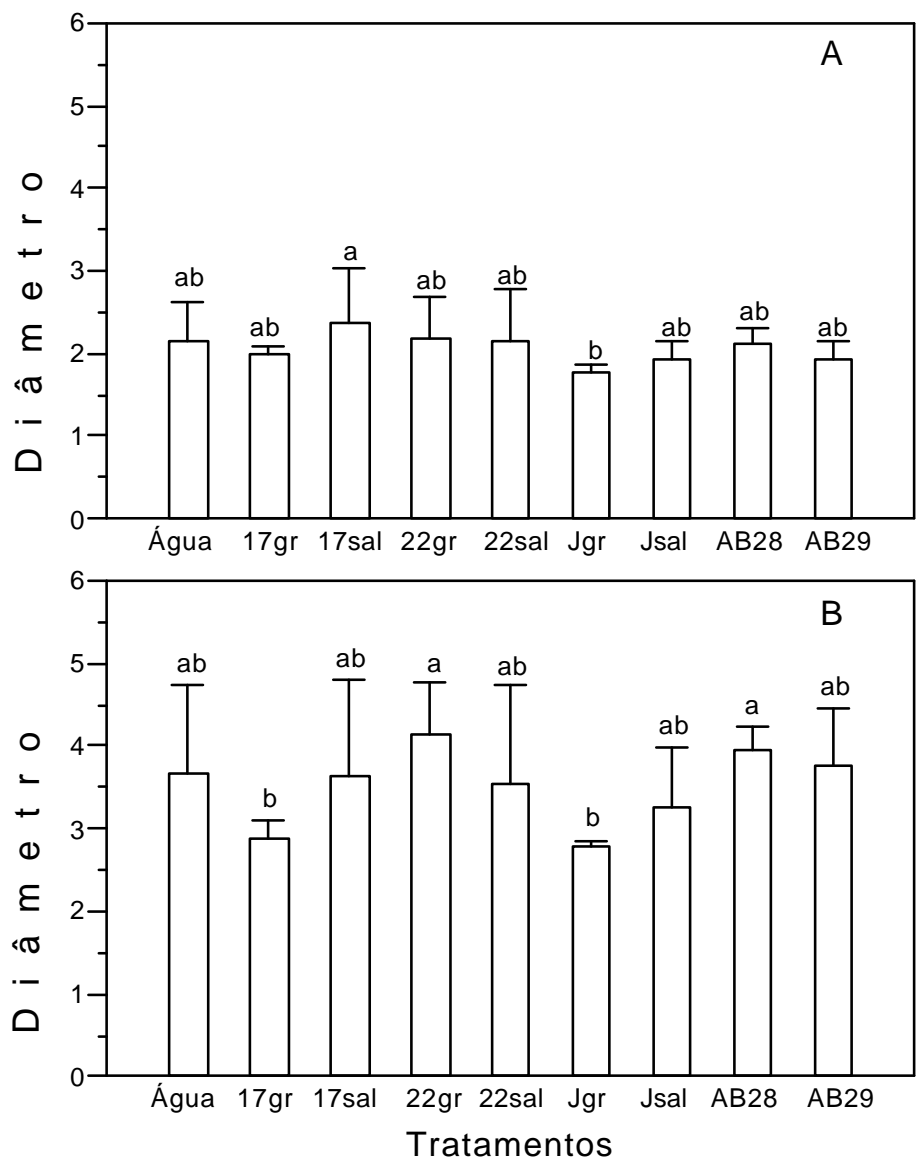

Figura 7 - Efeito dos extratos aquosos de basidiocarpos dos isolados LE 96/17, LE 96/22 e LE JAB-K de L. edodes, e dos isolados ABL 99/28 e ABL 99/29 de A. blazei, incorporados a $10 \%$ em BDA, no crescimento micelial de Colletotrichum lagenarium. Avaliações realizadas aos 4 dias (A) e aos 8 dias (B) após a repicagem do patógeno. gr = basidiocarpos obtidos em Eucalyptus grandis; sal = obtidos em E. saligna. As barras representam a média \pm desviopadrão. Médias seguidas pelas mesmas letras não diferem entre si pelo teste de Tukey a $5 \%$ 
Os extratos de basidiocarpos dos cogumelos, principalmente os de A. blazei, estimularam a germinação in vitro de esporos de C. lagenarium, em termos percentuais (Tabela 1), e provocaram aumento no comprimento do tubo germinativo desses esporos em relação aos que germinaram no tratamento controle. Em função desses resultados, a redução na formação de apressórios provocada pelos extratos (Tabela 1) pode ser interpretada mais como uma conseqüência da alta disponibilidade de nutrientes nos tratamentos do que como uma ação antifúngica.

Tabela 1. Efeito dos extratos aquosos de basidiocarpos dos isolados LE 95/01 e LE 96/22 de Lentinula edodes, e dos isolados ABL 97/11 e ABL 99/29 de Agaricus blazei, utilizados a $10 \%$ e a $20 \%$ (v/v), na germinação de esporos e formação de apressórios de Colletotrichum lagenarium

\begin{tabular}{|c|c|c|}
\hline Tratamento & Germinação de esporos (\%) & Formação de apressórios (\%) \\
\hline Água & $59,2 \pm 11,0 \quad \mathrm{~d}$ & $88,0 \pm 6,2 \mathrm{a}$ \\
\hline LE 95/01 (10\%) & $77,8 \pm 8,7 \mathrm{abc}$ & $5,1 \pm 1,1 \quad \mathrm{~cd}$ \\
\hline LE 95/01 (20\%) & $65,0 \pm 4,1 \quad \mathrm{~cd}$ & 0 \\
\hline LE 96/22 (10\%) & $72,8 \pm 8,3 \quad b c$ & $4,1 \pm 1,2 \quad \mathrm{~cd}$ \\
\hline LE 96/22 (20\%) & $60,2 \pm 4,1 \quad \mathrm{~cd}$ & $\mathrm{~d}$ \\
\hline ABL 97/11 (10\%) & $85,8 \pm 2,8 \mathrm{abc}$ & $18,2 \pm 5,9 \mathrm{abc}$ \\
\hline ABL 97/11 (20\%) & $82,8 \pm 2,7 \mathrm{ab}$ & d \\
\hline ABL 99/29 (10\%) & $86,4 \pm 5,2 \mathrm{a}$ & $21,2 \pm 8,7 b$ \\
\hline ABL 99/29 (20\%) & $79,6 \pm 2,7 a b$ & $6,6+2,5 \mathrm{bcd}$ \\
\hline
\end{tabular}

Médias \pm desvio-padrão, seguidas pelas mesmas letras, na coluna, não diferem entre si pelo teste de Tukey a $5 \%$ 


\subsubsection{Determinação da atividade de proteínas relacionadas à patogênese em plantas de pepino}

A aplicação do extrato aquoso de basidocarpos de L. edodes em pepino provocou um acúmulo local e sistêmico de peroxidases e quitinases, mas não de glucanases (Figuras 8, 9 e 10).

$\mathrm{O}$ acúmulo local de peroxidases induzido por shiitake foi observado no $3^{\circ}$ e $6^{\circ}$ dias após o tratamento, ficando bem evidente no $9^{\circ}$ dia, enquanto o acúmulo sistêmico foi observado somente no $12^{\circ}$ dia após o tratamento com shiitake (Figura 8). Plantas tratadas com shiitake e posteriormente inoculadas com $C$. lagenarium acumularam peroxidases de forma muito semelhante às tratadas apenas com shiitake. Folhas que foram apenas inoculadas com $C$. lagenarium acumularam peroxidases mais tardiamente em relação às que receberam shiitake (Figura 8 - Acúmulo local). O nível de peroxidases não foi alterado nas plantas tratadas apenas com água durante todo o período de amostragem (12 dias).

As quitinases também foram acumuladas local e sistemicamente nas plantas tratadas com shiitake até o $6^{\circ}$ dia após o tratamento. No entanto, após a inoculação com C. lagenarium, não houve mais diferenças significativas entre quaisquer dos tratamentos (Figura 9). Em termos de glucanases, não se obtiveram diferenças significativas entre os tratamentos nos períodos amostrados, tanto em folhas tratadas (efeito local) quanto sistemicamente (Figura 10). Os experimentos com quitinases e glucanases foram realizados por duas vezes e mostraram as mesmas tendências.

Ao contrário de L. edodes, o isolado ABL 99/29 de A. blazei não promoveu o acúmulo de peroxidases em pepino nos primeiros dias após o tratamento das plantas com extrato de basidiocarpos a $20 \%$ (v/v). O acúmulo, local e sistêmico, foi observado na última data de amostragem, aos 12 dias após o tratamento (Figura 11). 

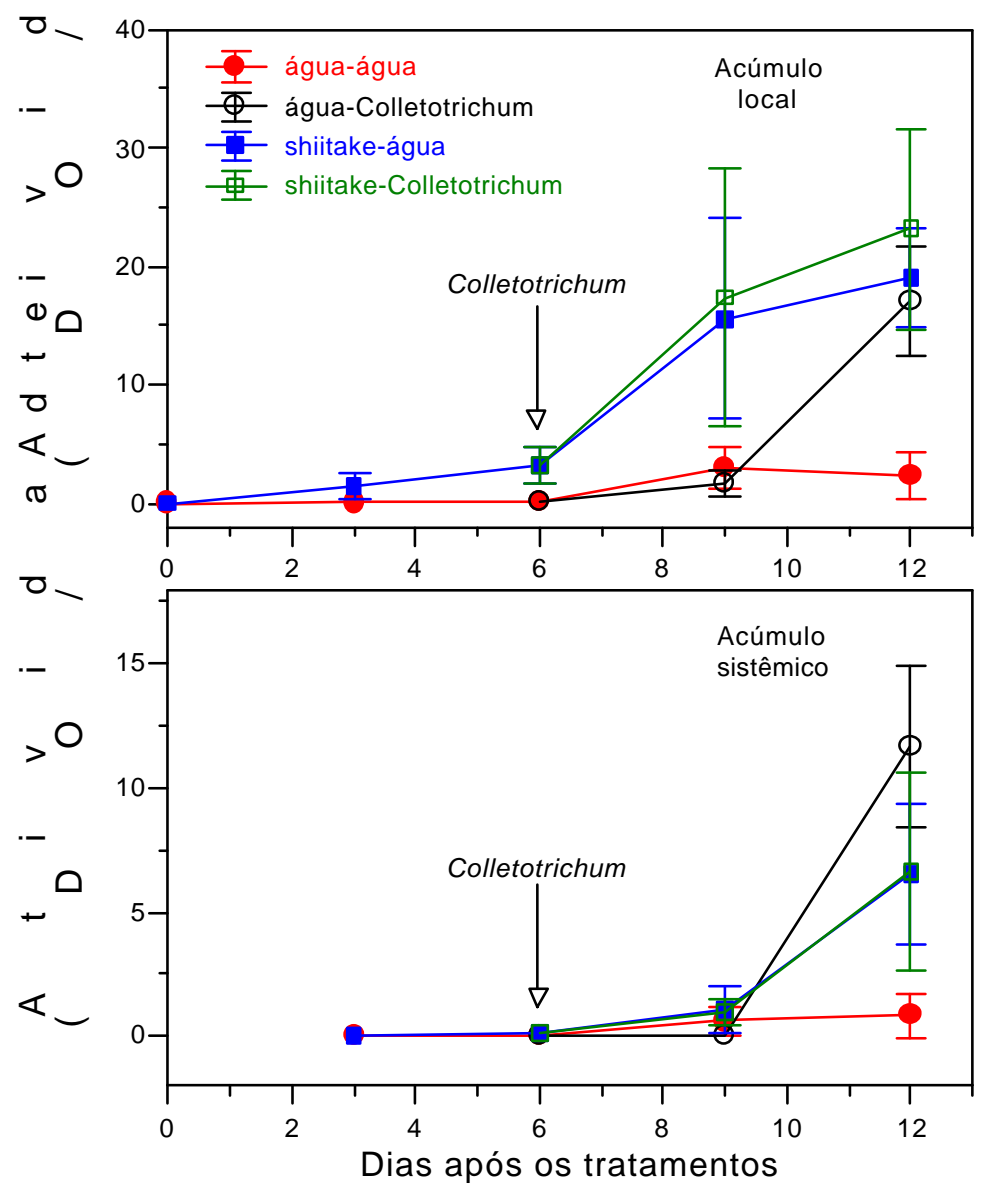

Figura 8 - Efeito da aplicação do extrato aquoso de basidiocarpos de Lentinula edodes (mistura dos isolados LE 96/17 e LE 96/22) sobre a atividade de peroxidases em folhas de pepino. A seta indica o momento da inoculação, com Colletotrichum lagenarium, de parte das plantas tratadas com água ou com shiitake (a parte restante das plantas recebeu água no lugar do patógeno, conforme legenda). Barras representam a média \pm desvio padrão 


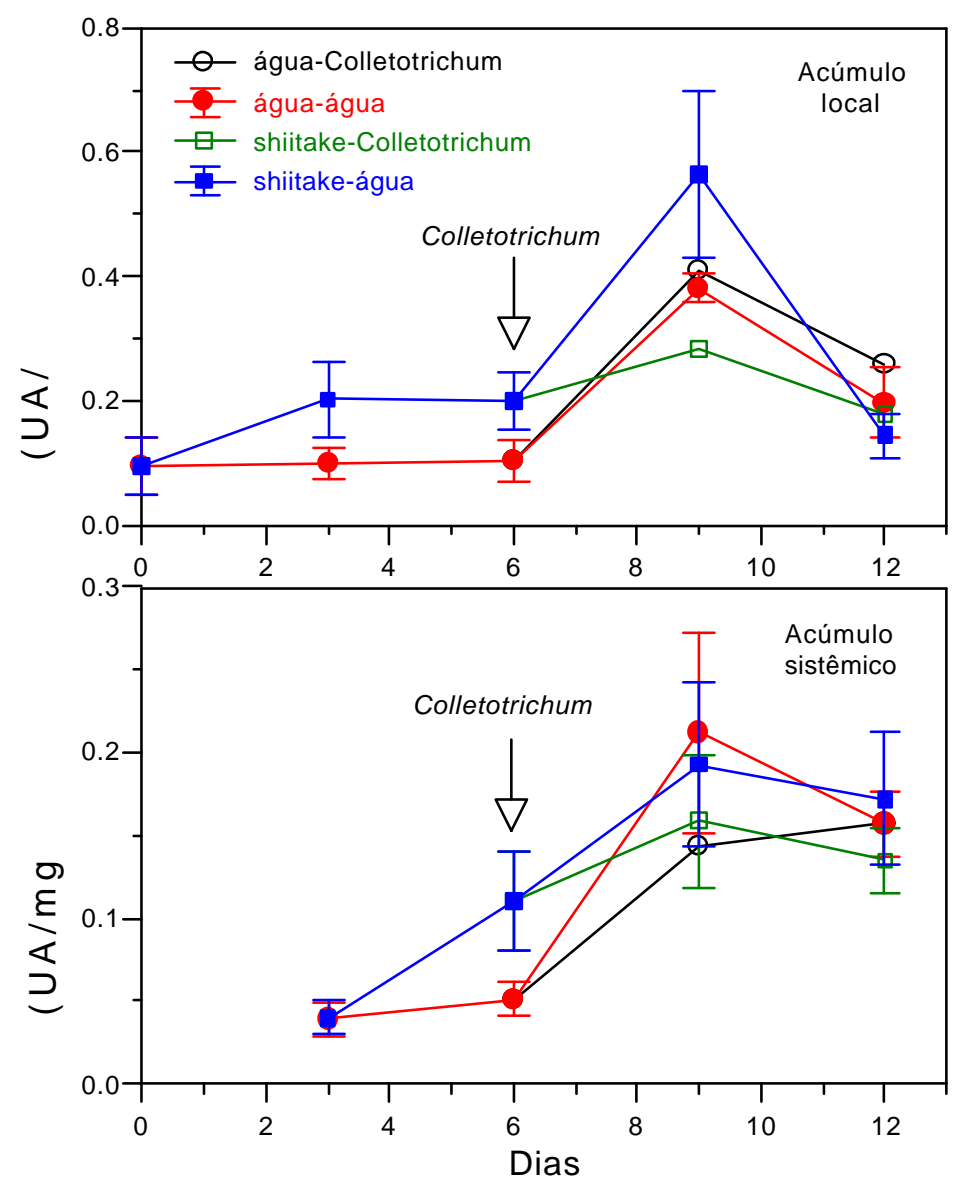

Figura 9 - Efeito da aplicação do extrato aquoso de basidiocarpos de Lentinula edodes (mistura dos isolados LE 96/17 e LE 96/22) sobre a atividade de quitinases em folhas de pepino. A seta indica o momento da inoculação, com Colletotrichum lagenarium, de parte das plantas tratadas com água ou com shiitake (a parte restante das plantas recebeu água no lugar do patógeno, conforme legenda). Barras representam a média \pm desvio padrão 
․ㅗ
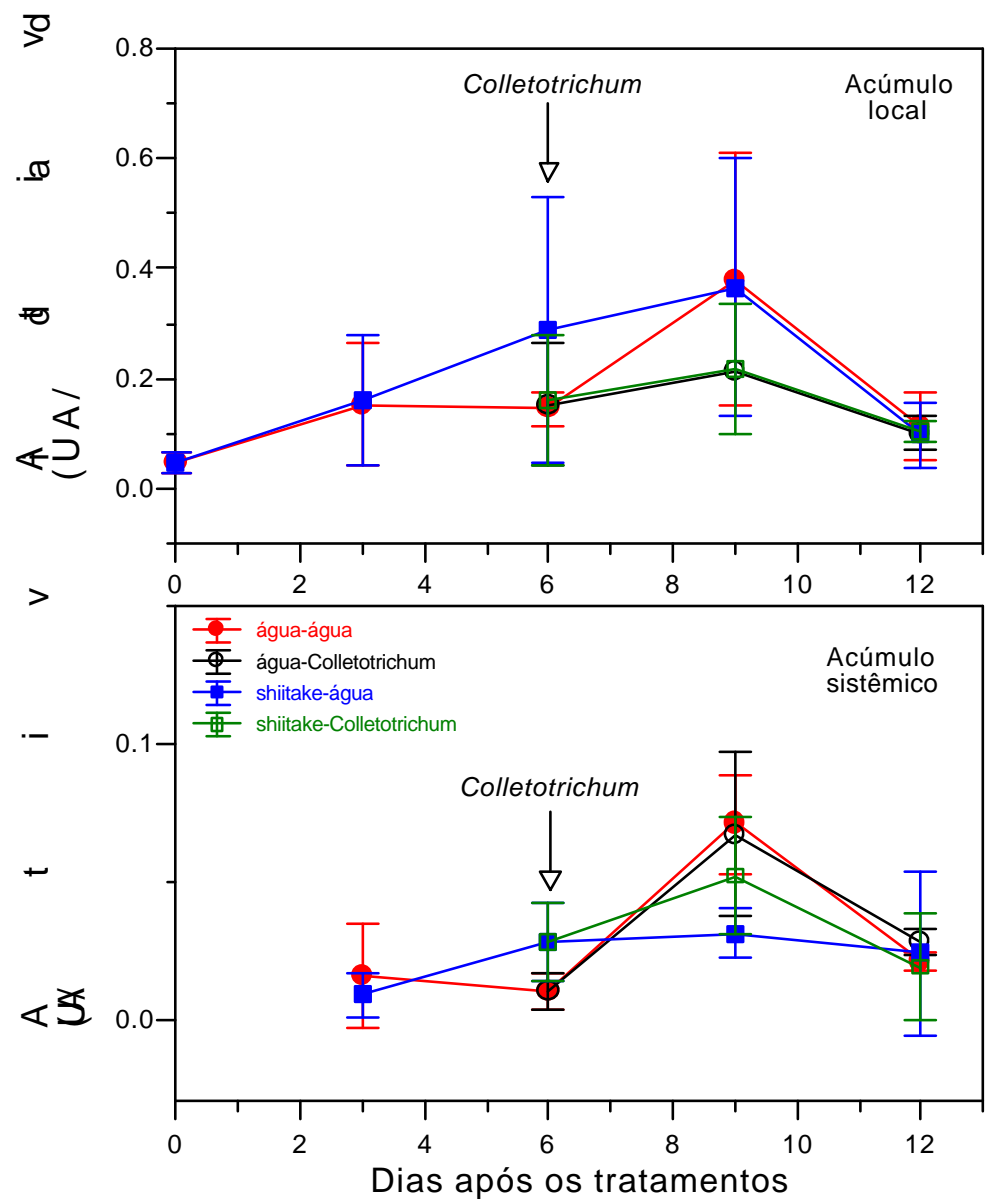

Figura 10 - Efeito da aplicação do extrato aquoso de basidiocarpos de Lentinula edodes (mistura dos isolados LE 96/17 e LE 96/22) sobre a atividade de glucanases em folhas de pepino. A seta indica o momento da inoculação, com Colletotrichum lagenarium, de parte das plantas tratadas com água ou com shiitake (a parte restante das plantas recebeu água no lugar do patógeno, conforme legenda). Barras representam a média \pm desvio padrão 
$\varpi$

ర
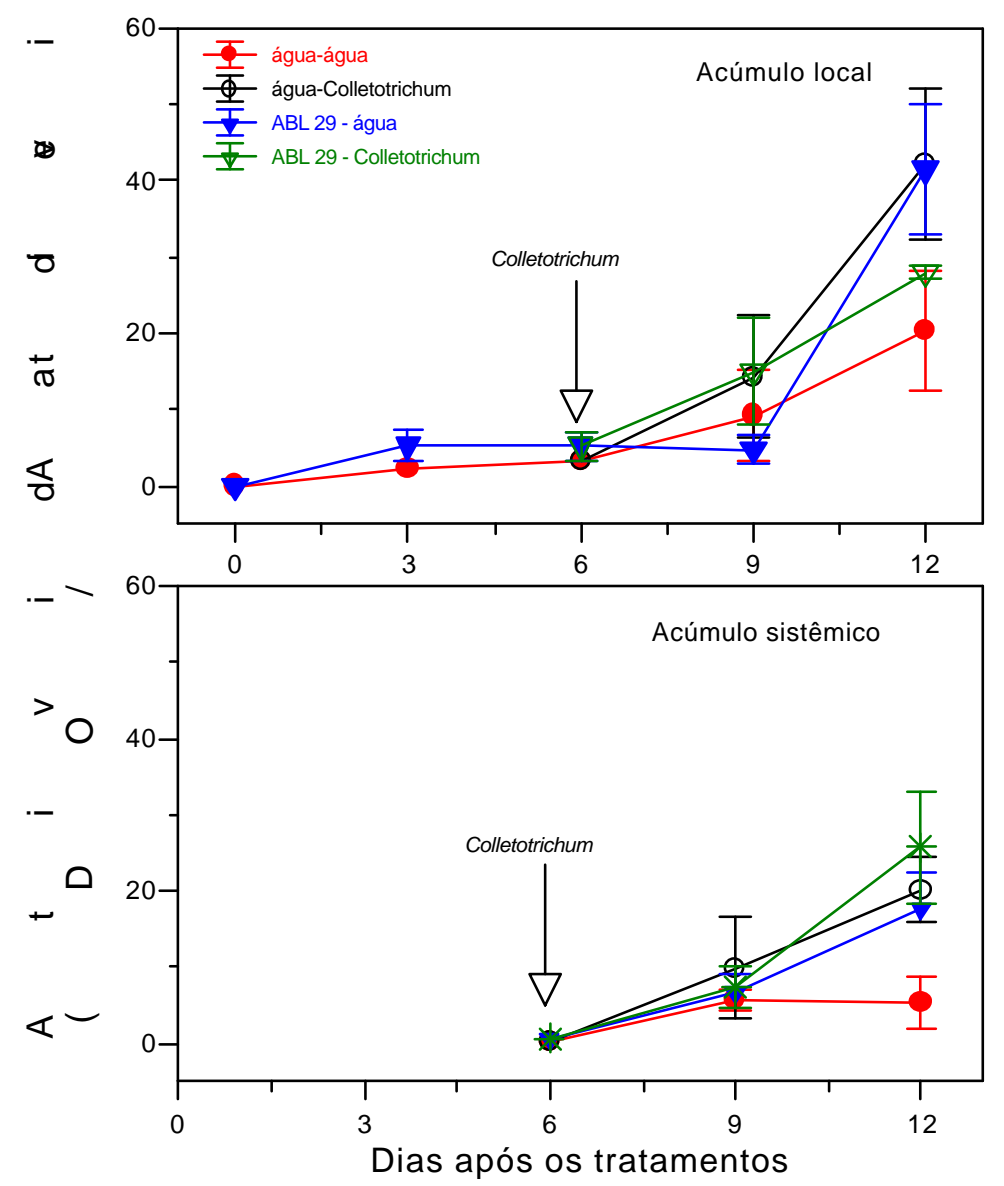

Figura 11 - Efeito da aplicação do extrato aquoso de basidiocarpos de Agaricus blazei (ABL 99/29) sobre a atividade de peroxidases em folhas de pepino. A seta indica o momento da inoculação, com Colletotrichum lagenarium, de parte das plantas tratadas com água ou com A. blazei (a parte restante das plantas recebeu água no lugar do patógeno, conforme legenda). Barras representam a média \pm desvio padrão

\subsubsection{Efeito dos extratos aquosos de basidiocarpos de A. blazei e L. edodes no desenvolvimento das plantas de pepino}

Estudando a ação dos extratos de basidiocarpos sobre o desenvolvimento das plantas de pepino, não foram encontrados efeitos deletérios sobre a altura e área foliar 
das plantas, 20 dias após a realização dos tratamentos. Pelo contrário, houve uma tendência em estimular o crescimento das plantas (Tabela 2).

Tabela 2. Efeito dos extratos aquosos de basidiocarpos dos isolados LE 96/22 de Lentinula edodes e ABL 99/29 de Agaricus blazei, utilizados a 10\% (v/v), no desenvolvimento das plantas de pepino. As avaliações foram realizadas 20 dias após os tratamentos

\begin{tabular}{llc}
\hline Tratamento & Altura $(\mathrm{cm})$ & Área foliar total $\left(\mathrm{cm}^{2}\right)$ \\
\hline Água & $67,2 \pm 6,9 \mathrm{a}$ & $463,6 \pm 84,0 \mathrm{ab}$ \\
Água - Colletotrichum $^{*}$ & $58,6 \pm 11,0 \mathrm{a}$ & $377,0 \pm 14,0 \mathrm{a}$ \\
LE 96/22 & $67,2 \pm 8,3 \mathrm{a}$ & $518,4 \pm 136 \mathrm{ab}$ \\
LE 96/22 - Colletotrichum & $63,2 \pm 7,8 \mathrm{a}$ & $366,0 \pm 64,0 \mathrm{a}$ \\
ABL 99/29 & $74,8 \pm 4,8 \mathrm{a}$ & $622,2 \pm 117,2 \mathrm{~b}$ \\
ABL 99/29 - Colletotrichum & $68,0 \pm 7,2 \mathrm{a}$ & $448,6 \pm 51,8 \mathrm{ab}$ \\
ASM** & $71,7 \pm 13,0 \mathrm{a}$ & $450,0 \pm 148 \mathrm{ab}$ \\
ASM - Colletotrichum & $71,8+8,7 \mathrm{a}$ & $460,4+97,5 \mathrm{ab}$
\end{tabular}

* Plantas tratadas com água nas segundas folhas verdadeiras e, 7 dias depois, inoculadas com $C$. lagenarium nas segundas e terceiras folhas

** Acibenzolar S-metil, utilizado a 50 ppm

Médias \pm desvio padrão, seguidas pelas mesmas letras, na coluna, não diferem entre si pelo teste de Tukey a $5 \%$

\subsection{Discussão}

Os extratos aquosos de basidiocarpos dos cogumelos L. edodes e A. blazei protegeram as plantas de pepino contra $C$. lagenarium. A proteção foi dependente da concentração de extrato utilizada. Os isolados LE 95/01, LE 96/17, LE 96/22 e LE JAB$\mathrm{K}$ de shiitake reduziram a severidade da antracnose local e sistemicamente, a partir da dose de $10 \%$ (v/v) de extrato, enquanto que para os isolados ABL 97/11 e ABL 99/29 de A. blazei, de maneira geral, o efeito sistêmico ficou mais evidente na concentração de 
$20 \%$ (v/v). A 10\%, a proteção conferida pelos extratos de A. blazei foi predominantemente local.

A dependência da dose do indutor para a proteção contra a antracnose já havia sido verificada por Gottstein \& Kuc (1989) utilizando solução de $\mathrm{K}_{3} \mathrm{PO}_{4}$, onde se demonstrou que as concentrações do sal inferiores a $10 \mathrm{mM}$ não proporcionaram reduções significativas na doença. De modo similar, a resistência induzida pela bactéria Pseudomonas syringae pv. lachrymans contra $C$. lagenarium foi efetiva em várias cultivares de pepino e apresentou correlação positiva com a concentração bacteriana utilizada como indutor (Caruso \& Kuc, 1979).

Com relação ao intervalo de tempo entre o tratamento das plantas com os extratos dos cogumelos e a inoculação com o fitopatógeno, houve pouca influência do mesmo no controle da antracnose. Esse resultado poderia conduzir a um questionamento da participação da resistência sistêmica adquirida no processo, já que é sabido que o fenômeno necessita de um tempo mínimo para ocorrer, tempo esse necessário para geração e translocação de sinais até as partes da planta não diretamente tratadas. No entanto, Ishii et al. (1999) demonstraram que acibenzolar-S-metil (ASM), o primeiro indutor de resistência disponível comercialmente, protegeu sistemicamente pepino contra $C$. lagenarium em um intervalo tão curto quanto 3 horas, e o nível de proteção alcançado (95\%) foi comparável ao obtido quando o ASM foi aplicado 7 dias antes da inoculação com o fitopatógeno. Testes in vitro evidenciaram a ausência de efeito do ASM sobre o crescimento micelial, bem como sobre a germinação e o comprimento do tubo germinativo de $C$. lagenarium.

Estudando o mecanismo de ação no controle da antracnose, os extratos de $L$. edodes desencadearam um acúmulo nas atividades de peroxidases e quitinases. As peroxidases participam do processo de lignificação de células vegetais, sendo requeridas para a polimerização final de compostos fenólicos junto à lignina. A lignificação, dessa forma, pode afetar o desenvolvimento fúngico por bloquear fisicamente o crescimento do haustório, reduzir a difusão de nutrientes para o fungo ou levar à síntese de precursores de lignina tóxicos ao fungo. Por sua vez, as quitinases podem atuar diretamente na quitina presente na parede fúngica, assim como apresentar um efeito 
indireto contra o patógeno, pela liberação de fragmentos da parede celular que vão elicitar outras respostas de defesa na planta.

Os resultados revelaram que, em termos locais (folhas tratadas), L. edodes foi mais eficiente do que o fitopatógeno em induzir o acúmulo de peroxidases. Os níveis de peroxidases nas folhas tratadas com shiitake no $6^{\circ}$ e $9^{\circ}$ dias após o tratamento $(0$ e 3 dias após a inoculação com $C$. lagenarium, respectivamente) podem ter contribuído para a redução na severidade da doença que, no experimento considerado foi de $60 \% \mathrm{em}$ relação ao controle (dados não mostrados). Por outro lado, o acúmulo sistêmico de peroxidases desencadeado pelo shiitake foi tardio em relação ao momento da inoculação com o fitopatógeno, de modo que na porcentagem de proteção sistêmica encontrada (70\%), permanece não esclarecida a participação dessas enzimas.

Por sua vez, o nível de quitinases presente nas plantas tratadas com L. edodes no sexto dia (dia da inoculação com o fitopatógeno), significativamente maior que aquele presente nas plantas tratadas com água, pode ter auxiliado na defesa da planta. Conforme Schneider \& Ullrich (1994), a resistência de uma planta pode necessitar de uma atividade mínima de enzimas relacionadas à defesa no momento da infecção, e que níveis enzimáticos superiores, desenvolvidos posteriormente, são inefetivos. Inclusive, após a infecção, não está claro se o aumento dessas e de outras enzimas de defesa está relacionado à resistência ou meramente à expressão de sintomas (Ji \& Kuc, 1997).

Após a inoculação com $C$. lagenarium, plantas pré-tratadas com shiitake tenderam a ter diminuição na atividade de quitinases em comparação àquelas tratadas com shiitake que não foram posteriormente inoculadas (Figura 9). Embora sem saber o porquê desta diminuição, resultados semelhantes foram encontrados por Schneider \& Ullrich (1994) com quitinases e glucanases em plantas de pepino tratadas com extratos de Reynoutria sachalinensis e posteriormente inoculadas com Sphaerotheca fuliginea (agente causal do oídio) e também por Reuveni et al. (1997) com peroxidases e glucanases em pepino tratado com soluções de micronutrientes e inoculado com $S$. fuliginea algum tempo depois.

Quanto às glucanases, o cogumelo shiitake não provocou o aumento na atividade dessas enzimas. Dalisay \& Kuc (1995) também não encontraram correlação entre 
resistência em plantas de pepino e acúmulo de glucanases totais pelo agente indutor. No entanto, Ji \& Kuc (1995) mostraram que uma isoforma acídica de $\beta$-1,3-glucanase participa da resistência sistêmica em pepino.

O trabalhos de Hammershmidt \& Kuc (1982), Dean \& Kuc (1987), Conti et al. (1994), entre outros, mostraram que agentes indutores de resistência em pepino provocam rápida lignificação da parede de células epidermais do hospedeiro que venham a entrar em contato com o fitopatógeno, o que está associado a aumentos na atividade de peroxidases, de forma que essas enzimas são apontadas, em muitos casos, como um marcador bioquímico da resistência induzida nessa espécie vegetal.

Entretanto, alguns indutores de resistência em pepino não elevam significativamente o nível de peroxidases na magnitude da proteção induzida, a exemplo do que ocorreu em plantas tratadas com extratos de $R$. sachalinensis (Schneider \& Ullrich, 1994). Nesse trabalho, vários indutores bióticos e abióticos elevaram as atividades de quitinases, $\beta$-1,3-glucanases, além das peroxidases, mas sem haver relação entre o aumento de atividade de uma enzima em particular e a indução de resistência, o que reforça a hipótese de que a resistência é um processo multi-componente.

Independente das dificuldades em se indicar o nível de participação de um mecanismo específico na proteção de uma planta, o fato de L. edodes (shiitake) estar desencadeando local e sistemicamente o acúmulo de duas enzimas relacionadas à defesa (peroxidases e quitinases) em pepino, sugere que o controle da antracnose observado é, pelo menos em parte, devido à ação do extrato de basidiocarpos na planta.

A ativação de mecanismos de defesa nas plantas de pepino por parte dos cogumelos estudados, a sistemicidade no controle da antracnose e a ausência de efeitos negativos sobre o crescimento vegetativo e sobre a germinação de esporos de $C$. lagenarium apontam a indução de resistência como o principal modo de ação para o controle da antracnose por parte de L. edodes e A. blazei. Uma desvantagem comentada para esse modo de ação é o provável gasto energético da planta, direcionando o metabolismo para a defesa, e comprometendo o desenvolvimento normal. Entretanto, esse não foi o caso com os extratos de basidiocarpos, os quais não mostraram efeitos deletérios sobre plantas de pepino crescidas em casa de vegetação, quando o tratamento 
das mesmas se deu no estádio de três folhas verdadeiras. Dessa forma, o presente estudo demonstrou o potencial dos cogumelos L. edodes e A. blazei para induzir resistência em plantas de pepino contra o agente causal da antracnose.

\subsection{Conclusões}

Os extratos aquosos de basidiocarpos dos cogumelos L. edodes e A. blazei reduzem a severidade da antracnose em plantas de pepino, dependendo da concentração utilizada. A proteção obtida envolveu a indução de resistência. 


\section{PURIFICAÇÃO PARCIAL DE ELICITORES DE PEROXIDASES EM PLÂNTULAS DE PEPINO, ISOLADOS A PARTIR DE Lentinula edodes, COM ATIVIDADE PROTETORA CONTRA Colletotrichum lagenarium}

\section{Resumo}

O cogumelo shiitake (Lentinula edodes) vem sendo utilizado em pesquisas envolvendo o controle de doenças em humanos e em vegetais. Em plantas de pepino tratadas com extrato aquoso de basidiocarpos do cogumelo, houve redução na severidade da antracnose, provocada por Colletotrichum lagenarium, e aumento na atividade de peroxidases nas folhas. Com o objetivo de obter moléculas de interesse agronômico, no tocante à proteção de plantas, o extrato aquoso bruto do basidiocarpo de L. edodes foi fracionado com sulfato de amônio. A fração correspondente a 40-80\% de saturação (p40-80) foi a mais efetiva em reduzir a antracnose em cotilédones de pepino, sendo então submetida à cromatografia de troca aniônica (CTA). Após a CTA, seis picos protéicos foram obtidos, e o pico $\mathrm{V}$, contendo em média $25 \%$ das proteínas presentes em p40-80, provocou o acúmulo de peroxidases nos cotilédones de pepino em dois bioensaios independentes, e reduziu a antracnose em um dos ensaios. A separação eletroforética das proteínas do pico $\mathrm{V}$ revelou a presença de mais de uma banda no gel. Dessa forma, obteve-se uma purificação parcial de elicitores presentes no basidiocarpo de L. edodes.

\section{Summary}

The shiitake mushroom (Lentinula edodes) has been used in research involving the control of human and plant diseases. In cucumber plants treated with aqueous extracts from mushroom fruiting bodies, there was a reduction in anthracnose severity, 
caused by Colletotrichum lagenarium, and an increase in peroxidase activity in the leaves. With the aim of obtaining molecules of agronomic interest, the crude aqueous extract from L. edodes fruiting body was fractioned with ammonium sulfate. The fraction corresponding to $40-80 \%$ of saturation (p40-80), the most effective in reducing anthracnose on cucumber cotyledons, was submitted to anion exchange chromatography (AEC). After AEC, six protein peaks were obtained and peak $\mathrm{V}$, containing $25 \%$ average of the proteins present in $\mathrm{p} 40-80$, induced a peroxidase increase in the cucumber cotyledons in two independent bioassays, and also reduced the anthracnose in one of the tests. Separation of peak V proteins by SDS-gel electrophoresis revealed the presence of more than a band in the gel. Thus, a partial purification of elicitors present in the $L$. edodes fruiting body was obtained.

\subsection{Introdução}

Elicitores (ou eliciadores) são moléculas que estimulam alguma resposta de defesa nas plantas. Isso ocorre após se ligarem a receptores vegetais, localizados muitas vezes na membrana plasmática das células, desencadeando uma transdução de sinais que conduzirá à ativação de um ou mais mecanismos de defesa. Os primeiros elicitores a serem caracterizados foram os oligossacarídeos fúngicos, incluindo fragmentos da parede celular como hepta- $\beta$-glucosídeo, oligoquitina e oligoquitosana (Hahn, 1996).Glucanas, com a habilidade de induzir o acúmulo das fitoalexinas gliceolinas em tecidos de soja, foram primeiramente detectadas em filtrados de cultura de Phytophthora sojae, um oomiceto fitopatogênico (Ayers et al., 1976b). A falta de afinidade do elicitor pela resina de troca aniônica DEAE-celulose, a forte ligação à resina de troca aniônica AG 1-X1 em pH 10, juntamente com cromatografia de exclusão molecular formaram a base para a purificação do elicitor. Posteriormente, Ayers et al. (1976a) obtiveram elicitores liberados das paredes das hifas de $P$. sojae, após autoclavagem das mesmas em meio aquoso, os quais foram caracterizados como glucanas.

A interação entre soja e o elicitor tipo $\beta$-glucana presente em $P$. sojae tem sido melhor caracterizada. $\mathrm{O}$ primeiro evento entre a soja e o oomiceto é o ataque da parede celular do microrganismo por $\beta$-1,3-glucanases da soja, resultando na liberação de $\beta$ - 
glucanas ativas, que então iniciam o acúmulo de fitoalexinas nas plantas. O menor elicitor do patógeno foi determinado como sendo um hepta- $\beta$-glucosídio, e o elicitor sintetizado quimicamente induziu não só o acúmulo de fitoalexinas, mas apresentou alta afinidade por frações da membrana plasmática de soja, supostamente contendo proteínas receptoras (Cheong et al., 1991).

A partir de urediniosporos autoclavados de Hemileia vastatrix, foi isolado um outro elicitor da síntese de gliceolinas em soja. O procedimento de purificação envolveu precipitação etanólica fracionada, seguida de cromatografias em Concanavalina ASepharose 4B, DEAE-celulose e Bio-Gel P-60. A substância elicitora não apresentou afinidade pela lectina (Con A) e pelo trocador aniônico (DEAE-celulose), mostrou-se solúvel em água, termoestável, resistente ao tratamento com pronase e susceptível ao tratamento com metaperiodato de sódio, sugerindo tratar-se de um polissacarídeo. $\mathrm{O}$ principal componente do elicitor obtido foi a manose, seguida por glicose e galactose (Guzzo \& Moraes, 1997).

Quitina, um polímero linear de $\mathrm{N}$-acetil- $\beta$-1,4-glucosamina, é o principal constituinte de natureza polissacarídica das paredes miceliais, incluindo as de muitos fungos fitopatogênicos, e também apresenta atividade elicitora. Respostas de defesa induzidas por quitina incluem lignificação em folhas de trigo (Pearce \& Ride, 1982), e aumento na atividade de enzimas do caminho da biossíntese de fitoalexinas em arroz (Ren \& West, 1992). Por sua vez, quitosana, um polímero de $\beta$-1,4-glucosamina, obtido a partir de quitina desacetilada, provocou um aumento na atividade de quitinases e glucanases em folhas de amendoim (Sathiyabama \& Balasubramanian, 1998), estimulou a síntese de compostos fenólicos e lignina em plântulas de trigo após o tratamento das sementes (Bhaskara et al., 1999), e sensibilizou plantas de tomate a responder mais rapidamente a Fusarium oxysporum f. sp. radicis-lycopersici, pelo depósito de materiais ricos em fenóis nos espaços intercelulares e pela oclusão de vasos do xilema com tiloses, em tecidos radiculares (Lafontaine \& Benhamou, 1996).

Outros elicitores microbianos são glicoproteínas. Em Puccinia graminis f. sp. tritici, um elicitor glicoprotéico foi purificado a partir das paredes celulares e também do fluido apoplástico presente em folhas de trigo infectadas. A porção carboidrato da 
molécula é a responsável pela atividade elicitora, o que foi demonstrado pela perda da atividade quando da oxidação por periodato (Beissmann \& Reisener, 1990). Já em elicitores glicoprotéicos derivados de levedura, tanto a porção glicana quanto a porção peptídica são importantes para induzir a biossíntese de fenilalanina amônia-liase em células de tomate em suspensão, apresentando-se como mais ativos os glicopeptídeos que contêm de dez a doze resíduos manosil (Grosskopf et al., 1991).

Moléculas elicitoras do acúmulo de fitoalexinas em sorgo, provavelmente glicoproteínas, termoestáveis, solúveis em etanol 50\%, apresentando massa molecular de 18,4 a $25 \mathrm{kDa}$ e afinidade por DEAE-Celulose, foram obtidas a partir da autoclavagem de uma suspensão de células de Saccharomyces cerevisae. As frações fortemente ligadas ao trocador aniônico apresentaram maior atividade elicitora em relação às mais fracamente ligadas, enquanto que algumas frações sem afinidade por DEAE-celulose atuaram como supressoras. A atividade biológica foi reduzida após o tratamento com proteinase, mostrando a importância da porção protéica nas moléculas elicitoras (Wulff \& Pascholati, 1999), de forma análoga ao obtido no trabalho de Grosskopf et al. (1991) com elicitores derivados de levedura ativos em tomate.

Recentemente, polipeptídeos biologicamente ativos em plantas têm sido purificados e caracterizados. Um elicitor protéico, obtido inicialmente da parede das hifas de $P$. sojae, e purificado a partir do filtrado de cultura do oomiceto, induziu a síntese de fitoalexinas em plantas de salsa. A atividade do elicitor reside na porção polipeptídica de uma glicoproteína de $42 \mathrm{kDa}$, sensível à digestão por protease e insensível à deglicosilação (Parker et al., 1991). Um cDNA codificando o elicitor foi clonado a partir de $P$. sojae, e demonstrou-se que a sequiência de aminoácidos requerida para a atividade elicitora está localizada no terço carboxi-terminal da proteína (Sacks et al., 1995).

Elicitinas são uma família de pequenas proteínas altamente conservadas, produzidas por muitas espécies de Phytophthora. Quando aplicadas em fumo, essas proteínas elicitaram a formação de necrose nos tecidos tratados e a síntese de proteínas relacionadas à patogênese, induzindo resistência contra $P$. parasitica var. nicotianae. $\mathrm{O}$ potencial de diversos isolados de $P$. parasitica para causar doença em fumo parece ter 
correlação direta com a capacidade do fungo em produzir e secretar elicitinas, sendo patogênicos os que não a produzem (Ricci et al., 1992).

Por sua vez, L. edodes, o cogumelo shiitake, apresenta compostos de origem polissacarídica e glicoprotéica, que modulam respostas imunológicas em animais, por ativação de macrófagos, podendo ainda apresentarem atividade antibiótica (Suzuki et al., 1979; Sugano et al., 1982; Mizuno, 1995). A partir do corpo de frutificação do cogumelo, Kobayashi et al. (1987) purificaram uma proteína que apresentou atividade inibitória à infecção do vírus do mosaico do fumo (Tobacco mosaic virus - TMV), a qual denominaram "proteína do corpo de frutificação" (PCF). A concentração de PCF para uma inibição de $50 \%$ da infectividade do TMV em fumo Nicotiana tabacum var. xanthi foi de 6,3 ppm, enquanto que 16,3 ppm inibiu 50\% da infectividade do ácido nucléico do TMV, sugerindo que a inibição não ocorreu no processo de desnudamento viral. A PCF também não mostrou atividade para hidrólise de RNA e o seu mecanismo de ação permanece não esclarecido (Hiramatsu et al., 1987). A atuação da PCF pode ter sido sobre a planta, ativando mecanismos de defesa, no entanto, não há relatos sobre a atividade elicitora da proteína em questão.

Em plantas de pepino mantidas sob condições de casa de vegetação, o extrato aquoso bruto, obtido a partir do corpo de frutificação de diferentes isolados do cogumelo, reduziu significativamente a antracnose provocada por Colletotrichum lagenarium, e aumentou a atividade de proteínas relacionadas à patogênese nas folhas, com destaque para peroxidases (Capítulo 3). Dessa forma, o objetivo do presente trabalho foi o de tentar obter moléculas de interesse agronômico a partir do corpo de frutificação de L. edodes, utilizando o patossistema plântulas de pepino x C. lagenarium, juntamente com a determinação da atividade de peroxidases nos cotilédones de pepino.

\subsection{Material e Métodos}

\subsubsection{Obtenção do extrato bruto de L. edodes}

Para a obtenção do extrato bruto, o pó seco de basidiocarpo recebeu água destilada (14 mL para cada grama), e após 24 h de incubação a $4{ }^{\circ} \mathrm{C}$, a suspensão passou 
por um filtro comum (gramatura: $8 \mathrm{~g} / \mathrm{cm}^{2}$ ) e foi centrifugada a $20.000 \mathrm{~g}$ por $25 \mathrm{~min}$, sendo o sobrenadante obtido considerado como o extrato bruto.

\subsubsection{Precipitação fracionada do extrato aquoso de basidiocarpos de L.edodes}

Utilizourse o isolado LE 96/22 de L. edodes. As proteínas presentes em $100 \mathrm{ml}$ de extrato bruto de basidiocarpos, obtidos do cultivo em Eucaliptus grandis e em E. saligna, foram precipitadas com sulfato de amônio em saturações de 0 a 20\%, 20 a 40\%, 40 a 60\%, 60 a $80 \%$ e 80 a 100\%. Para se evitar a desnaturação das mesmas, o sal foi dissolvido gradativamente, sob agitação, com a solução mantida a $10{ }^{\circ} \mathrm{C}$. Em cada etapa da precipitação fracionada, após o sal ter sido dissolvido, a solução permaneceu em repouso durante uma hora a $10{ }^{\circ} \mathrm{C}$ e foi centrifugada a $5.000 \mathrm{~g}$ por $35 \mathrm{~min}$. Posteriormente, as proteínas presentes em cada precipitado foram ressuspensas em $2 \mathrm{~mL}$ de água destilada. Após diálise contra água destilada $\left(4{ }^{\circ} \mathrm{C}, 48 \mathrm{~h}\right.$, três trocas), realizada em membrana com limite de exclusão equivalente a 6.000 - 8.000 Da, o volume de cada precipitado foi ajustado para $4 \mathrm{~mL}$ com água destilada. O conteúdo de proteínas das amostras foi quantificado pelo método de Bradford (1976), enquanto que, para a dosagem de açúcares redutores, foi utilizado o método de Lever (1972), o qual emprega a hidrazida do ácido $p$-hidroxibenzóico. As amostras foram utilizadas em bioensaio com plântulas de pepino para se verificar a proteção contra C. lagenarium.

\subsubsection{Bioensaio com plântulas de pepino}

Sementes de pepino (cultivar Caipira Verde) foram dispostas em bandejas de isopor contendo o substrato Plantimax, mantidas no interior de uma casa de vegetação. Quando apresentavam cotilédones com aproximadamente $3 \mathrm{~cm}$ de comprimento, as plântulas foram retiradas do substrato, lavadas, secas ao ar e imersas nos tratamentos durante $5 \mathrm{~s}$, de modo que apenas os cotilédones fossem atingidos (Labanca, 2002). As plântulas tratadas foram colocadas em tubos de ensaio $(9,0 \mathrm{~cm}$ altura $\mathrm{x} 1,4 \mathrm{~cm}$ diâmetro) contendo água destilada, e foram mantidas sob condições controladas (câmara de crescimento a $25{ }^{\circ} \mathrm{C}$ e com fotoperíodo de $12 \mathrm{~h}$ de luz/dia), até o final do experimento. Três dias após os tratamentos, os cotilédones foram inoculados com C. lagenarium $(1 \mathrm{x}$ 
$10^{5}$ esporos $/ \mathrm{mL}$ ), realizando-se aspersão (o isolamento e a obtenção de esporos do fitopatógeno estão descritos no capítulo 3). Foram realizadas quatro repetições por tratamento, sendo uma repetição constituída por quatro plântulas. Avaliou-se o bioensaio 5 dias após a inoculação, estimando-se a severidade da doença, em porcentagem.

Após a avaliação do bioensaio, a precipitação fracionada de proteínas foi efetuada a partir de uma amostra com $275 \mathrm{~mL}$ de extrato bruto de LE 96/22, utilizandose sulfato de amônio agora em saturações de 0 a 40\%, 40 a $80 \%$ e 80 a $100 \%$. Cada precipitado foi ressuspenso em $6 \mathrm{ml}$ de água destilada, dialisado e teve o volume final ajustado para $14 \mathrm{~mL}$ com água destilada. Seguiu-se, então, a realização de novo bioensaio com plântulas de pepino, como descrito acima.

\subsubsection{Separação do precipitado relativo à saturação de 40-80\% (p40-80) utilizando- se cromatografia}

Uma amostra de 4,5 $\mathrm{mL}$ do precipitado p40-80, o mais efetivo em reduzir a antracnose (Tabela 2), contendo $16 \mathrm{mg}$ de proteína, foi submetida à cromatografia de troca aniônica (CTA) em coluna $(2,5 \mathrm{~cm}$ de diâmetro interno $\mathrm{x} \quad 15,0 \mathrm{~cm}$ de comprimento) preenchida com DEAE-Celulose. A cromatografia foi efetuada com tampão Tris- $\mathrm{HCl} 10 \mathrm{mM}(\mathrm{pH} 8,0)$, em fluxo de $4 \mathrm{~mL} / \mathrm{min}$, e o material adsorvido à resina foi eluído de forma gradual "step wise", utilizando-se concentrações crescentes de $\mathrm{NaCl}$ no mesmo tampão (160 mL a 20 mM, $240 \mathrm{~mL}$ a 0,1 M e $160 \mathrm{~mL}$ a 1,0 M).

Uma outra amostra de $5 \mathrm{~mL}$ do precipitado p40-80 foi submetida à cromatografia de troca catiônica (CTC) em coluna $(2,5 \mathrm{~cm}$ de diâmetro interno $\mathrm{x} 10 \mathrm{~cm}$ de comprimento) preenchida com CM-Celulose. A cromatografia foi efetuada com tampão acetato $10 \mathrm{mM}(\mathrm{pH} \mathrm{5,0)}$, em fluxo de $3 \mathrm{~mL} / \mathrm{min}$, e o material adsorvido à resina foi eluído com $\mathrm{NaCl}(1 \mathrm{M})$, no mesmo tampão.

Após os resultados das cromatografias de troca aniônica e troca catiônica, descritas nos parágrafos anteriores, submeteu-se novamente o precipitado p40-80 à CTA. Dessa vez, a cromatografia foi realizada com tampão fosfato $25 \mathrm{mM}(\mathrm{pH} 6,0)$ e fluxo de 2,5 $\mathrm{mL} / \mathrm{min}$. $\mathrm{O}$ material adsorvido à resina foi eluído por gradiente linear de $\mathrm{NaCl}(0$ a $1 \mathrm{M})$ ou "step-wise". No último caso, utilizaram-se, em cada etapa, $150 \mathrm{~mL}$ 
do tampão fosfato contendo $\mathrm{NaCl}$ em concentrações crescentes (0, 200, 400, 600, 800 e $1.000 \mathrm{mM}$ ). As frações coletadas foram agrupadas de acordo com o perfil de proteínas, dialisadas contra água destilada, concentradas com polietileno glicol 20.000, e avaliadas em bioensaio com plântulas de pepino, depois de terem o volume final ajustado para 5 $\mathrm{mL}$ com água destilada.

Todo o material submetido à cromatografia foi filtrado (filtro com poros de 0,2 $\mu \mathrm{m}$ diâmetro) e desgaseificado por $10 \mathrm{~min}$.

\subsubsection{Determinação da atividade de peroxidases em cotilédones de pepino}

Plântulas de pepino, obtidas conforme o item 4.2.3, tiveram os seus cotilédones mergulhados nos materiais de interesse (picos protéicos oriundos da CTA). A seguir, as plântulas foram mantidas em tubos de ensaio contendo água destilada por 3 dias, sob condições controladas (câmara de crescimento, mantida a $25{ }^{\circ} \mathrm{C}$ e com fotoperíodo de 12 $\mathrm{h}$ de luz/dia), quando então os cotilédones foram coletados, com auxílio de uma tesoura. Foram realizadas quatro repetições por tratamento, sendo uma repetição constituída por 3 cotilédones.

As amostras foram maceradas na presença de nitrogênio líquido, homogeneizadas em 4,0 mL de tampão fosfato de sódio $100 \mathrm{mM}(\mathrm{pH}$ 6,0) (tampão de extração) e centrifugadas a $20.000 \mathrm{~g}$ por $30 \mathrm{~min}$, a $4{ }^{\circ} \mathrm{C}$. Os sobrenadantes foram utilizados para se avaliar a atividade de peroxidases, bem como o teor de proteínas totais.

A atividade de peroxidases nas amostras foi determinada espectrofotometricamente a $470 \mathrm{~nm}$ em uma mistura de reação que consistiu de $0,1 \mathrm{~mL}$ de extrato protéico e $2,9 \mathrm{~mL}$ de tampão de extração, este contendo guaiacol 0,25\% (v/v) e peróxido de hidrogênio $0,1 \mathrm{M}$. A reação foi conduzida a $30{ }^{\circ} \mathrm{C}$ durante $4 \mathrm{~min}$, com as medidas de densidade óptica tomadas a cada $20 \mathrm{~s}$, iniciando-se 1 min após a adição do extrato ao substrato. Após a quantificação de proteínas totais de cada amostra pelo método de Bradford (1976), os resultados foram expressos em unidades de Densidade Óptica a $470 \mathrm{~nm} / \mathrm{mg}$ proteína/ $\mathrm{min}$ (DO/mg prot/min). 


\subsubsection{Análise das frações biologicamente ativas através de eletroforese desnaturante} (SDS-PAGE)

O precipitado p40-80 e o pico $\mathrm{V}$, um dos picos protéicos obtidos após a separação de p40-80 em CTA, foram submetidos à eletroforese em gel de poliacrilamida (8 x $8 \mathrm{~cm}$ ) desnaturante descontínuo, utilizando o procedimento descrito por Laemmli (1970). O gel separador foi preparado na concentração de $10 \%$ de acrilamida, enquanto o concentrador na de $4 \%$. A eletroforese foi conduzida a $4{ }^{\circ} \mathrm{C}$, sob voltagem de $100 \mathrm{~V}$, durante $2 \mathrm{~h}$.

Em cada amostra (20 a $25 \mu \mathrm{L}$ ), foi adicionado volume idêntico de tampão desnaturante [62,5 mM fosfato de sódio $\mathrm{pH}$ 7,0; glicerol 10\% (v/v); SDS 2\% (m/v); azul de bromofenol $0,001 \%(\mathrm{~m} / \mathrm{v})]$. Antes da eletroforese, as amostras foram fervidas em banho-maria por 5 min e aplicadas no gel.

Após a eletroforese, o gel foi imerso em solução corante [azul de comassie R-250 $1 \%(\mathrm{~m} / \mathrm{v})$; etanol $40 \%(\mathrm{v} / \mathrm{v})$; ácido acético $10 \%(\mathrm{v} / \mathrm{v})]$, permanecendo sob agitação durante $50 \mathrm{~min}$. O gel foi então lavado com água destilada e imerso em solução descorante [etanol $40 \%(\mathrm{v} / \mathrm{v})$; ácido acético $10 \%(\mathrm{v} / \mathrm{v})$ ] durante $4 \mathrm{~h}$, sob agitação, realizando-se três trocas.

\subsection{Resultados}

4.3.1 Atividade protetora dos precipitados, obtidos a partir do extrato aquoso de basidiocarpos de L. edodes, em plântulas de pepino contra $C$. lagenarium

No primeiro fracionamento de proteínas do extrato bruto de L. edodes (isolado LE 96/22), todos os precipitados obtidos reduziram a severidade da antracnose em plântulas de pepino. No entanto, os precipitados englobando a faixa de 20 a $80 \%$ de saturação foram os mais efetivos (Tabela 1). 
Tabela 1. Efeito de precipitados obtidos a partir do extrato bruto de basidiocarpos de Lentinula edodes sobre a antracnose em plântulas de pepino. Volume utilizado de cada amostra $=4 \mathrm{~mL}$

\begin{tabular}{lcc}
\hline Tratamento & $\begin{array}{c}\text { Concentração de proteínas } \\
(\mu \mathrm{g} / \mathrm{mL})\end{array}$ & $\begin{array}{c}\text { Severidade da } \\
\text { antracnose }(\%)\end{array}$ \\
\hline Água & - & $39,3 \pm 2,9 \mathrm{a}$ \\
p0-20 & 70,1 & $23,0 \pm 6,1 \mathrm{~b}$ \\
p20-40 & 392,8 & $13,3 \pm 3,8 \mathrm{bc}$ \\
p40-60 & 2300,0 & $12,6 \pm 3,5 \mathrm{c}$ \\
p60-80 & 887,9 & $12,3 \pm 2,5 \mathrm{c}$ \\
p80-100 & 339,0 & $22,3 \pm 5,7 \mathrm{~b}$ \\
\hline
\end{tabular}

${ }^{1}$ Quantificação pelo método de Bradford (1976)

${ }^{2}$ Médias \pm desvio padrão seguidas por letras iguais não diferem significativamente a $5 \%$ pelo teste de Tukey

Considerando a eficiência relativa e a concentração de proteínas dos precipitados, realizou-se novo fracionamento das proteínas do extrato bruto de $L$. edodes com sulfato de amônio, agora em saturações de 0 a 40\%, 40 a $80 \%$ e 80 a 100\%. O tratamento de plântulas de pepino com esses materiais revelou que o melhor efeito protetor foi obtido com o precipitado p40-80 (Figura 1, Tabela 2), o qual foi subme tido à cromatografia. 
Tabela 2. Efeito de precipitados obtidos a partir do extrato bruto de basidiocarpos de Lentinula edodes sobre a antracnose em plântulas de pepino. Volume utilizado de cada amostra $=4 \mathrm{~mL}$

\begin{tabular}{lccc}
\hline Tratamento & Concentração de & Concentração de açúcares & Severidade da \\
\hline & proteínas $(\mu \mathrm{g} / \mathrm{mL})^{1}$ & redutores $(\mu \mathrm{g} / \mathrm{mL})^{2}$ & ${\text { antracnose }(\%)^{3}}^{3}$ \\
\hline Água & - & - & $52,0 \pm 6,4 \mathrm{a}$ \\
p0-40 & 1213,7 & 62,2 & $21,0 \pm 10,2 \mathrm{bc}$ \\
p40-80 & $\mathbf{3 6 2 8 , 4}$ & $\mathbf{1 4 1 , 3}$ & $\mathbf{6 , 0} \pm \mathbf{2 , 2} \quad$ c \\
p80-100 & 269,3 & 34,1 & $39,0 \pm 11,2 \mathrm{ab}$ \\
Sobrenadante & 1,9 & 20,2 & $50,0 \pm 2,2 \mathrm{a}$ \\
Extrato bruto & 346,3 & 6245,8 & $17,0 \pm 9,4 \quad \mathrm{c}$
\end{tabular}

${ }^{1}$ Quantificação pelo método de Bradford (1976)

${ }^{2}$ Quantificação pelo método de Lever (1972)

${ }^{3}$ Médias \pm desvio padrão seguidas por letras iguais não diferem significativamente a $5 \%$

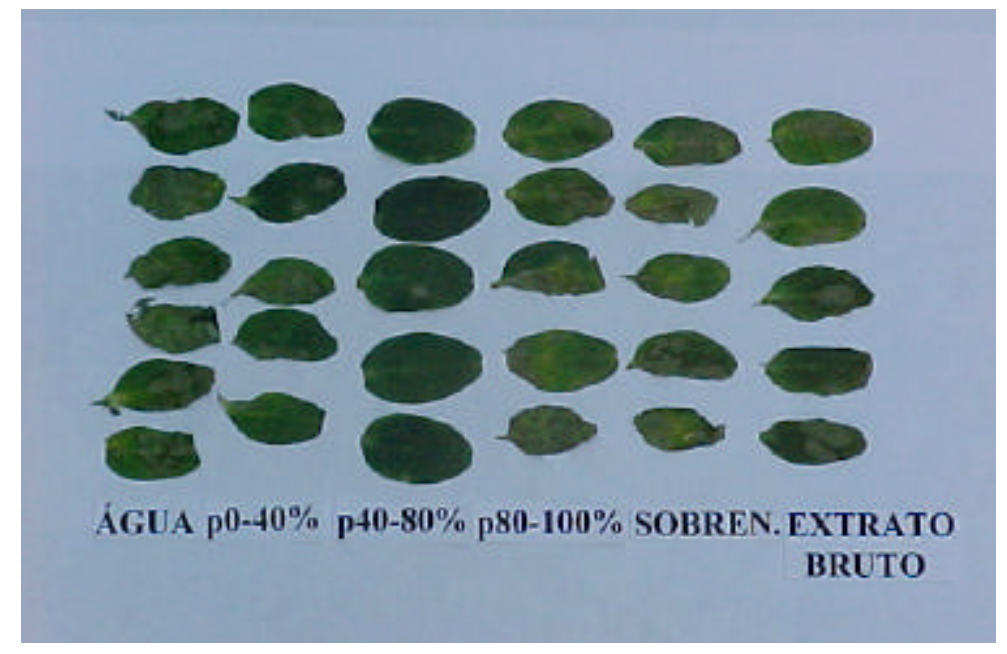

Figura 1 - Efeito de precipitados obtidos a partir do extrato bruto de basidiocarpos de Lentinula edodes sobre a antracnose em plântulas de pepino. Escala $1: 2,5$ 


\subsubsection{Separação das frações por cromatografias de troca iônica}

A cromatografia de troca iônica, nas condições iniciais, não foi eficiente para a separação do material com atividade biológica (o precipitado p40-80). A quase totalidade das proteínas presentes no precipitado ligaram-se à resina de DEAE-Celulose e, após a eluição com $\mathrm{NaCl}$, formaram um único pico, detectado a $280 \mathrm{~nm}$ (Figura 2). Por outro lado, não houve ligação das proteínas na resina de CM-Celulose durante a cromatografia de troca catiônica, evidenciado por um único pico no início da cromatografia (Figura 3).

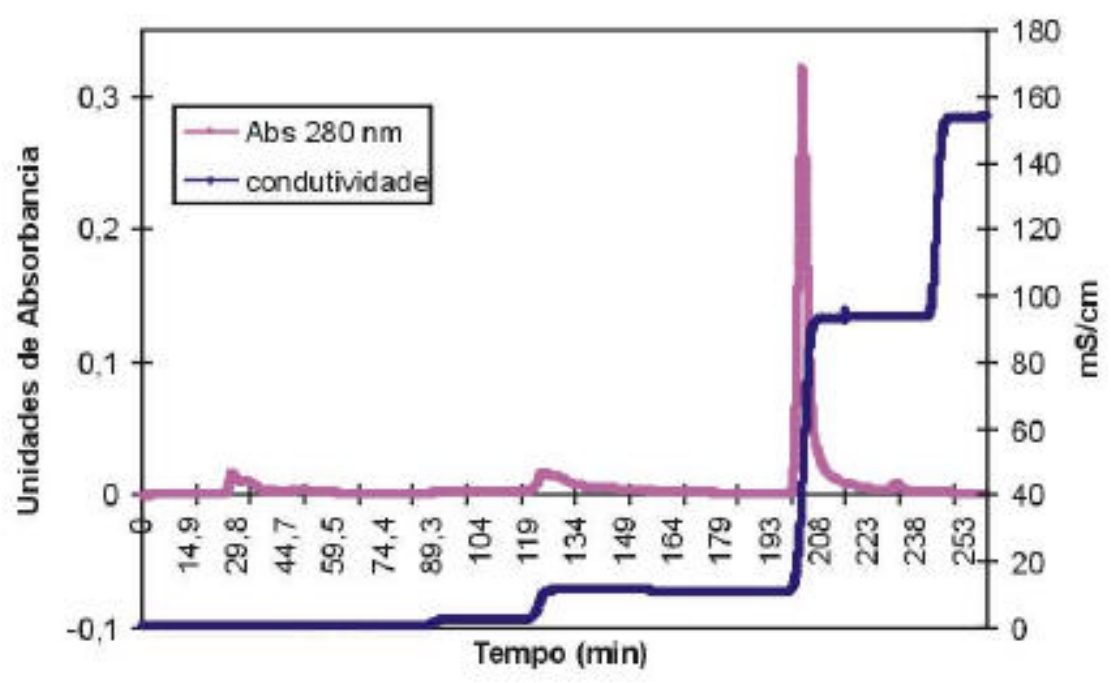

Figura 2 - Cromatografia de troca aniônica do precipitado p40-80, obtido a partir do extrato aquoso de basidiocarpos de Lentinula edodes. O material foi aplicado em coluna preenchida com DEAE-Celulose. A cromatografia foi efetuada com tampão Tris- $\mathrm{HCl} 10 \mathrm{mM}$ (pH 8,0), em fluxo de $4 \mathrm{~mL} / \mathrm{min}$, e o material adsorvido foi eluído com $\mathrm{NaCl}$ no mesmo tampão

Esses resultados mostraram que a maior parte das proteínas de interesse apresentam carga líquida negativa, por se ligarem a uma resina de troca aniônica (DEAE-Celulose) e não em uma de troca catiônica (CM-Celulose), o que não impede que contenham grupos carregados positivamente. 


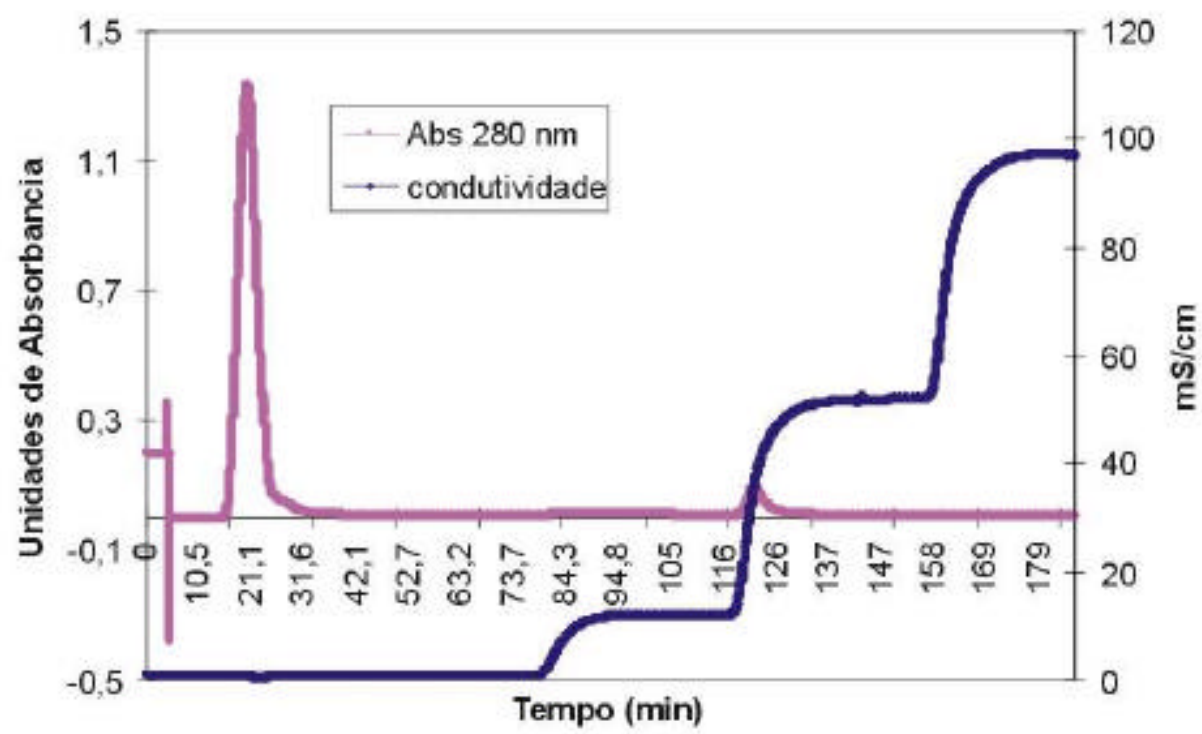

Figura 3 - Cromatografia de troca catiônica do precipitado p40-80, obtido a partir do extrato aquoso de basidiocarpos de Lentinula edodes. O material foi aplicado em coluna preenchida com CM-Celulose. A cromatografia foi efetuada com tampão acetato $10 \mathrm{mM}(\mathrm{pH} 5,0)$, em fluxo de $3 \mathrm{~mL} / \mathrm{min}$, e o material adsorvido foi eluído com $\mathrm{NaCl}$ no mesmo tampão

Para separar proteínas de carga negativa, o trocador indicado é o aniônico. $\mathrm{O}$ pH 8,0 utilizado inicialmente poderia estar contribuindo para uma ligação muito forte das proteínas à resina, dificultando a separação em picos distintos. Na nova tentativa de separar p40-80 em CTA, alterou-se o tampão para fosfato ( $\mathrm{pH} 6,0), \mathrm{pH}$ no qual as proteínas ainda apresentam carga líquida negativa (na CTC foi utilizado pH 5,0), mas não devem se ligar à resina de maneira tão estável. O resultado da cromatografia é ilustrado na Figura 4, onde ocorreu um avanço na separação de proteínas, embora não muito expressivo, indicando que a mudança de $\mathrm{pH}$ por si só não foi suficiente.

A próxima tentativa foi a de alterar o modo de eluição das proteínas ligadas à resina DEAE, adotando-se o procedimento "step wise", o mesmo adotado na primeira CTA, mas agora empregando maior número de etapas intermediárias, onde o tampão de eluição (fosfato) recebeu concentrações de $\mathrm{NaCl}$ crescentes em $0,2 \mathrm{M}$ a cada etapa. Com 
essa metodologia, foram obtidos seis picos quando uma amostra contendo $10 \mathrm{mg}$ de proteína do precipitado p40-80 foi submetida à CTA, conforme ilustra a Figura 5. Esses picos foram testados no bioensaio, mas nenhum propiciou controle da antracnose (dados não mostrados).

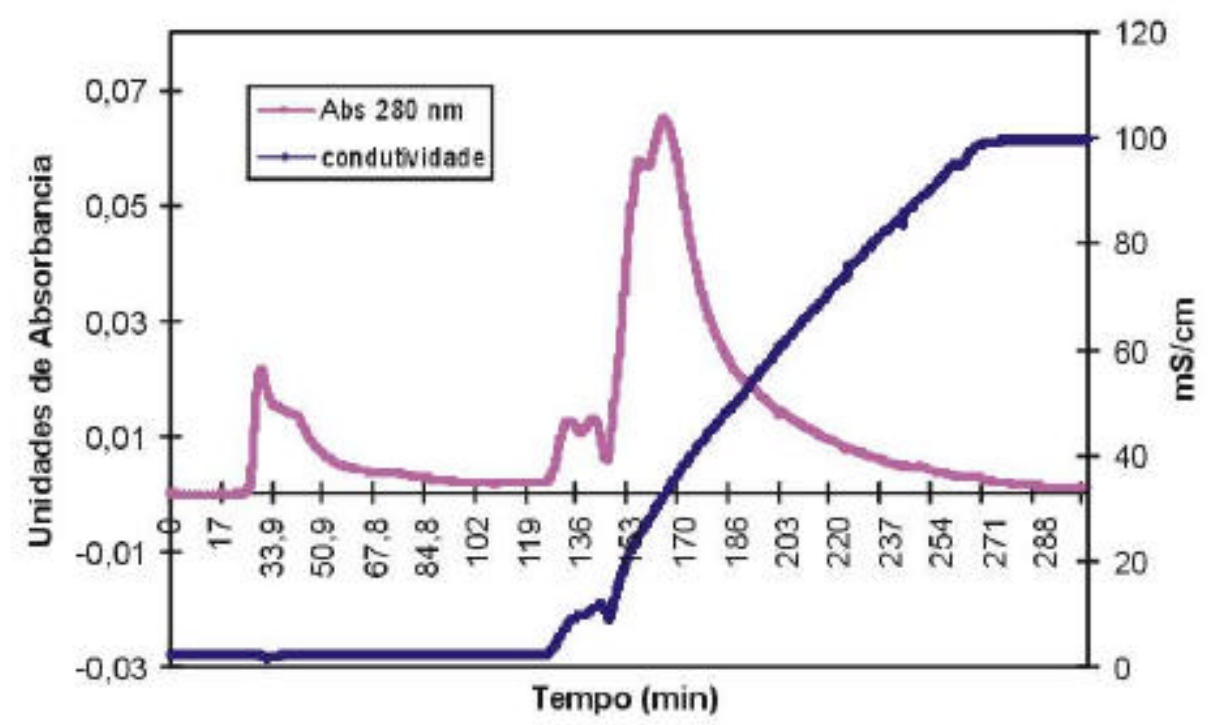

Figura 4 - Cromatografia de troca aniônica do precipitado p40-80, obtido a partir do extrato aquoso de basidiocarpos de Lentinula edodes. O material foi aplicado em coluna preenchida com DEAE-Celulose. A cromatografia foi efetuada com tampão fosfato $25 \mathrm{mM}$ (pH 6,0), em fluxo de $2,5 \mathrm{~mL} / \mathrm{min}$, e o material adsorvido foi eluído com um gradiente linear de $\mathrm{NaCl}(0$ a $1 \mathrm{M})$ no mesmo tampão

Submeteu-se, novamente, o precipitado p40-80 à CTA, efetuada com tampão fosfato $25 \mathrm{mM}(\mathrm{pH} \mathrm{6,0),} \mathrm{mas} \mathrm{aplicando-se} \mathrm{agora} 24 \mathrm{mg}$ de proteíma à coluna. Após o procedimento "step wise", foram obtidos os mesmos seis picos da cromatografia anterior, mas ocorrendo uma concentração um pouco maior de proteínas por pico (Figura 6). Quando aplicados nas plântulas de pepino, o pico V apresentou controle significativo da antracnose no primeiro bioensaio (Tabela 3). Em um segundo bioensaio, 
realizado com os picos protéicos obtidos a partir de um novo lote de basidiocarpos de LE 96/22, ajustados para que apresentassem a mesma concentração protéica do primeiro bioensaio, nenhum dos picos foi efetivo para reduzir a severidade da antracnose, enquanto o precipitado p40-80 propiciou controle da doença em aproximadamente 50\% (dados não mostrados).

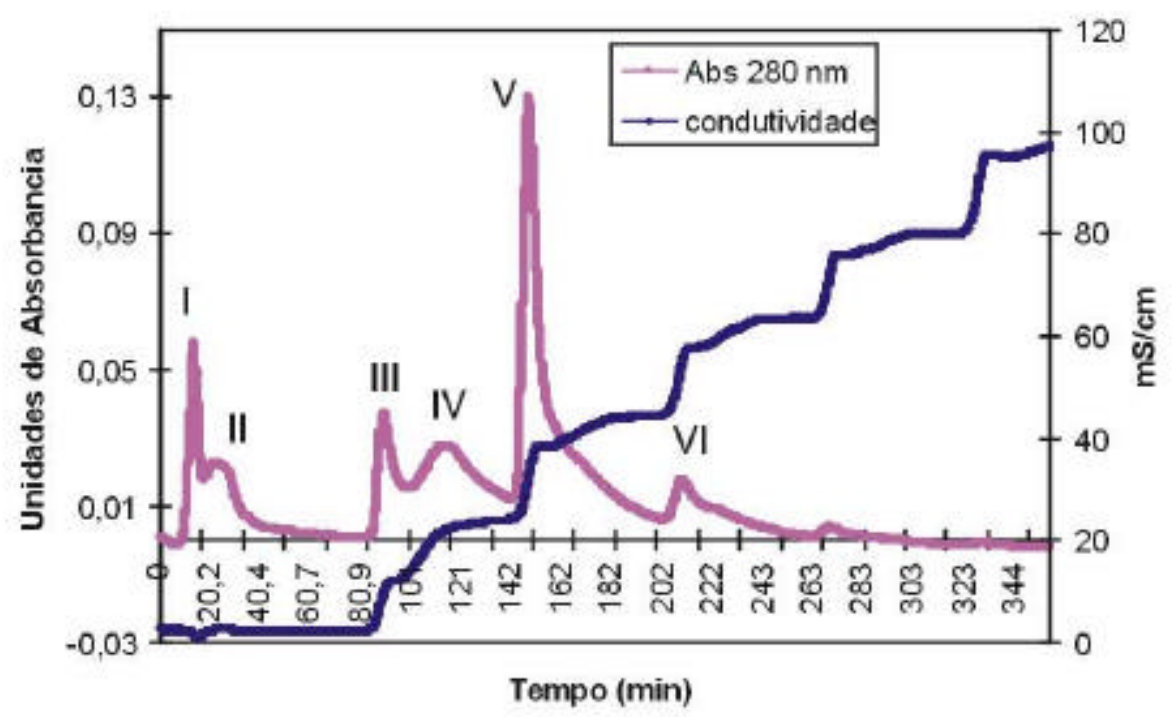

Figura 5 - Cromatografia de troca aniônica do precipitado p40-80, obtido a partir do extrato aquoso de basidiocarpos de Lentinula edodes. $\mathrm{O}$ material, contendo $10 \mathrm{mg}$ de proteína, foi aplicado em coluna preenchida com DEAE-Celulose. A cromatografia foi efetuada com tampão fosfato $25 \mathrm{mM}(\mathrm{pH} 6,0)$, em fluxo de $2,5 \mathrm{~mL} / \mathrm{min}$, e o material adsorvido foi eluído com $\mathrm{NaCl}$ no mesmo tampão, em procedimento "step wise" 


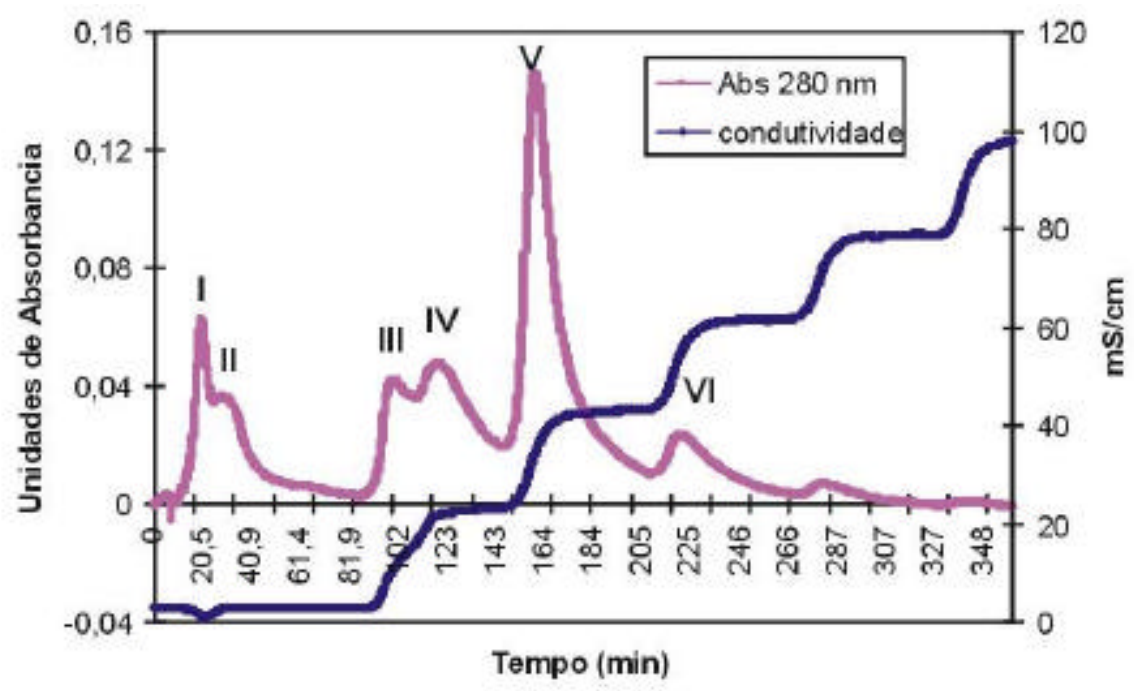

Figura 6 - Cromatografia de troca aniônica do precipitado p40-80, obtido a partir do extrato aquoso de basidiocarpos de Lentinula edodes. $\mathrm{O}$ material, contendo $24 \mathrm{mg}$ de proteína, foi aplicado em coluna preenchida com DEAE-Celulose. A cromatografia foi efetuada com tampão fosfato $25 \mathrm{mM}(\mathrm{pH} 6,0)$, em fluxo de $2,5 \mathrm{~mL} / \mathrm{min}$, e o material adsorvido foi eluído com $\mathrm{NaCl}$ no mesmo tampão, em procedimento "step wise"

Tabela 3. Efeito de frações proteicas agrupadas (picos), obtidas a partir da separação do precipitado p40-80 de Lentinula edodes em cromatografia de troca aniônica (Figura 6), sobre a antracnose em plântulas de pepino

\begin{tabular}{lcc}
\hline Tratamento & $\begin{array}{c}\text { Quantidade de } \\
\text { proteínas em } 5 \mathrm{~mL}\end{array}$ & $\begin{array}{c}\text { Severidade da } \\
\text { antracnose (\%) }\end{array}$ \\
\hline Água & - & $26,0 \pm 12,0$ \\
Pico I & $1,18 \mathrm{mg}$ & $13,0 \pm 4,0$ \\
Pico II & $0,30 \mathrm{mg}$ & $16,0 \pm 5,0$ \\
Pico III & $1,25 \mathrm{mg}$ & $17,0 \pm 6,0$ \\
Pico IV & $1,74 \mathrm{mg}$ & $10,0 \pm 3,0$ \\
Pico V & $8,20 \mathrm{mg}$ & $8,5 \pm 1,2^{*}$ \\
Pico VI & $0,72 \mathrm{mg}$ & $18,0 \pm 7,0$
\end{tabular}

*Significativo a 5\% pelo teste de Dunnett (referência = cotilédones tratados com água) 


\subsubsection{Determinação da atividade de peroxidases em cotilédones de pepino}

Os picos III e V, assim como o precipitado p40-80 (Tabela 3, Figura 6) elevaram a atividade de peroxidases em cotilédones de pepino em relação aos tratados com água destilada (Tabela 4). O experimento foi repetido e mostrou as mesmas tendências.

Tabela 4. Atividade de peroxidases em cotilédones de pepino tratados com as preparações presentes nos picos protéicos provenientes da separação de p4080 em cromatografia de troca aniônica

\begin{tabular}{lcc}
\hline Tratamento & $\begin{array}{c}\text { Quantidade de } \\
\text { proteínas em } 5 \mathrm{~mL}\end{array}$ & $\begin{array}{c}\text { Atividade de peroxidases } \\
(\mathrm{DO} / \mathrm{mg} \mathrm{prot} / \mathrm{min})\end{array}$ \\
\hline Água & - & $10,1 \pm 1,8$ \\
Pico III & $1,5 \mathrm{mg}$ & $15,4 \pm 1,5^{*}$ \\
Pico IV & $2,0 \mathrm{mg}$ & $12,9 \pm 3,7$ \\
Pico V & $8,0 \mathrm{mg}$ & $15,7 \pm 3,1^{*}$ \\
Pico VI & $0,7 \mathrm{mg}$ & $10,7 \pm 1,4$ \\
p40-80** & $8,0 \mathrm{mg}$ & $15,9+3,5^{*}$
\end{tabular}

*Significativo a 5\% pelo teste de Dunnett (referência = cotilédones tratados com água)

**Precipitado obtido a partir do extrato aquoso de basidiocarpo de L. edodes, correspondente a uma saturação com sulfato de amônio de 40 a $80 \%$

\subsubsection{Análise das frações biologicamente ativas através de eletroforese desnaturante} (SDS-PAGE)

Após a eletroforese, foi possível identificar pelo menos seis bandas no precipitado p40-80, enquanto somente duas foram visíveis a partir da amostra relativa ao pico V. As proteínas (ou glicoproteínas) do pico V apresentam massa molecular aproximadamente de 29 e $35 \mathrm{kDa}$ (Figura 7). 


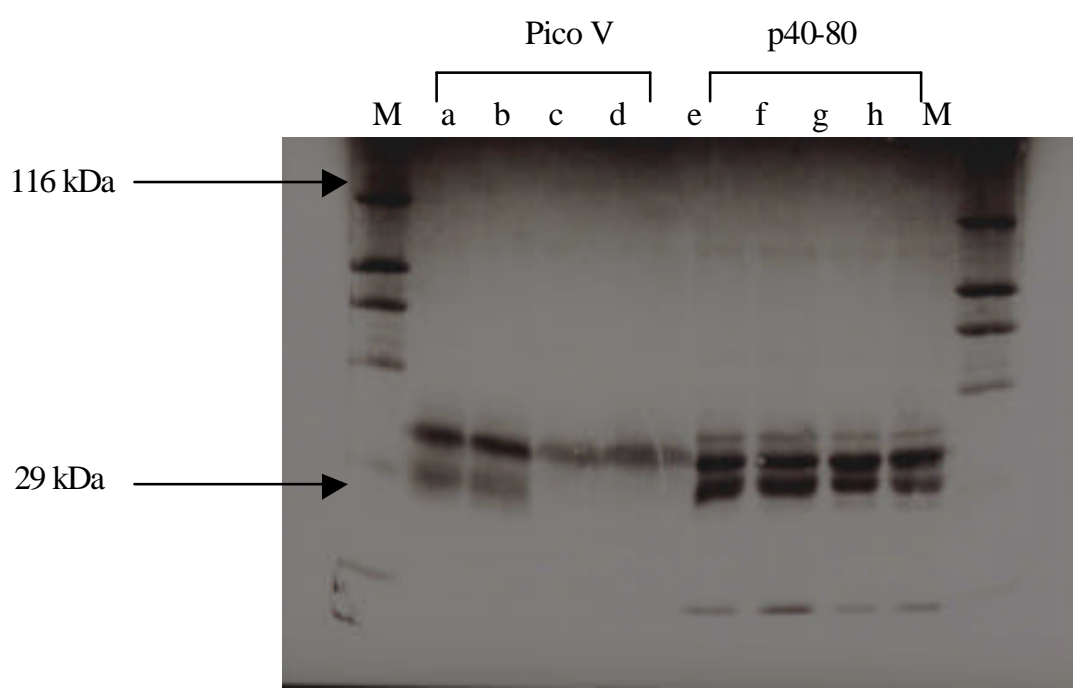

Figura 7 - Separação eletroforética em gel de poliacrilamida das proteínas do pico $\mathrm{V}$ e do precipitado p40-80, provenientes do isolado LE 96/22 de Lentinula edodes, obtidos a partir de dois lotes diferentes de basidiocarpos. Lote 1 - a, b, e, f; lote $\underline{2}$ - c, d, g, h. Quantidade de proteína aplicada: $28 \mu \mathrm{g}$ em (a) e (c), $35 \mu \mathrm{g}$ em (b) e (d), $50 \mu \mathrm{g}$ em (e) e (g), $70 \mu \mathrm{g} \mathrm{em} \mathrm{(f)} \mathrm{e} \mathrm{(h).} \mathrm{M} \mathrm{=} \mathrm{marcador} \mathrm{molecular}$

\subsection{Discussão}

L. edodes, o cogumelo shiitake, protege plantas de pepino contra C. lagenarium, sob condições de casa de vegetação, na dependência da concentração do extrato aquoso de basidiocarpo utilizada. Além disso, o extrato bruto a $20 \%(\mathrm{v} / \mathrm{v})$, desencadeou o acúmulo de peroxidases nas folhas de pepino tratadas, bem como sistemicamente (Capítulo 3).

Muitos autores consideram o acúmulo de peroxidases como um marcador bioquímico da resistência induzida em pepineiro (Dean \& Kuc, 1987; Conti et al., 1994), embora a correlação entre a atividade dessas enzimas e a proteção das plantas nem sempre é evidente (Schneider \& Ullrich, 1994). 
$\mathrm{Na}$ presente investigação, obteve-se uma purificação parcial de elicitores de peroxidases em plântulas de pepino a partir do extrato de basidiocarpos de L. edodes, utilizando-se precipitação fracionada de moléculas com sulfato de amônio e cromatografia de troca aniônica. Nesta, o emprego de tampão fosfato ( $\mathrm{pH}$ 6,0), com o procedimento "step wise", foi o mais eficiente para a eluição das proteínas ligadas à resina.

O material que propiciou alguma atividade protetora e desencadeou o acúmulo de peroxidases em cotilédones de pepino estava presente no pico V (Tabelas 3 e 4). Esse pico foi separado em mais de uma banda em gel de poliacrilamida desnaturante e, em função da metodologia adotada para a sua obtenção, apresenta predominantemente proteínas em sua constituição. O pico III também elicitou o acúmulo de peroxidases nos cotilédones, mas não os protegeu contra $C$. lagenarium em dois bioensaios independentes.

Outros elicitores protéicos e glicoprotéicos têm sido obtidos a partir de microrganismos, alguns desses tendo sido mostrados induzir resistência em plantas contra patógenos de interesse agronômico. É o caso da glicoproteína purificada a partir do micélio de Pyricularia oryzae, agente causal da brusone em arroz. $\mathrm{O}$ tratamento de folhas de arroz com esse elicitor provocou uma elevação nas atividades de peroxidases, cinamil-álcool desidrogenase e lipoxigenase. Além disso, a infiltração do elicitor bruto junto aos espaços intercelulares de folhas de arroz resultou em aumento da autofluorescência das células epidermais e do mesófilo, apontando para o acúmulo de lignina ou de material semelhante à lignina nos tecidos tratados. O elicitor de P. oryzae reduziu os sintomas da brusone nas folhas tratadas em comparação com as que foram infiltradas com água (Schaffrath et al., 1995). Elicitores protéicos conhecidos como elicitinas, isolados a partir de Phytophthora spp., ambém mostraram capacidade para induzir resistência em plantas de fumo contra P. parasitica var. nicotianae (Ricci et al., 1992).

O emprego comercial de um elicitor protéico iniciou-se com a descoberta da harpina, proteína com $44 \mathrm{kDa}$, rica em glicina e estável ao calor. A harpina é sintetizada por algumas bactérias fitopatogênicas, como Erwinia amylovora e Pseudomonas 
syringae, sendo requerida para a patogenicidade nas respectivas espécies hospedeiras, e capaz de elicitar uma reação de hipersensibilidade $(\mathrm{RH})$ em espécies não hospedeiras, quando infiltrada junto aos espaços intercelulares do tecido foliar (Wei et al., 1992; Adam et al., 1997). A harpina tem a capacidade de induzir resistência em plantas nãohospedeiras da mesma forma que a bactéria que a sintetiza (Jin et al., 1997).

A pulverização foliar de harpina não provoca $\mathrm{RH}$ visível, mas ativa outras respostas de defesa vegetal, induzindo resistência sistêmica. O efeito da proteína já foi demonstrado em Arabidopsis thaliana contra Peronospora parasítica e P.syringae pv. tomato (Dong et al., 1999), em plantas de pepino contra Gliocladium sp., em tomateiro contra Ralstonia solanacearum (Wei et al., 1996), em pimentão contra o Beet curly top vírus (Jones, 2001), entre outros. Além de controlar doenças, a proteína promove o crescimento vegetal por estimular a atividade fotossintética e o acúmulo de nutrientes pelas plantas (Bednarz et al., 2002). Baseado nesses achados, harpina foi desenvolvida pela empresa EDEN Bioscience dando origem ao produto comercial Messenger ${ }^{\circledR}$, o qual apresenta 3\% da proteína elicitora (o ingrediente ativo) em sua composição. No caso de elicitores não-protéicos, já foram desenvolvidos alguns produtos comerciais como o Agromos $^{\circledR}$, baseado em mananoligossacarídeos fosforilados derivados da parede celular de $S$. cerevisiae, e Elexa ${ }^{\circledR}$, que apresenta quitosana como o princípio ativo.

Quanto a L. edodes, o pico V contém em média $25 \%$ das proteínas presentes no precipitado p40-80 e aproximadamente $15 \%$ das presentes no extrato aquoso bruto do basidiocarpo. O efeito protetor desse pico foi inferior ao do precipitado p40-80, indicando que houve perda de componente(s) ativo(s) do cogumelo durante o procedimento de purificação. Por outro lado, a atividade de peroxidases em cotilédones de pepino foi semelhante para plântulas tratadas com o pico V ou com p40-80, revelando um avanço na purificação de elicitores presentes no basidiocarpo de L. edodes. Novos estudos envolvendo a aplicação das frações de interesse em plantas poderão mostrar a viabilidade de se obter um produto comercial a partir do cogumelo shiitake. 


\subsection{Conclusões}

A precipitação fracionada de moléculas com sulfato de amônio seguida por cromatografia de troca aniônica das frações de interesse permitiram a purificação parcial de elicitores de peroxidases em cotilédones de pepino, obtidos a partir do extrato aquoso de basidiocarpos de L. edodes (cogumelo shiitake). 


\section{EFEITO DOS COGUMELOS Lentinula edodes E Agaricus blazei NA PROTEÇÃo de PLANTAS DE MARACUJÁ CONTRA O Passion fruit woodiness virus (PWV)}

\section{Resumo}

O endurecimento dos frutos do maracujazeiro, causado pelo Passion fruit woodiness virus (PWV), é um dos problemas mais sérios que atingem a cultura. Tentativas de se obter plantas tolerantes ao vírus ou estirpes fracas premunizantes não apresentaram sucesso até o momento. O objetivo do presente estudo foi o de avaliar a proteção das plantas de maracujá contra o PWV, utilizando preparações dos cogumelos Lentinula edodes e Agaricus blazei, através da indução de resistência. $\mathrm{O}$ cogumelo $L$. edodes, pesquisado há mais tempo, mostrou possuir inibidores de vírus que infectam animais ou vegetais, além de substâncias estimuladoras do sistema imunológico animal e potencialmente ativadoras dos mecanismos de defesa vegetal. Em experimentos conduzidos no interior de casa de vegetação e em telado coberto com sombrite, os extratos de basidiocarpos de ambos os cogumelos, dependendo da concentração utilizada, reduziram significativamente a incidência da virose em plantas de maracujá que tiveram as folhas pré-tratadas com esses extratos e posteriormente inoculadas mecanicamente com o PWV (proteção local). Não houve, no entanto, controle da virose nos testes de proteção sistêmica. O efeito inibidor dos extratos, atuando diretamente sobre o vírus, foi confirmado inoculando-se Chenopodium quinoa com uma mistura de extratos e suspensão viral. Ainda em $C$. quinoa, um hospedeiro de lesão local do PWV, os extratos de alguns isolados dos cogumelos induziram resistência sistêmica contra o vírus, o que foi verificado através da redução do número de lesões locais em folhas não tratadas de plantas que receberam os extratos. Os resultados mostram que os extratos 
aquosos de basidiocarpos de L. edodes e A. blazei podem ativar mecanismos de defesa vegetal contra o PWV, mas não em magnitude suficiente para proteger uma espécie de interesse econômico que é invadida sistemicamente pelo vírus.

\section{Summary}

The Passion fruit woodiness virus (PWV) is one of the most serious problems in passion fruit culture. Attempts to obtain tolerant plants to the virus or PWV weak strains for cross-protection did not show success up to now. The objective of the present study was to evaluate the protection of passion fruit plants against PWV, by using preparations from Lentinula edodes and Agaricus blazei mushrooms. The mushroom L. edodes showed to possess virus inhibitors that infect animals or plants, besides substances that stimulate animal immune system and with potential to activate plant defense mechanisms. In experiments carried out in greenhouse or under shade conditions, the fruiting body extracts from both mushrooms, depending upon the concentration, reduced significantly the virus incidence on passion fruit plants. This protecting effect occurred when plant leaves were treated with extracts and later inoculated mechanically with PWV (local protection), but systemic protection was not verified. The inhibitor effect of mushroom extracts, acting directly on to the virus particles, was confirmed on Chenopodium quinoa plants inoculated with a mixture of extracts and virus suspension. In $C$. quinoa, a PWV local lesion host, the mushroom extracts from some isolates also induced systemic resistance against the virus, what was verified through the reduction of the local lesion number in non-treated leaves from plants that received the extracts. The results show that the aqueous extracts from L. edodes and A. blazei fruiting bodies can activate plant defense mechanisms against PWV, but not in a magnitude able to protect an economical interest species that is systemically invaded by the virus.

\subsection{Introdução}

A doença provocada pelo vírus do endurecimento dos frutos (Passion fruit woodiness virus - PWV) é uma das mais importantes da cultura do maracujazeiro amarelo (Passiflora edulis f. flavicarpa Deg.), afetando seriamente a longevidade e a 
produtividade das plantas. Os danos são maiores à medida que as plantas se tornam infectadas precocemente durante a estação de crescimento (Rezende, 1994; Gioria et al., 2000). Os sintomas envolvem a deformação e o mosaico foliares, a redução no crescimento das plantas, o endurecimento e deformação dos frutos.

No Brasil, há relatos de ocorrência do PWV em espécies cultivadas ou silvestres de Passiflora e em Phaseolus vulgaris (Inoue et al., 1995). O vírus é capaz de infectar sistemicamente outras culturas, como amendoim, centrosema, crotalaria, soja, fumo (Taylor \& Greber, 1973; Chang, 1992). Em Chenopodium quinoa, o PWV causa apenas lesões locais nas folhas inoculadas (Rezende, 1994).

Em áreas com abundância de hospedeiros alternativos do vírus e com alta população de afídeos vetores, destacando-se o Myzus persicae e o Aphis gossypii, o controle da doença é muito difícil. Não há disponibilidade de materiais geneticamente resistentes ou tolerantes ao vírus e o controle químico dos vetores é ineficiente para reduzir o problema com a virose, dado que a transmissão do PWV é realizada de maneira não-persistente, por meio da picada de prova dos pulgões.

Tratando-se de uma cultura semi-perene, podendo permanecer no campo alguns anos, a premunização da mesma, utilizando estirpes fracas do vírus, poderia contribuir para a redução dos danos provocados pelas estirpes fortes do PWV. No entanto, até o momento, a medida não se mostrou eficaz, devido a uma quebra de proteção provavelmente relacionada à baixa concentração e à distribuição irregular das estirpes fracas nas folhas do maracujazeiro (Novaes, 2002).

Nesse sentido, outras medidas devem ser pesquisadas na tentativa de diminuir o impacto da virose. Entre essas, a indução de resistência merece consideração. Além dos menores riscos associados ao impacto ambiental, uma série de relatos mostram a possibilidade de se controlar doenças provocadas por vírus através da resistência induzida.

Proteínas vegetais isoladas a partir de Clerodendrum aculeatum induziram resistência sistêmica em Nicotiana tabacum contra o Tobacco mosaic virus (TMV) (Verma et al., 1996), enquanto as purificadas a partir de Clerodendrum inerme (Crip-31) protegeram sistemicamente N. tabacum contra os vírus Cucumber mosaic virus (CMV), 
Potato virus Y(PVY) e o Tomato mosaic virus (ToMV) (Praveen et al., 2001). O efeito foi atribuído ao acúmulo local e sistêmico de proteínas antivirais, sintetizadas pelos hospedeiros após o tratamento com as proteínas vegetais purificadas. $\mathrm{O}$ aspecto mais interessante de Crip-31 é a sua efetividade em N. tabacum, hospedeiro sistêmico dos vírus considerados, já que a maioria das proteínas antivirais mostram-se efetivas somente em hospedeiros de lesão local.

Microrganismos também atuam como indutores de resistência contra viroses. Filtrados de cultura do fungo Stachybotrys chartarum, aplicados sobre hospedeiros sistêmicos, diminuíram o desenvolvimento de sintomas de diferentes vírus. Um intervalo de 3 a 5 dias entre a aplicação do filtrado e a inoculação viral foi suficiente para induzir resistência (Maiss, 1987). Suspensões de uredosporos de Uromyces phaseoli, agente causal da ferrugem, bem como o fluido de lavagem intercelular obtido a partir de plantas infectadas com ferrugem, induziram resistência sistêmica em feijoeiro contra o Tobacco necrosis virus (TVN) (Kutzner et al., 1993). O tratamento de sementes de pepino com as rizobactérias promotoras de crescimento, Pseudomonas fluorescens e Serratia marcescens, reduziu significativamente e consistentemente a incidência do CMV em plântulas inoculadas mecanicamente nos cotilédones, aos 10 dias após o plantio (Raupach et al., 1996).

L. edodes, o cogumelo shiitake, e A. blazei, o cogumelo-do-sol, contêm substâncias antivirais, o que tem provocado o aumento de pesquisas envolvendo esses basidiomicetos. Lentinana, uma glucana isolada do basidiocarpo de shiitake, inibe a replicação de HIV in vitro, assim como a de outros vírus que infectam animais (Tochikura et al., 1988), além de inibir a infectividade do TMV (Piccinin, 2000). Uma proteína purificada a partir do basidiocarpo de L. edodes (PCF) foi altamente efetiva contra o TMV, reduzindo em 50\% a infectividade desse vírus em Nicotiana tabacum var. xanthi, quando utilizada em uma concentração de 6,3 ppm (Hiramatsu et al., 1987).

Algumas das substâncias produzidas por L. edodes e A. blazei, incluindo lentinana e outras glucanas, são ativadoras do sistema imunológico animal, auxiliando o hospedeiro no combate a infecções. Entretanto, existem poucos relatos sobre a capacidade dessas substâncias em ativar o sistema de defesa vegetal. Dessa forma, o 
objetivo desse trabalho foi o de se avaliar a proteção de plantas de maracujá contra o PWV, utilizando-se extratos de basidiocarpos e filtrados do cultivo micelial dos cogumelos.

\subsection{Material e Métodos}

\subsubsection{Obtenção dos preparados de L. edodes (shiitake) e de A. blazei (cogumelo-do- sol)}

Para a obtenção do extrato aquoso de cada isolado, o pó seco de basidiocarpo recebeu água destilada (14 $\mathrm{mL}$ para cada grama), e após $24 \mathrm{~h}$ de incubação a $4{ }^{\circ} \mathrm{C}$, a suspensão foi filtrada em filtro comum (gramatura: $8 \mathrm{~g} / \mathrm{cm}^{2}$ ) e centrifugada a $20.000 \mathrm{~g}$ por $25 \mathrm{~min}$, sendo o sobrenadante novamente filtrado, agora em membrana do tipo Millipore (diâmetro do poro $=0,2 \mu \mathrm{m}$ ), sob condições assépticas. Os filtrados esterilizados (extratos aquosos concentrados) foram armazenados em geladeira a $4{ }^{\circ} \mathrm{C}$ e utilizados, após diluições, na maioria dos testes de proteção de plantas. Extrato aquoso a $10 \% \mathrm{v} / \mathrm{v}(10 \mathrm{~mL}$ de extrato concentrado $+90 \mathrm{~mL}$ de água destilada) contém o equivalente a 7,15 mg pó seco de basidiocarpo/ $\mathrm{mL}$. Quando não especificado nas tabelas e figuras, os isolados de L. edodes utilizados representam uma mistura de basidiocarpos produzidos em Eucaliptus grandis e em E. saligna. Os basidiocarpos dos isolados de A. blazei são provenientes de cultivo axênico.

Outro tipo de preparação, que foi utilizada em alguns testes, foi o "filtrado de crescimento micelial" de shiitake. Para tal, nove discos $(0,5 \mathrm{~cm}$ de diâmetro) retirados de BDA contendo crescimento vegetativo de $L$. edodes foram repicados para erlenmeyers com $150 \mathrm{~mL}$ de meio líquido BD (batata-dextrose). Após 5 meses de cultivo, a $24 \pm 2$ ${ }^{\circ} \mathrm{C}$, sob agitação, o conteúdo dos erlenmeyers foi filtrado em papel de filtro Whatmann número 40, obtendo-se o "filtrado do crescimento micelial" (FCM).

\subsubsection{Planta e patógeno}

O material vegetal utilizado nos experimentos constituiu-se de plantas de maracujá amarelo conhecido como Sul-Brasil. As sementes foram dispostas em bandejas contendo substrato e, quando as plântulas apresentavam 6 a $8 \mathrm{~cm}$ de altura, foram 
transplantadas para vasos de alumínio de 2 litros preenchidos com terra e esterco curtido, na proporção de 3:1.

Um isolado do PWV, obtido a partir de plantas de maracujá cultivadas em Vera Cruz/SP e infectadas com o vírus, foi cedido pelo Prof. Dr. Jorge A. M. Rezende (Setor de Fitopatologia - ESALQ/USP). O isolado foi mantido em plantas de maracujá cultivadas em uma casa de vegetação, através de inoculações mecânicas mensais.

\subsubsection{Proteção de plantas de maracujá inoculadas mecanicamente com o PWV}

Para a verificação da proteção local em maracujá, os extratos aquosos de $L$. edodes ou de A. blazei (15 mL de extrato por planta) foram aspergidos na planta toda (plantas com seis a oito folhas) e, após um intervalo de tempo, inocularam-se as plantas mecanicamente em uma ou duas folhas da porção média com o PWV proveniente de uma planta sistemicamente infectada, mantida como fonte de inóculo em casa de vegetação. Para testar o efeito sistêmico dos cogumelos, a planta toda foi tratada, com exceção de uma ou duas folhas da porção média da planta, as quais foram inoculadas com o vírus mecanicamente, após um determinado intervalo de tempo.

Nos experimentos de inoculação mecânica, o inóculo viral consistiu de $1 \mathrm{~g}$ de folhas com sintomas, o qual foi macerado em $40 \mathrm{~mL}$ de tampão fosfato $0,2 \mathrm{M}(\mathrm{pH} 7,0)$. A avaliação da proteção foi realizada pela observação visual de plantas com sintomas típicos da virose (mosaico, deformação foliar, bolhas foliares) e pela determinação da incidência da doença em cada tratamento aos 30 dias após a inoculação.

\subsubsection{Realização do teste serológico DAS-ELISA indireto}

Para a realização do teste serológico "Indirect Double Antibody Sandwich Enzyme Linked Immunosorbent Assay" (DAS-ELISA indireto), foram utilizadas Imunoglobulinas G (IgG) e Y (IgY), produzidas em coelho e galinha, respectivamente, e que reconhecem o PWV. Inicialmente foram adicionados $100 \mu \mathrm{L}$ de solução de $\mathrm{IgG}$, na concentração de $10 \mu \mathrm{g} / \mathrm{mL}$, diluída em tampão carbonato $\left(0,015 \mathrm{M} \mathrm{Na}_{2} \mathrm{CO}_{3}, 0,035 \mathrm{M}\right.$ $\mathrm{NaHCO}_{3}, \mathrm{pH}=9,6$ ) em cada pocinho de uma placa de ELISA. Após duas horas de incubação a $37{ }^{\circ} \mathrm{C}$, a placa foi lavada com tampão PBS-Tween $\left(0,0015 \mathrm{M} \mathrm{KH}_{2} \mathrm{PO}_{4}, 0,14\right.$ 
$\mathrm{M} \mathrm{NaCl}, 0,004 \mathrm{M} \mathrm{Na}_{2} \mathrm{HPO}_{4}, 0,003 \mathrm{M} \mathrm{KCl}, \mathrm{pH}$ 7,4 + 0,5 mL Tween 20/L) por 3 vezes. Em seguida, cada pocinho recebeu $100 \mu \mathrm{L}$ de extrato foliar proveniente de uma planta de maracujá (cada amostra foi representada por uma folha nova da planta, macerada em $2 \mathrm{~mL}$ de tampão PBS-Tween). A placa de ELISA contendo os extratos foliares foi incubada por $12 \mathrm{~h}$ a $10{ }^{\circ} \mathrm{C}$. Após lavagem da placa com PBS-Tween por 3 vezes, foram adicionados aos pocinhos $100 \mu \mathrm{L}$ de IgY, na concentração de $5 \mu \mathrm{g} / \mathrm{mL}$. Seguiram-se um período de incubação da placa de 90 min a $37{ }^{\circ} \mathrm{C}$ e lavagem da mesma com PBS-Tween por 3 vezes. Colocaram-se, então, $100 \mu \mathrm{L}$ de imunoglobulina $\mathrm{G}$ de cabra contra $\operatorname{IgY}$ de galinha conjugada com fosfatase alcalina, diluída 1:35.000 em PBS-Tween, em cada pocinho. A placa foi novamente incubada a $37^{\circ} \mathrm{C}$ por $90 \mathrm{~min}$ e depois de lavada da mesma forma anterior, cada pocinho recebeu $100 \mu \mathrm{L}$ de p-fosfato de nitrofenil (uma pastilha dissolvida em $6 \mathrm{~mL}$ de tampão dietanolamina $\mathrm{pH} 9,8$ ). Incubou-se a placa à temperatura ambiente e escuro durante 20 min para permitir a ocorrência da reação enzimática, após o que, determinou-se a absorbância de cada pocinho a $405 \mathrm{~nm}$, utilizando-se de um leitor de ELISA. A reação foi considerada positiva quando o valor médio da absorbância a $405 \mathrm{~nm}$ excedeu em duas vezes o valor médio da absorbância do extrato da planta sadia (Sutula et al., 1986).

\subsubsection{Efeito do ambiente e do intervalo de tempo entre tratamento-inoculação sobre a proteção de plantas de maracujá contra o PWV}

Foram preparadas mudas de maracujá, em bandejas contendo substrato, no interior de um telado de madeira coberto com sombrite que reduz em $70 \%$ a radiação solar. Após o transplantio para vasos contendo terra e esterco curtido, as mudas foram divididas em dois lotes. Um permaneceu no interior do telado-sombrite, e outro foi levado para casa de vegetação convencional. As plantas, nos dois lotes, foram tratadas com água ou extratos de cogumelos aos 6 ou 3 dias antes da inoculação viral, quando se encontravam com seis a sete folhas expandidas. A inoculação foi realizada mecanicamente em uma folha pré-tratada por planta. Ao longo do experimento, registraram-se as temperaturas máximas em cada local, diariamente. A avaliação da incidência da virose realizou-se 30 dias após a inoculação. 


\subsubsection{Transmissão do PWV para plantas de maracujá, utilizando-se o vetor Myzus persicae}

As plantas foram tratadas com água destilada ou com extratos dos cogumelos, quando se encontravam com sete a oito folhas expandidas. Todas as folhas de cada planta foram tratadas, utilizando-se $15 \mathrm{~mL}$ do tratamento por planta. Após 5 dias, realizou-se o teste de transmissão do vírus. Para tal, pulgões da espécie $M$. persicae, cuja colônia havia crescido em plantas de pimentão, foram retirados cuidadosamente das folhas de pimentão, com auxílio de um pincel, e depositados no interior de uma caixinha plástica, onde permaneceram em jejum por $30 \mathrm{~min}$. Posteriormente, os pulgões foram colocados para se alimentarem durante $30 \mathrm{~min}$ em uma folha de maracujá infectada com o PWV, e então, transferidos para as plantas de maracujá sadias, previamente tratadas. Cada planta recebeu cinco pulgões. Duas horas depois, as plantas foram pulverizadas com o inseticida Decis (1 mL do produto comercial em 3 litros de água) para a eliminação dos vetores. A avaliação dos resultados foi realizada aos 15 e 30 dias após a transmissão, através da quantificação da incidência da virose nos diferentes tratamentos.

\subsubsection{Efeito dos extratos dos cogumelos na infectividade do PWV}

Dois gramas de folhas de maracujá infectadas com o PWV foram macerados em almofariz, na presença de $25 \mathrm{~mL}$ de água milli $\mathrm{Q}$ (diluição do $\mathrm{PWV}=1: 12,5$ ). A suspensão contendo o vírus foi dividida em alíquotas iguais, às quais adicionaram-se água destilada ou os extratos aquosos dos cogumelos. A diluição final da suspensão contendo o PWV foi de 1:20 ou 1:40, dependendo do experimento. Os extratos dos isolados dos cogumelos foram adicionados na suspensão viral em quantidades que resultaram em concentrações finais de 0,20 ou $40 \%$ de extrato (v/v), equivalentes às concentrações utilizadas no tratamento das plantas de maracujá. Plantas de Chenopodium quinoa, hospedeira de lesão local do vírus, foram inoculadas mecanicamente com os tratamentos obtidos. Cada tratamento contou com, no mínimo, quatro repetições, sendo uma repetição representada por um vaso com duas plantas. Três a quatro folhas por planta, da posição mediana, foram escolhidas para a inoculação. As plantas foram mantidas em condições de casa de vegetação e a avaliação foi realizada 
pela contagem do número de lesões locais encontrado em cada folha inoculada, 12 dias após a inoculação.

\subsubsection{Proteção sistêmica de C. quinoa contra o PWV}

Plantas de C. quinoa, apresentando $35-40 \mathrm{~cm}$ de altura, foram tratadas com água destilada ou extratos aquosos de basidiocarpos dos cogumelos (6 mL/planta). Os tratamentos foram realizados nas folhas das partes inferior e mediana das plantas. Cinco dias após os tratamentos, três a quatro folhas da parte superior das plantas foram inoculadas mecanicamente com PWV (1:40), com o objetivo de se avaliar o efeito sistêmico dos extratos contra o vírus em um hospedeiro de lesão local. Cada tratamento contou com, no mínimo, cinco repetições, sendo uma repetição representada por um vaso com duas plantas. As plantas foram mantidas em condições de casa de vegetação e a avaliação foi realizada pela contagem do número de lesões locais encontrado em cada folha inoculada, 12 dias após a inoculação.

\subsection{Resultados}

\subsubsection{Proteção de plantas de maracujá inoculadas mecanicamente com o PWV}

A aplicação dos extratos de basidiocarpos de L. edodes, 10 dias antes da inoculação das plantas com o PWV, não reduziu a incidência da virose, independente do isolado de shiitake e da concentração de extrato utilizados (Tabela 1). 
Tabela 1. Efeito local dos extratos aquosos de basidiocarpos dos isolados LE 96/17, LE 96/22 e LE JAB-K de Lentinula edodes sobre a incidência da virose provocada pelo PWV em plantas de maracujá. Tratamentos realizados 10 dias antes da inoculação viral

\begin{tabular}{lcc}
\hline Tratamentos & $\begin{array}{r}\text { № plantas doentes / } \\
\text { № plantas inoculadas* }\end{array}$ & $\begin{array}{c}\text { Incidência da virose } \\
(\%)\end{array}$ \\
\hline Água & $5 / 5$ & 100 \\
LE 96/17 (20\%) & $5 / 5$ & 100 \\
LE 96/17 (40\%) & $5 / 5$ & 100 \\
LE 96/22 (20\%) & $5 / 5$ & 100 \\
LE 96/22 (40\%) & $5 / 5$ & 100 \\
LE JAB-K (20\%) & $5 / 5$ & 100 \\
LE JAB-K (40\%) & $5 / 5$ & 100
\end{tabular}

*Foram inoculadas mecanicamente duas folhas com PWV (1:40) por planta

Diminuindo-se o intervalo de tempo entre tratamento-inoculação para 5 dias, os extratos de basidiocarpos dos isolados ABL 99/26 e ABL 99/28 de A. blazei, na concentração de $40 \%(\mathrm{v} / \mathrm{v})$, inibiram a infecção viral em todas as plantas pré-tratadas, com redução de 100\% na incidência da doença, enquanto o isolado ABL 99/29 foi menos eficiente, reduzindo em $60 \%$ a incidência da virose. Os filtrados de crescimento micelial (FCM) de dois isolados de L. edodes (LE 95/01 e LE 96/17) não apresentaram efeito algum na infectividade viral. O FCM de LE 96/22 teve o mesmo efeito do seu controle mais imediato (o meio de cultivo $\mathrm{BD}$ ), com redução de $40 \%$ na incidência da doença em relação às plantas tratadas com água (Tabela 2 ). 
Tabela 2. Incidência da virose provocada pelo PWV em plantas de maracujá tratadas com água ou com preparações dos cogumelos Lentinula edodes e Agaricus blazei, utilizadas a $40 \%$ (v/v), 5 dias antes da inoculação com o vírus

\begin{tabular}{lcc}
\hline Tratamentos & $\begin{array}{r}\text { No plantas doentes / } \\
\text { No plantas inoculadas* }\end{array}$ & $\begin{array}{c}\text { Incidência da virose } \\
(\%)\end{array}$ \\
\hline Água & $5 / 7$ & 71,4 \\
Batata-dextrose & $3 / 7$ & 42,8 \\
FCM 95/01** & $5 / 7$ & 71,4 \\
FCM 96/17** & $5 / 7$ & 71,4 \\
FCM 96/22** & $3 / 7$ & 42,8 \\
ABL 99/26*** & $0 / 7$ & 0 \\
ABL 99/28*** & $0 / 7$ & 0 \\
ABL 99/29*** & $2 / 7$ & 28,5 \\
\hline
\end{tabular}

*Foram inoculadas mecanicamente duas folhas com PWV (1:40) por planta

**FCM $=$ filtrado de crescimento micelial de isolados de L. edodes, utilizados a $40 \%$ $(\mathrm{v} / \mathrm{v})$

*** $\mathrm{ABL}$ (A. blazei): extratos aquosos do basidiocarpo de isolados de A. blazei, utilizados a $40 \%(\mathrm{v} / \mathrm{v})$

O teste serológico DAS-ELISA indireto, realizado a partir de amostras de plantas que foram utilizadas no experimento ilustrado na Tabela 2 , mostrou que a avaliação de sintomas pode ser confiável para se apontar uma planta como doente (com infecção por PWV) ou como sadia. Pela Tabela 3, pode-se notar que houve uma correlação total entre presença de sintomas da virose (avaliação visual) e presença de vírus na planta (avaliação por DAS-ELISA indireto). Isso foi importante para demonstrar que as plantas sem sintomas aparentes da virose de fato não estavam infectadas com o vírus. 
Tabela 3. Comparação entre a avaliação visual e o teste serológico DAS-ELISA quanto à identificação de plantas de maracujá infectadas com o PWV. As plantas foram tratadas com água ou preparações dos cogumelos Agaricus blazei e Lentinula edodes, e inoculadas mecanicamente com o vírus, 5 dias depois

\begin{tabular}{|c|c|c|c|c|c|c|c|}
\hline $\begin{array}{l}\text { Trata- } \\
\text { mentos }\end{array}$ & $\begin{array}{r}\text { Planta } \\
n^{\circ}\end{array}$ & $\begin{array}{c}\text { Avaliação } \\
\text { visual* }\end{array}$ & $\begin{array}{c}\text { DAS- } \\
\text { ELISA** }\end{array}$ & $\begin{array}{c}\text { Trata- } \\
\text { mentos }\end{array}$ & $\begin{array}{r}\text { Planta } \\
n^{\circ}\end{array}$ & $\begin{array}{c}\text { Avaliação } \\
\text { visual }\end{array}$ & $\begin{array}{l}\text { DAS- } \\
\text { ELISA }\end{array}$ \\
\hline \multirow{7}{*}{ Água } & 1 & + & $0,593(+)$ & \multirow{7}{*}{$\begin{array}{l}\text { FCM } \\
96 / 22\end{array}$} & 1 & + & $0,523(+)$ \\
\hline & 2 & + & $0,514(+)$ & & 2 & - & $0,087(-)$ \\
\hline & 3 & + & $0,457(+)$ & & 3 & + & $\mathrm{Nd}$ \\
\hline & 4 & - & $0,077(-)$ & & 4 & - & $0,078(-)$ \\
\hline & 5 & - & $0,069(-)$ & & 5 & + & $0,390(+)$ \\
\hline & 6 & + & $0,534(+)$ & & 6 & - & $0,083(-)$ \\
\hline & 7 & + & $0,375(+)$ & & 7 & - & $0,076(-)$ \\
\hline \multirow{7}{*}{$\begin{array}{l}\text { batata- } \\
\text { dextrose }\end{array}$} & 1 & - & $0,073(-)$ & \multirow{7}{*}{$\begin{array}{l}\text { ABL } \\
99 / 26\end{array}$} & 1 & - & $0,090(-)$ \\
\hline & 2 & + & $0,508(+)$ & & 2 & - & $0,095(-)$ \\
\hline & 3 & - & $0,087(-)$ & & 3 & - & $0,084(-)$ \\
\hline & 4 & - & $0,075(-)$ & & 4 & - & $0,081(-)$ \\
\hline & 5 & - & $0,085(-)$ & & 5 & - & $0,089(-)$ \\
\hline & 6 & + & $\mathrm{Nd}^{* * *}$ & & 6 & - & $0,087(-)$ \\
\hline & 7 & + & $\mathrm{Nd}$ & & 7 & - & $0,081(-)$ \\
\hline \multirow{7}{*}{$\begin{array}{l}\text { FCM } \\
95 / 01\end{array}$} & 1 & + & $\mathrm{Nd}$ & \multirow{7}{*}{$\begin{array}{l}\text { ABL } \\
99 / 28\end{array}$} & 1 & - & $0,092(-)$ \\
\hline & 2 & + & $\mathrm{Nd}$ & & 2 & - & $0,083(-)$ \\
\hline & 3 & - & $0,083(-)$ & & 3 & - & $0,079(-)$ \\
\hline & 4 & + & $\mathrm{Nd}$ & & 4 & - & $0,074(-)$ \\
\hline & 5 & + & $0,498(+)$ & & 5 & - & $0,091(-)$ \\
\hline & 6 & - & $0,070(-)$ & & 6 & - & $0,091(-)$ \\
\hline & 7 & + & $\mathrm{Nd}$ & & 7 & - & $0,087(-)$ \\
\hline \multirow{7}{*}{$\begin{array}{l}\text { FCM } \\
96 / 17\end{array}$} & 1 & + & $\mathrm{Nd}$ & \multirow{7}{*}{$\begin{array}{l}\text { ABL } \\
99 / 29\end{array}$} & 1 & + & $0,519(+)$ \\
\hline & 2 & + & $\mathrm{Nd}$ & & 2 & - & $0,075(-)$ \\
\hline & 3 & + & $\mathrm{Nd}$ & & 3 & - & $0,090(-)$ \\
\hline & 4 & + & $\mathrm{Nd}$ & & 4 & - & $0,097(-)$ \\
\hline & 5 & + & $0,550(+)$ & & 5 & - & $0,087(-)$ \\
\hline & 6 & - & $0,084(-)$ & & 6 & - & $0,092(-)$ \\
\hline & 7 & - & $0,097(-)$ & & 7 & + & $0,510(+)$ \\
\hline
\end{tabular}

* Presença (+) ou ausência (-) de sintomas da virose nas folhas mais novas

** Valor médio de dois pocinhos, obtidos em leitor de ELISA a $405 \mathrm{~nm}$, após a reação de extrato foliar com antissoro para PWV. Consideraram-se infectadas $(+)$ as plantas que apresentaram reações com valores $\geq 0,190$ (duas vezes o valor das plantas sadias)

$* * * \mathrm{Nd}=$ não-determinado 
Com os resultados do teste anterior, passourse a concentrar os estudos nos extratos aquosos obtidos de basidicarpos de A. blazei e de L. edodes. Em novo experimento, o tratamento de plantas de maracujá com extratos do isolado ABL 99/28 de A. blazei confirmou os resultados anteriores, com redução de $85 \%$ na incidência da virose quando a inoculação viral foi realizada em folhas previamente tratadas (efeito local). No entanto, o efeito sistêmico do isolado foi pouco pronunciado (Tabela 4).

Tabela 4. Incidência da virose provocada pelo PWV em plantas de maracujá tratadas com água ou com extratos de basidiocarpos do isolado ABL 99/28 de Agaricus blazei, utilizados a $40 \%$ (v/v), 5 dias antes da inoculação viral

\begin{tabular}{lcc}
\hline Tratamentos & $\begin{array}{c}\text { No plantas doentes / } \\
\text { No plantas inoculadas* }\end{array}$ & $\begin{array}{c}\text { Incidência da virose } \\
(\%)\end{array}$ \\
\hline Água & $13 / 16$ & 81,25 \\
ABL 99/28 - efeito local & $1 / 8$ & 12,50 \\
ABL 99/28 - efeito sistêmico & $5 / 8$ & 62,50
\end{tabular}

*Foram inoculadas mecanicamente duas folhas com PWV (1:40) por planta

Os extratos aquosos de basidicarpos de L. edodes, utilizados a $40 \%$ (v/v) e aplicados 5 dias antes da inoculação com PWV, também proporcionaram uma proteção local significativa, embora menor em relação à conferida por isolados de A. blazei em outros testes. Por outro lado, a proteção sistêmica por parte de L. edodes mostroutse de menor intensidade (Tabela 5).

A dependência da concentração do extrato aquoso de basidiocarpo para a ocorrência de proteção localizada do maracujazeiro ficou claramente estabelecida após o emprego de diferentes doses de extratos em um mesmo experimento. As concentrações de extratos inferiores a $40 \%$ não foram eficientes para reduzir a incidência da virose (Tabela 6). 
Tabela 5. Efeitos local e sistêmico dos extratos de basidiocarpos dos isolados LE 95/01 e LE 96/22 de Lentinula edodes, a 40\% (v/v), sobre a incidência da virose provocada pelo vírus do endurecimento dos frutos (PWV) em plantas de maracujá. Tratamentos realizados 5 dias antes da inoculação viral

\begin{tabular}{lcc}
\hline Tratamentos & $\begin{array}{r}\text { № plantas doentes / } \\
\text { No plantas inoculadas* }\end{array}$ & $\begin{array}{c}\text { Incidência da virose } \\
(\%)\end{array}$ \\
\hline Água & 12 / 12 & 100 \\
LE 95/01 - efeito local & 2 / 6 & 33,3 \\
LE 95/01 - efeito sistêmico & 3 / 6 & 50,0 \\
LE 96/22 - efeito local & 2 / 6 & 33,3 \\
LE 96/22 - efeito sistêmico & $4 / 6$ & 66,6
\end{tabular}

*Foi inoculada mecanicamente uma folha com PWV (1:40) por planta

Tabela 6. Efeito local da concentração dos extratos aquosos de basidiocarpos dos isolados LE 95/01 de Lentinula edodes e ABL 99/26 de Agaricus blazei sobre a incidência da virose provocada pelo PWV em plantas de maracujá. Tratamentos realizados 6 dias antes da inoculação viral

\begin{tabular}{lcc}
\hline Tratamentos & $\begin{array}{r}\text { № plantas doentes / } \\
\text { No plantas inoculadas* }\end{array}$ & $\begin{array}{c}\text { Incidência da virose } \\
(\%)\end{array}$ \\
\hline Água & $6 / 6$ & 100 \\
LE 95/01 (10\%) & $6 / 6$ & 100 \\
LE 95/01 (20\%) & $6 / 6$ & 100 \\
LE 95/01 (40\%) & $4 / 6$ & 66,6 \\
ABL 99/26 (10\%) & $6 / 6$ & 100 \\
ABL 99/26 (20\%) & $6 / 6$ & 100 \\
ABL 99/26 (40\%) & $3 / 6$ & 50 \\
\hline
\end{tabular}

*Foram inoculadas mecanicamente duas folhas com PWV (1:40) por planta 


\subsubsection{Confirmação da ausência de efeito sistêmico dos extratos dos cogumelos contra o PWV em maracujazeiro}

Em concordância com os resultados dos primeiros testes, não se obteve proteção sistêmica das plantas de maracujá contra o PWV, utilizando-se extratos de cogumelos, independente do intervalo de tempo entre tratamento-inoculação e da concentração de extrato utilizada. Na Tabela 7, nota-se que os extratos de LE 95/01 e ABL 99/28, que conferem um bom nível de proteção local quando aplicados antes da inoculação com o PWV, não apresentaram efeito sistêmico em um intervalo de tempo de 6 dias. Aumentando-se o intervalo para 10 dias, a ausência de proteção sistêmica por parte dos cogumelos ficou mais evidente (Tabela 8).

Tabela 7. Efeito sistêmico dos extratos aquosos de basidiocarpos dos isolados LE 95/01 de Lentinula edodes e ABL 99/28 de Agaricus blazei, utilizados a 20\% (v/v), sobre a incidência da virose provocada pelo PWV em plantas de maracujá. Tratamentos realizados 6 dias antes da inoculação viral

\begin{tabular}{lcc} 
Tratamentos & $\begin{array}{r}\text { No plantas doentes / } \\
\text { No plantas inoculadas* }\end{array}$ & $\begin{array}{c}\text { Incidência da virose } \\
(\%)\end{array}$ \\
\hline Água & $8 / 8$ & 100 \\
LE 95/01 & $7 / 8$ & 87 \\
ABL 99/28 & $6 / 8$ & 75
\end{tabular}

\footnotetext{
*Foi inoculada mecanicamente uma folha com PWV (1:40) por planta
} 
Tabela 8. Efeito sistêmico dos extratos aquosos de basidiocarpos dos isolados LE 96/17 e LE JAB-K de Lentinula edodes, e dos isolados ABL 97/11 e ABL 99/29 de Agaricus blazei, utilizados a $40 \%$ (v/v), sobre a incidência da virose provocada pelo PWV em plantas de maracujá. Tratamentos realizados 10 dias antes da inoculação viral

\begin{tabular}{lcc}
\hline Tratamentos & $\begin{array}{r}\text { № plantas doentes / } \\
\text { No plantas inoculadas* }\end{array}$ & $\begin{array}{c}\text { Incidência da virose } \\
(\%)\end{array}$ \\
\hline Água & $6 / 7$ & 85 \\
LE 96/17 & $7 / 7$ & 100 \\
LE JAB-K & $6 / 7$ & 85 \\
ABL 97/11 & $7 / 7$ & 100 \\
ABL 99/29 & $6 / 7$ & 85 \\
LE 96/17 + ABL 97/11 & $6 / 7$ & 85 \\
LE JAB-K + ABL 99/29 & $6 / 7$ & 85
\end{tabular}

*Foram inoculadas mecanicamente duas folhas com PWV (1:40) por planta

\subsubsection{Efeito do nitrogênio, do ambiente e do intervalo de tempo entre tratamento- inoculação sobre a proteção de plantas de maracujá contra o PWV}

A proteção local conferida em maracujá pelos isolados LE 95/01 e ABL 99/26, quando utilizados a $40 \%$ (v/v), não aconteceu em uma situação favorável ao vírus. A adubação nitrogenada, realizada próximo à inoculação, resultou praticamente em $100 \%$ de plantas, tratadas ou não, mostrando fortes sintomas da virose (Tabela 9).

$\mathrm{O}$ experimento conduzido em duas condições ambientais distintas mostrou que plantas de maracujá mantidas, em pleno verão, no interior de uma casa de vegetação convencional, onde a média das temperaturas máximas durante a realização do experimento atingiu $42{ }^{\circ} \mathrm{C}$, foram protegidas pelos extratos aquosos de basidiocarpos de LE 95/01 e de ABL 99/26 a 40\% (v/v) mais eficientemente do que plantas mantidas em um telado de madeira coberto com sombrite, onde a média das máximas foi $34{ }^{\circ} \mathrm{C}$ (Tabela 10). 
Quanto ao efeito do intervalo de tempo entre os tratamentos com cogumelos e a inoculação viral, houve também influência ambiental. Na casa de vegetação, os extratos reduziram a incidência da virose em magnitude semelhante, a 3 ou 6 dias de intervalo. Por outro lado, no sombrite, o isolado LE 95/01 só foi eficaz no controle da virose no intervalo de tempo mais curto, enquanto a eficiência do ABL 99/26 foi relativamente pequena, independente do intervalo de tempo (Tabela 10).

Tabela 9. Efeito local dos extratos aquosos de basidiocarpos dos isolados LE 95/01 de Lentinula edodes e ABL 99/26 de Agaricus blazei, utilizados a 40\% (v/v), sobre a incidência da virose provocada pelo PWV em plantas de maracujá. Tratamentos realizados 3 dias antes da inoculação viral

\begin{tabular}{lcc}
\hline Tratamentos & $\begin{array}{r}\text { No plantas doentes / } \\
\text { № plantas inoculadas* }\end{array}$ & $\begin{array}{c}\text { Incidência da virose } \\
(\%)\end{array}$ \\
\hline Água & $10 / 10$ & 100 \\
LE 95/01 & $19 / 20$ & 95 \\
ABL 99/26 & $20 / 20$ & 100 \\
\hline
\end{tabular}

*Foram inoculadas mecanicamente duas folhas com PWV (1:40) por planta

Obs.: foi realizada adubação com sulfato de amônio (1g/vaso), na data de realização dos tratamentos, ou seja, 3 dias antes da inoculação das plant as com o vírus 
Tabela 10. Efeito do ambiente e do intervalo de tempo entre tratamento-inoculação sobre a proteção local de plantas de maracujá contra o PWV, conferida por extratos aquosos de basidiocarpos dos isolados LE 95/01 de Lentinula edodes e ABL 99/26 de Agaricus blazei, utilizados a $40 \%$ (v/v)

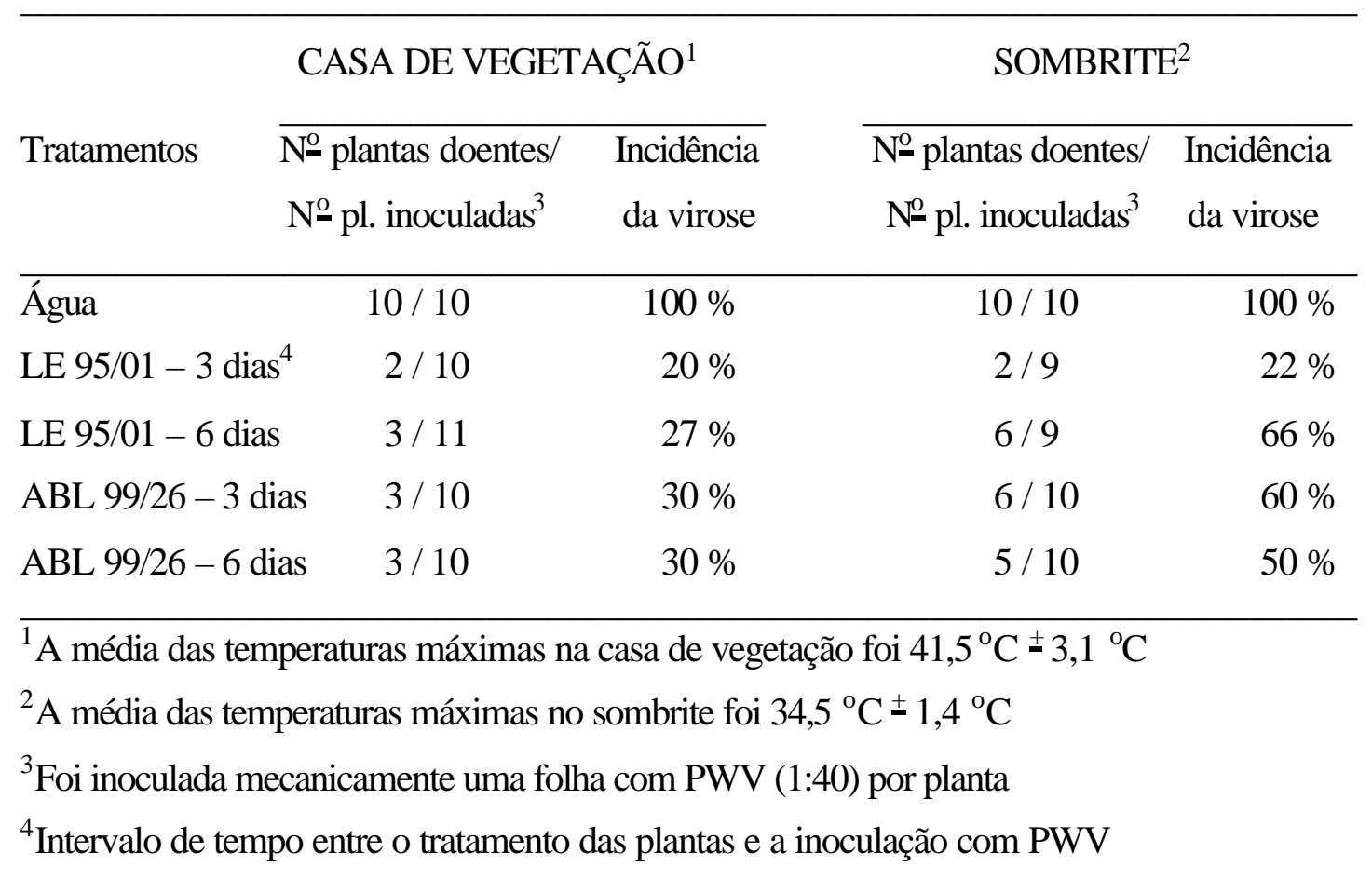

\subsubsection{Transmissão do PWV por M. persicae}

A exemplo dos experimentos onde a inoculação das plantas de maracujá foi mecânica, os testes de transmissão viral com vetor foram realizados com plantas apresentando seis a sete folhas expandidas. Além disso, procurou-se testar os isolados de L. edodes e de A. blazei que se mostraram eficientes na proteção local de maracujá contra o vírus, utilizando-se as mesmas concentrações de extrato e os mesmos intervalos de tempo empregados nos testes de transmissão mecânica.

Os resultados da Tabela 11, no entanto, não permitem tecer maiores conclusões sobre o efeito dos cogumelos na incidência da virose transmitida pelo pulgão $M$. persicae, devido às baixas taxas de transmissão observadas nos diferentes tratamentos. 
Considerando os dois experimentos, a taxa média de transmissão foi aproximadamente de apenas $25 \%$.

Tabela 11. Transmissão do PWV, através do afídeo vetor, para plantas de maracujá contendo seis a sete folhas expandidas, previamente tratadas com extratos aquosos de basidiocarpos de Lentinula edodes e de Agaricus blazei ou com acibenzolar S-metil (ASM)

Tratamentos № plantas doentes / № plantas utilizadas na transmissão*
Incidência da virose

\section{( $1^{0}$ experimento)}

Água

$2 / 7$

28,5

LE 95/01 (40\%)

$2 / 7$

28,5

ABL 99/26 (40\%)

$3 / 7$

42,8

LE $01+$ ABL 26**

$1 / 7$

14,2

ASM - 50 ppm

$1 / 7$

14,2

\section{( $2^{0}$ experimento)}

Água

$1 / 6$

16,6

LE 95/01 (20\%)

$1 / 6$

16,6

ABL 99/28 (20\%)

$2 / 6$

33,2

LE $01+$ ABL 28**

$2 / 6$

\footnotetext{
*Transmissão realizada pela colocação de cinco pulgões da espécie Myzus persicae por planta no $1^{\circ}$ experimento e 10/planta no segundo experimento. Avaliação realizada 30 dias após a transmissão

**Mistura de extratos dos isolados em proporções iguais
} 


\subsubsection{Efeito dos extratos dos cogumelos na infectividade do PWV e na proteção sistêmica de $C$.quinoa}

Em três experimentos independentes, observou-se que todos os isolados testados (LE 96/17, LE 96/22, ABL 97/11 e ABL 99/26) inibiram a infectividade do PWV, avaliada através do número médio de lesões locais presentes nas folhas de $C$. quinoa inoculadas com suspensão viral misturada aos extratos dos cogumelos.

O efeito inibitório foi um pouco mais pronunciado na concentração de $40 \%$ de extrato de basidiocarpos em relação à de 20\%, com exceção do isolado LE 96/22. No caso de ABL 99/26, um dos isolados eficientes na proteção local de maracujá, a redução na infectividade do PWV ocasionada pelo extrato aquoso do basidiocarpo foi superior a $50 \%$ (Tabela 12).

Tabela 12. Efeito dos extratos aquosos de basidiocarpos de Lentinula edodes e de Agaricus blazei na infectividade do PWV em Chenopodium quinoa

Tratamentos Número médio de lesões locais*

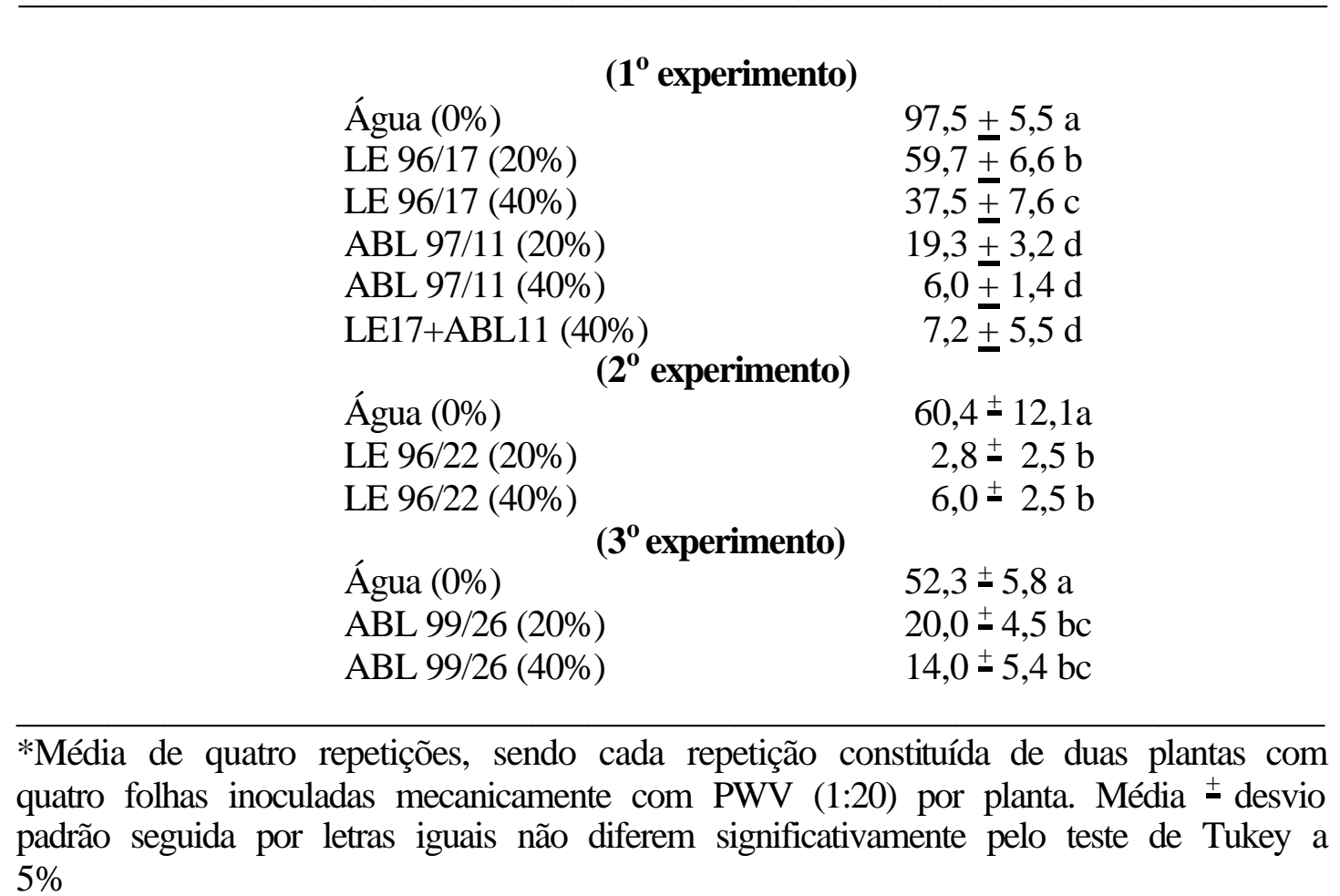


10
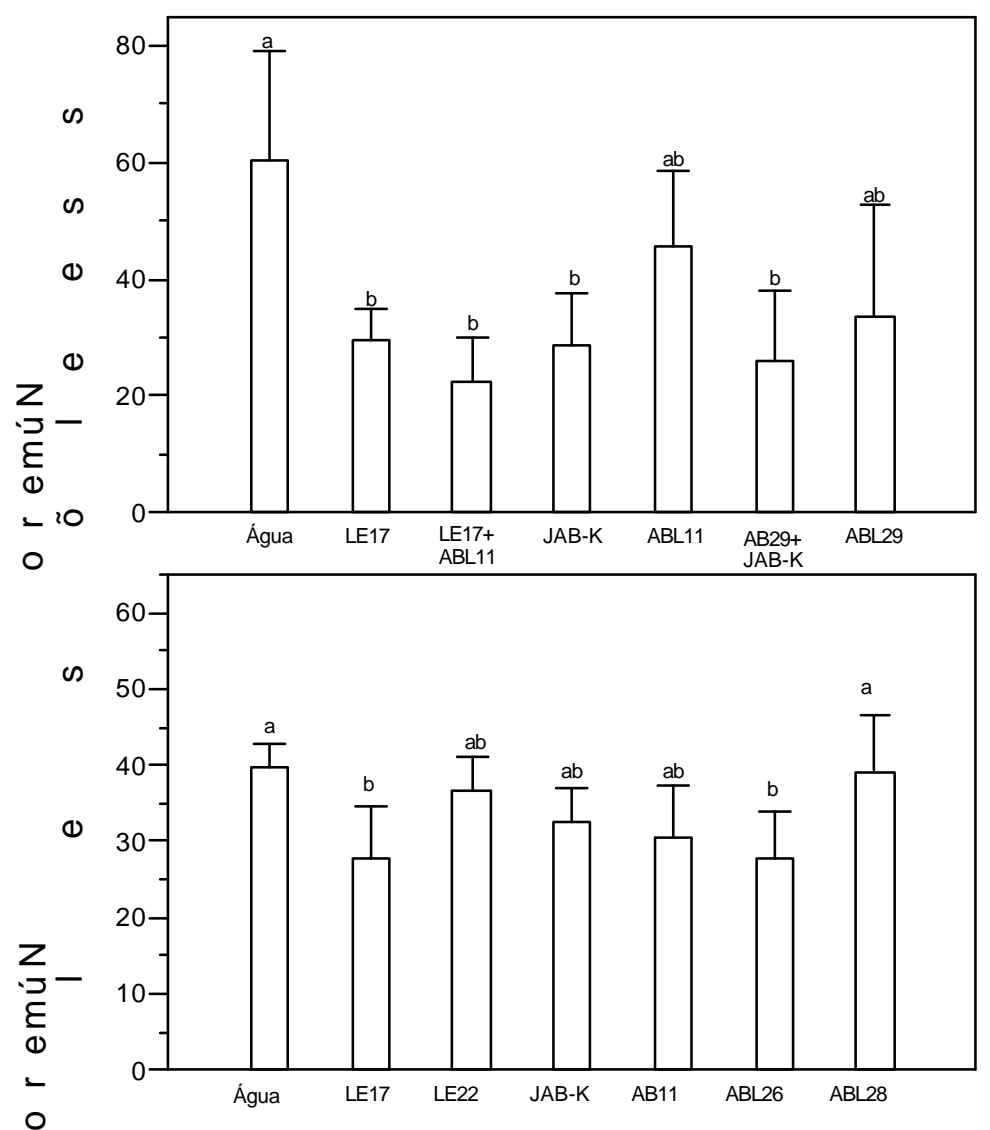

Figura 1 - Efeito sistêmico dos extratos aquosos de basidiocarpos dos isolados LE 96/17, LE 96/22 e LE JAB-K de Lentinula edodes, e dos isolados ABL 97/11, ABL 99/26, ABL 99/28 e ABL 99/29 de Agaricus blazei, utilizados a 20\% (v/v), no número de lesões locais provocado pelo PWV em Chenopodium quinoa, em dois experimentos independentes

Quanto ao efeito sistêmico dos extratos de cogumelos contra PWV em C. quinoa, os isolados LE 96/17 e ABL 99/26 reduziram significativamente o número de lesões locais em folhas não diretamente tratadas (Figura 1). Portanto, existe a possibilidade de estar ocorrendo indução de resistência sistêmica na planta. 


\subsection{Discussão}

Os extratos aquosos de basidiocarpos de L. edodes e de A. blazei conferiram proteção local em plantas de maracujá contra o PWV, mas não sistêmica. A proteção local foi dependente da concentração do extrato. Dessa forma, a idéia que surgiu foi a de que os cogumelos atuariam diretamente sobre as partículas virais, inibindo a infectividade do vírus. E de fato essa hipótese foi confirmada, utilizando-se um hospedeiro de lesão local do PWV, a espécie C. quinoa, a qual permite quantificar o efeito inibitório de um tratamento.

Muitos trabalhos mostraram a ocorrência de inibidores virais em microrganismos, principalmente em estudos envolvendo o TMV e plantas de fumo. Grohmann \& Musumeci (1972) encontraram um inibidor de infecção de TMV no filtrado de cultura do fungo Aspergillus flavus, que reduziu em $92 \%, 82 \%$ e $47 \%$ a infectividade do TMV em Nicotiana glutinosa, Phaseolus vulgaris e Datura stramonium, respectivamente, e apresentou alta atividade inibitória mesmo em diluições elevadas. Micolaminarana, uma $\beta-1,3$ glucana purificada a partir do citoplasma de Phytophthora megasperma, reduziu a infectividade do TMV (Zinnen et al., 1991), bem como inibiu a infectividade de quatro linhagens do Cauliflower mosaic virus (CaMV) em D. stramonium e a de Tomato spotted wilt virus (TSWV) em N. glutinosa (Heinkel et al., 1992). Metabólitos produzidos pelas cianobactérias Synechococcus leopoliensis e Nostoc sp, assim como a suspensão de células desses microrganismos, também atuaram sobre as partículas do TMV (Di Piero et al., 2000). Para o PWV, são poucos os relatos da produção, por parte de microrganismos como L. edodes e A. blazei, de compostos inibidores da infectividade viral.

Além do efeito dos extratos de basidiocarpo diretamente sobre PWV, alguns indícios apontaram para o fato de que a proteção local em maracujá não é resultado exclusivo do efeito sobre o vírus, mas que os extratos dos cogumelos podem estar atuando, ainda que em menor intensidade, sobre a planta. Um desses indícios foi o melhor desempenho dos extratos dos cogumelos nas plantas mantidas em casa de vegetação em relação às que permaneceram no telado-sombrite É de se esperar que, no sombrite, o efeito residual da aplicação dos extratos sobre as plantas fosse maior, já que 
fatores como elevadas intensidade luminosa e temperatura não ocorrem, os quais poderiam degradar compostos antivirais presentes nos extratos. Portanto, caso o efeito dos extratos fosse apenas nas partículas virais quando da infecção, a porcentagem de redução na incidência da virose deveria ser maior no sombrite, o que não aconteceu.

Se o efeito dos extratos de basidiocarpos sobre as plantas de maracujá necessita de outros estudos, por outro lado, foi demonstrado que extratos de alguns dos isolados dos cogumelos promoveram proteção sistêmica contra o PWV em C. quinoa, a qual pode ser resultado de uma indução de resistência. A indução de resistência, de forma geral, ocorre com maior freqüência em materiais vegetais que apresentam um certo nível de resistência genética. No caso, C. quinoa apresenta fatores genéticos que impedem a movimentação sistêmica do PWV e com isso tem maiores condições de responder positivamente a indutores.

Resultados semelhantes aos aqui apresentados foram obtidos por Pennazio \& Roggero (1988). Trabalhando com Nicotiana tabacum, cultivar White Burley, os autores mostraram que a inoculação da quarta folha com vírus causadores de lesões locais, no caso o TNV e o ToMV, induziu resistência sistêmica contra esses mesmos vírus quando a quinta folha das plantas foi inoculada 5 dias depois, porém não teve efeito sobre $\mathrm{PVY}^{\mathrm{N}}$ (linhagem necrótica), TMV e TRV (Tobacco rattle vírus), vírus que invadem sistemicamente White Burley.

Existe um grande número de estudos mostrando indução de resistência sistêmica contra vírus que provocam infeções localizadas, no entanto, a ineficiência contra vírus de invasão sistêmica tem resultado em pouco valor para o uso desses indutores no controle de viroses no campo. De forma que, a significativa proteção local contra o PWV, devido a um efeito antiviral dos extratos de cogumelos, e possivelmente a um efeito indutor de resistência vegetal, não mostra, até o momento, aplicação prática para o controle dessa problemática virose que atinge o maracujazeiro. Os afídeos vetores da doença no campo transmitem o vírus de forma não-persistente, através da picada de prova. Nesse caso, para controlar a virose, os extratos precisariam ter algum efeito no comportamento dos vetores, ou ativar mecanismos de defesa que sejam eficazes para 
impedir o estabelecimento do PWV, na concentração de vírus que o vetor normalmente transmite às plantas.

\subsection{Conclusões}

Os extratos aquosos de basidiocarpos dos cogumelos L. edodes e A. blazei possuem compostos inibidores da infectividade do PWV e ainda podem induzir resistência contra o vírus em $C$. quinoa, uma espécie vegetal onde o PWV não se estabelece sistemicamente. Até o momento, no entanto, esses extratos não se mostraram viáveis para o controle da virose em maracujazeiro. 


\section{PROTEÇÃO DE PLANTAS DE TOMATE CONTRA Xanthomonas vesicatoria UTILIZANDO EXTRATOS DOS COGUMELOS Lentinula edodes e Agaricus blazei}

\section{Resumo}

Os cogumelos Lentinula edodes e Agaricus blazei apresentam substâncias no corpo de frutificação (basidiocarpo) e no micélio com atividades antibióticas e imunoregulatórias, havendo ainda uma série de relatos sobre a atuação das mesmas no controle de doenças animais. Alguns trabalhos mostraram o potencial dos cogumelos para o controle de doenças em plantas. Os objetivos da pesquisa atual foram o de verificar o controle da mancha bacteriana do tomateiro, utilizando-se extratos aquosos de basidiocarpo dos cogumelos, e estudar o modo de ação dos materiais com atividade protetora. Os resultados mostraram que, de maneira geral, os isolados de L. edodes não controlaram a bacteriose. Por outro lado, um dos isolados de A. blazei, o isolado ABL 99/28, reduziu significativamente a severidade da bacteriose em dois de três testes conduzidos sob condições de casa de vegetação (proteção média da ordem de 45\%), quando o extrato de basidiocarpos foi aplicado a $10 \%$ (v/v), 5 dias antes da inoculação das plantas. Dobrando-se o inóculo bacteriano, de 0,15 para 0,3 unidades de absorbância a $600 \mathrm{~nm}$, a proteção conferida pelo isolado do cogumelo não foi verificada, enquanto o ativador de plantas, acibenzolar-S-metil (controle positivo) permaneceu altamente eficiente, proporcionando proteção acima de $80 \%$. Não foi demonstrada a inibição de $X$. vesicatoria por ABL 99/28, sendo que o crescimento bacteriano in vitro foi estimulado pelo extrato aquoso de basidiocarpos do isolado, utilizado na concentração que promoveu redução na doença. Plantas de tomate tratadas com o extrato de ABL 99/28 exibiram aumento na atividade de glucanases já no terceiro dia após o tratamento, 
enquanto a atividade de peroxidases não foi alterada. Com base nos resultados, sugere-se que o isolado ABL 99/28 de A. blazei induziu resistência em tomateiro contra Xanthomonas vesicatoria.

\section{Summary}

The mushrooms Lentinula edodes and Agaricus blazei have substances in the fruiting body and in the mycelia exhibiting antibiotic activity and others able to stimulate the immune system in animals. There are many reports about the performance of these substances in the control of animal diseases and a few showing the potential of the mushrooms for the control of diseases in plants. The objectives of the current work were to verify the control of the tomato bacterial spot by using aqueous extracts from mushrooms fruiting bodies, and to study the way of action of the extracts showing protecting activity. In a general way, the results indicated that the isolates of $L$. edodes did not control the bacterial disease. By the other hand, one isolate of A. blazei, named ABL 99/28, reduced the disease severity significantly in two of three tests carried out under greenhouse conditions, when the mushroom extract at $10 \%(\mathrm{v} / \mathrm{v})$ was applied 5 days before plant inoculation (the mean protection was around 45\%). By increasing the concentration of the bacterial cell suspension twice, (from 0,15 to 0,3 absorbance units at $600 \mathrm{~nm}$ ), the protecting effect of ABL 99/28 was lost, while the plants activator, acibenzolar-S-methyl (positive control), stayed highly efficient, reducing the disease in more than $80 \%$. The ABL 99/28 isolate did not inhibit X. vesicatoria, instead in vitro bacterial growth was stimulated by the aqueous extract from fruiting body of this isolate, used in the concentration that promoted reduction in disease severity. Tomato plants treated with the extract from ABL 99/28 exhibited increased glucanase activity in the third day after the treatment, while peroxidase activity was not changed. Based upon the results, it is suggested that the isolate ABL 99/28 of A. blazei induced resistance in tomato plants against $X$. vesicatoria. 


\subsection{Introdução}

A mancha bacteriana do tomateiro (Lycopersicon esculentum Mill.), causada por algumas espécies do gênero Xanthomonas, é uma das doenças mais importantes da cultura, podendo provocar significativas perdas, principalmente em ambientes quentes e úmidos. A bactéria pode atacar todos os tecidos aéreos da planta, reduzindo a produtividade pela destruição de tecido foliar, e pela derrubada de flores e frutos em formação, além de comprometer a qualidade dos frutos para o comércio (Lopes \& Santos, 1994).

Medidas preventivas tais como o uso de sementes e mudas livres do patógeno, a rotação de culturas, o manejo adequado da irrigação, a desinfestação de instrumentos de corte são muito importantes, uma vez que, estabelecida numa área com ambiente favorável à doença, o controle da bacteriose é difícil e as ações se restringem a aplicações de cúpricos, em conjunto com maneb, zineb e mancozeb ou estreptomicina. No entanto, a utilização repetida desses produtos tem provocado a seleção de linhagens bacterianas insensíveis aos mesmos (Adaskaveg \& Hine, 1985; Duval, 2003).

Sem dúvida, a utilização de materiais resistentes ao patógeno é uma importante medida dentro do manejo da doença. Fontes genéticas de resistência existem em plantas de tomate. Entretanto, a ampla diversidade genética da bactéria tem dificultado o desenvolvimento de uma resistência durável (Bouzar et al., 1999).

Nesse sentido, outras medidas se fazem necessárias para o manejo da doença. Medidas essas que tragam menor impacto ambiental e menor risco de seleção de linhagens resistentes. A indução de resistência apresenta esses atributos e o estudo desse fenômeno tem crescido nos últimos anos, resultando na disponibilidade comercial de vários ativadores de planta, entre os quais se destaca o acibenzolar-S-metil (ASM).

Experimentalmente, vários microrganismos têm mostrado potencial para induzir resistência contra doenças do tomateiro. Anfoka \& Buchenauer (1997) relataram a indução de resistência local e sistêmica em plantas de tomate contra Phytophthora infestans, agente causal da requeima, por meio da inoculação prévia com o Tobacco necrosis virus (TNV). A indução sistêmica de resistência foi dependente do intervalo de 
tempo entre o tratamento com o indutor e a inoculação com o patógeno, sendo que somente em intervalos superiores a 4 dias, o tratamento foi eficiente.

Resistência induzida contra Fusarium oxysporum f. sp. lycopersici foi obtida pela inoculação prévia do sistema radicular das plantas com a rizobactéria Pseudomonas fluorescens, linhagem 63-28 (M'piga et al., 1997). Nas plantas colonizadas pela rizobactéria, foram encontradas barreiras químicas e estruturais nas camadas mais externas do tecido radicular, abaixo dos sítios de penetração fúngica. Posteriormente, foram ativadas outras respostas relacionadas à indução de resistência, tais como a síntese de compostos fenólicos e quitinases, que contribuíram para restringir o crescimento do fungo fitopatogênico.

O fungo formador de micorriza arbuscular, Glomus mosseae, induziu resistência sistêmica em tecidos de tomate contra Phytophthora parasitica, a qual foi caracterizada pelo engrossamento de parede celular e pela formação de material rico em calose por volta das hifas de penetração de P. parasitica (Cordier et al., 1998).

Por sua vez, os cogumelos L. edodes e A. blazei apresentam substâncias presentes no basidiocarpo e no micélio que ativam o sistema imunológico em animais (Mizuno, 1995a). Entre essas substâncias, a lentinana, uma glucana obtida a partir de L. edodes, protegeu plantas de maracujá contra X. campestris pv. passiflorae, sem apresentar efeito direto contra a bactéria (Piccinin, 2000), indicando que a proteção provavelmente ocorreu através da indução de resistência.

Outras doenças bacterianas em plantas foram controladas por L. edodes. O lixiviado do cogumelo preveniu a murcha bacteriana do tomateiro provocada por Ralstonia solanacearum e a murcha de feijão-lima provocada por Clavibacter flaccumfaciens pv. flaccumfaciens, quando aplicado em vasos contendo uma mistura de vermiculita e substrato (1:1), previamente infestados com a bactéria patogênica à cultura em questão. Além disso, esse lixiviado inibiu o crescimento in vitro de bactérias fitopatogênicas, bem como de bactérias causadoras de doenças em animais (Pacumbaba et al., 1999). 
Dessa forma, o objetivo deste trabalho foi avaliar a proteção de plantas de tomate contra $X$. vesicatoria, utilizando preparações obtidas a partir dos cogumelos L. edodes e A. blazei, bem como determinar o mecanismo de ação envolvido na proteção.

\subsection{Material e Métodos}

6.2.1 Obtenção dos preparados de Lentinula edodes (shiitake) e de Agaricus blazei (cogumelo-do-sol)

Para a obtenção do extrato aquoso de cada isolado, o pó seco de basidiocarpos recebeu água destilada (14 $\mathrm{mL}$ para cada grama), e após $24 \mathrm{~h}$ de incubação a $4{ }^{\circ} \mathrm{C}$, a suspensão foi filtrada em filtro comum (gramatura: $8 \mathrm{~g} / \mathrm{cm}^{2}$ ) e centrifugada a $20.000 \mathrm{~g}$ por $25 \mathrm{~min}$, sendo o sobrenadante filtrado em membrana tipo Millipore (diâmetro do poro $=0,2 \mu \mathrm{m}$ ), sob condições assépticas. Os extratos aquosos brutos foram utilizados, após diluições, nos testes de proteção de plantas. Extrato aquoso a $10 \%$ v/v (10 mL de extrato bruto $+90 \mathrm{~mL}$ de água destilada) contém o equivalente a 7,15 mg pó seco de basidiocarpo/ $\mathrm{mL}$. Os isolados de L. edodes utilizados em tomateiro representam uma mistura de basidiocarpos produzidos em Eucaliptus grandis e em E. saligna. Os basidiocarpos dos isolados de $A$. blazei são provenientes de cultivo axênico.

\subsubsection{Planta e patógeno}

A maioria dos experimentos com tomate foi conduzido com a cultivar IPA-5, suscetível à bacteriose, e em alguns testes, utilizou-se a cultivar Agrocica-45, que apresenta resistência de campo. Tanto IPA-5 quanto Agrocica-45 são cultivares de tomate cuja produção é destinada à indústria. As sementes dessas cultivares foram fornecidas pelo Dr. Leonardo Giordano, do Centro Nacional de Pesquisa de Hortaliças (CNPH) da Embrapa, Brasília, DF.

Utilizourse o isolado de Xanthomonas vesicatoria CNPH 89, pertencente à coleção de trabalho do $\mathrm{CNPH} / \mathrm{Embrapa}$, o qual mostrou-se patogênico apenas ao tomateiro (Duval, 2003). A bactéria foi mantida a $26 \pm 2{ }^{\circ} \mathrm{C}$, em tampão fosfato $(8,6 \mathrm{mM}$ $\left.\mathrm{K}_{2} \mathrm{HPO}_{4} ; 7,4 \mathrm{mM} \mathrm{KH} \mathrm{PO}_{4} ; \mathrm{pH} 7,0\right)$. Quando da necessidade de inóculo bacteriano para 
a realização dos testes, alçadas contendo células bacterianas foram repicadas para o meio de cultivo nutriente-ágar (NA), e as placas incubadas a $30{ }^{\circ} \mathrm{C}$ durante 2 dias.

\subsubsection{Proteção de plantas de tomate em casa de vegetação}

Os extratos aquosos de basidiocarpos dos isolados de L. edodes e A. blazei foram aspergidos na planta toda (10 mL de extrato por planta contendo cinco a seis folhas) e, após um intervalo de tempo, dependendo do experimento, as plantas foram inoculadas em duas folhas da porção médio-apical com X. vesicatoria, realizando-se câmara úmida de 48 h. Para a inoculação, utilizaram-se duas concentrações da bactéria (valores de absorbância de células a $600 \mathrm{~nm}=0,15$ ou 0,30). Foram realizadas de cinco a seis repetições/tratamento. A avaliação da severidade da doença foi realizada aos 20 dias após a inoculação.

\subsubsection{Efeito in vitro de L. edodes e A. blazei sobre X. vesicatoria}

Tubos de ensaio contendo água destilada esterilizada receberam extratos aquosos de diferentes isolados dos cogumelos de modo a ser obtida uma concentração final de $10 \%(\mathrm{v} / \mathrm{v})$ de extrato. Posteriormente, adicionoutse $1 \mathrm{~mL}$ de uma suspensão de células de $X$. vesicatoria em cada tubo, ajustando-a de maneira que a concentração bacteriana final equivalesse a 0,15 unidades de absorbância a $600 \mathrm{~nm}$ (a mesma concentração bacteriana utilizada para a inoculação das plantas de tomate) ou para 0,05 unidades. Em outro ensaio, testaram-se diferentes concentrações de extratos de cogumelos, fixando-se a concentração bacteriana para 0,015 unidades de absorbância.

Os tubos contendo as misturas (extrato de um isolado + bactéria), cinco para cada tratamento, foram incubados no escuro, a $28{ }^{\circ} \mathrm{C}$ por $24 \mathrm{~h}$, após o que, alíquotas de 300 $\mu \mathrm{L}$ a partir de cada tubo foram pipetadas em placas de Petri contendo meio de cultivo bacteriano NA e espalhadas por toda a superfície do meio, utilizando alça de Drigalsky. As placas foram novamente incubadas no escuro, a $28{ }^{\circ} \mathrm{C}$, por $48 \mathrm{~h}$ e a avaliação dos resultados foi efetuada pela suspensão do crescimento bacteriano de cada placa em 30 $\mathrm{mL}$ de água destilada e leitura da transmitância em espectrofotômetro a $680 \mathrm{~nm}$. Para a construção dos gráficos, os valores de transmitância foram transformados em valores de 
absorbância, medida que apresenta relação diretamente proporcional ao crescimento bacteriano, o que facilita a visualização dos resultados.

\subsubsection{Determinação da atividade de proteínas relacionadas à patogênese em plantas de tomate}

As amostras vegetais consistiram de cinco folíolos, obtidos de folhas de tomate, coletadas a partir dos seguintes tratamentos: I) plantas tratadas com água; II) plantas tratadas com extrato aquoso de basidiocarpos do isolado ABL 99/28, a 10\% (v/v); III) plantas tratadas com ASM, a $50 \mathrm{ppm}$. Cada planta de tomate recebeu $10 \mathrm{~mL}$ de um dos tratamentos, quando apresentava cinco a seis folhas. Os tempos de amostragem foram aos 3, 6 e 9 dias após os tratamentos. As amostras foram homogeneizadas em 4,0 mL de tampão fosfato $10 \mathrm{mM}$ (pH 6,0) (tampão de extração), contendo $0,5 \%$ polivinil pirrolidona (PVP), e centrifugadas a $20.000 \mathrm{~g}\left(30 \mathrm{~min}, 4{ }^{\circ} \mathrm{C}\right)$. Os sobrenadantes foram utilizados para se avaliar as atividades de peroxidases e glucanases, bem como o teor de proteínas totais.

A atividade de peroxidases nas amostras foi determinada espectrofotometricamente a $470 \mathrm{~nm}$ em uma mistura de reação que consistiu de $0,1 \mathrm{~mL}$ de extrato protéico e $2,9 \mathrm{~mL}$ de tampão de extração, este contendo guaiacol $0,25 \%(\mathrm{v} / \mathrm{v})$ e peróxido de hidrogênio $0,1 \mathrm{M}$. A reação foi permitida de proceder por $4 \mathrm{~min}$, com as medidas de densidade óptica tomadas a cada $20 \mathrm{~s}$, iniciando-se 1 min após a adição do extrato ao substrato. Os resultados foram expressos em unidades de Densidade Óptica a $470 \mathrm{~nm} / \mathrm{mg}$ proteína/ minuto (DO/mg prot/min).

A atividade de $\beta-1,3$ glucanases nas amostras foi determinada ela quantificação colorimétrica de açúcares redutores liberados a partir de laminarina (Vogelsang \& Barz, 1993). A reação envolveu $50 \mu \mathrm{L}$ do extrato protéico e $450 \mu \mathrm{L}$ de laminarina (1,5 $\mathrm{mg} / \mathrm{mL}$ ) em tampão acetato de sódio $0,1 \mathrm{M}\left(\mathrm{pH} \mathrm{5,0)}\right.$, a $44{ }^{\circ} \mathrm{C}$ durante $70 \mathrm{~min}$. Após o período de incubação, os açúcares formados na reação foram quantificados pelo método de Lever (1972), adicionando-se à reação $1,5 \mathrm{~mL}$ de solução de hidrazida do ácido $p$ hidroxibenzóico $1 \%$ em $\mathrm{NaOH}(\mathrm{HAPH})$. A mistura foi mantida em água em ebulição sob banho-maria por 5 min, resfriada, determinando-se então a absorbância a $410 \mathrm{~nm}$. 
Para cada amostra, descontou-se a absorbância obtida a partir da mistura, cujos reagentes foram adicionados na seguinte ordem: $50 \mu \mathrm{L}$ do respectivo extrato protéico + $1,5 \mathrm{~mL}$ de HAPH (inativação enzimática) $+450 \mu \mathrm{L}$ de laminarina $(1,5 \mathrm{mg} / \mathrm{mL})$, de modo que o resultado final expressasse apenas açúcares provenientes da ação das glucanases. Após a quantificação de proteínas das amostras, a atividade de glucanases foi expressa em $\mu \mathrm{Katal} / \mathrm{mg}$ proteína, onde 1 Katal é definido como a atividade enzimática catalisando a formação de 1 mol de equivalente-glicose/segundo.

As atividades de enzimas relacionadas à patogênese foram expressas em relação ao conteúdo total de proteínas das amostras, o qual foi determinado empregando-se o método de Bradford (1976). Para tal, adicionaram-se $200 \mu \mathrm{L}$ de reagente concentrado de Bradford a $800 \mu \mathrm{L}$ do extrato protéico. Após $10 \mathrm{~min}$, realizou-se a leitura de absorbância a $595 \mathrm{~nm}$. A concentração de proteínas de cada amostra foi expressa em $\mu \mathrm{g}$ de albumina de soro bovino (ASB), utilizando-se de curva padrão de concentrações de ASB variando de 0 a $20 \mu \mathrm{g} / \mathrm{mL}$.

\subsection{Resultados}

\subsubsection{Proteção de plantas de tomate contra $X$. vesicatoria}

De maneria geral, plantas inoculadas com suspensão bacteriana ajustada para 0,3 unidades de absorbância (U.A.) a $600 \mathrm{~nm}$ (equivalente a uma concentração bacteriana de $10^{8} \mathrm{ufc} / \mathrm{mL}$ ) não foram protegidas pelos extratos dos cogumelos.

Os resultados da Figura 1 mostram as cultivares IPA-5 (suscetível) e Agrocica45, que apresenta resistência de campo a $X$. vesicatoria, em experimento onde os extratos de basidiocarpos foram aplicados em concentração de até 15\% (v/v), $24 \mathrm{~h}$ antes da inoculação com a bactéria (U.A. = 0,3). Não houve efeito de doses dos extratos sobre a severidade da doença, pelo teste $\mathrm{F}$ a $5 \%$ de significância.

Aplicando-se os extratos aquosos de basidiocarpos de shiitake a 2 e $5 \%$ (v/v) na cultivar IPA-5, com intervalo de 2 dias entre aplicação-inoculação, também não foi observada redução significativa na bacteriose em dois experimentos independentes, onde a concentração bacteriana utilizada foi de 0,3 U.A. (Figura 2). 


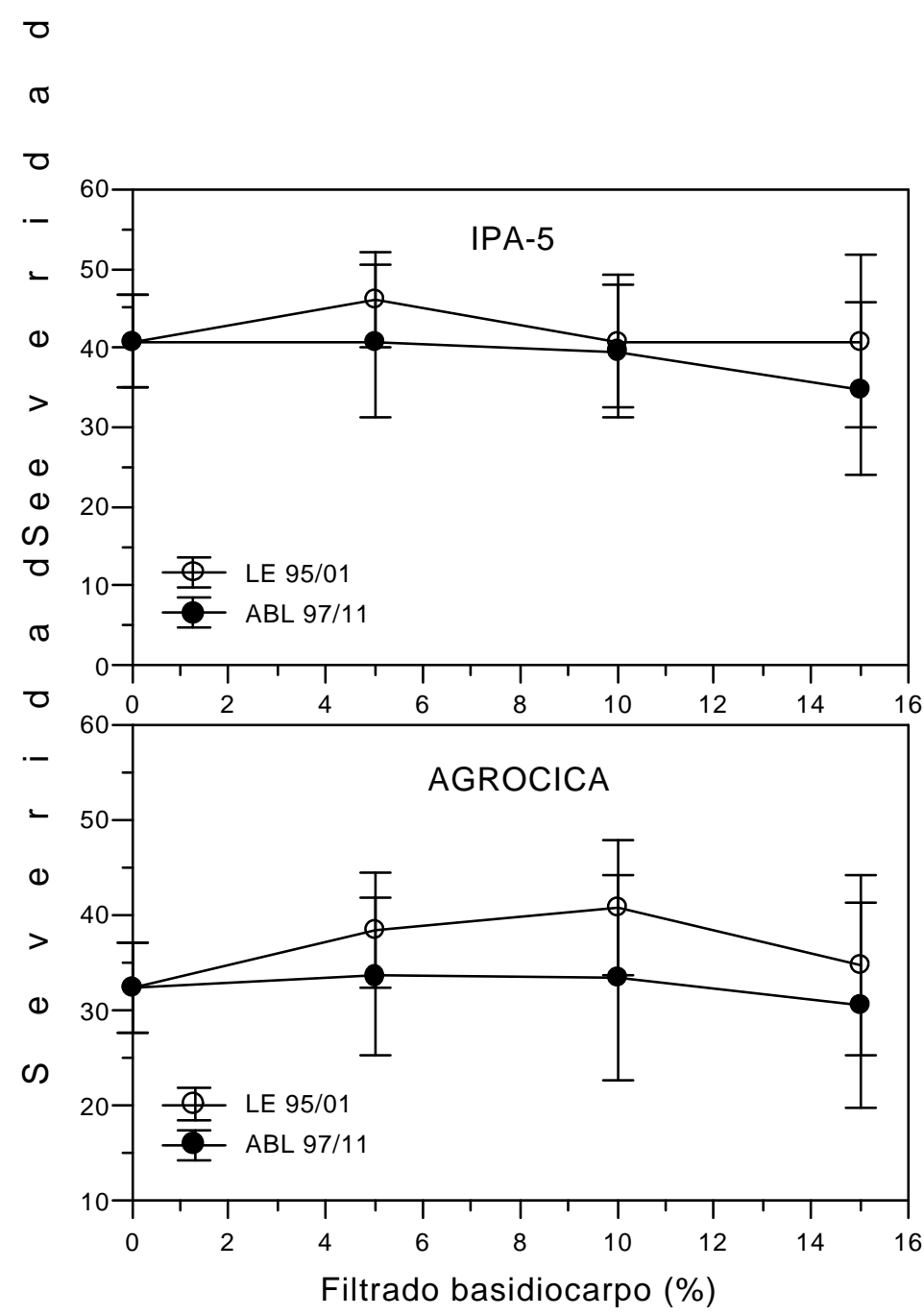

Figura 1 - Efeito dos extratos aquosos de basidiocarpos dos isolados LE 95/01 de Lentinula edodes e ABL 97/11 de Agaricus blazei na severidade da doença provocada por Xanthomonas vesicatoria (inóculo = 0,3 U. A. a $600 \mathrm{~nm}$ ) em duas cultivares de tomate. Tratamentos efetuados $24 \mathrm{~h}$ antes da inoculação das plantas. Barras representam a média \pm desvio padrão. Não houve efeito de doses pelo teste $\mathrm{F}$ a $5 \%$ de significância 
0
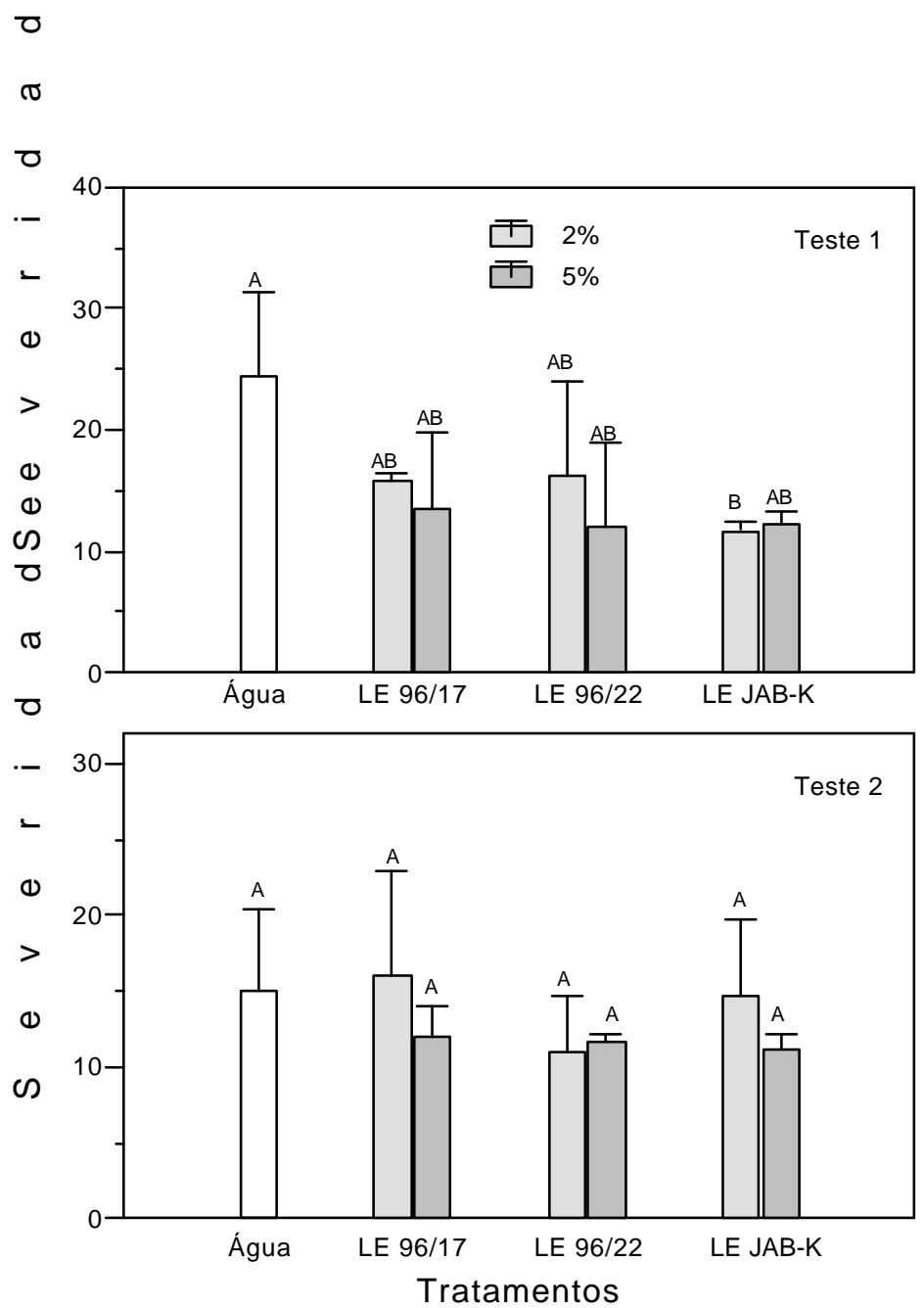

Figura 2 - Efeito dos extratos aquosos de basidiocarpos dos isolados LE 96/17, LE 96/22 e LE JAB-K de Lentinula edodes, utilizados a 2 e $5 \%(\mathrm{v} / \mathrm{v})$, sobre a severidade da doença provocada por Xanthomonas vesicatoria (inóculo $=0,3$ U. A. a 600 nm) em tomateiro (cultivar IPA-5), em dois experimentos independentes (Teste 1 e Teste 2). Tratamentos efetuados 2 dias antes da inoculação das plantas. Barras representam a média \pm desvio padrão. Médias seguidas pelas mesmas letras não diferem entre si pelo teste de Tukey a 5\%

Aumentando-se o intervalo de tempo entre aplicação-inoculação para 5 dias, e utilizando-se extratos de basidiocarpos a 10\% (v/v), a severidade da bacteriose foi reduzida por alguns isolados de L. edodes e de A. blazei, na dependência da 
concentração do inóculo bacteriano. Mantendo-se a concentração de X. vesicatoria em 0,3 U.A., os extratos continuaram não exercendo controle sobre a doença (Figura 3). No entanto, quando o inóculo bacteriano foi reduzido para 0,15 U.A., houve redução significativa na bacteriose em dois de três testes conduzidos com a cultivar IPA-5 (Tabela 1).

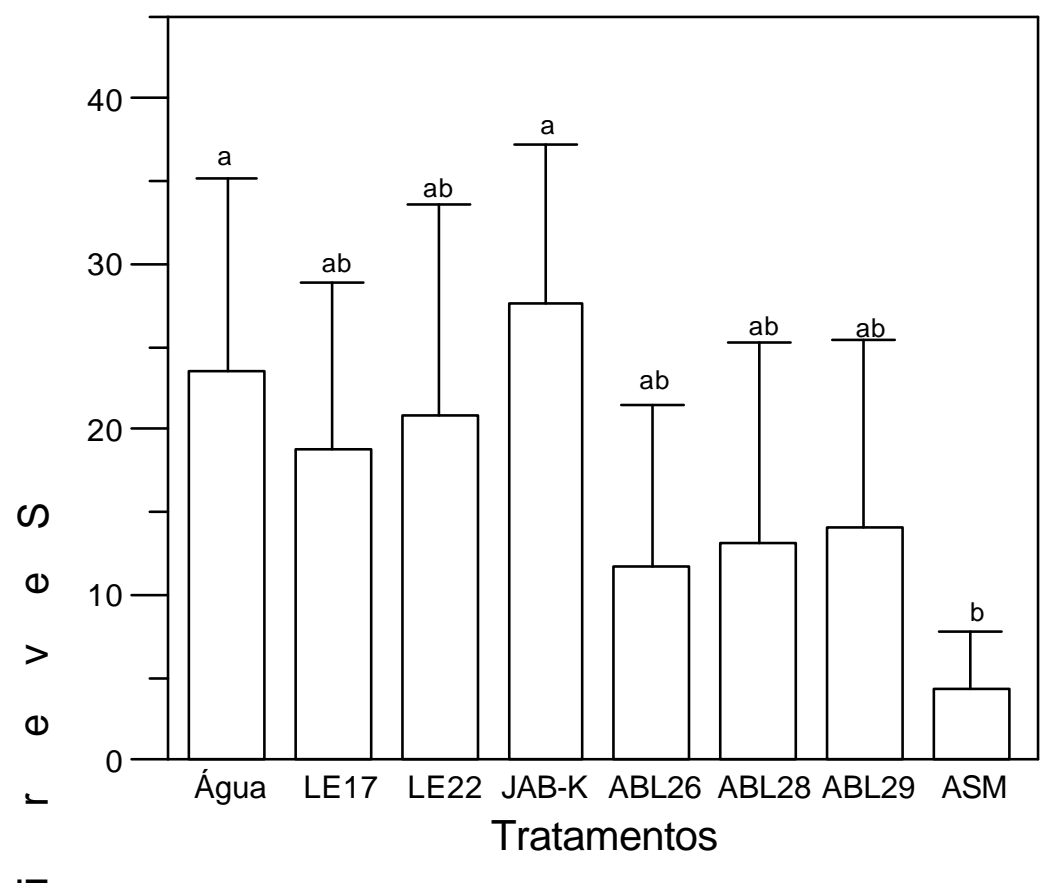

Figura 3 - Efeito dos extratos aquosos de basidiocarpos dos isolados LE 96/17, LE 96/22 e LE JAB-K de Lentinula edodes e dos isolados ABL 99/26, ABL 99/28 e ABL 99/29 de Agaricus blazei, utilizados a 10\% (v/v), sobre a severidade da doença provocada por Xanthomonas vesicatoria (inóculo =0,3 U. A. a 600 $\mathrm{nm}$ ) em tomateiro (cultivar IPA-5). ASM = ativador de plantas, utilizado a 50 ppm. Tratamentos efetuados 5 dias antes da inoculação das plantas. Barras representam a média \pm desvio padrão. Médias seguidas pelas mesmas letras não diferem entre si pelo teste de Tukey a $5 \%$ 
Tabela 1. Proteção de plantas de tomate contra Xanthomonas vesicatoria (inóculo $=0,15$ U.A.) pelo tratamento com extratos aquosos de basidiocarpos de Lentinula edodes (isolados LE 95/01, LE 96/22 e LE JAB-K) e de Agaricus blazei (isolados ABL 99/26 e ABL 99/28), utilizados a 10\% (v/v), em três experimentos realizados em diferentes épocas do ano. Intervalo entre tratamento-inoculação $=5$ dias. Os dados se referem à porcentagem de redução na bacteriose em relação ao controle (plantas tratadas com água)

\begin{tabular}{|c|c|c|c|c|}
\hline Isolado & $\begin{array}{c}1^{\mathrm{o}} \text { experimento } \\
\text { (Início Primavera) }\end{array}$ & $\begin{array}{l}2^{\circ} \text { experimento } \\
\text { (Final Primavera) }\end{array}$ & $\begin{array}{c}3^{\circ} \text { experimento } \\
\text { (Verão) }\end{array}$ & $\begin{array}{r}\text { Proteção } \\
\text { Média }^{1}\end{array}$ \\
\hline LE 95/01 & $36 \%$ n.s. & n. t. & 0 & $18 \%$ \\
\hline LE 96/22 & $27 \%$ n.s. & $70 \% *$ & $34 \%$ n.s. & $43 \%$ \\
\hline LE JAB-K & $0 \%$ n.s & $65 \% *$ & n.t. & $32 \%$ \\
\hline ABL 99/26 & $0 \%$ n.s. & n.t. & $41 \%$ n.s. & $20 \%$ \\
\hline ABL 99/28 & $25 \%$ n.s. & $58 \% *$ & $51 \% *$ & $45 \%$ \\
\hline $\mathrm{ASM}^{2}$ & $82 \% *$ & $85 \% *$ & $88 \% *$ & $85 \%$ \\
\hline \multicolumn{5}{|c|}{$\begin{array}{l}{ }^{1} \text { Média da proteção conferida pelos isolados dos cogumelos em três exper } \\
\text { relação à severidade da bacteriose em plantas tratadas com água e, } 5 \\
\text { inoculadas com } X \text {. vesicatoria ( } 0,15 \text { U.A.) }\end{array}$} \\
\hline \multicolumn{5}{|c|}{${ }^{2}$ Acibenzolar-S-metil, ativador de plantas, utilizado a 50 ppm (controle positivo) } \\
\hline \multicolumn{5}{|c|}{ n.s. = proteção não significativa pelo teste de Tukey a 5\% } \\
\hline *proteção sig & icativa com base & teste de Tukey a $5 \%$ & & \\
\hline
\end{tabular}

\subsubsection{Efeito in vitro de L. edodes e A. blazei sobre X. vesicatoria}

Os isolados LE 95/01 e LE 96/22 de L. edodes, utilizados a 10\% (v/v), não apresentaram efeito in vitro sobre a bactéria, quando esta foi empregada nas concentrações de 0,15 ou 0,05 U.A., enquanto os isolados ABL 97/11 e principalmente ABL 99/28 estimularam o crescimento bacteriano em ambas as concentrações de $X$. 
vesicatoria. Por outro lado, o desenvolvimento da bactéria foi inibido pelo ativador de plantas, acibenzolar-S-metil, mas apenas na menor concentração bacteriana (Figura 4).

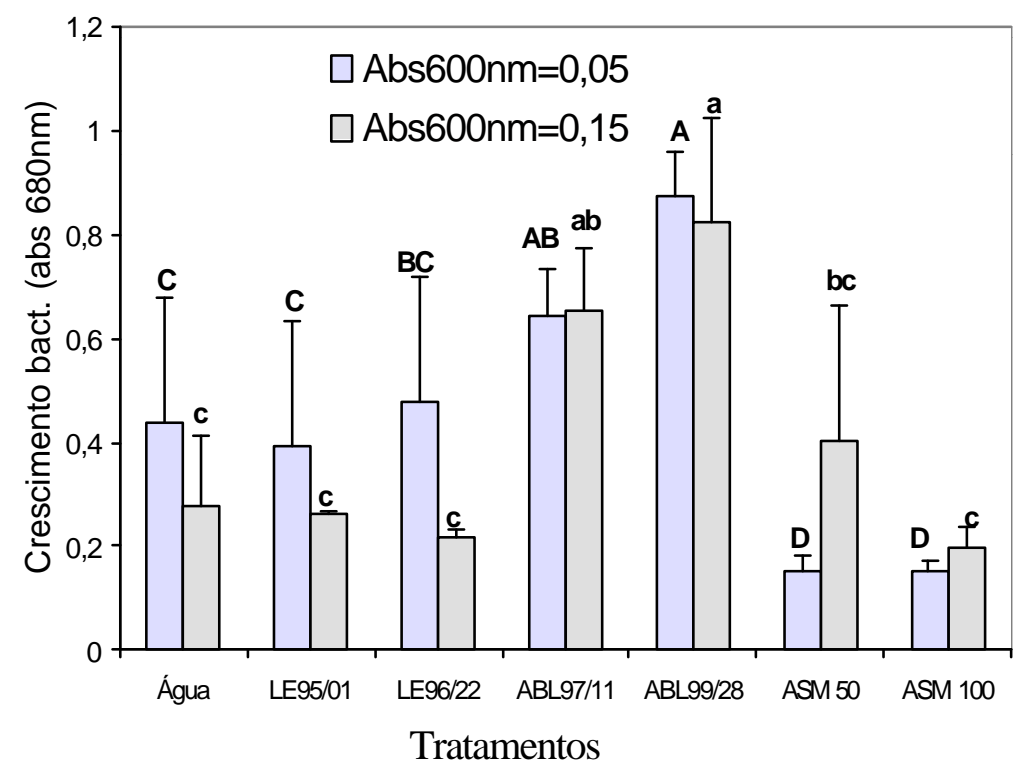

Figura 4 - Efeito dos extratos aquosos de basidiocarpos dos isolados LE 95/01 e LE 96/22 de Lentinula edodes e ABL 97/11 e ABL 99/28 de Agaricus blazei, utilizados a $10 \%(\mathrm{v} / \mathrm{v})$, sobre o desenvolvimento in vitro de Xanthomonas vesicatoria, utilizada nas concentração de 0,15 e 0,05 U.A. a 600 nm. ASM $50 / 100$ = acibenzolar S-metil, utilizado a 50 ou 100 ppm, respectivamente. As barras representam a média \pm desvio padrão. Médias seguidas pelas mesmas letras não diferem entre si pelo teste de Tukey a 5\%

Outro teste foi realizado, no qual a concentração bacteriana foi ajustada para 0,015 U.A. O isolado LE 95/01 continuou sem afetar a bactéria até a concentração de $10 \%$ de extrato, no entanto, a partir de $15 \%$ (v/v), a inibição no crescimento bacteriano foi total. O isolado LE 96/22 estimulou significativamente o desenvolvimento da bactéria já a 5\% de extrato, enquanto os isolados de A. blazei, ABL 97/11 e ABL 99/28 não afetaram o crescimento bacteriano, nesse ensaio (Figura 5). 


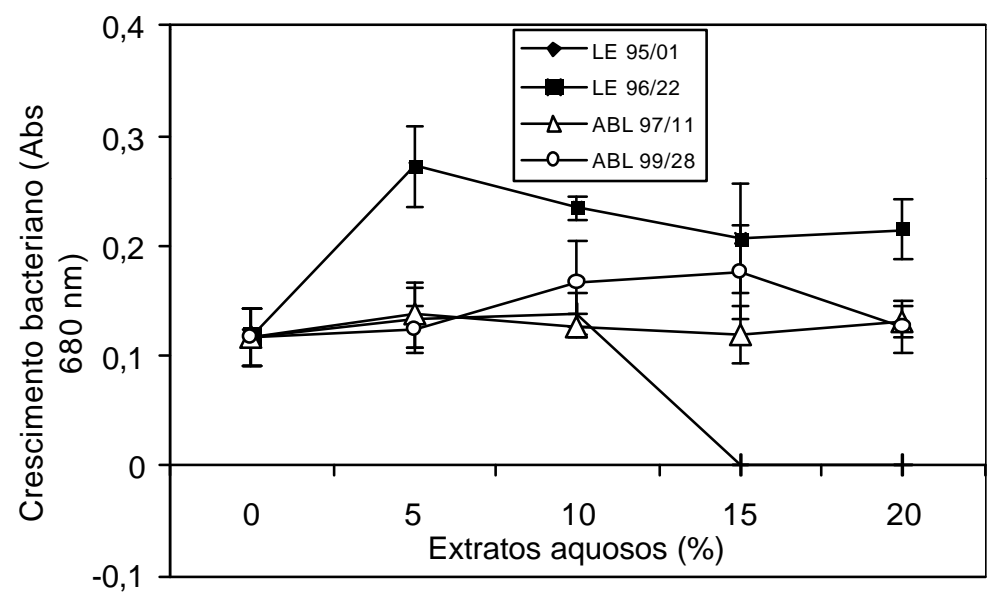

Figura 5 - Efeito dos extratos aquosos de basidiocarpos dos isolados LE 95/01 e LE 96/22 de Lentinula edodes e ABL 97/11 e ABL 99/28 de Agaricus blazei sobre o desenvolvimento in vitro de Xanthomonas vesicatoria, utilizada na concentração de 0,015 U.A. a $600 \mathrm{~nm}$. Efeito significativo de doses de extratos foi encontrado para os isolados LE 95/01 e LE 96/22, através do teste $\mathrm{F}$, a $5 \%$ de significância

\subsubsection{Determinação da atividade de proteínas relacionadas à patogênese em plantas de tomate}

No experimento conduzido para se avaliar o nível de peroxidases, ocorreu um aumento na atividade das mesmas em plantas de tomate tratadas com extratos do isolado ABL 99/28, mas apenas no $3^{\circ}$ dia após os tratamentos. O ativador de plantas ASM, utilizado em concentração na qual reduziu em mais de $80 \%$ a severidade da bacteriose, não teve efeito siginificativo na atividade de peroxidases (Figura 6).

Quanto ao ensaio envolvendo glucanases, tanto ABL 99/28 como ASM provocaram elevação na atividade enzimática. O extrato de basidiocarpos do isolado ABL 99/28 de A. blazei proporcionou uma elevação na atividade de glucanases em tomateiro mais rápida do que a provocada por ASM, com atividade máxima no $3^{\circ}$ dia após o tratamento, a qual foi levemente reduzida no decorrer do tempo. Por outro lado, o pico da atividade de glucanases nas plantas tratadas com o ASM ocorreu somente no 6 
dia, mas representou uma atividade maior que a dos outros tratamentos. A inoculação com $X$. vesicatoria, independente do tratamento prévio, causou um leve aumento na atividade enzimática (Figura 7).

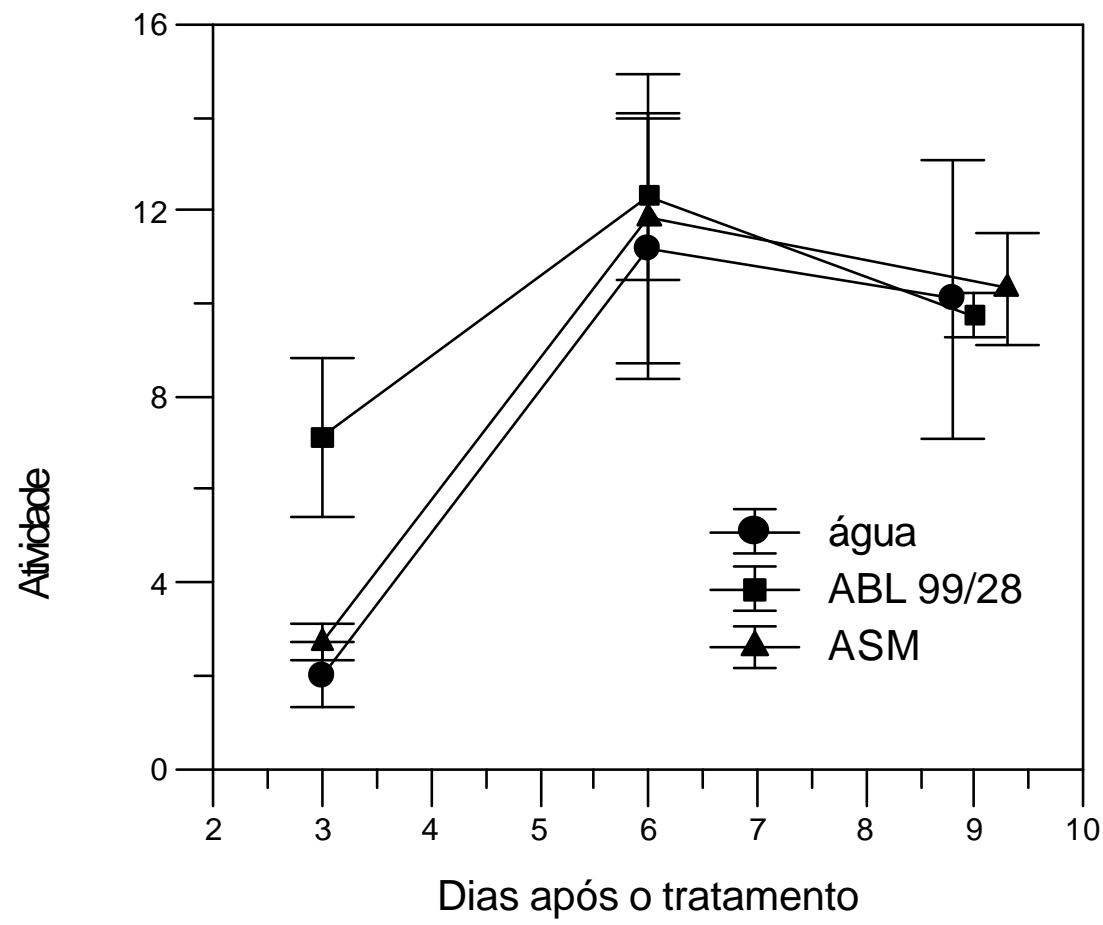

Figura 6 - Atividade de peroxidases em folhas de tomateiro coletadas a partir de plantas tratadas com água, com extrato aquoso de basidiocarpos de Agaricus blazei a $10 \%$ (isolado ABL 99/28) ou com acibenzolar-S-metil (ASM) a 50 ppm 


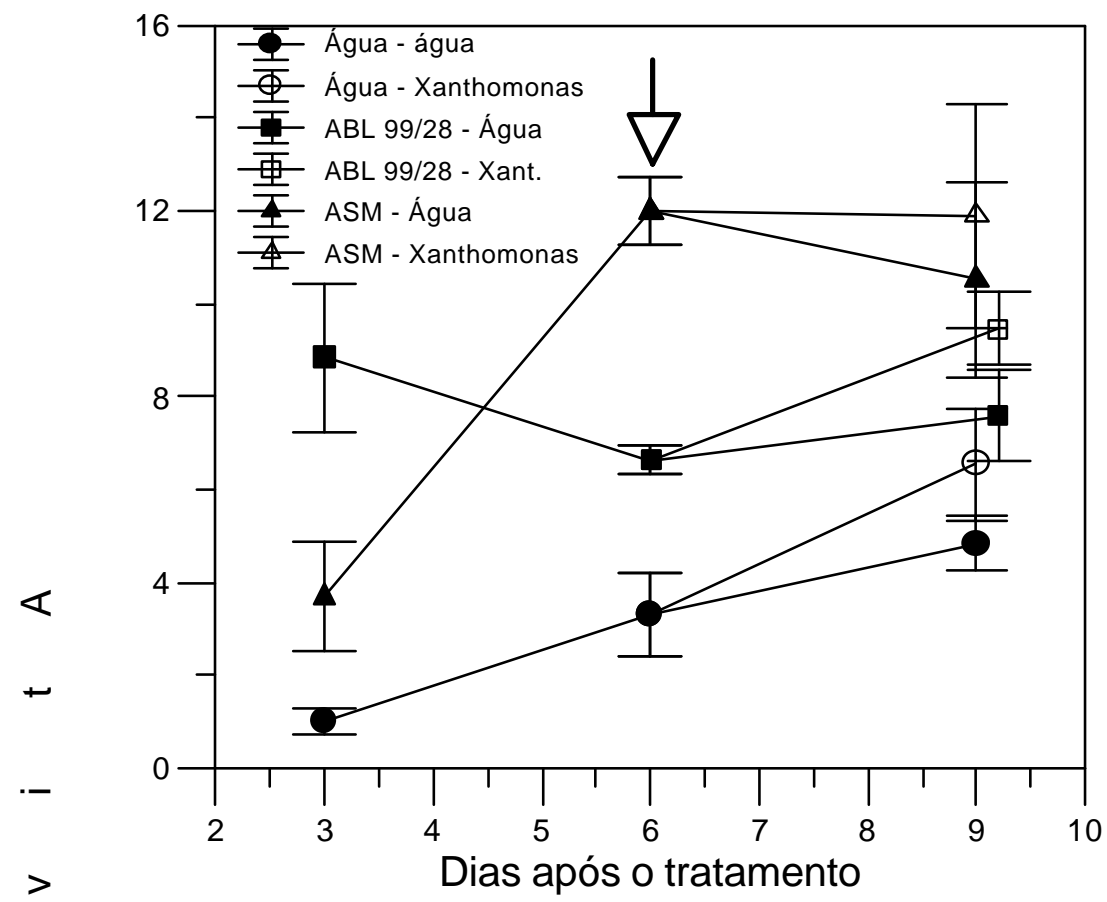

Figura 7 - AAtividade de glucanases em folhas de tomateiro coletadas a partir de plantas đatadas com água, com extrato aquoso de basidiocarpos de Agaricus blazei a dర% (isolado ABL 99/28) ou com acibenzolar-S-metil (ASM) a 50 ppm. A seta indica o momento da inoculação das plantas com Xanthomonas vesicatoria, que foi realizada após a coleta foliar relativa ao $6^{\circ}$ dia

()

\subsection{Discussão}

L. edodes, o cogumelo shiitake, vem sendo utilizado há muito tempo em pesquisas visando o controle de moléstias em animais, devido às suas propriedades imunológicas e antibióticas. Na Fitopatologia, o trabalho de Pacumbaba et al. (1999) é um dos poucos mostrando que lixiviados dotidos a partir do cogumelo inibiram in vitro várias bactérias causadoras de doenças em plantas, bem como protegeram tomate e feijão-lima contra doenças bacterianas. Entretanto, o presente trabalho mostrou que a antibiose proporcionada pelo isolado LE 01 de L. edodes contra X. vesicatoria só 
ocorreu em uma concentração bacteriana 10 vezes inferior à utilizada in vivo, explicando de certo modo, o insucesso no controle da doença.

Um outro isolado de shiitake, o LE 96/22, bem como os isolados ABL 97/11 e ABL 99/28 de A. blazei estimularam o crescimento bacteriano in vitro, mostrando que, nestas situações, o aspecto nutricional dos extratos de basidiocarpos superou qualquer composto antibiótico que pudesse estar presente nos mesmos.

Interessantes foram os resultados encontrados com o isolado ABL 99/28 de A. blazei. Esse isolado não exerceu qualquer efeito inibitório sobre a bactéria in vitro, chegando até a estimular o seu crescimento. Isso aconteceu quando o extrato do cogumelo foi utilizado a $10 \%(\mathrm{v} / \mathrm{v})$ e a concentração bacteriana foi de 0,15 U.A., os mesmos parâmetros utilizados em três testes in vivo, em dois dos quais o isolado $\mathrm{ABL}$ 99/28 reduziu significativamente a severidade da doença bacteriana. O intervalo de tempo entre o tratamento com extrato de ABL 99/28 e a inoculação das plantas, nesses testes, foi 5 dias, sugerindo a necessidade de um tempo para ativar os mecanismos de defesa do tomateiro.

O ativador de plantas ASM, utilizado nos experimentos de tomate como um controle positivo, também não exibiu efeito in vitro sobre $X$. vesicatoria quando a bactéria foi empregada na concentração utilizada para inocular as plantas (0,15 U.A.).

As análises bioquímicas realizadas a partir de folhas de tomate mostraram que as peroxidases não são bons marcadores de resistência para o patossistema em questão, já que não houve diferenças no acúmulo dessas enzimas entre plantas tratadas com ASM, indutor de resistência altamente eficiente no controle da bacteriose, e plantas tratadas com água. No caso das glucanases, o ASM provocou elevação da atividade enzimática em tomateiro, enquanto o acúmulo proporcionado por ABL 99/28 foi de menor intensidade, demonstrando-se haver uma relação entre a atividade de glucanases no decorrer do tempo e a proteção das plantas. Esse experimento revelou que o isolado ABL 99/28 modificou o metabolismo do tomateiro relacionado à defesa, indicando que as glucanases poderiam ter um papel na resistência contra a bacteriose.

$\mathrm{Na}$ proteção de tomate contra $P$. infestans, Anfoka \& Buchenauer (1997) obtiveram resultados opostos ao do presente trabalho, mostrando que a atividade de 
peroxidases, mas não a de glucanases, teve correlação com a resistência induzida pelo TNV.

A participação de glucanases como um dos mecanismos de proteção de tomateiro foi demostrada por Joosten \& De Wit (1989), Tamietti et al. (1993), Cohen et al. (1994) e Lawrance et al. (1996) contra Cladosporium fulvum, Fusarium oxysporum f. sp. lycopersici, Phytophthora infestans e Alternaria solani, respectivamente. A conclusão a respeito do papel das glucanases nesses estudos foi baseada no maior nível dessas enzimas presentes constitutivamente em genótipos de tomateiro resistentes em relação aos suscetíveis (Joosten \& De Wit, 1989; Lawrance et al., 1996) ou no acúmulo de glucanases após o tratamento com indutores de resistência, tais como linhagens nãopatogênicas de Fusarium (Tamietti et al., 1993) e o aminoácido não-protéico DL-3amino-n-ácido butanóico (Cohen et al., 1994).

Nos estudos comentados, a ação das glucanases pode ter sido dretamente sobre os fungos fitopatogênicos, os quais apresentam glucana na constituição de suas paredes celulares. Além disso, os fragmentos liberados pela lise da parede celular poderiam funcionar como elicitores de outras respostas de defesa. No caso da proteção contra $X$. vesicatoria, a importância das glucanases sintetizadas pelas plantas de tomate após o estímulo por ASM e ABL 99/28 permanece não esclarecida. Essas enzimas podem não ter efeito direto contra a bactéria, mas contribuir para a criação de um ambiente desfavorável ao patógeno, nos espaços intercelulares, onde ocorre a colonização da planta por $X$. vesicatoria.

Além de depender do intervalo de tempo entre tratamento-inoculação e da concentração de inóculo bacteriano, a proteção conferida por ABL 99/28 contra $X$. vesicatoria foi dependente das condições ambientais, tendo sido obtido controle da doença em um experimento conduzido no final da primavera e em um outro no verão, enquanto que o teste realizado no início da primavera não propiciou redução na severidade da doença (Tabela 1).

A ausência de efeito negativo sobre a bactéria, a ativação de uma proteína relacionada à patogênese e a dependência do ambiente sugerem que o extrato aquoso de 
ABL 99/28 reduziu a severidade da bacteriose atuando sobre a planta através da resistência induzida.

\subsection{Conclusões}

O extrato aquoso de basidiocarpos do isolado ABL 99/28 de A. blazei apresentou potencial para o controle da bacteriose do tomateiro provocada por X. vesicatoria. Por outro lado, os isolados de L. edodes testados mostraram-se ineficientes no referido patossistema. 


\section{CONCLUSÕES GERAIS}

Os extratos aquosos de basidiocarpos dos cogumelos Lentinula edodes e Agaricus blazei apresentam susbstâncias elicitoras de respostas de defesa em plantas e podem auxiliar no controle de doenças vegetais, por meio da indução de resistência, dependendo da concentração de extrato utilizada e da natureza do agente causal. 


\section{REFERÊNCIAS BIBLIOGRÁFICAS}

ADAM, A.L.; PIKE, S.; HOYOS, M.E.; STONE, J.M.; WALKER, J.C.; NOVACKY, A. Rapid and transient activation of a myelin basic protein kinase in tobacco leaves treated with harpin from Erwinia amylovora. Plant Physiology, v.115, n.2, p.853$861,1997$.

ADASKAVEG, J.E.; HINE, R.B. Copper tolerance and zinc sensivity of mexican strains of Xanthomonas campestris pv. vesicatoria, causal agent of bacterial spot of pepper. Plant Disease, v.69, n.11, p.993-996, 1985.

ALBERT, R.; ANDERSON, A.J. The effect of Pseudomonas putida colonization on root surface peroxidase. Plant Physiology, v.85, n.2, p.537-541, 1987.

ALEXANDER, D.; GOODMAN, R.M.; GUTRELlA, M.; GLASCOCK, C.; WEYNANN, K.; FRIEDRICH, L.; MADDOX, D.; AHLGOY, P.; LUNTZ, T.; WARD, E.; RYALS, J. Increased tolerance to oomycete pathogens in transgenic tobacco expressing pathogenesis-related protein-1a. Proceedings of the National Academy of Science of the USA, v.90, n.15, p.7327-7331, 1993.

ANFOKA, G. H. Benzo-(1,2,3)-thiadiazole-7-carbothioic acid S-methyl ester induces systemic resistance in tomato to Cucumber mosaic virus. Crop Protection, v.19, n.6, p.401-405, 2000. 
ANFOKA, G.; BUCHENAUER, H. Systemic acquired resistance in tomato against Phytophthora infestans by pre-inoculation with tobacco necrosis virus. Physiological and Mole cular Plant Pathology, v.50, n.2, p.85-101, 1997.

AYERS, A.R.; EBEL, J.; VALENT, B.; ALBERSHEIM, P. Host-pathogen interactions. $X$ - Fractionation and biological activity of an elicitor isolated from the mycelial walls of Phytophthora megasperma var sojae. Plant Physiology, v.57, n.5, p.760765,1976 a.

AYERS, A.R.; EBEL, J.; FINELlI, F.; BERGER, N.; ALBERSHEIM, P. Hostpathogen interactions. IX - Quantitative assays of elicitor activity and characterization of the elicitor present in the extracellular medium of cultures of Phytophthora megasperma var sojae. Plant Physiology, v.57, n.5, p.751-759, 1976b.

BAKER, C.J.; ORLANDI, E.W. Active oxygen in plant pathogenesis. Annual Review of Phytopathology, v.33, p.299-321, 1995.

BALDWIN, I. T. Jasmonate-induced responses are costly but benefit plants under attack in native populations. Proceedings of the National Academy of Science of the USA, v.95, n.14, p.8113-8118, 1998.

BASHAN, Y. Inhibition of seed germination and root development caused by Xanthomonas campestris pv. vesicatoria in pepper and tomato. Journal of Phytopathology, v.116, n.3, p.228-237, 1986.

BEDNARZ, C.W.; BROWN, S.N.; FLANDERS, J.T.; TANKERSLEY, T.B.; BROWN, S.M. Effects of foliar applied harpin protein on cotton lint yield, fiber quality, and crop maturity. Communications in Soil Science and Plant Analysis, v.33, n.5/6, p.933-945, 2002. 
BEISSMANN, B.; REISENER, H.J. Isolation and purity determination of a glycoprotein elicitor from wheat stem rust by medium-pressure liquid chromatography. Journal of Chromatography, v.521, n.2, p.187-197, 1990.

BENHAMOU, N.; BELANGER, R. Benzothiazole-mediated induced resistance to Fusarium oxysporum f. sp. radicis-lycopersici in tomato. Plant Physiology, v.118, n.4, p.1203-1212, 1998.

BENHAMOU, N.; BELANGER, R.R.; PAULITZ, T.C. Induction of differential host responses by Pseudomonas fluorescens in Ri T-DNA-transformed pea roots after challenge with Fusarium oxysporum f. sp. pisi and Pythium ultimum. Phytopathology, v.86, n.11, p.1174-1185, 1996.

BERGSTROM, G.C.; JOHNSON, M.C.; KUC, J. Effects of local infection of cucumber by Colletotrichum lagenarium, Pseudomonas lachrymans, or Tobacco necrosis virus on systemic resistance to Cucumber mosaic virus. Phytopathology, v.72, n.7, p.922-926, 1982.

BHASKARA, R.M.V.; ARUL, J.; ANGERS, P.; COUTURE, L. Chitosan treatment of wheat seeds induces resistance to Fusarium graminearum and improves seed quality. Journal of Agricultural and Food Chemistry, v.47, n.3, p.1208-1216, 1999.

BIANCO, C. Basidiomycetes in relation to antibiosis. II. Antibiotic activity of mycelia and culture liquids. Bacterial and Viral Immunology, v.75, p.267-274, 1981.

BINDER, A.; BAER, G.; HOFMANN, C.; KOVATS, K. Mechanisms in systemic induced disease resistance. In: LUGTENBERG, B.J.J. (Ed.). Sinal molecules in plants and plant-microbe interactions. Berlin: Springer-Verlag, 1989. p.267-272. 
BLANCARD, D.; LECOQ, H.; PITRAT, M. Enfermedades de las cucurbitáceas: observar, identificar, luchar. Madrid: Ed. Mundi-Prensa, 1996. 301p.

BOLLER, T. Ethylene and plant-pathogen interactions. Current Topics in Plant Physiology, v.5, p.138-145, 1990.

BOUZAR, H.; JONES, J.B.; STALL, R.E.; HODGE, N.C.; MINSAGAVE, G.V.; BENEDICT, A.A.; ALVAREZ, A.M. Physiological, chemical, serological, and pathogenic analyses of a worldwide collection of Xanthomonas campestris pv. vesicatoria strains. Phytopathology, v.84, n.7, p.663-671, 1994.

BOUZAR, H.; JONES, J.B.; STALL, R.E.; LOUWS, M.S.; SCHNEIDER, M.; RADEMAKER, J.L.W.; BRUIJN, F.J.; JACKSON, L.E. Multiphasic analysis of xanthomonads causing bacterial spot disease on tomato and pepper in the Caribbean and Central America: evidence for common lineages within and between countries. Phytopathology, v.89, n.4, p.328-335, 1999.

BRADFORD, M.A. A rapid and sensitive method for the quantitation of microgram quanties of protein utilizing the principle of protein-dye binding. Analytical Biochemistry, v.72, n.1/2, p.248-254, 1976.

BRADLEY, D.J.; KJELLBOM, P.; LAMB, C.J. Elicitor-induced and wound-induce oxidative cross-linking of a proline-rich plant cell wall portein - a novel, rapid defense response. Cell, v.70, n.1, p.21-30, 1992.

BRAGA, G.C.; EIRA, A.F.; CELSO, P.G.; COLAUTO, N.B. Manual do cultivo de Agaricus blazei “Cogumelo-do-sol”. Botucatu: Fundação de Estudos e Pesquisas Agrícolas e Florestais, 1998. 44p. 
BREENE, W.M. Nutritional and medicinal value of specialty mushrooms. Journal of Food Protection, v.53, n.10, p.883-894, 1990.

BROGLIE, K.; CHET, I.; HOLLIDAY, M.; CRESSMAN, R.; BIDDLE, P.; KNOWLTONS, S.; MAUVAIS, C.J.; BROGLIE, R. Transgenic plants with enhanced resistance to the fungal pathogen Rhizoctonia solani. Science, v.254, n.5035, p.1194-1197, 1991.

CARUSO, F.L.; KUC, J. Induced systemic resistance of cucumber to anthracnose and angular leaf spot by Pseudomonas lachrymans and Colletotrichum lagenarium. Physiological Plant Pathology, v.14, n.2, p.191-201, 1979.

CHANG, C.A. Characterization and comparison of Passionfruit mottle virus, a newly recognized potyvirus, with Passionfruit woodiness virus. Phytopathology, v.82, n.11, p.1358-1363, 1992.

CHEONG, J.J.; BIRBERG, W.; FUGEDI, P.; PILLOTI, A.; GAREGG, P.J.; HONG, N.; OGAWA, T.; HAHN, M.G. Structure activity relationships of oligo-beta-glucoside elicitors of phytoalexin accumulation in soybean. Plant Cell, v.3, n.2, p.127-136, 1991.

CHIHARA, G. Medical aspects of lentinan isolated from Lentinus edodes. In: CHANG, S.T.; BUSWELL, J.A.; CHIU, S.W. (Ed.). Mushroom biology and mushroom products. Hong Kong: The Chinese University Press, 1993. p.261-266.

CHIHARA, G.; MAEDA, Y.; HAMURO, J.; SASAKI, T.; FUKUOKA, W. Inhibition of mouse sarcoma 180 by polyssacharides from Lentinula edodes. Nature, v.222, p.687-688, 1969. 
COHEN, Y.; NIDERMAN, T.; MOSINGER, E.; FLUHR, R. $\beta$-aminobutyric acid induces the accumulation of pathogenesis-related proteins in tomato plants and resistance to late blight infection caused by Phytophthora infestans. Plant Physiology, v.104, n.1, p.59-66, 1994.

COLAUTO, N.B.; DIAS, E.S.; GIMENES, M.A.; EIRA, A.F. Genetic characterization of isolates of the basidiomycete Agaricus blazei by RAPD. Brazilian Journal of Microbiology, v.22, n.2, p.131-133, 2002.

CONTI, G.; BASSI, M.; CARMINUCCI, D.; GATTI, L.; BOCCI, A.M. Preinoculation with Tobacco necrosis virus enhances peroxidase activity and lignification in cucumber as a resistance response to Sphaerotheca fuliginea. Journal of Phytopathology, v.128, n.3, p.191-202, 1990.

CONTI, G.C.; BASSI, M.; MAFFI, D.; VIOLINI, G.; MAGNANI, L.; GATTI, L. Induced systemic resistance against Sphaerotheca fuliginea in cucumber: efficiency of Tobacco necrosis virus and copper sulphate in eliciting defence reactions. Journal of Phytopathology, v.140, n.2, p.123-132, 1994.

CORDIER, C.; POZO, M.J.; BAREA, J.M.; GIANINAZZI, S.; GIANINAZZIPEARSON, V. Cell defense responses associated with localized and systemic resistance to Phytophthora parasitica induced in tomato by an arbuscular mycorrhizal fungus. Molecular Plant-Microbe Interactions, v.11, n.10, p.10171028, 1998.

DALISAY, R.F.; KUC, J.A. Persistence of induced resistance and enhanced peroxidase and chitinase activities in cucumber plants. Physiological and Molecular Plant Pathology, v.47, n.5, p.315-328, 1995. 
DAVIS, K.R.; AUSUBEL, F.M. Characterization of elicitor-induced defense responses in suspension-cultured cells of Arabidopsis. Molecular Plant-Microbe Interactions, v.2, n.6, p.363-368, 1989.

DEAN, R.A.; KUC, J. Induced systemic protection in cucumber: effects of inoculum density on symptom development caused by Colletotrichum lagenarium in previously infected and uninfected plants. Phytopathology, v.76, n.2, p.186-189, 1986.

DEAN, R.A.; KUC, J. Rapid lignification in response to wouding and infection as a mechanism for induced systemic protection in cucumber. Physiological and Molecular Plant Pathology, v.31, n. 1, p.69-81, 1987.

DEHNE, H.W.; SCHÖNBECK, F. Untersuchungen uber den einfluss der endotrophen mycorrhiza auf die Fusarium-Welke der tomate. Pflkrankheiten v.10, n.75, p.630$632,1975$.

DE MEYER, G.; HOFTE, M. Salycilic acid produced by rhizobacterium Pseudomonas aeruginosa 7NSK-2 induces resistance to leaf infection by Botrytis cinerea on bean. Phytopathology, v.87, n.6, p.588-593, 1997.

DINANT, S.; BLAISE, F.; KUSIAK, C.; ASTIER-MANIFACIER, S.; ALBOUY, J. Heterologous resistance to potato virus $\mathrm{Y}$ in transgenic tobacco plants expressing the coat protein gene of lettuce mosaic potyvirus. Phytopathology, v.83, n.8, p.818824, 1993.

DI PIERO, R. M.; PASCHOLATI, S. F.; REZENDE, J. A. M. Efeito das cianobactérias Synechococcus leopoliensis e Nostoc sp. na infectividade do vírus do mosaico do fumo (TMV). Summa Phytopathologica, v.26, n.2, p.215-220, 2000. 
DOARES, S.H.; NARVAEZ-VASQUEZ, J.; CONCONI, A.; RYAN, C.A. Salicylic acid inhibits synthesis of proteinase inhibitors in tomato leaves induced by systemin and jasmonic acid. Plant Physiology, v.108, n.4, p.1741-1746, 1995.

DONG, H.; DELANEY, T.P.; BAUER, D.W.; BEER, S.V. Harpin induces disease resistance in Arabidopsis through the systemic acquired resistance pathway mediated by salicylic acid and NIM1 gene. Plant Journal, v.20, n.2, p.207-215, 1999.

DUVAL, A.M.Q. Diversidade de Xanthomonas spp. associadas a mancha bacteriana em tomateiro para processamento industrial no Brasil. Piracicaba, 2003. 111p. Tese (Doutorado) - Escola Superior de Agricultura "Luiz de Queiroz", Universidade de São Paulo.

EGUCHI, F.; WATANABE, Y.; KIKUKAWA, T.; YOSHIMOTO, H.; ABE, C.; HIGAKI, M. Renoprotetive effects of a hot water extract of Agaricus blazei fruiting bodies in experimental renal injury assessed by a DOCA- $\mathrm{NaCl}$ heminephrectomized rats. Journal of Tradicional Medicines, v.16, n.1, p.24-31, 1999.

EIRA, A.F.; MONTINI, R.M.C. Manual teórico-prático de cultivo do cogumelo shiitake. Botucatu: Fundação de estudos de pesquisas agrícolas e florestais, 1997. 115p.

FARINELLI, L.; MALNOË, P. Coat protein gene-mediated resistance to potato virus Y in tobacco examination of the resistance mechanisms - is the transgenic coat protein required for protection? Molecular Plant-Microbe Interactions, v.6, n.3, p.284 292, 1993. 
FNP CONSULTORIA \& COMÉRCIO. Agrianual 2002: anuário da agricultura brasileira. São Paulo, 2002. 536p.

FRIEDRICH, L.; LAWTON, K.; RUESS, W.; MASNER, P.; SPECKER, M.; GUTRELlA, M.; MEIER, B.; DRINCHER, S.; STAUB, T.; UKNESS, S.; METRAUX, J.P.; KESSMANN, H.; RYALS, J. A benzothiadiazole derivative induces systemic acquired resistance in tobacco. Plant Journal, v.10, n.1, p.61-70, 1996.

GAFFNEY, T.; FRIEDRICH, L.; VERNOOJ, B.; NEGROTTO, D.; NYE, G.; UKNESS, S.; WARD, E.; KESSMANN, H.; RYALS, J. Requirement of salicylic acid for the induction of systemic acquired resistance. Science, v.261, n.5122, p.754-756, 1993.

GESSLER, C.; KUC, J. Induction of resistance to Fusarium wilt in cucumber by root and foliar pathogens. Phytopathology, v.72, n.11, p.1439-1441, 1982.

GIORIA, R.; BOSQUÊ, G.G.; REZENDE, J.A.M.; AMORIM, L.; KITAJIMA, E.W. Incidência de viroses de maracujazeiro na Alta Paulista-SP e danos causados pelo Passion fruit woodiness virus. Fitopatologia Brasileira, v.25, p.182-189, 2000.

GOODE, M.J.; SASSER, M. Prevention, the key to controlling bacterial spot and bacterial speck of tomato. Plant Disease, v.64, p.831-834, 1980.

GOTTSTEIN, H.; KUC, J. Induction of systemic resistance to anthracnose in cucumber by phosphates. Phytopathology, v.79, n.2, p.176-179, 1989.

GROHMANN, A.A.; MUSUMECI, M. An inhibitor of tobacco mosaic virus produced by Aspergillus flavus. Arquivos do Instituto Biológico, v.39, p.69-73, 1972. 
GROSSKOPF, D.G.; FELIX, G.; BOLLER, T. A yeast-derived glycopeptide elicitor and chitosan or digitonin differentially induce ethylene biosynthesis, phenylalanine ammonia-lyase and callose formation in suspension-cultured tomato cells. Journal of Plant Physiology, v.138, n.6, p.741-746, 1991.

GUEDES, M.E.M.; RICHMOND, S.; KUC, J. Induced systemic resistance to anthracnose in cucumber as influenced by the location of the inducer inoculation with Colletotrichum lagenarium and the onset of flowering and fruiting. Physiological Plant Pathology, v.17, n.2, p.229-233, 1980.

GUNDLACH, H.; MULLER, M.J.; KUTCHAN, T.M.; ZENK, M.H. Jasmonic acid is a signal transducer in elicitor-induced plant cell cultures. Proceedings of the National Academy of Science of the USA, v.89, n.6, p.2389-2393, 1992.

GUZZO, S.D.; MORAES, W.B.C. Puririficação e caracterização parcial de um elicitor de fitoalexina em soja, a partir de urediniosporos de Hemileia vastatrix. Fitopatologia Brasileira, v.22, n.3, p.396-402, 1997.

HAHN, M. G. Microbial elicitors and their receptors in plants. Annual Review of Phytopathology, v.34, p.387-412, 1996.

HAMMERSCHMIDT, R. Induced disease resistance: how do induced plants stop pathogens? Physiological and Molecular Plant Pathology, v.55, n.2, p.77-84, 1999.

HAMMERSCHMIDT, T.; KUC, J. Lignification as a mechanism for induced systemic resistance in cucumber. Physiological Plant Pathology, v.20, n.1, p.61-71, 1982. 
HATVANI, N. Antibacterial effect of the culture fluid of Lentinus edodes mycelium grown in submerged liquid culture. International Journal of Antimicrobial Agents, v.17, n.1, p.71-74, 2001.

HEINKEL, C.M.; HUDSPETH, M.E.S.; MEGANATHAN, R.; ZINNEM, T.M. Further characterization of mycolaminaran-induced resistance: temperature sensivity against Tobacco mosaic virus and function against Cauliflower mosaic virus and Tomato spotted wilt virus. Phytopathology, v.82, n.6, p.637-641, 1992.

HIRAMATSU, A.; KOBAYASHI, N.; OSAWA, N. Properties of two inhibitors of plant virus infection from fruiting bodies of Lentinus edodes and from leaves of Yucca recurvifolia Salisb. Agricultural and Biological Chemi stry, v.51, n.3, p.897-904, 1987.

HIRASAWA, M.; SHOUJI, N.; NETA, T.; FUKUSHIMA, K.; TAKADA, K. Three kinds of antibacterial substances from Lentinus edodes. International Journal of Antimicrobial Agents, v.11, n.2, p.151-157, 1999.

HOBBS, C. Medicinal mushrooms: an exploration of the tradition, healing and culture. 3.ed. Louveland: Interweare Press, 1996. 251p.

HOLlings, M.; BRUNT, A.A. Potyvirus group. Wallingford: Commonnwealth Mycological Institute and Association of Applied Biologists, 1981. 1v. (Description of Plant Viruses, 245).

INOUE, A.K.; MELLO, R.N.; NAGATA, T.; KITAGIMA, E.W. Characterization of Passion fruit woodiness virus isolates from Brasília and surrounding region, Brazil. Fitopatologia Brasileira, v.20, n.3, p.479-487, 1995. 
ISHII, H.; TOMITA, Y.; HORIO, T.; NARUSAKA, Y.; NAKAZAWA, Y.; NISHIMURA, K.; IWAMOTO, S. Induced resistance of acibenzolar-S-methyl to cucumber and japanese pear diseases. European Journal of Plant Pathology, v.105, n.1, p.77-85, 1999.

JAN, F.J.; YEH, S.D. Purification, in situ localization, and comparative serological properties of passionfruit woodiness virus-encoded amorphous inclusion protein and two other virus proteins. Phytopathology, v.85, n.1, p.64-71, 1995.

JI, C.; KUC, J. Non-host resistance to Colletotrichum lagenarium in pumpkin and squash is not primarily associated with $\beta$-1,3-glucanase and chitinase activities. Physiological and Molecular Plant Pathology, v.50, n.6, p.361-370, 1997.

JI, C.; KUC, J. Purification and characterization of an acidic $\beta$-1,3-glucanase from cucumber and its relationship to systemic disease resistance induced by Colletotrichum lagenarium and Tobacco necrosis virus. Molecular Plant-Microbe Interaction, v.8, n.6, p.899-905, 1995.

JIN, Q.L.; LIU, N.Z.; QIU, J.L.; LI, D.B.; WANG, J. A truncated fragment of harpin Pss induces systemic resistance to Xanthomonas campestris pv. oryzae in rice. Physiological and Molecular Plant Pathology, v.51, n.4, p.243-257, 1997.

JONES, J. Harpin. Pesticide -Outlook, v.12, n.4, p.134-135, 2001.

JONG, S.C.; BIRMINGHAM, J.M. Medicinal and therapeutic value of the shiitake mushroom. Advances in Applied Microbiology, v.39, p.153-184, 1993.

JOOSTEN, M.H.A.J.; DE WIT, P.J.G.M. Identification of several pathogenesis-related proteins in tomato leaves inoculated with Cladosporium fulvum as $\beta$-1,3-glucanases and chitinases. Plant Physiology, v.89, n.3, p.945-951, 1989. 
KADDER, J.C. Lipid-transfer proteins: a puzzling family of plant proteins. Trends in Plant Science, v.2, p.66-70, 1997.

KAWAGISHI, H.; KANAO, T.; INAGAKI, R.; MIZUNO, T.; SHIMURA, K.; ITO, H.; HAGIWARA, T.; NAKAMURA, T. Formolysis of a potent antitumor $(1 \rightarrow 6)-\beta$-Dglucan-protein complex from Agaricus blazei fruiting bodies and antitumor activity of resulting products. Carbohydrate Polymers, v.12, n.4, p.393-403, 1990.

KEEN, N.T.; YOSHIKAWA, M. $\beta-1,3$-endoglucanase from soyabean releases elicitoractive carbohydrates from fungus cell walls. Plant Physiology, v.71, n.3, p.460465, 1983.

KESSMANN, H.; STAUB, T.; HOFMANN, C.; MAETZKE, T.; HERZOG, J. Induction of systemic acquired disease resistance in plants by chemicals. Annual Review of Phytopathology, v.32, p.439-459, 1994.

KOBAYASHI, N.; HIRAMATSU, A.; AKATSUKA, T. Purification and chemical properties of an inhibitor of plant virus infection fom fruiting bodies of Lentinus edodes. Agricultural and Biological Chemistry, v.51, n.3, p.883-890, 1987.

KOMEMUSHI, S.; YAMAMOTO, Y.; FUJTA, T. Purification and identification of antimicrobial substances produced by Lentinus edodes. Journal of Antibacterial and Antifungical Agents, v.24, n.1, p.21-25, 1996.

KOVATS, K.; BINDER, A.; HOHL, H.R. Cytology of induced systemic resistance of cucumber to Colletotrichum lagenarium. Planta, v.183, n.4, p.484-490, 1991. 
KUBOTA, M.; ABIKO, K. Induced resistance in cucumbers against Fusarium oxysporum f. sp. cucumerinum and Rhizoctonia solani AG2-2 by infection of the cotyledons. Journal of Phytopathology, v.149, n.5, p.297-300, 2001.

KUC, J.; RICHMOND, S. Aspects of the protection of cucumber against Colletotrichum lagenarium by Colletotrichum lagenarium. Phytopathology, v.67, n.4, p.533-536, 1977.

KUC, J.; SHOCKLEY, G.; KEARNEY, K. Protection of cucumber against Colletotrichum lagenarium by Colletotrichum lagenarium. Physiological Plant Pathology, v.7, n.2, p.195-199, 1975.

KUROZAWA, C.; PAVAN, M.A. Doenças das cucurbitáceas. In: KIMATI, H.; AMORIM, L.; BERGAMIN FILHO, A.; CAMARGO, L.E.A.; REZENDE, J.A.M. (Ed.). Manual de fitopatologia. 3.ed. São Paulo: Agronômica Ceres, 1997. v.2: Doenças das plantas cultivadas, cap.29, p.325-344.

KUTZNER, B.; HELLWALD, K.H.; BUCHENAUER, H. Systemic induction of resistance in Phaseolus vulgaris L. to Tobacco necrosis virus (TNV) by Uromyces phaseoli Wint. Journal of Phytopathology, v.138, n.1, p.9-20, 1993.

LABANCA, E. R. G. Purificação parcial de elicitores presentes em Sacharomycces cerevisiae: atividade como indutores de resistência em pepino contra Colletotrichum lagenarium e da síntese de gliceolinas em soja. Piracicaba, 2002. 107p. Dissertação (Mestrado) - Escola Superior de Agricultura "Luiz de Queiroz", Universidade de São Paulo.

LAEMMLI, U.K. Cleavage of structural proteins during the assembly of the head of bacteriophage T4. Nature, v.227, n.259, p.680-685, 1970. 
LAFONTAINE, P.J.; BENHAMOU, N. Chitosan treatment: an emerging strategy for enhancing resistance of greenhouse tomato plants to infection by Fusarium oxysporum f. sp. radicis-lycopercisi. Biocontrol Science and Technology, v.6, n.1, p.111-124, 1996.

LAWRENCE, C.B.; JOOSTEN, M.H.A.; TUZUN, S. Differential induction of pathogenesis-related proteins in tomato by Alternaria solani and the association of a basic chitinase isozyme with resistance. Physiological and Molecular Plant Pathology, v.48, n.6, p.361-377, 1996.

LEATHAM, G.F. Growth and development of Lentinus edodes on a chemically defined medium. In: MOORE, D.; CASSELTON, L.A.; WOOD, D.A.; FRANKLAND, J.S. (Ed.). Developmental biology of higher fungi. Cambridge: Cambridge Press, 1985. p.403-427.

LELIK, L.; VITANYI, G.; LEFLER, J.; HEGOCZKY, J.; NAGY-GASZTONYI, M.; VERECZKEY, G. Production of the mycelium of shiitake (Lentinus edodes) mushroom and investigation of its bioactive compounds. Acta Alimentaria, v.26, n.3, p.271-277, 1997.

LEVER, M. A new reaction for colorimetric determination of carbohydrates. Analytical Biochemistry, v.47, n.1, p.273-279, 1972.

LING, K.S.; NAMBA, C.; GONSALVES, C.; SLIGHTOM, J.L.; GONSALVES, D. Protection against detrimental effects of potyvirus infection in transgenic tobacco plants expressing the papaya ringspot virus coat protein gene. Bio/Technology, v.9, n.8, p.752-758, 1991.

LINTHORST, H.J.M. Pathogenesis-related proteins of plants. Critical Reviews in Plant Sciences, v.10, n.2, p.123-150, 1991. 
LOPES, C.A.; SANTOS, J.R.M. dos. Doenças do tomateiro. Brasília:EMBRAPA, CNPH; EMBRAPA, SPI, 1994. 61p.

MAISS, E. Induced resistance in systemic host-virus combinations by culture filtrates of Stachybotrys chartarum. Journal of Phytopathology, v.119, n.2, p.175-183, 1987.

MAKI, C.S. Respostas fungistáticas de Lentinula edodes sobre Candida albicans e análise da variabilidade intraespecífica. Londrina, 1999. 109p. Dissertação (M.S.) Universidade Estadual de Londrina.

MALECK, K.; LAWTON, K. Plant strategies for resistance to pathogens. Current Opnion in Biotechnology, v.9, n.2, p.208-213, 1998.

MAUCH, F.; HADWIGER, L.A.; BOLLER, T. Ethylene - symptom, not signal for the induction of chitinase and beta-1,3-glucanase in pea pods by pathogens and elicitors. Plant Physiology, v.76, n.3, p.607-611, 1984.

McKNIGHT, T. The woodiness virus of the passion vine (Passiflora edulis Sims). Queensland Journal of Agricultural Science, v.10, p.4-35, 1953.

MELLO, S.C.M.; LOPES, C.A.; TAKATSU, A. Avaliação de virulência de isolados de Xanthomonas campestris pv. vesicatoria ao tomateiro. Fitopatologia Brasileira, v.21, p.39-43, 1996.

MENOLI, R.C.R.N.; MANTOVANI, M.S.; RIBEIRO, L.R.; SPEIT, G.; JORDÃO, B.Q. Antimutagenic effects of the mushroom Agaricus blazei extracts on V79 cells. Mutation Research, v.496, n.1/2, p.5-13, 2001. 
MÉTRAUX, J.P. Systemic acquired resistance and salicylic acid: current state of knowledge. European Journal of Plant Pathology, v.107, n.1, p.13-18, 2001.

MÉTRAUX, J.P.; BOLLER, T. Local and systemic induction of chitinase in cucumber plants in response to fungal, bacterial and viral infections. Physiological and Molecular Plant Pathology, v.28, n.2, p.161-169, 1986.

MIYAKOSHI, H.; AOKI, T.; MIZUKOSHI, M. Acting mechanisms of lentinan in human. 2. Enhancement of non-specific cell mediated cyto-toxicity as an interferon inducer. International Journal of Immunopharmacology, v.6, n.4, p.373-379, 1984.

MIZUNO, M.; MINATO, K.; HITOSHI, I.; MITSUO, K.; HIROFUMI, T.; HIRONOBU, T. Anti-tumor polysaccharide from the mycelium of liquid-cultured Agaricus blazei. Biochemistry and Molecular Biology International, v.47, n.4, p.707-714, 1999.

MIZUNO, M.; MORIMOTO, M.; MINATO, K.; TSUCHIDA, H. Polysaccharides from Agaricus blazei stimulate lymphocyte T-cell subsets in mice. Bioscience and Biotechnology Biochemistry, v.62, n.3, p.434-437, 1998.

MIZUNO, T. Bioactive biomolecules of mushrooms: food function and medicinal effect of mushroom fungi. Food Review International, v.11, n.1, p.7-21, 1995a.

MIZUNO, T. Kawariharatake, Agaricus blazei Murril: medicinal and dietary effects. Food Review International, v. 11, n.1, p.167-172, 1995b. 
MIZUNO, T.; HAGIWARA, T.; NAKAMURA, T.; ITO, H.; SHIMURA, K.; SUMIYA, T.; ASAKURA, A. Antitumor activity and some properties of water-soluble polysaccharides from "Himematsutake", the fruiting body of Agaricus blazei Murill. Agricultural and Biological Chemistry, v.54, n.11, p.2889-2896, 1990.

MOLINA, F.I.; SHEN, P.; JONG, S.C.; ORIKONO, K. Molecular evidence supports the separation of Lentinula edodes from Lentinus and related genera. Canadian Journal of Botany, v.70, n.12, p.2446-2452, 1992.

MOORE-LANDECKER, E. Fundamentals of the fungi. 2.ed. Englewood Cliffs:Prentice-Hall, 1982. v.8, 578p.

M'PIGA, P.; BÉLANGER, R.R.; PAULITZ, T.C.; BENHAMOU, N. Increased resistance to Fusarium oxysporum f. sp. radicis-lycopersici in tomato plants treated with the endophytic bacterium Pseudomonas fluorescens strain 63-28. Physiological and Molecular Plant Pathology, v.50, n.5, p.301-320, 1997.

NAKAJIMA, A.; ISHIDA, T.; KOGA, M.; TAKEUCHI, T.; MAZDA, O.; TAKEUCHI, M. Effect of hot water extract from Agaricus blazei Murill on antibody-producing cells in mice. International Immunopharmacology, v.2, n.8, p.1205-1211, 2002.

NOVAES, Q. S. Seleção de estirpes fracas do Passion fruit woodiness virus e tentativas de premunização para o controle do endurecimento dos frutos do maracujazeiro. Piracicaba, 2002. 74p. Tese (Doutorado) - Escola Superior de Agricultura "Luiz de Queiroz”, Universidade de São Paulo.

O'DONNEL, P.J.; CALVERT, C.; ATZORN, R.; WASTERNACK, C.; LEYSER, H.M.O.; BOWLES, D.J. Ethylene as a signal mediating the wound response of tomato plants. Science, v.274, n.5294, p.1914-1917, 1996. 
O'GARRO, L.W. Bacterial spot of tomato and pepper on four East Caribbean islands: races, their abundance, distribution, aggressiveness, and prospects for control. Plant Disease, v.82, n.8, p.864-870, 1998.

OSAKI, Y.; KATO, T.; YAMAMOTO, K.; OKUBO, J.; MIYAZAKI, T. Antimutagenic and bactericidal substances in the fruit body of a basidiomycete Agaricus blazei. Yakugaku Zasshi-Journal of the Pharmaceutical Society of Japan, v.114, n.5, p.342-350, 1994.

OZERETSKOVSKAYA, O. Induced resistance in the solanaceae. In: HAMMERSCHIMIDT, R.; KUC, J. (Ed.). Induced resistance to disease in plants. Boston: Kluwer Academic, 1995. cap.2, p.31-62.

PACCOLA, E.A.S. Estudo do efeito fungistático dos basidiomicetos Lentinula edodes (shiitake) e Agaricus blazei murril (cogumelo-do-sol) sobre Candida albicans. Londrina, 1997. 78p. Monografia (Graduação) - Universidade Estadual de Londrina.

PACUMBABA, R.P; BEYL, C.A.; PACUMBABA, R.O. Shiitake mycelial leachate supresses growth of some bacterial species and symptoms of bacterial wilt of tomato and lima bean in vitro. Plant Disease, v.83, n.1, p.20-23, 1999.

PARKER, J.E.; SCHULTE, W.; HAHLBROCK, K.; SCHEEL, D. An extracellular glycoprotein from Phytophthora megasperma f. sp. glycinea elicits phytoalexin synthesis in cultured parsley cells and protoplasts. Molecular Plant-Microbe Interactions, v.4, n.1, p.19-27, 1991.

PEARCE, R.B.; RIDE, J.P. Chitin and related compounds as elicitors of the lignification response in wounded wheat leaves. Physiological Plant Pathology, v.20, n.1, p.119-123, 1982. 
PENNAZIO, S.; ROGGERO, P. Systemic acquired resistance induced in tobacco plants by localized virus infection does not operate against challenging viruses that infect systemically. Journal of Phytopathology, v.121, n.3, p.255-266, 1988.

PENNINCKX, I.A.M.A.; EGGERMONT, K.; TERRAS, F.R.G.; THOMMA, B.P.H.J.; SAMBLANX, G.W.; BUCHALA, T.; MÉTRAUX, J.P.; MANNERS, J.M.; BROEKAERT, W.F. Pathogen-induced systemic activation of a plant defensin gene in Arabidopsis follows a salicylic acid-independent pathway involving components of the ethylene and jasmonic acid responses. Plant Cell, v.8, n.12, p.2309-2323, 1996.

PICCININ, E. Potencial de preparações do cogumelo comestível shiitake (Lentinula edodes) no controle de fitopatógenos fúngicos, bacterianos e virais em sorgo, maracujá e fumo. Piracicaba, 2000. 162p. Tese (Doutorado) - Escola Superior de Agricultura 'Luiz de Queiroz”, Universidade de São Paulo.

PIETERSE, C.M.J.; VAN WESS, S.C.M.; HOFFLAND, E.; VAN PELT, J.A.; VAN LOON, L.C. Systemic resistance in Arabidopsis induced by biocontrol bacteria is independent of salicylic acid accumulation and pathogenesis-related gene expression. Plant Cell, v.8, n.8, p.1225-1237, 1996.

PIETERSE, C.M.J.; VAN PELT, J.A.; VAN WEES, S.C.M.; TON, J.; LÉONKLOOSTERZIEL, K.M.; KEURENTJES, J.J.B.; VERNHAGEN, B.W.M.; KNOESTER, M.; VAN DER SLUIS, I.; BAKKER, P.A.H.M.; VAN LOON, L.C. Rhizobacteria-mediated induced systemic resistance: triggering, signalling and expression. European Journal of Plant Pathology, v.107, n.1, p.51-61, 2001. 
PIO-RIBEIRO, G.; MARIANO, R.L.R. Doenças do maracujazeiro. In: KIMATI, H.; AMORIM, L.; BERGAMIN FILHO, A.; CAMARGO, L.E.A; REZENDE, J.A.M. (Ed). Manual de fitopatologia. 3.ed. São Paulo: Agronômica Ceres, 1997. v.2: Doenças das plantas cultivadas, cap.50, p.525-534.

PIZA JÚNIOR, C.T. A cultura do maracujá na região sudeste do Brasil. In: SIMPÓSIO BRASILEIRO SOBRE A CULTURA DO MARACUJAZEIRO, Jaboticabal, 1998. Maracujá: do plantio à colheita; anais. Jaboticabal: FUNEP, 1998. p.20-48.

PRAVEEN, S.; TRIPATHI, S.; VARMA, A. Isolation and characterization of an inducer protein (Crip-31) from Clerodendrum inerme leaves responsible for induction of systemic resistance against viruses. Plant Science, v.161, n.3, p.453-459, 2001.

PRZYBYLOWICZ, P.; DONOGHUE, J. Shiitake growers handbook: the art and science of mushroom cultivation. Dubuque: Kendall; Hunt Publ., 1990. 217p.

RAUPACH, G.S.; LIU, L.; MURPHY, J.F.; TUZUN, S.T.; KLOEPPER, J.W. Induced systemic resistance in cucumber and tomato against Cucumber mosaic cucumovirus using plant growth-promoting rhizobacteria. Plant Disease, v.80, n.8, p.891-894, 1996.

REN, Y.Y.; WEST, C.A. Elicitation of diterpene biosynthesis in rice (Oryza sativa L.) by chitin. Plant Physiology, v.99, n.3, p.1169-1178, 1992.

REUVENI, M.; AGAPOV, V.; REUVENI, R. A foliar spray of micronutrient solutions induces local and systemic protection against powdery mildew (Sphaerotheca fuliginia) in cucumber plants. European Journal of Plant Pathology, v.103, n.7, p.581-588, 1997. 
REZENDE, J.A.M. Doenças de vírus e micoplasma do maracujazeiro no Brasil. In: SÃO JOSÉ, A.R. (Ed). Maracujá: produção e mercado. Vitória da Conquista:UESB, 1994. p.116-125.

RICCI, P.; TRENTIN, F.; BONNET, P.; VENARD, P.; MOUTON-PERRONNET, F.; BRUNETEAU, M. Differential production of parasiticien, an elicitor of necrosis and resistance in tobacco, by isolates of Phytophthora parasitica. Plant Pathology, v.41, n.3, p.298-307, 1992.

ROMERO, A.M.; KOUSIK, C.S; RITCHIE, D.F. Resistance to bacterial spot in bell pepper induced by acibenzolar-S-methyl. Plant Disease, v.85, n.2, p.189-194, 2001.

RYALS, J.; NEUENSCHWANDER, U.; WILLITS, M.G.; MOLINA, A.; STEINER, H.Y.; HUNT, M.D. Systemic acquired resistance. Plant Cell, v.8, n.10, p.1809$1819,1996$.

SACKS, W.; NURNBERGER, T.; HAHLBROCK, K.; SCHEEL, D. Molecular characterization of nucleotide sequences encoding the extracellular glycoprotein elicitor from Phytophthora megasperma. Molecular and General Genetics, v.246, n.1, p.45-55, 1995.

SASAKI, S.H. Protoplastização de Lentinula edodes e seu antagonismo sobre o vírus VSA e sobre fungos filamentosos. Londrina, 1997. 69p. Dissertação (M.S.) Universidade Estadual de Londrina.

SATHIYABAMA, M.; BALASUBRAMANIAN, R. Chitosan induces resistance components in Arachis hypogaea against leaf rust caused by Puccinia arachidis. Crop Protection, v.17, n.4, p.307-313, 1998. 
SCHAFFRATH, U.; SCHEINPFLUG, H.; REISENER, H.J. An elicitor from Pyricularia oryzae induces resistance responses in rice: isolation, characterization and physiological properties. Physiological and Molecular Plant Pathology, v.46, n.4, p.293-307, 1995.

SCHNEIDER, S.; ULLRICH, W.R. Differential induction of resistance and enhanced enzyme activities in cucumber and tobacco caused by treatment with various abiotic and biotic inducers. Physiological and Molecular Plant Pathology, v.45, n.4, p.291-304, 1994.

SORIMACHI, K.; IKEHARA, Y.; MAEZATO, G.; OKUBO, A.; YAMAZAKI, S.; AKIMOTO, K.; NIWA, A. Inhibition by Agaricus blazei Murrill fractions of cytopathic effect induced by Western equine encephalitis virus on VERO cells in vitro. Bioscience and Biotechnology Biochemistry, v.65, n.7, p.1645-1647, 2001.

STAUB, T.; KUC, J. Systemic protection of cucumber plants against diseases caused by Cladosporium cucumerinum and Colletotrichum lagenarium by prior localized infection with either fungus. Physiological Plant Pathology, v.17, n.3, p.389-393, 1980.

STEIN, B.D.; KLOMPARENS, K.; HAMMERSCHMIDT, R. Histochemistry and ultraestructure of the induced resistance response of cucumber plants to Colletotrichum lagenarium. Journal of Phytopathology, v.137, n.3, p.177-188, 1993.

STICHER, L.; MAUCH-MANI, B.; MÉTRAUX, J.P. Systemic acquired resistance. Annual Review of Phytopathology, v.35, p.235-270, 1997. 
SUGANO, N.; HIBINO, Y.; CHOJI, Y.; MAEDA, H. Anticarcinogenic actions of water-soluble and alcohol insoluble fractions from culture medium of Lentinus edodes mycelia. Cancer Letters, v.17, n.2, p.109-114, 1982.

SUGIYAMA, K.; AKACHI, T.; YAMAKAWA, A. A hypocholesterolemic action of eritadenine is mediated by a modification of hepatic phospholipid metabolism in rats. Journal of Nutrition, v.125, n.8, p.2134-2144, 1995.

SULE, S. Induced resistance in tomato against Corynebacterium michiganense pv. michiganense by prior inoculation with Pseudomonas syringae pathovars. Phytopathology, v.122, n.4, p.343-350, 1988.

SUTULA, C.L.; GILLETT, J.M.; MORRISSEY, S.M.; RAMSDELL, D.C. Interpreting ELISA data and establishing the positive-negative threshold. Plant Disease, v.70, n.8, p.722-726, 1986.

SUZUKI, F.; SUZUKI, C.; SHIMOMURA, E.; MAEDA, H.; FUJI, T.; ISHIDA, N. Antiviral and interferon-inducing activities of a new peptidomannan, KS-2, extracted from culture mycelia of Lentinus edodes. Journal of Antibiotics, v.32, n.12, p.1336-1345, 1979.

SUZUKI, H.; IIYAMA, K.; YOSHIDA, O.; YAMAZAKI, S.; YAMAMOTO, N.; TODA, S. Structural characterization of the immunoactive and antiviral watersolubilized lignin in an extract of the culture medium of Lentinus edodes mycelia (LEM). Agricultural and Biological Chemistry, v.54, n.2, p.479-487, 1990.

SUZUKI, S.; OHSHIMA, S. Influence of shiitake (Lentinus edodes) on human serum cholesterol. Mushroom Science, v.9, p.463-467, 1974. 
TAKAKU, T.; KIMURA, Y.; OKUDA, H. Isolation of an antitumor compound from Agaricus blazei Murill and its mechanism of action. Journal of Nutrition, v.131, n.5, p.1409-1413, 2001.

TAMIETTI, G.; FERRARIS, L.; MATTA, A.; GENTILE, A. Physiological responses of tomato plants grown in Fusarium suppressive soil. Journal of Phytopathology, v.138, n.1, p.66-76, 1993.

TAYLOR, R.H.; GREBER, R.S. Passion fruit woodiness virus. Wallingford: Commonnwealth Mycological Institute and Association of Applied Biologists, 1973. 1v. (Description of Plant Viruses, 122).

TEIXEIRA, E. M. Caracterização isoenzimática e molecular de Lentinula edodes e avaliação da produção em função da espécie de eucalipto e clima. Araraquara, 2000. 123p. Tese (Doutorado) - Instituto de Química, Universidade Estadual Paulista.

THOMPSON, D.C.; JENKINS, S.F. Pictorial assessment key to determine fungicide concentrations that control anthracnose development on cucumber cultivars with varying resistance levels. Plant Disease, v.69, p.833-836, 1985.

TOCHIKURA, T.S.; NAKASHIMA, H.; OHASHI, Y.; YAMAMOTO, N. Inhibition (in vitro) of replication and of the cytopathic effect of human immunodeficiency virus by an extract of the culture medium of Lentinus edodes mycelia. Medical Microbiology and Immunology, v.177, n.5, p.235-244, 1988.

TUZUN, S.; JUAREZ, J.; NESMITH, W.C.; KUC, J. Induction of systemic resistance in tobacco against metalaxyl-tolerant strains of Peronospora tabacina and the natural occurrence of the phenomenon in Mexico. Phytopathology, v.82, n.4, p.425-429, 1992. 
VANCE, C.P.; KIRK, T.K.; SHERWOOD, R.T. Lignification as a mechanism of disease resistance. Annual Review of Phytopathology, v.18, p.259-288, 1980.

VAN LOON, L.C. Induced resistance in plants and the role of pathogenesis-related proteins. European Journal of Plant Pathology, v.103, n.9, p.753-765, 1997.

VAN LOON, L.C.; VAN KAMMEN, A. Polyacrylamide disc electrophoresis of the soluble leaf proteins form Nicotiana tabacum var. "Samsun" and "Samsun NN". Virology, v.40, n.2, p.199-211, 1970.

VAN LOON, L.C.; BAKKER, P.A.H.; PIETERSE, C.M.J. Systemic resistance induced by rhizosphere bacteria. Annual Review of Phytopathology, v.36, p.453-483, 1998.

VAN LOON, L.C.; PIERPOINT, W.S.; BOLLER, T.; CONEJERO, V. Recommendations for naming plant pathogenesis-related proteins. Plant Molecular Biology Reporter, v.12, p.245-264, 1994.

VAN NIEUWENHUIJZEN, B. Quality: keyword for the mushroom industry. Mushroom Journal, v.579, p.13-19, 1998.

VAN PEER, R.; SCHIPPERS, B. Lipopolysaccharides of plant-growth promoting Pseudomonas sp. strain WCS417r induce resistance in carnation to fusarium wilt. Netherland Journal of Plant Pathology, v.98, n.2, p.129-139, 1992.

VAN PEER, R.; NIEMANN, G.J.; SCHIPPERS, B. Induced resistance and phytoalexin accumulation in biological control of fusarium wilt of carnation by Pseudomonas sp. strain WCS417r. Phytopathology, v.81, n.7, p.728-734, 1991. 
VAN WEES, S.C.M.; DE SWART, E.A.M.; VAN PELT, J.A.; VAN LOON, L.C.; PIETERSE, C.M.J. Enhancement of induced disease resistance by simultaneous activation of salicylate- and jasmonate-dependent defense pathways in Arabidopsis thaliana. Proceedings of the National Academy of Science of the USA, v.97, n.15, p.8711-8716, 2000.

VAN WEES, S.C.M.; PIETERSE, C.M.J.; TRIJSSENAAR, A.; VAN'T WESTENDE, Y.A.M.; HARTOG, F.; VAN LOON, L.C. Differential induction of systemic resistance in Arabidopsis by biocontrol bacteria. Molecular Plant-Microbe Interactions, v.10, n.6, p.716-724, 1997.

VAUTERIN, L.; HOSTE, B.; KERSTERS, K.; SWINGS, J. Reclassification of Xanthomonas. International Journal of Systematic Bacteriology, v.45, n.3, p.472-489, 1995.

VERMA, H.N.; SRIVASTAVA, S.; KUMAR, D. Induction of systemic resistance in plants against viruses by a basic protein from Clerodendrum aculeatum leaves. Phytopathology, v.86, n.5, p.485-492, 1996.

VERNOOIJ, B.; FRIEDRICH, L.; MORSE, A.; REIST, R.; KOLDITZ JAWHAR, R.; WARD, E.; UKNES, S.; KESSMANN, H.; RYALS, J. Salicylic acid is not the translocated signal responsible for inducing systemic acquired resistance but it is required in signal transduction. Plant Cell, v.6, n.7, p. 959-965, 1994.

WARD, E.R.; UKNES, S.J.; WILLIAMS, S.C.; DINCHER, S.S.; WIEDERHOLD, D.L.; ALEXANDER, D.C.; AHL-GOY, P.; MÉTRAUX, J.P.; RYALS, J.A. Coordinate gene activity in response to agents that induce systemic acquired resistance. Plant Cell, v. 3, n.10, p.1085-1094, 1991. 
WASSER, S.P.; WEIS, A.L. Therapeutic effects of substances occurring in higher basidiomycetes mushrooms: a modern perspective. Critical Reviews in Immunology, v.19, n.1, p.65-96, 1999.

WEI, G.; KLOEPPER, J.W.; TUZUN, S. Induced systemic resistance to cucumber diseases and increased plant growth by plant growth-promoting rhizobacteria under field conditions. Phytopathology, v.86, n.2, p.221-224, 1996.

WEI, Z.M.; BEER, S.V.; BONN, W.G. Harpin from Erwinia amylovora induces plant resistance. Acta Horticulturae, n.411, p.223-225, 1996.

WEI, Z.M.; LABY, R.J.; ZUMOFF, C.H.; BAUER, D.W.; HE, S.Y.; COLLMER, A.; BEER, S.V. Harpin, elicitor of the hypersensitive response produced by the plant pathogen Erwinia amylovora. Science, v.257, n.5066, p.85-88, 1992.

WIRTH, S.J.; WOLF, G.A. Dye-labelled substrates for the assay and detection of chitinase and lysozyme activity. Journal of Microbiological Methods, v.12, n.(34), p.197-205, 1990.

WULFF, N.A.; PASCHOLATI, S.F. Partial characterization of sorghum phytoalexin elicitors isolated from Saccharomyces cerevisiae. Fitopatologia Brasileira, v.24, n.3, p.428-435, 1999.

YE, X.S.; PAN, S.Q.; KUC, J. Pathogenesis-related proteins and systemic resistance to blue mold and Tobacco mosaic virus induced by Tobacco mosaic virus, Peronospora tabacina and aspirin. Physiological and Molecular Plant Pathology, v.35, n.2, p.161-175, 1989. 
YE, X.S.; JARLFORS, U.; TUZUN, S.; PAN, S.Q.; KUC, J. Biochemical changes in cell walls and cellular responses of tobacco leaves related in systemic resistance to blue mold induced by tobacco mosaic virus. Canadian Journal of Botany, v.70, n.1, p.49-57, 1992.

YEH, S.D.; CHU, F.H. Production and evaluation of transgenic tobacco plants expressing the coat protein gene of passionfruit woodiness virus. Botanical Bulletin of Academic Science, v.37, n.3, p.181-190, 1996.

YOSHIKAWA, M.; TSUDA, M.; TAKEUCHI, Y. Resistance to fungal disease in transgenic tobacco plants expressing the phytoalexin elicitor-releasing factor, $\beta$-1,3endoglucanase, from soybean. Natur-wissenschaften, v.80, n.9, p.417-420, 1993.

ZHANG, Y.; FAN, W.; KINKEMA, M.; LI, X.; DONG, X. Interaction of NPR1 with basic leucine zipper protein transcription factors that bind sequences required for salicylic acid induction of the PR-1 gene. Proceedings of the National Academy of Sciences of the USA, v.96, n.11, p.6523-6528, 1999.

ZINNEN, T.M.; HEINKEL, C.M.; HUDPETH, M.E.S.; MEGANATHAN, R. The role of citoplasmic mycolaminaran in inhibiting initial viral infection of certain Nicotiana species. Phytopatology, v.81, n.4, p.426-428, 1991. 